JULIo CESAR LAZZARINI LEMOS

\title{
A PROPRIEDADE FUNDIÁRIA ARCAICA: NOVA INTERPRETAÇÃO DA REGRA DO USUS AUCTORITAS FUNDI DA LEI DAS XII TÁBUAS
}

Tese de Doutorado realizada sob a orientação do Prof. Titular EDUARDo CÉSAR SILVEIRA VITA MARCHI, Departamento de Direito Civil - Área de Direito Romano da Faculdade de Direito da Universidade de São Paulo.

\author{
SÃo PAULO
}

fevereiro de 2011 


\section{SUMÁRIO}

Introdução 3

1. A auctoritas decenviral: pressupostos 8

1.1 Excurso histórico sobre as condições de possibilidade fática da evicção no período decenviral

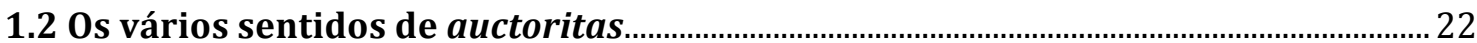

1.3 A denominação auctoritas rerum ou simplesmente auctoritas ................................... 25

1.4 Teorias sobre a extensão e a compreensão do conceito de auctoritas ....................... 26

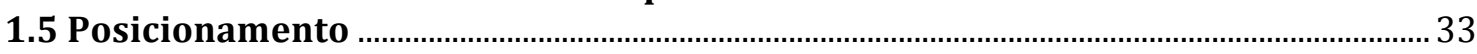

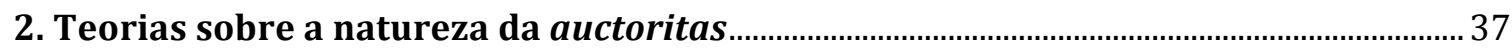

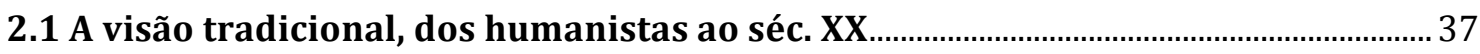

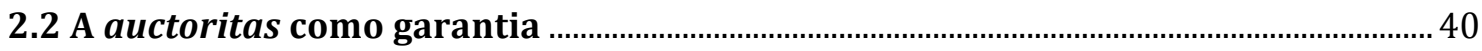

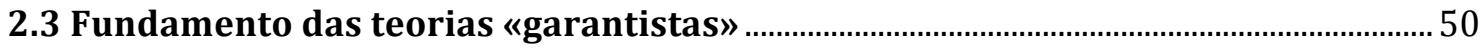

2.4 Críticas e alternativas à teoria tradicional da auctoritas como garantia ................ 65

3. Elementos para a interpretação da regra do usus auctoritas no direito decenviral

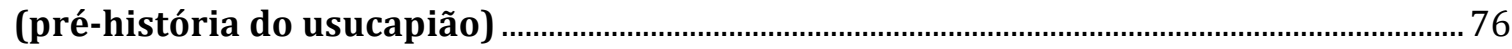

3.1 As terras objeto do usus decenviral. Contexto histórico do adágio usus auctoritas

77

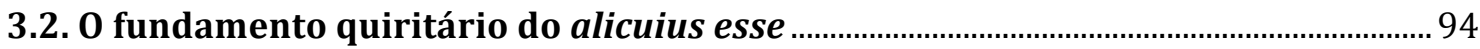

3.3 A antiga ordem augural de delimitação do solo (limitatio). A figura do auctor divisionis et adsignationis e seu antecessor arcaico ........................................................... 112

3.4 Limitatio e propriedade quiritária, fundus-participação e modus agri, usucapio pro herede: mais elementos para a interpretação da regra do usus auctoritas............ 133

3.5. Exegese das fontes da auctoritas decenviral.................................................................. 153

4. Hipótese sobre a interpretação original da regra do usus auctoritas e seu contexto

4.1 Considerações preliminares.

4.2 1. - Fase - O sistema pré-cívico comunitário do Hufenverfassung............................. 179

4.32. a Fase - Na era cívica: sistema de limitação augural................................................... 183

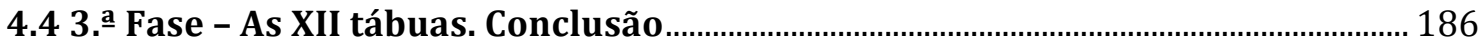

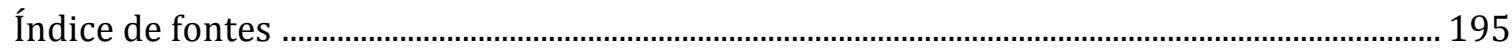

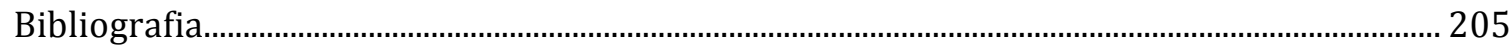

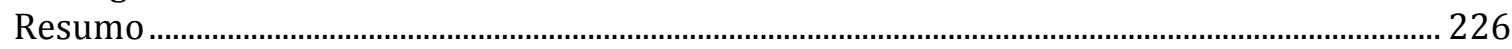

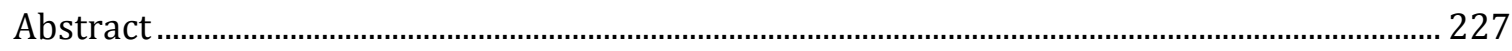

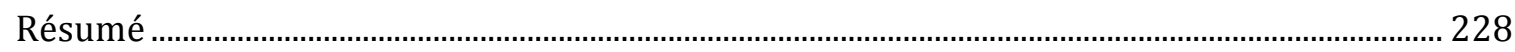




\section{Introdução}

O usacapião - e desde já fica registrada nossa opção, neste trabalho, pelo gênero masculino $-{ }^{1}$ está entre os institutos mais tipicamente romanos que (até) hoje compõem nosso sofisticado direito civil. Se é certo que figuras muito semelhantes já integravam direitos mais antigos, como o assírio e possivelmente o judaico, o usucapião romano, em especial o arcaico, permanece um caso peculiar, para não dizer idiossincrático.

Desde o início, o interesse deste trabalho foi encontrar uma interpretação autêntica, se possível exata, aos olhos da historiografia e da dogmática disponível, de uma antiga regra das XII tábuas que até hoje desafia os mais agudos espíritos: usus auctoritas fundi biennium [esto]. Como parte importante da doutrina, no século $X X$, assumiu cuidar o fragmento de uma norma sobre a garantia prestada pelo alienante, em venda formal (mancipatio), contra evicção, fez-se necessário esgotar, e analisar, a literatura gigantesca que se acumulou sobre o tema - até que seus fundamentos pudessem ser, crê-se modestamente, desmontados.

Isso certamente não teria sido possível, não tivesse parte qualitativamente considerável da doutrina divergido e inaugurado muitas vias novas. Só depois sentiu-se o pesquisador autorizado a, seguindo as pistas deixadas por Cícero e Gaio e por juristas modernos como F. LeIfER, O. BeHRENDS, P. FuenteseCA, R. YARON e A. MAGDELAIN, ensaiar uma reconstrução do preceito de acordo com a penetrante literatura jurídica, arqueológica, histórica propriamente dita, filológica e lingüística disponível até o ano de 2010.

O Código Civil atual, repetindo o de 1916, prevê que quem aliena uma coisa por contrato oneroso responde ipso facto pela eviç̧ão (art. 447).

\footnotetext{
${ }^{1}$ Trata-se de um substantivo de dois gêneros; cf. v. «usucapião» no Aulete Digital, ver. 1.0.
} 
A responsabilidade pela evicção, com efeito, é traço antiqüíssimo do direito privado. A grande maioria dos manuais de direito privado romano ${ }^{2}$ se apóia na teoria, amplamente difundida, de que ela remonta à mencionada disposição das XII tábuas, do séc. V a.C., conservada por Cícero (usus auctoritas fundi biennium [esto]), que seria o fundamento legal da responsabilidade por auctoritas e da correspondente actio auctoritatis.

A ligação entre esse preceito - cujo núcleo é o enigmático termo auctoritas - e a garantia pela eviçcão permanece visível até hoje na doutrina e na legislação. A exemplo disso, o instrumento processual destinado a chamar o alienante (chamado auctor ou garantidor, Gewährsmann, na tese alemã dominante sobre a auctoritas) à ação movida pelo suposto proprietário contra o adquirente em caso de eviç̧ão era denominado, no nosso Código de Processo Civil de 1939, «chamamento à autoria», ${ }^{3}$ uma tradução da expressão auctorem laudare, ${ }^{4}$ nome do procedimento análogo supostamente presente na actio auctoritatis romana.

Já F. C. PONTES DE MIRANDA afirmava que «o conceito de auctoritas está à base do princípio da responsabilidade pela evicção». ${ }^{5}$ Recentemente, $\mathrm{R}$. ZIMMERMANN, um autor conhecido por buscar a integração da tradição romano-

\footnotetext{
${ }^{2}$ Apenas a título de exemplo, cf. alguns entre os mais autorizados: Th. MAYER-MALY, Römisches Recht, 2. ${ }^{\text {a }}$ ed., Wien-New York, Springer, 1999, p. 140; W. KUNKEL;T. MAYER-MALY, Römisches Recht, 4. ${ }^{a}$ ed., Berlin-Heidelberg, Springer, 1987, p. 173; M. KASER, Das römische Privatrecht I - Das altrömische, das vorklassische und klassische Recht, 2.a ed., München, Beck, 1971, p. 39; M. TALAMANCA, Istituzioni di diritto romano, Milano, Giuffrè, 1990, p. 589; S. DI MARZO, Istituzioni di diritto romano, Milano, Giuffrè, 1945, p. 200; W. W. BuCKLAND, A Text-Book of Roman Law: From Augustus to Justinian, Cambridge, 2007, p. 241-242; G. MAY, Éléments de droit romain, 18. ${ }^{a}$ ed., Paris, R. Sirey, 1932, p. 346; A. D'ORS, Elementos de derecho privado romano, Pamplona, Navarra, 1960, p. 354. Cf., entre nós, S. MEIRA, Instituições de Direito Romano, 2. ${ }^{a}$ ed., São Paulo, Max Limonad, s/d, p. 347; A. CORRÊA, G. SCIASCIA, Manual de Direito Romano, 6. ${ }^{a}$ ed., São Paulo, RT, 1988, p. 199; J. C. MoREIRA AlVES, Direito Romano II, 6. ${ }^{a}$ ed., Rio de Janeiro, Forense, 1998, p. 162.

${ }^{3}$ Só em 1973, com a vigência do atual Código de Processo Civil, esse procedimento passou a ser denominado "denunciação da lide», embora substancialmente não tenha mudado, permanecendo semelhante, se damos crédito à descrição dos romanistas, ao procedimento da laudatio auctoris no interior da actio auctoritatis. Também a nova nomeação à autoria não deixa de ser laudatio auctoris.

${ }^{4}$ F. C. Pontes de MiRAndA, Comentários ao Código de Processo Civil II - Arts. 46-153, 2.a ed., Rio de Janeiro, Forense, 1974, p. 104: "O caso do art. 62 [do CPC de 1973] é de nominatio auctoris ou laudatio auctoris». Da mesma linguagem romanista fazem uso as Ordenações Afonsinas (L. IV, Tit. $59, \S 1)$.

${ }^{5}$ Tratado de Direito Privado XXXVIII - Parte especial - Direito das obrigações: Negócios jurídicos bilaterais e negócios jurídicos plurilaterais. Pressupostos. Vícios de direito. Evicção. Redibição. Espécies de negócios jurídicos bilaterais e de negócios jurídicos plurilaterais, $3 .^{a}$ ed., Rio de Janeiro, Borsoi, 1972, p. 158.
} 
civilística (civilian tradition) a fim de fornecer soluções para a crise do direito europeu, traçou a origem do tratamento dado à evicção nos modernos sistemas de direito civil à auctoritas decenviral. ${ }^{6}$

Essa fundamentação, mais dogmática que propriamente histórica, como veremos, parece ter-se incorporado definitivamente ao direito privado, algo bastante evidente na pandectística (auctoritas-Haftung como precedente e fundamento da moderna Eviktionhaftung) ${ }^{7}$

O primeiro a defendê-la ostensivamente teria sido Cujácio, embora o debate científico tenha sido aberto por HUSCHKE e MOMMSEN, culminando em GIRARD.

Todavia, já estiveram em voga outras teses sobre a auctoritas. Alguns autores antigos, como Budé e Alciat, pretenderam atribuir-lhe o sentido de propriedade, posse ou usucapião (a «tese humanista»); outros procuraram um conceito por assim dizer metajurídico de auctoritas, que teria várias aplicações, entre eles o de garantia por eviç̧ão. Esta última tese vem ganhando, atualmente, alguns adeptos.

Com a publicação de um artigo de M. SARGENTI, nos anos 60 do século passado $^{8}$ - abrindo largo espaço de discussão para um tema que estava a ponto de se tornar encerrado, embora ainda controverso - alguns juristas, como F. J. CASINOSMORA, passaram a questionar até mesmo a existência de um mecanismo de garantia contra a evicção no tempo das XII tábuas (em especial a sua concretização numa hipotética, porque carente de fontes, actio auctoritatis).

\footnotetext{
${ }^{6}$ The Law of Obligations: Roman Foundations of the Civilian Tradition, London, Clarendon, 1996, pp. 293-294. Segundo ele, em toda a tradição do direito civil, a situação de quem viu frustradas as suas expectativas após a conclusão de um contrato oneroso em razão de vícios ocultos ou de evicção sempre recebeu um particular tratamento jurídico. A primeira manifestação desse cuidado, nessa tradição, teria sido a responsabilidade com base na auctoritas, de natureza delitual e ligada à mancipatio. Uma visão semelhante, aplicada ao direito holandês, pode ser encontrada em R. FEENSTRA, Romeinsrechtelijke grondslagen van het Nederlands privaatrecht: inleidende hoofdstukken, Amsterdan, Brill, 1990, pp. 51-53, em especial p. 52, em que o autor afirma que a auctoritas representa a origem mais remota dos atuais conceitos de domínio, usucapião e responsabilidade pela evicção na esfera do direito holandês.

${ }^{7}$ W. ERNST, Rechtsmängelhaftung, Tübingen, Mohr, 1995, p. 7, nt. 2, indo mais longe, chega a ligar a actio auctoritatis, suposta ação com o objetivo de tornar efetiva a auctoritas-Haftung, ao dever de restituição da coisa alienada por non dominus previsto no $\S 816,1$, 1, do BGB.

${ }^{8}$ SARgEntI, Manlio, Per una revisione della nozione dell'auctoritas come effetto della mancipatio, in Studi in onore di Emilio Betti IV, Milano, Giuffrè, 1962.
} 
Sabe-se que a venda era feita nos períodos pré-decenviral e decenviral através dos negócios librais, per aes et libram, especialmente pelas mancipationes. Ora, se a mancipatio não trazia consigo, ao menos à época das XII tábuas, um mecanismo de proteção contra a evicção, carecem de base as teorias «garantistas», como as chamaremos a partir de agora, sobre a auctoritas.

Surgem, portanto, duas questões interdependentes: (i) existia a proteção contra evicção, ao menos sob a forma de responsabilidade do alienante pela venda a non domino, no período pré-decenviral e decenviral? (ii) se existia, é correto associar a essa proteção o mecanismo da auctoritas e da actio auctoritatis, tal como formulados pela doutrina "garantista» e, em menor monta, pelas demais teorias?

Uma resposta negativa a essa primeira questão implica à primeira vista a refutação da noção tradicional defendida especialmente a partir do séc. XIX, com as formulações de G. HuschKE, Th. MommSEN e P. F. GIRARD, bem como de todas as teorias construídas a partir desse pressusposto, inclusive a reconstrução de O. LENEL de uma rubrica no edictum perpetuum intitulada De auctoritate, apoiada num árduo trabalho de crítica interpolacionística sobre o Digesto.

A única alternativa que consideramos - diante dos resultados do presente trabalho -, no entanto, é salvar em parte as teorias garantistas, considerando-as como uma descrição da vigência posterior, clássica, da norma decenviral. Desse ponto não nos ocuparemos em nossa pesquisa.

Outra possibilidade, que não exclui a anterior, será manter o sentido de propriedade ou usucapião para a norma decenviral, aderindo, ao menos em parte, à teoria humanista, que mantém a tradição iniciada pela exegese de Cícero e Gaio, fato que muitas vezes tem escapado à percepção dos romanistas.

Diante disso, propomos-nos a pesquisar, no capítulo 1, a literatura que se produziu sobre a compreensão e extensão do conceito da auctoritas, a fim de procurar as bases da analogia entre ela e as outras outras ocorrências do termo em fontes que se reportam à época da lei das XII tábuas, ou que se refiram a ela: auctoritas tutoris e auctoritas patrum, bem como de períodos posteriores -, 
afirmando ou negando à auctoritas supostamente ligada à mancipatio o status de termo técnico-jurídico dissociado das outras noções.

De posse desse pressuposto conceitual, investigaremos no capítulo 2 as teorias "garantistas» e as alternativas a ela, bem como os seus fundamentos, especialmente no que diz respeito às fontes, das quais faremos uma exegese no capítulo seguinte.

É nesse momento - no capítulo 3 - que nossa pequena contribuição terá lugar. Formulamos nele as bases de uma nova teoria sobre a significação da auctoritas no preceito decenviral no contexto arcaico; os resultados serão sumarizados e expostos de forma analítica e cronológica - com definições e conclusões - no capítulo 4. 


\section{A auctoritas decenviral: pressupostos}

\subsection{Excurso histórico sobre as condições de} possibilidade fática da evicção no período decenviral

Todas as teorias que sustentam ter a auctoritas mencionada nas XII tábuas (III, 7; e VI, 3) o sentido de garantia contra a perda da coisa transferida por mancipatio ou por outro modo - decorrente de venda a non domino -, pressupõem a certeza de que esse problema se apresentasse na vida romana no momento em que essa lei foi instituída.

A questão foi formulada explicitamente por F. J. CASINOS-MORA, muito recentemente, numa das poucas monografias escritas sobre o tema da auctoritas. ${ }^{9}$

Segundo ele, o direito decenviral é fragmentário, e portanto seletivo, não exaustivo: ele regularia apenas alguns aspectos importantes da vida romana, surgindo como complementação da tradição consuetudinária. Como conseqüência disso, situações hipotéticas ou casos que dificilmente poderiam ocorrer na vida diária não poderiam ter sido objeto dessa lei. Soma-se a isso o fato de que Roma, no século $V$ a.C., ocupa um estrito marco geográfico e estaria composta de um exíguo número de famílias.

O autor então conclui que é pouco verossímil que um caso que raramente acontecia na vida jurídica corrente tenha sido objeto de uma disposição da lei das XII tábuas; esse seria o caso da venda a non domino e da conseqüente responsabilidade por eviç̧ão. Além disso, a mancipatio, pelo seu caráter formal e solene, já representaria uma garantia suficiente. ${ }^{10}$

Fundado nessa conclusão, o autor afirma que «adolecen de alta improbabilidad» aquelas interpretações do termo auctoritas decenviral que a

\footnotetext{
${ }^{9}$ La noción romana de auctoritas y la responsabilidad por auctoritas, Granada, Comares, 2000, pp. 98-102.

${ }^{10}$ Idem, p. 98-102. Em outras palavras, para esse autor carece de base histórica a afirmação de que em Roma já existia, no séc. $V$ a.C., uma consciência jurídica a respeito do problema da venda de coisa alheia e, implicado nele, uma idéia depurada da responsabilidade por evicção (p. 102).
} 
vinculam à mancipatio e a relacionam à evicção - as quais examinaremos e refutaremos mais tarde. Adiantamos que a conclusão de que a auctoritas decenviral não está vinculada à mancipatio e à garantia pela evicção é correta, ${ }^{11}$ mas a simples pesquisa do contexto histórico (especialmente econômico), como veremos a seguir, não permite refutar as teses "garantistas».

Esse argumento nunca havia sido seriamente discutido pela romanística. A teoria de GIRARD e MOMMSEN, compartilhada por LENEL $^{12}$ - que avançou a partir de uma longa tradição, que remonta pelo menos a CuJÁcıo, que ao contrário de BUDÉ e ALCIATUS sustentava o caráter "garantista» da auctoritas - bem como a dos romanistas do séc. XX que trataram do tema, como veremos, sequer consideram essa possibilidade. A quase unanimidade da doutrina simplesmente presumiu, bem ou mal, a existência de um mecanismo decenviral de proteção do mancipio accipiens em caso de venda de coisa alheia.

Essa presunção basea-se na verossimilhança; o estudo do contexto histórico não faz parte do núcleo da investigação jurídica. Cremos, entretanto, que, surgido o problema, é necessário que se dê elementos para que a dúvida seja desfeita.

Para nós, os argumentos de CASINOS-MORA parecem insatisfatórios, pelos seguintes motivos: a) os direitos do mundo arcaico, anteriores ou contemporâneos do romano, quase sempre regularam, não só na praxis contratual, através de disposições privadas, mas também através de prescrições legais casuísticas, a venda de coisa alheia e a responsabilidade por evicção; b) na Roma do séc. $V$ a.C. é bastante provável que fosse comum o caso da venda de coisa alheia, já que isso acontecia entre os gregos da mesma época; c) é errônea a visão tradicional que considera primitiva a economia e o direito no período decenviral (inícios da República).

A título de comparação, vejamos alguns exemplos do direito arcaico não-romano, a demonstrar a recorrência do fenômeno da evicção em sociedades e

\footnotetext{
${ }^{11} \mathrm{~V}$. o capítulo 4.

${ }^{12}$ É de se notar que GIRARD e LENEL, ao lado de BONFANTE, estão entre os maiores estudiosos da lei das XII tábuas.
} 
economias relativamente primitivas. Com efeito, a investigação das ordens jurídicas mais antigas, como veremos a seguir, coincide com a descoberta de contratos envolvendo cláusulas bastante específicas, como a de proteção contra a evicção.

Começaremos com alguns exemplos da literatura do início do séc. XX, para então recorrer, brevemente, aos estudos atuais de G. PFEIFER. ${ }^{13}$

A exemplo disso, a venda de coisa alheia era um fato comum e regulado pelo «direito» na cidade Susa, ${ }^{14}$ próxima ao rio Tigre, fundada possivelmente em torno de 4.000 a.C. Trata-se do chamado "direito elamita», estudado por assiriologistas e até por romanistas conhecidos, como E. CUQ ${ }^{15}$ e P. KOSCHAKER, ${ }^{16}$ o criador do termo «Keilschriftrecht», ${ }^{17}$ e por historiadores do direito. ${ }^{18}$

Tabuletas descobertas nesta cidade, datando de aproximadamente 2000 a.C., publicadas por V. SCHEIL no início do século passado, ${ }^{19}$ provam, com segurança, o cuidado que tinham os compradores de exigir que os vendedores respondessem pela evicção, num contexto histórico-legal ${ }^{20}$ semelhante ao de Roma

\footnotetext{
${ }^{13} \mathrm{~V}$. adiante a citação do trabalho.

${ }^{14}$ Sobre o sítio geográfico no momento das descobertas, v. G. LONG, Miscelaneous, I. On the site of Susa, in Journal of the Royal Geographical Society of London 3 (1833), pp. 257-267.

${ }^{15} \mathrm{~V}$. Le droit élamite d'après les actes juridiques de Susa, in Revue d'assirologie et d'archeologie orientale 29 (1932), p. 152.

${ }^{16}$ V. por exemplo Göttliches und weltliches Recht nach den Urkunden aus Susa, in Orientalia 4 (1935), p. 44.

${ }_{17}$ Cf. P. KosCHAKER, Keilschriftrecht, in Zeitschrift der Deutschen Morgenländischen Gesellschaft 89 (1935), p. 26; e Forschungen und Ergebnisse in den keilschriftlichen Rechtsquellen, in SZ 49 (1929), pp. 188-189; também utiliza o termo V. KOROSEC, Keilschriftrecht, Leiden, E. J. Brill, 1964, incluído em B. SPULER (org.), Handbuch der Orientalistik, vol. $1^{3}$ - Orientalistisches Recht, Leiden/Köln, E. J. Brill, 1964, pp. 49-219. Não se deve usar aqui o termo "direito» como legislação (Gesetzbücher), mas apenas como uma realidade jurídica em sentido amplo, presente em negócios, regulamentos administrativos, exortações reais à justiça, e mesmo em escritos propagandísticos de usurpadores de tronos (nesse sentido, V. KOROSEC, Keilschriftrecht cit., p. 49-50).

${ }^{18}$ A exemplo de M. A. BENEDETTO, Ricerche sugli ordinamenti dei domini del Delfinato nell'alta Valle di Susa, Torino, Giappichelli, 1953.

${ }_{19}$ Actes juridiques susiens - Mémoires de la mission archéologique de Perse: Mission em Susiene, vols. XXIII-XXIV, Paris, E. Leroux, 1932-1933, documentos de n. ${ }^{0} 166-327$ (pp. 1-217 do vol. XXIII) e 328-395 (pp. 1-129 do vol. XXIV). Sobre a situação das descobertas arqueológicas até os anos 80, v. F. VALLAT, The Most Ancient Scripts of Iran: The Current Situation, in World Archeology, $17^{3}$ (1986), pp. 335-347.

Não se pode chamar «ordenamento» a esse direito, já que ele se encontrava distribuído em uma miríade de documentos de tempos e lugares diferentes; o mesmo vale para as XII tábuas e o direito grego (V. KOROSEC, Keilschriftrecht cit., p. 50).
} 
1.500 anos depois, e que provavelmente exerceu influência, junto com o direito assírio-babilônico e o direito hitita, sobre a formação do direito privado romano. ${ }^{21}$

De acordo com o clássico estudo de J. J. RABINOWITZ, alguns contratos de compra e venda trazem a cláusula de responsabilidade por evicção na seguinte forma: pactua-se, no caso de alegação de propriedade da coisa vendida feita por terceiro, que o vendedor deverá arcar com a responsabilidade, utilizando-se o verbo izzaz. ${ }^{22} \mathrm{O}$ mais interessante é que, na opinião desse autor, a responsabilidade é efetivada com o aparecimento do vendedor em juízo, com a finalidade de tornar «limpa» a propriedade em favor do adquirente. ${ }^{23}$

Em determinada tabuleta registrou-se venda envolvendo um comprador, um vendedor e uma figura análoga a um garante, ${ }^{24}$ semelhante ao auctor secundus do direito romano, comentado neste estudo. ${ }^{25}$

Ele indica ainda como correspondente desse núcleo semântico de garantia o aramaico nazâzu, traduzido comumente por "garantido», mas cuja interpretação ainda está em aberto. ${ }^{26}$

${ }^{21}$ É a tese de R. WESTBROOK, Nature and Origins of the XII Tables, in SZ 105 (1988), p. 119: «The Twelve Tables were the product of Mesopotamian science». Os juristas romanos da República, em algum momento, teriam abandonado essa ciência jurídica em favor do método desenvolvido pelos filósofos gregos

22 The Susa tablets, the Bible and the Aramaic papyri, in Vetus Testamentum $11^{1}$ (1961), p. 59. Enquanto RABINOWITZ traduz izzaz por "will stand up (in court)», SCHEIL tradu-la por "se tiendra réponsable». Uma tradução semelhante foi feita por M. SAN-NiCOLO, Die Schlußklauseln der altbabylonischen Kauf und Tauschvertrage - ein Beitrag zur Geschichte des Barkaufes, München, Beck, 1922. Note-se que este é o mesmo significado do vocábulo grego $\beta \varepsilon \beta a i ́ \omega \sigma i \varsigma, ~ \varepsilon \omega \varsigma$, correspondente a garantia no direito romano, na teoria de E. RABEL, e que se encaixa com a noção de assistência do mancipio dans ao mancipio accipiens na reivindicação de coisa por ele vendida por parte de terceiro. Sobre isso, v. adiante nossa exposição sobre o estudo de G. PFEIFER.

${ }^{23}$ Idem, pp. 59-60.

${ }^{24}$ Não exatamente um garante, mas um proprietário de um imóvel que substituirá o perdido em razão de evicção (idem, p. 60).

${ }^{25}$ Tabuleta de n. ${ }^{\circ} 205$ (SCHEIL, Mémoires... cit., vol. XXIII, p. 14-19):

a-na ba-aq-ri-im u ru-gi-ma-an-ni

Puzur(ilu) Ma-am-mi-i u (ilu) Šušinak ilu

a-na (ilu) Sin im-gur-an-ni iz-zi-iz-zu

eqlum an-nu-um i-ba-qa-a-ar-ma

kîrum 240 (qa) zîr-šu ša šu-pa-lu-lu

ša Puzur (ilu) Ma-am-mi-i i-za-az.

A tradução francesa de V. SCHEIL é a seguinte (reproduzida em RABINOWITZ, The Susa Tablets... cit. p. 60): "Contre revendication et contestation Puzur Mammi et Susinak ilu, au lieu de Sin Imguranni, feront face. Si le champ est réclamé (par un ayant droit), un verger de 240 qa d'ensemencement, dit Supalulu, appartenant a Puzur Mamni, en répond».

${ }^{26}$ Idem, p. 61. 
O problema jurídico da garantia contra eviç̧ão ocorre ainda em outro direito antigo, o da civilização babilônica, ${ }^{27}$ que procede das civilizações mais antigas de que se tem notícia. ${ }^{28}$ Antiquíssimas tabuletas encontradas em Nippur, do período da $1 .{ }^{\circ}$ Dinastia babilônica, ${ }^{29}$ fundada por Sumu-abu em 1.830 a.C., ${ }^{30}$ e de dinastias anteriores (de Isin e Larsa), indicam a utilização de pactos semelhantes aos registrados nas inscrições cuneiformes de Susa.

Documentos de compra e venda da $1 .^{\circ}$ dinastia da Babilônia ${ }^{31}$ trazem os seguintes elementos: a própria compra (in-shi-in-sham), o pagamento do preço (in-la-an-lá) e o pacto a respeito de futuras reclamações da coisa vendida por outras pessoas, incluindo o próprio vendedor, seus parentes e herdeiros. ${ }^{32}$

Um exemplo é a inscrição ${ }^{33}$ contendo a venda de um terreno em condomínio, que transcrevemos parcialmente, na parte que contém o pacto contra alegação de propriedade pelos vendedores, seus parentes e herdeiros:

sham-til-la-bi-shù

$1 / 2$ ma-na 1 gin kú-babbar
Pela compra ${ }^{34}$ completa [da casa] meia mina lhes foi

\footnotetext{
${ }^{27}$ A civilização babilônica, de língua semítica, é considerada herdeira dos sumérios, sediada ao norte da Mesopotâmia. Ela surgiu por volta de 2.500 a.C.

${ }_{28}$ As antigas incrições babilônicas podem ser divididas em três: poéticas, históricas e legais/comerciais (S. A. B. MERCER, The Oath in Cuneiform Inscriptions - The Oath in Babylonian Inscriptions of the Time of the Hammurabi Dynasty, in The American Journal of Semitic Languages and Literatures $29^{2}$ (1913), p. 65). Entre essas últimas estão os documentos de compra e venda adiante comentados, aos quais o autor chama «contratos».

${ }^{29}$ Antes, portanto, de Hammurabi, que foi o $6 .^{\circ}$ rei da Babilônia.

${ }^{30} \mathrm{H}$. WINCKER, Geschichte Babyloniens und Assyriens, Leipzig, E. Pfeiffer, 1882, p. 46.

${ }^{31}$ Publicadas no pioneiro A. PoEBEL, Babylonian Legal and Business Documents from the Time of the First Dinasty of Babylon chiefly from Nippur, Philadelphia, University of Pennsylvania, 1909. Esse volume é resultado de uma expedição levada a cabo pela Universidade da Pensilvânia; os seus resultados foram coletados nos vários volumes editados por H. V. HILPRECHT, The Babylonian Expedition of the University of Pennsylvania - Series A: Cuneiform Texts, Philadelphia, University of Pennsylvania, 1909. Hilprecht encontrou, de 1888 a 1900, um grande número de tabuletas em Nippur, que até hoje estão sendo decifradas.

${ }^{32}$ A. POEBEL, Babylonian legal and business documents cit., pp. 6-7. As partes desses documentos são, assim, as seguintes: a compra, com uma descrição do objeto vendido, com referência ao seu gênero (jardim, casa, terreno, etc.), medidas e local; o alienante, com a fórmula ki-Y-ta |Z-ge $\mid$ inshim-in-sham; o pagamento, segundo a fórmula sham-til-lá-bi-shú |x gìn kú-babhar |in-na-an-lá(l); o pacto de não alegação de propriedade por terceiro ou pelo próprio vendedor, contendo uma promessa ou juramento em nome do Rei, embora sem qualquer menção ao seu nome. Os escribas observavam essa ordem e essas fórmulas rigidamente, sem alterá-las em nenhuma hipótese, como se se tratasse de um formulário cerimonial (idem, p. 7). Esse esquema era observado em outras regiões da Babilônia, além de Nippur.

${ }^{33} \mathrm{~N} .{ }^{\circ} 12$ (idem, pp. 3-4). A tradução para o português é pautada na tradução inglesa do próprio POEBEL.
} 
in-ne-en-lá (I)

ŭ-kúr-shú Im-gur- ${ }^{d}$ Nin-IB ${ }^{d}$ Nin-IB-a-bi

$\Upsilon^{d}$ Nin-IB-ga-mil \Ma-nu-tum ama-ne-ne

ù ibila-a-ne-ne a-na-me-a-bi

é-bi-shú gù-nu-um-mà-mà-a

mu lugal-bi in-pá(d) paga.

No futuro, Imgur-Nin/B, NinlB-abi, NinlB-gamil e Manutum, suas mães e nenhum dos seus herdeiros reclamará a casa.

Em nome do rei eles juraram.

Não há menção expressa, ao contrário do que ocorre com o direito contratual elamita, a uma sanção; mas a presença de um juramento certamente criava uma responsabilidade por parte do vendedor de «fazer valer» plenamente a venda, até pelo caráter rigorosamente formular do negócio, registrado por um oficial escriba na presença de outras testemunhas. ${ }^{35}$ Poderíamos, com toda segurança, caracterizar essa cláusula como uma espécie de pactum de praestanda evictione, embora aparentemente se restringisse a um círculo próximo de terceiros.

Contudo, analisando outros documentos de compra e venda da $1 .^{a}$ Dinastia, inclusive os editados por A. PoebeL, o jurista e historiador M. SCHORR constatou em certos negócios a previsão de uma verdadeira responsabilidade pela evicção, «Haftung des Verkäufers für Eviktion», ou seja, pela eventual venda a non domino, isto é, de coisa de terceiro com direito de reivindicação sobre ela («Schütz gegen das Vindikationsrecht Dritter»). ${ }^{36}$

A fórmula é assim concebida por ScHORR: «Für Vindikation des Hauses, resp. Feldes, Sklaven, haftet der Verkäufer». Essa cláusula está presente em documentos de Dilbat, Warka, Sippur e mesmo em um documento de Nippur, representando um tipo especial de venda, ${ }^{37}$ que reproduzimos abaixo segundo as autorizadas edições de POEBEL e SCHORR:

\footnotetext{
${ }^{34}$ Utiliza-se o verbo shâmu, "comprar», e o substantivo shimu, "preço de compra» (idem, p. 3, n. 2).

$35 \mathrm{O}$ elemento testemunhal era o que dava autenticidade ao negócio, e não propriamente o registro escrito, conforme sustenta V. KOROSEC, Keilschriftrecht cit., p. 51.

${ }^{36}$ Urkunden des altbabylonischen Zivil- und Prozessrechts, Leipzig, J. C. Hinrich, 1913, p. 111. O erudito trabalho de SCHORR utiliza amplamente os estudos de POEBEL. A interpretação dos documentos de Nippur, inclusive no que se refere à compra e venda de casa transcrita, está em consonância com a de POEBEL.

37 Idem, pp. 116-117. A tradução é pautada na tradução alemã de SCHORR, comparada com o comentário de POEBEL, Babylonian legal and business documents cit., pp. 13-14. A transcrição é praticamente igual à de POEBEL, mas preferimentos manter a de SCHORR para este caso, a fim de seguir a sua tradução.
} 


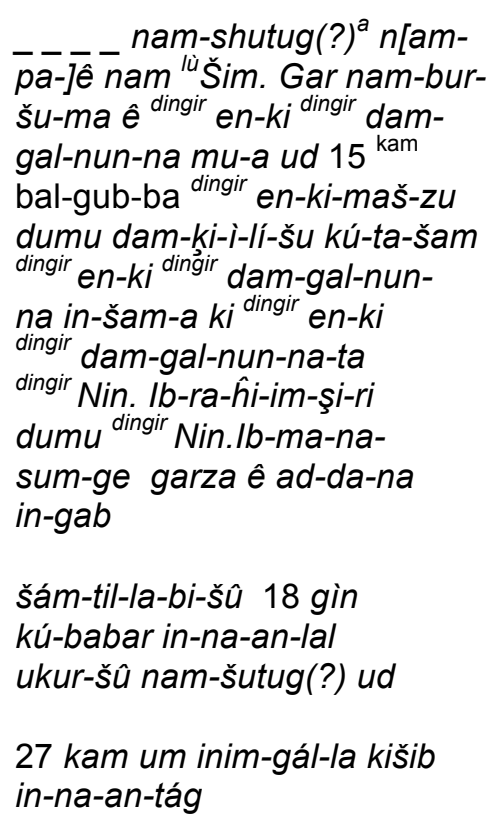

\author{
o sacerdote-ungido, o \\ secretário do Templo, o mestre- \\ cozinheiro, o porteiro, o limpador da corte, \\ e - - No \\ Templo de Enki (e) \\ Damgalnunna \\ neste ano aos \\ 15 dias, pela posse da herança (?) de \\ Enki-mašzu, filho de Damkilišu, \\ foi pago o preço por Enki (e) \\ Damgalnunna Ninib-râ'im-zêrim, \\ filho de Ninib-mansum, uma vez que [este] \\ retornou à sua casa paterna. \\ Como preço, ele pagou \\ 18 minas de prata. \\ Futuramente, pela dignidade \\ do sacerdote-ungido, dentro de 27 (?) dias, \\ ele responderá contra qualquer eventual \\ pretensão [de terceiro], \\ segundo o documento selado entregue.
}

Não há limitação de tempo para a responsabilidade, ao contrário do que ocorre com a auctoritas, de acordo com a interpretação mais corrente. ${ }^{38}$

A literatura atual tem se debruçado sobre o mesmo fenômeno. G. PFEIFER recentemente apontou o caso da evicção no mundo assírio e babilônico como exemplo da recorrência de um mesmo fenômeno em direitos diferentes, incluindo o romano e o grego. ${ }^{39}$

O seu estudo tem como base várias fontes do direito sumério, ${ }^{40}$ bem como do babilônico e do assírio em todos os seus períodos (antigo, médio e novo), baseando-se em coletâneas e estudos bastantes recentes. ${ }^{41}$

\footnotetext{
${ }^{38}$ M. SCHORR, Urkunden des altbabylonischen Zivil- und Prozessrechts cit., p. 117.

${ }^{39}$ Keilschriftrechte und historische Rechtsvergleichung - metodengeschichtliche Bemerkungen am Beispiel der Eviktionsgarantie in Bürgschaftsform, in A. SCHMIDT-RECLA, E. SCHUMANN, F. THEISEN (org.), Sachsel im Spiegel des Rechts - lus Commune Propriumque, Köln-Weimar-Wien, Bohlau, 2001, p. 19, apoiado em P. KOSCHAKER.

${ }^{40}$ Para o direito sumério, cfr. os documentos numerados deste período na edição de P. STEINKELLER, Sale Documents of the Ur-III-Period, Stuttgart, 1989, p. 197 (n. $\left.{ }^{\circ} 26\right)$, p. 209 (n. $\left.{ }^{\circ} 36 a\right)$, p. 210 (n. $\left.{ }^{\circ} 36 b\right)$, p. 326 ( $n .{ }^{\circ} 127$ ), utilizada por PFEIFER. O documento $n .^{\circ} 26$, que contém a venda de um terreno com jardim, já registra claramente a utilização de uma cláusula de proteção contra a evicção: "se alguém exercer pretensão contra o terreno vendido" (tukumbi lú inim ba-an-gar), o vendedor respondará por essa pretensão em virtude de um juramento em nome do rei.
} 
A sua conclusão, mais sutil, é que o direito cuneiforme privilegiou não a responsabilidade direta pela evicção, mas o pacto do dever de defesa que cabe ao vendedor em caso de pretensão de terceiro, presente semelhantemente no direito grego - que estudaremos adiante ao examinar trechos de Plauto - e no direito romano arcaico segundo a doutrina dominante sobre a regra do usus auctoritas das XII tábuas (sufragada por PFEIFER), ${ }^{42}$ que, a propósito, combatemos no presente estudo. $^{43}$

O Código de Hammurabi (séc. XIX a.C.), por sua vez, também faz referência à compra e venda, embora apenas a alguns casos patológicos (é dos documentos negociais que se pode inferir o seu funcionamento normal). Há, com efeito, uma passagem ${ }^{44}$ bastante pertinente tratando da venda de coisa alheia:

\begin{abstract}
§ 9. šum-ma a-wi-lum ša mi-im-mu-šu ĥalga-am i-na ga-ti a-wi-lim iş-şa-at a-wi-lum ša hu-ul-kुum i-na ga-ti-šu şa-ab-tu na-dina-nu-um-mi id-di-nam ma-har ši-bi-mi aša-am iks-ta-bi ù be-el hu-ul-kí-im ši-bi mudi hu-ul-kgi-já-mi lu-ub-lam ikg-ta-bi ja-mi ša-a-a-ma-nu-um na-di-in id-di-nu-šum ù ši-bi ša i-na maĥh-ri-šu-nu i-ša-um it-ba-lam ù be-el hu ul-kí-im ši-bi um-di ĥhu-ul-kí-šu it-ba-lam da-a-a-nu a-wa-a-ti-šu-nu i-imma-ru-ma ši-bu ša maĥ-ri-šu-nu ši-mu-um iš-ša-um ù ši-bu-mu-di hu-ul-kí-im mu-duzu-nu ma-har i-lim i-ga-ab-bu-ma na-di-nanu-um ša-a-a-ma-nu-um i-na-bi-it na-dina-nim kaspam iš-kuú-li i-li-ki.
\end{abstract}

§ 9. Si quis, cui aliquid suae (proprietatis) amissum erit, rem amissam in manu alterius invenerit, ille autem, in cuius manu res amissa inventa erit, dixerit: venditor mihi eam vendidit, coram testibus eam pependi. Et si dominus rei amissae dixerit: testes, qui meam rem amissam cognitam habent, afferam. (Si) emptor venditorem, qui eam vendiderit et testes, coram quibus eam pependerit, attulerit et dominus rei amissae testes, qui rem eius amissam cognitam habuerint, attulerit, iudices rem eorum examinabunt. Testes autem, coram quibus pretium pensum erit, et testes, qui rem amissam cognitam habuerint, testimonia sua coram deo edicent. Proinde venditor fur erit et necator. Dominus rei amissae rem suam amissam recipito. Emptor pecuniam, quam pependerit, a domo venditoris recipito.

\footnotetext{
${ }^{41}$ Cf. as fontes transcritas e analisadas por PFEIFER, Keilschriftrechte... cit., pp. 26-32, que abrangem todos esses períodos.

${ }^{42}$ Idem, p. 32-33. Segundo o autor, esse dever de defesa seria uma forma de proteção contra evicção via fiança (Eviktionsbürgschaft), diferente da responsabilidade pela evicção (Eviktionshaftung) do direito romano clássico.

${ }^{43}$ Ficará claro adiante que o presente capítulo se destina apenas a provar a possibilidade de que o problema da evicção se desse no direito romano das XII tábuas, e não que ele fosse regulado tal como descreve a doutrina dominante.

${ }^{44}$ G. PFEIFER aponta a mesma passagem (Keilschriftrechte... cit., p. 19 e n. 51).
} 
No direito grego antigo ${ }^{45}$ também há traços seguros dessa consciência jurídica natural inclinada a proteger o comprador de boa-fé na hipótese de aquisição de coisa não pertencente ao vendedor; isso prova, por um lado, a recorrência desse problema na vida corrente e, por outro, a existência de uma resposta por parte dos legisladores e negociantes.

Um dos documentos mais importantes desse direito comprova essa afirmação; trata-se de uma inscrição da primeira metade do séc. $V$ a.C. ${ }^{46}$ contendo disposições jurídicas para a pequena, mas desenvolvida, cidade de Gortyna, localizada na ilha de Creta, encontrada em 1884.

De acordo com a disposição inscrita na coluna $\mathrm{VI}, 1-56$, a pessoa,

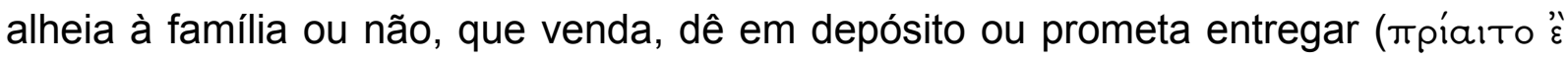

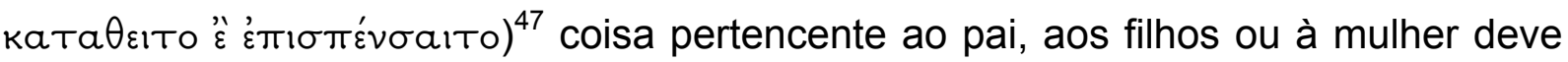
restituir in duplum ( $\delta 1 \pi \lambda \varepsilon \hat{\imath}$ кa escrito que dispuser contrariamente é nulo. ${ }^{49} \mathrm{O}$ próprio texto faz referências a leis ainda mais antigas tratando de contratos. ${ }^{50}$

Na coluna IX, 1-17, há uma disposição semelhante no que diz respeito aos bens da herdeira.

Podemos, diante de uma fragmentária mas significativa visão da proteção contra a evicção no mundo antigo - demonstrando o caráter recorrente desse problema em comunidades relativamente pouco desenvolvidas -, passar a uma descrição do desenvolvimento econômico-jurídico atingido por Roma no séc. $V$ a.C., a fim de mostrar a debilidade da tese de CASINOS-MORA.

${ }^{45}$ Cf., para uma idéia geral, M. GAGARIN, Early Greek Law, in M. GAGARIN - D. COHEN (eds.), The Cambridge Companion to Ancient Greek Law, Cambridge, Cambridge University, 2005, pp. 82-96.

${ }^{46}$ Inscriptiones creticae (IC) IV 72. O bloco inscrito faz parte de uma parede e está contida em 12 colunas num espaço de $9 \mathrm{~m}$ de largura por 1,72 metros de altura, quase inteira com exceção de partes faltantes no topo da $9 .^{a}$, da $10 .^{a}$ e da $12 .^{a}$ coluna.

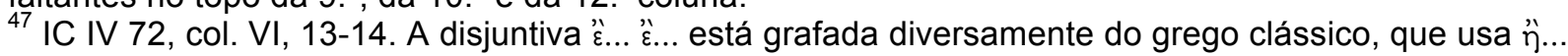
$\dddot{\eta} . .$. Os verbos estão no optativo, e exprimem a possibilidade real de que o fato se dê, baseado na experiência da vida prática.

${ }^{48}$ IC IV 72, col. VI, 20-21. Quanto aos outros danos, a indenização é pelo simples valor (Tò á $\pi \lambda$ óov).

${ }^{49} \mathrm{O}$ que se deduz claramente, mesmo com a falta de um fragmento, da sentença: "á $\lambda \lambda \hat{a}_{\imath} \delta^{\prime}$

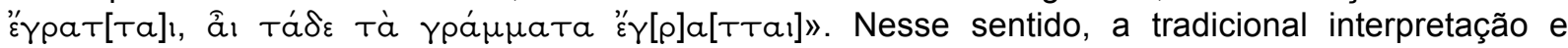
tradução de H. J. RoBY, The Twelve Tables of Gortyn, in Law Quartely Review 2 (1886), p. 147, n. 1.

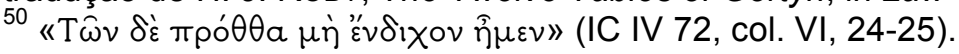


Há uma tese tradicional sobre o contexto histórico do período decenviral segundo a qual Roma, a essa época, não passava de uma aldeia rural composta de um pequeno número de cidadãos romanos, e cuja vida econômica era quase insignificante; as famílias conheciam-se entre si e os negócios que se faziam estavam dotados de extrema segurança - daí a presunção de CASINOS-MORA, fundada nessa visão, de que a venda feita por quem não fosse proprietário era uma hipótese raríssima nesse estágio de desenvolvimento, que não necessitava ser contemplada pela lei das XII tábuas.

Essa tese não tem fundamento histórico, pelos seguintes motivos: a) já no período pré-decenviral, antes da fundação da República, há notícia de disposições de direito contratual; b) os historiadores, após as descobertas arqueológicas das primeiras décadas do séc. XX, corrigiram a visão equivocada em grande parte tributária de MOMMSEN - que se tinha do desenvolvimento jurídico e econômico do período decenviral; c) os dados sobre a economia romana arcaica sobre os quais CASINOS-MORA se apóia ${ }^{51}$ são inverossíveis, de acordo com a historiografia.

Deve-se levar em conta, em primeiro lugar, a antigüidade do direito privado romano; pois há notícia da existência de normas e costumes ligados à prática negocial já nos primeiros séculos após a fundação de Roma (séc. VIII a.C.).

Com efeito, atribui-se a Sérvio Túlio (que segundo a tradição reinou de 578 a.C. a 535 a.C.), um dos reis de Roma - informação importante, de qualquer modo, mesmo se não admitimos certos dados lendários a respeito dos reis, já que o período monárquico certamente existiu ${ }^{52}$ - a edição de cerca de 50 leis sobre contratos e delitos. ${ }^{53}$

\footnotetext{
${ }^{51}$ La noción romana de 'auctoritas'... cit., p. 101, n. 209.

52 O testemunho da existência das chamadas leges regiae está em Dionísio de Halicarnasso, Tácito, Lívio, Pompônio, Plutarco, Plínio, Marcelo, Aulo Gélio, Festo, Cícero e em outros autores clássicos (cf. Bruns I, pp. 1-15; FIRA I, pp. 1-20), e foi largamente discutido pela literatura (cf. G. C. LEWIS, Untersuchungen über die Glaubwürdigkeit der altrömische Geschichte, vol. 1, 2. ed., Hannover, C. Rümpler, 1863, p. 146-149, com uma investigação dos fragmentos reunidos por H. E. DIRKSEN, Übersicht der bisherigen Versuche zur Kritik und Herstellung des Textes der Überbleibsel von den Gesetzen der römischen Könige, Leipzig, 1823, pp. 234-358; C. FERRINI, Storia delle fonti del diritto romano e della giurisprudenza romana, Milano, U. Hoepli, 1885, pp. 1-4; L. WENGER, Die Quellen des römischen Rechts, Wien, A. Holzhausen, 1953, pp. 353-357; B. BIONDI, Leges populi romani, in Scritti
} 
Não sabemos qual o seu conteúdo (e sequer se se pode admitir um número tão grande de leis), mas a fonte, cujo autor é da época de Cícero, indica já algum desenvolvimento do direito no período monárquico, pré-decenviral. ${ }^{54} \mathrm{~A}$ negação sistemática da existência de um direito positivado no período arcaico é uma presunção típica da escola histórica do séc. XIX, que ignora a continuidade, traço típico do espírito romano, fortemente ligado ao passado. ${ }^{55}$ Basta pensar, ainda, que

giuridici, v. 2, Milano, Giuffrè, 1965, pp. 189-306; A. GUARINO, L'ordinamento giuridico romano, $4 .^{\text {a }}$ ed., Napoli, Jovene, 1980, p. 82).

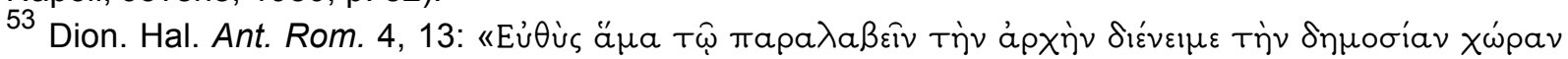

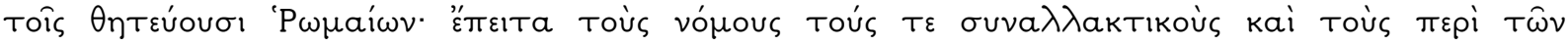

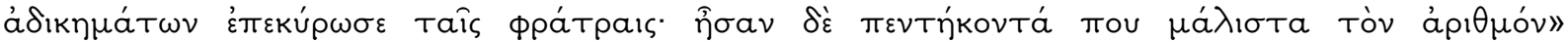
(Imediatamente após ter recebido a soberania, [Tullius] dividiu as terras públicas entre os romanos que serviam outros por um preço. Em seguida, criou leis regulando contratos privados e delitos, a serem ratificadas pelas cúrias; essas leis eram no número de 50 ). V. também Dion. Hal. Ant. Rom. 4 , 25 , sobre a divisão das causas judiciais em privadas e públicas pelo mesmo rei. Os que não aceitam, mesmo criticamente, o testemunho de Dionísio, não deveriam aceitar o de Cícero, que escreveu na mesma época.

${ }^{54}$ A tese da credibilidade, do ponto de vista substancial, das leges regiae é sustentada com fortes argumentos por A. WATSON, Roman Private Law and the 'Leges regiae', in JRSt. 62 (1972), pp. 100105. Ele afirma: «...the rules for private law recorded by the tradition actually do give us, in general, the substance of Roman law as it was in the regal period» (p. 100). Segundo o autor, há um padrão recorrente nas prescrições referidas pelos autores clássicos. No que concerne, por exemplo, às provisões sobre a relação entre patronos e clientes (patrícios e plebeus), fica clara a existência, no período monárquico, de uma relação de dependência muito forte entre essas duas classes, o que não ocorre nos períodos posteriores (na República e no Império). Tal estado de coisas não poderia ter sido inventado por Dionísio de Halicarnasso, testemunha dessas supostas leis de Rômulo. Uma comparação pode ser feita com a patria potestas: de acordo com o testemunho de Plutarco, esse poder era menor no tempo dos reis do que na República. Assim, temos duas relações jurídicas que atravessaram, segundo os autores que nos falam do período monárquico, uma evolução diversa: a relação entre patronos e clientes se tornou mais fraca e a patria potestas ganhou força. Uma invenção desse tipo seria absolutamente improvável, por implicar um conhecimento avançado de antropologia comparada por parte dos historiadores antigos. Embora não possamos saber detalhes sobre as leis reais, a sua substância, tal como a sua transmissão histórica, é digna de crédito. Deve-se lembrar, ainda, que para Cícero, as leges regiae eram um corpo vivo, assim como a lei das XII tábuas; Lívio tem a mesma certeza: «in primis foedera ac leges - erant autem eae duodecim tabulae et quaedam regiae leges» $(6,1)$, e também Tácito: «Nobis Romulus, ut libitum, imperitaverat, dein Numa religionibus et divino iure populum devinxit; repertaque quaedam a Tullo et Anco: sed praecipuus Servius Tullius sanctor legum fuit, quis etiam reges obtemperarent» (Ann. 3, 26). Para uma ampla discussão e bibliografia sobre o assunto fora do âmbito europeu-continental da romanística, cf. R. PANKIEWICZ, Tzw. 'leges regiae' a problematyka rodziny rzymskiej w epoce archaicznej, in Rodzina w społeczeństwach antycznych i wczesnym chrześcijaństwie. Literatura, prawo, epigrafika, sztuka, Bydgoszcz, Wyższa Szkoła Pedagogiczna w Bydgoszczy, 1995, pp. 59-84.

${ }^{55}$ Z. BUJUKLIĆ, Leges regiae: pro et contra, in RIDA 45 (1998), p. 93-94. A afirmação da autora é exata. As teorias "evolucionistas» do direito esquecem a história e as suas fontes - escritas ou tradicionais - e postulam, a priori, que tudo deve obedecer a uma lei de progresso: direito costumeiro, direito escrito, codificação. O mesmo acontece com as teorias hegelianas, marxistas e positivistas, que padecem de um sério problema metodológico (v., sobretudo, para uma refutação dessas teses ultrapassadas no campo do direito e da política, E. VoEgELIN, The New Science of Politics, Chicago, 
uma das mais antigas inscrições latinas já descobertas (séc. VI a.C. ${ }^{56}$ faz referência a um rei $(r e c e i=$ regi $)$, e é, provavelmente, de caráter jurídico. ${ }^{57}$

Passemos ao período decenviral. Quando veio a lume a lei das XII tábuas, Roma já era uma verdadeira cidade. Historiadores do séc. XIX, como MOMMSEN, deixaram gravada na consciência histórica européia uma imagem algo distorcida das condições econômicas dos inícios de Roma. ${ }^{58}$

Essa crítica - certamente exagerada, mas que deve ser tomada em conta - vem especialmente de T. FRANK. Já na década de 30 do séc. XX ele chamava a atenção dos juristas para o perigo, para o estudo do direito romano antigo, dos livros de história obsoletos.

Segundo ele, o jurista que segue Mommsen, supondo que Roma do séc. V a.C. era uma comunidade fazendeira primitiva, que só há pouco admitira a propriedade privada ${ }^{59}$ e pouco sabia de comércio, tenderá a excluir do seu trabalho todas as referências a contratos mais elaborados. ${ }^{60}$ Foi exatamente neste erro em que caiu CASINOS-MORA, tentando forçar uma interpretação histórica que, aliás, nem MOMMSEN apoiaria. ${ }^{61}$

De acordo com as novas descobertas arqueológicas, Roma, já antes do início da República, estava envolvida num pujante comércio marítimo e possuía uma

University of Chicago, 1952; Order and History II - The World of the Polis, Louisiana, Louisiana State University, 1957).

${ }^{56} \mathrm{CIL} \mathrm{I}^{2}$ 2, 1. Trata-se da lapis niger, uma estela do séc. VI a.C. aproximadamente, que é provavelmente o monumento referido por Fest. 177 (niger lapis in Comitio).

${ }^{57} \mathrm{~V}$. Bruns I, pp. 14-15. Alguns arqueólogos interpretaram-na como uma lei de fixação de limites territoriais (landmarks) (cf. L. A. HoLLAND, Qui Terminus Exarasset, in American Journal of Archeology $37^{4}$ (1933), pp. 549-553; A. J. AmmeRmAN, The Comitium in Rome from the Beginning, in American Journal of Archeology 1001 (1996), pp. 121-136).

${ }^{58}$ Römische Geschichte, vol. 1, 5. ${ }^{\mathrm{a}}$ ed., Berlin, Weidmann, 1868. A visão está presente em todo o primeiro volume, mas de modo bastante sutil. Não nos parece impossível conciliar, entretanto, a sua visão sobre os começos de Roma com os achados arqueológicos do séc. XX, conforme nossa exposição a seguir. MOMMSEN julgava que Roma, apesar de tudo, rapidamente se urbanizou através do comércio; o que é digno de correção, portanto, é a sua idéia do período em que isso aconteceu.

${ }^{59}$ A condenação de MOMMSEN é certamente exagerada. Estudaremos no capítulo 4 a questão do surgimento da propriedade privada em Roma nos primeiros séculos.

60 Some Economic Aspects of Rome's Early Law, in Proceedings of the American Philosophical Society $70^{2}$ (1931), pp. 193-194.

${ }^{61} \mathrm{Na}$ sua aula inaugural, que examinaremos adiante, MOMMSEN sustentou justamente que a auctoritas das XII tábuas tinha o sentido de garantia em caso de evicção. 
vigorosa indústria e um grande número de prédios decorados por artistas gregos e etruscos. $^{62}$

Não se trata de um desenvolvimento repentino; deve ter havido uma continuidade a partir dos prósperos povos que habitavam a região do Lácio antes da fundação de Roma. ${ }^{63}$

O comércio dentro da própria cidade de Roma já era muito intenso; «Rome was a large and busy commercial city», nas palavras do historiador. ${ }^{64} \mathrm{O}$

${ }^{62}$ Idem, p. 194. A importância, para o estudo da história de Roma, do cotejo das fontes literárias com as não-literárias - dados lingüísticos e arqueológicos - tem sido repisada constantemente pelos especialistas, a exemplo de A. MomIGLIANO, An Interim Report on the Origins of Rome, in JRSt. 53 (1963), p. 98 (cf. também M. PAllotino, Le origini di Roma, in Archeologia Classica 12 (1963), pp. 136, para uma vasta bibliografia sobre o estado da questão até o começo dos anos 60 , e também G. CARETTONI, Excavations and Discoveries in the Forum Romanum and on the Palatine during the Last Fifty Years, in JRSt. 50 (1960), pp. 192-203; especialmente, consultar T. RASMUSSEN, Archaeology in Etruria - 1980-1985, in Archaeological Reports 32 (1985), pp. 102-122, para uma ampla notícia das descobertas entre 1980 e 1985, que abriram um novo panorama sobre a origem da urbanização na Itália Central; as descobertas só diminuíram de 1985 a 1995, segundo o mesmo autor em Archaeology in Etruria - 1985-1995, in Archaeological Reports 42 (1995), pp. 48-58; de lá para cá, aumentou consideravelmente o material bibliográfico sobre essas descobertas, especialmente no ramo da etruscologia, segundo pormenorizada notícia de M. GLEBA, Archaeology in Etruria - 1995-2002, in Archaeological Reports 49 (2002), pp. 89-103). MomIGLIANO, com base no trabalho arqueológicohistórico de E. GJERSTAD, faz uma penetrante exposição dos achados arqueológicos mais importantes na região: a) embora não se possa provar a existência de uma continuidade entre os mais antigos habitantes e as vilas da Idade do Ferro (a partir de 1.200 a.C.), há traços evidentes de que as colinas romanas já eram habitadas no segundo milênio antes da nossa era; b) havia um grande número de tumbas no Fórum, no Esquilino, no Palatino e no Quirino, datando do séc. VIII ao séc. VI a.C.; c) entre as construções arcaicas mais importantes estão os restos de habitações encontradas no Palatino (séc. VIII a.C.?); d) um mercado (market place) - o primeiro autêntico forum romanum - teria sido construído por volta de 575 a.C.; e) encontrou-se terracotas no Fórum, no Esquilino, no Capitólio e no Palatino, do séc. VI e início do $\mathrm{V}$ que certamente eram parte de edifícios sagrados, no estilo grego e etrusco (pp. 101-102).

${ }^{63} \mathrm{O}$ povo de Terramara, por exemplo, praticou por muitos séculos uma extensa agricultura na região do Vale do Pó. A população cresceu assustadoramente, densificando-se gradualmente num território relativamente pequeno: trata-se, provavelmente, das 53 aldeias pré-romanas de que fala Plínio, Nat. Hist. 3, 68-70, afirmação apoiada por vestígios arqueológicos do séc. VI a.C., ligados às vilas de Ardea, Satricum, Lanuvium, Gabii, Praenesti, Nemi, Velitrae, Norbae e Signia; os tesouros encontrados procedem da Mesopotâmia e da região do Mar Báltico, do que se conclui que a região, no séc. VI, era cultivada com uma intensidade raramente igualada em outros locais (T. FRANK, Agriculture in early Latium, in The American Economic Review $9^{2}$ (1919), p. 267-268).

${ }^{64}$ T. FRANK, Economic aspects... cit., p. 197; cf. também R. PANKIENWICZ, Quelques remarques sur l'économie prémonetaire dans la Rome archaïque, in Acta Classica 33 (1990), p. 68, com ampla bibliografia. O estado econômico de Roma à época, devido a um intenso cultivo do solo herdado dos povos do Lácio, faz pensar na existência não só de comerciantes, mas também de grandes proprietários. Um sistema composto por pequenos fazendeiros não teria sido suficiente para sustentar os esforços e as iniciativas de longo prazo implicados na grande rede de cuniculi, extensos túneis subterrâneos, utilizados para a irrigação do solo - formando uma intrincada rede de drenagem -, descobertos há muito tempo (cf., para uma exposição técnica, F. RAVELLI - P. J. HOWARTH, Etruscan cunicoli: tunnels for the collection of pure water, in Transactions of the XII International Congress on 
antigo modo de troca e venda à vista era utilizado paralelamente aos contratos ${ }^{65}$ mais dinâmicos, empregados nos portos; a diminuição do tráfico comercial com estrangeiros só teria ocorrido depois da instituição do código decenviral, como conseqüência da expulsão dos príncipes etruscos. ${ }^{66}$

Uma das condições de possibilidade para o surgimento de relações privadas mais complexas - incluindo a garantia pela evicção - é uma população razoavelmente grande. Os historiadores clássicos estimam que a população de Roma, por volta do ano 509 a.C. - muitos anos antes das XII tábuas -, era de 130.000 habitantes. $^{67}$ A literatura especializada atual, partindo de uma visão extremamente crítica, não duvida de que se trata de uma estimativa dotada de forte credibilidade. ${ }^{68}$

Irrigation and Drainage, v. 2, Fort Collins, 1984, p. 425). Tal sistema explicaria a instituição romana da clientela como uma sobrevivência das relações entre os proprietários e os que trabalhavam nas terras, algo semelhante ao feudalismo medieval. A publicação das XII tábuas coincide, ainda, com a conquista da propriedade pelos plebeus; quanto a à propriedade comunal, é provável que não tenha sido praticada nessa época. De qualquer modo, a propriedade privada já existia há muito tempo ( $\mathrm{T}$. FRANK, An Economic History of Rome, 2. ${ }^{a}$ ed., New York, Cosimo, 2005, pp. 1-15).

${ }^{65}$ Uma cláusula do tratado entre os latinos e os romanos, datado de 493 a.C., segundo o texto conservado por Dionísio de Halicarnasso, é uma forte evidência nesse sentido. Um dos termos do tratado fala, de modo surpreendente, do julgamento de casos privados envolvendo contratos em

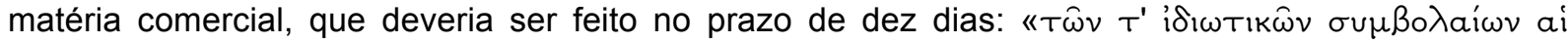

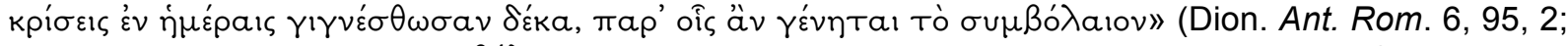

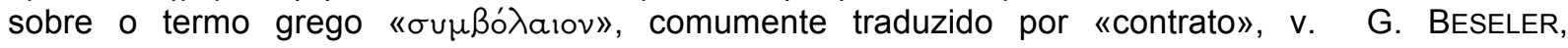
Symbolaion, in SZ 50 (1930), p. 441). Os historiadores aceitam como genuíno o texto do tratado. A presença de uma cláusula desse tipo não é usual, em se tratando de uma aliança internacional, já que, de qualquer modo, pelo instituto do commercium, já se garantia o direito de um estrangeiro realizar um contrato com um romano, submetendo-o à jurisdição romana (R. M. OLGIVIE, Early Rome and the Etruscans, Glasgow, Fontana/Collins, 1976, p. 101).

${ }^{66}$ Idem, pp. 197-198.

${ }^{67}$ Dion. Hal. 5, 20; Plut. Publ. 20.

${ }^{68}$ L. H. WARD, Roman Population, Territory, Tribe, City, and Army Size from the Republic's Founding to the Veientane War, 509 B.C.-400 B.C, in The American Journal of Philology $111^{11}$ (1990), p. 8. O censo oficial de 498 a.C., que estima a população em 150.700 habitantes, parece exagerado (idem, p. 12). Houve uma considerável queda nas décadas seguintes: 110.000 no ano de $493,106.00$ no ano de 490, o que foi confirmado pela arqueologia. Depois da grande queda até a metade do séc. $V$ a.C., a população aumentou para cerca de $120.000 \mathrm{em} 460$ (v. o gráfico de WARD na p. 36). A densidade populacional sempre foi altíssima: em 450 a.C., por exemplo, ela era de $6.390 \mathrm{hab} . / \mathrm{km}^{2}(\mathrm{v}$. gráfico na p. 34). O assunto continua sendo atualmente objeto de amplos debates, e a bibliografia é imensa; consulte-se W. SCHEIDEL, Roman Population Size - the Logic of the Debate, in L. DE LIGT - S. NORTHWOOD (eds.), Peasants, Citizens and Soldiers - the Social, Economic and Demographic Background to the Gracchan Land Reforms, Leiden, Brill, prov. 2007-2008, cuja publicação, segundo informou o autor, virá em breve (tivemos acesso ao artigo ainda não publicado). Cf. também, do mesmo autor, The Demography of Roman State Formation in Italy, in M. JEHNE - R. PFEILSCHIFTER (eds.), Herrschaft ohne Integration? Rom und Italien in republikanischer Zeit, Frankfurt, Antike, 2006, pp. 207-226, para os séculos seguintes da República. 
Todos esses fatores, se não deitam por terra os argumentos de CASINOS-MORA sobre a raridade ou ausência do fenômeno da evicção no direito decenviral, ao menos demonstram a sua debilidade como tese negativa.

Podemos afirmar, com segurança, que estavam presentes as condições históricas para que o fenômeno fosse freqüente, e que portanto é possível que as XII tábuas tivessem prescrito algo sobre ele.

Entretanto, isso não significa que a garantia pela evicção tivesse fundamento no preceito do usus auctoritas, conforme a interpretação de MOMMSEN e GIRARD. Demonstramos mais adiante, especialmente na nossa interpretação do adágio decenviral nos capítulos 3 e 4, que este não dizia respeito, ao menos diretamente, à evicção, mas à aquisição da propriedade ex iure Quiritium.

\subsection{Os vários sentidos de auctoritas}

Auctoritas é uma palavra tipicamente romana; «ein spezifisch römischer Begriff, vom römischen Wesen unzertrennlich», nas palavras de R. HEINZE. ${ }^{69}$ Não há em grego nenhum termo correspondente - informação que nos dá o próprio Cássio, historiador grego, em Hist. Rom. 55, 3, 4, ao dizer que há uma impossibilidade absoluta de verter para o grego a palavra auctoritas [aưkTúpıtac]. ${ }^{70}$ Há notícia, todavia, de uma correspondência segura de auctor, auctoritas com o umbro uhtur, uhtretie, com o significado de magistrado, magistratura, presente nas tabulae iguvinae (III, 4, 7; Va, 2, 15), ${ }^{71}$ uma questão a ser examinada adiante.

\footnotetext{
${ }^{69}$ Auctoritas in Hermes 60 (1925), p. 351.

${ }^{70} \mathrm{O}$ próprio Cássio translitera, em caracteres gregos, a palavra auctoritas. Ela não ocorre, entretanto,

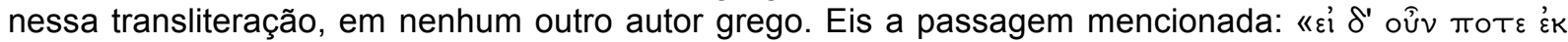

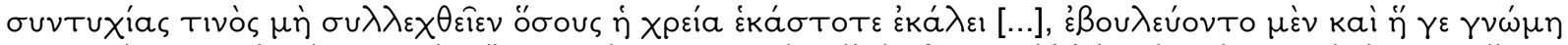

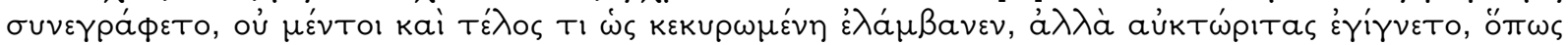

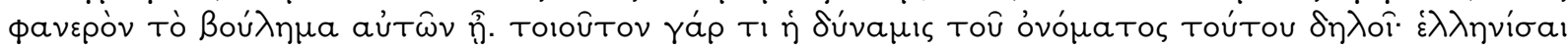

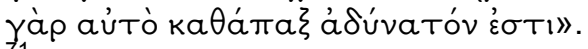

${ }^{71}$ Em III, 4:
} 
Ela foi formada tardiamente, como deitas, pueritas, e. g. O sufixo -tat(i)indica o mesmo processo: se dignitas indica a qualidade de alguém que é dignus, assim hereditas não é a herança concreta, mas uma qualidade do heres. Deste modo, auctoritas é uma propriedade de quem é auctor. ${ }^{72}$

Do ponto de vista estritamente semântico, há todo um universo contido nesse vocábulo, bem como nos seus semelhantes indo-europeus. Limitar-nos-emos ao seu significado jurídico-privado. ${ }^{73}$ Nesse sentido, podemos falar em: a) auctoritas

\author{
Esunu fuia herter sume | \\ ustite sestentasiaru | urna- \\ siaru. Huntak vuke prumu \\ pehatu. | Inuk uhturu urtes \\ puntis | frater ustentu- \\ ta, puře | fratru mersus \\ fust | kumnakle. Inuk \\ uhtur vapeře | kumnakle sistu. \\ Sakre, uvem uhtur | teitu, \\ puntes terkantur.
}

\author{
Sacrificium fiat oportet summa \\ tempestate sextantariarum *urna- \\ riarum. Puteum in aede primum \\ piato. Tum auctorem, surgenti- \\ bus quinionibus, fratres osten- \\ dunto, quomodo fratrum ex \\ moribus erit in conventu. Tum \\ auctor in sella in conventu con- \\ sidito. Hostiam, ovem auctor di- \\ cito, quiniones suffragentur.
}

Para a interpretação e tradução acima, consultar C. D. BuCK, A Grammar of Oscan and Umbrian: with a Colection of Inscriptions and a Glossary, Boston, Ginn \& Comp., 1904; e A. CATALDO JANELLI, Veterum oscurum inscriptiones, et tabullae eugubinae, latina interpretatione tentatae - tum specimina etymologica, Neapoli, ex Regia, 1841. V. adiante sobre a pesquisa etimológica. Sobre a correspondência com o úmbrico, v. U. CoLLI, I/ diritto pubblico degli umbri e le tavole eugubine, Milano, Giuffrè, 1958, comentado por J. HEURGON, JRSt. 49, 1959, p. 163-164; v. também, para a correspondência aug-/uh-tur, o antigo, mas ainda útil em parte, trabalho de W. CORSSEN, Ueber steigerungs- und vergleichungsendungen im lateinischen und in den italischen dialekten, in Zeitschrift für vergleichende Sprachforschung auf dem Gebiete des deutschen, griechischen und lateinischen, ano 3 (1854), p. 272. Voltaremos a falar da correspondência entre uhtur e auctor no item 3.3.

${ }^{72}$ R. HEINZE, Auctoritas cit., p. 349-350.

${ }^{73}$ A auctoritas de direito público, que encontramos por exemplo em Augusto, alheia à nossa esfera, foi muitas vezes erroneamente confundida com a potestas ou com dignitas. R. HEINZE, Auctoritas cit., p. 348 mostrou o equívoco dos filólogos por terem seguido Th. MOMMSEN numa tradução de uma passagem de Augusto, Res gestae 34, que até certo momento só existia numa versão grega; o erudito

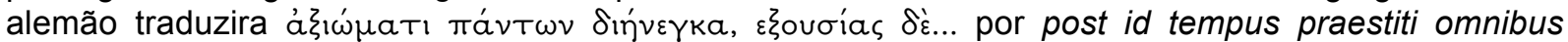
dignitate, potestate autem..., dando a entender uma oposição entre dignitas e potestas. Mais tarde, os fatos contrariaram MOMMSEN: encontrada a inscrição que faltava, podia-se ver que a palavra correta

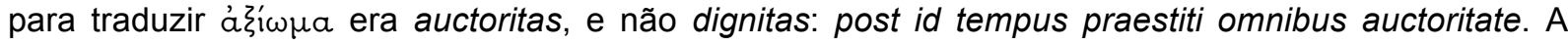
passagem completa, na edição de E. MALCOVATI, Imperatoris Augusti operum fragmenta, 1962, portanto posterior ao artigo de R. HEINZE, foi assim estabelecida: «In consulatu sexto et septimo, postquam bella [civ]ilia exstinxeram, per consensum universorum po[titus rerum omn]ium, rem publicam ex mea potestate [] in senatus populique Romani arbitrium transtuli. Quo pro merito meo senatu[s consulto Augustus appe]llatus sum et laureis postes aedium mearum v[estiti] publ[ice coro]naque civica super ianuam meam fixa est [] [et clupeus aureu]s in [c]uria lulia positus, quem mihi senatum [populumque Romanu]m dare virtutis clem[entiaequ]e iustitia[e et pietatis caussa testatum] est pe[r e]ius clupei [inscription]em. Post id tem[pus] auctoritate [omnibus praestiti, potes]tatis au[tem] nihilo amplius [habu]i quam cet[eri qui] mihi quoque in ma[gis]tra[t]u conlegae [fuerunt]». Sobre esse tema, v. E. StAEDLER, Zum Rechtsbegriff der Augustischen auctoritas Mon. Ancyr. 34, in SZ 63 (1943), p. 384; M. A. LEVY, L'auctoritas d'Augusto, in RIDA 39, 1992, p. 185-201. 
iuris peritorum; b) auctoritas iudicum et iudiciorum; c) auctoritas tutoris; d) auctoritas rerum ou auctoritas eius qui mancipio dat. ${ }^{74}$

A auctoritas dos jurisconsultos liga-se ao sentido mais original de respeitabilidade da opinião e do conselho de um homem prudente: hominum prudentium consilium et auctoritas, ${ }^{75}$ juridicamente, ao valor que se dá à doutrina dos jurisprudentes como fonte do direito civil, como está em Pap. 2 definit., D. 1, 1, 7 pr: «lus autem civile est, quod ex... auctoritate prudentium venit».

Diferente é o sentido da palavra quando utilizada no contexto das sentenças judiciais; Cícero, mais genericamente, por exemplo, empregou-a como sendo aquilo que qualifica a decisão de um juiz que procede conscienciosamente. ${ }^{76}$ Em direito processual, é aquilo de que se reveste uma sentença que fez coisa julgada $;{ }^{77}$ inclusive no que diz respeito aos juramentos (jusjurandum), a modo de analogia, que têm no direito justinianeu maior autoridade do que a coisa julgada. ${ }^{78}$

A auctoritas dos tutores ${ }^{79}$ tem um sentido bastante particular, que é o do consentimento necessário, fundamentado na experiência e na responsabilidade do encargo dado pelo tutor - interpositio tutoris auctoritate - para que o pupillus possa celebrar determinados atos jurídicos. Os impúberes que não mais estão sob a potestas, a manus ou o mancipium precisam de alguém que os proteja - esta pessoa é o tutor, e essa tutela, por essa razão, é denominada tutela impuberum.

Essa noção de proteção, segundo BONFANTE e BETTI, ligar-se-ia no direito pré-clássico aos futuros herdeiros do incapaz, diretamente interessados no patrimônio deste. ${ }^{80} \mathrm{O}$ fato é que, sendo a tutela um verdadeiro poder de acordo com

\footnotetext{
${ }^{74}$ Seguimos, apenas pela autoridade filológica e pela abundância de referências, o Thesaurus Lingua Latinae - editus auctoritate et concilio academiarum quinque germanicarum berolinensis gottingensis Lipiensis Monacensis Vindobonensis, vol. II, Lipsiae, B. G. Teubneri,1900-1906, p. 1213 e ss.

${ }^{75}$ Cic. pro Caec. 56.

${ }^{76}$ «De quo si vos [se]vere ac religiose iudicaveritis, auctoritas ea quae in vobis remanere debet haerebit; sin istius ingentes divitiae» (in Verr. 1, 1, 3). Há uma divergência nas edições: em algumas, aparece «vere», em outras «severe».

${ }_{77}$ Ulp. 14 ad. ed., D. 5, 3, 5, 2.

${ }^{78}$ Gai. 5 ad ed., D. 12, 2, 1 pr.

${ }^{79}$ V. A. J. B. SIRKS, An Aspect of Archaic Roman Law: Auctoritas Tutoris, in F. J. M. Feldbrugge, The Law's Begginings, Leiden-Boston, Martinus Nijhoff, 2003, p. 45 e ss.

${ }^{80}$ P. Bonfante, Corso di diritto romano - vol. I, Roma, Attilio Sampaolesi, 1928, p. 554; E. BeTtI, Istituzioni di diritto romano I, § 39, p. 65 e ss.
} 
a clássica definição, ${ }^{81}$ o consentimento que, na linguagem moderna, «integra a vontade do incapaz», é chamado auctoritatis interpositio.

Quanto à auctoritas rerum - a que nos interessa neste trabalho -, se vamos às suas fontes, a única informação que podemos ter, a princípio, é a de que ela está ligada aos fundi e a ceterarum res; é a mesma auctoritas que alguns romanistas ligam de forma indissolúvel à mancipatio. ${ }^{82}$

No direito decenviral, só se mencionam três institutos relacionados: a auctoritas patrum, a auctoritas tutoris e a auctoritas rerum. Não saberíamos dizer à primeira vista se esta última tem ou não alguma conexão com a auctoritas tutoris, ou mesmo com a auctoritas patrum de direito público, e se essas formas se ligariam a uma idéia geral, por exemplo de prestígio moral ou social.

\subsection{A denominação auctoritas rerum ou simplesmente}

\section{auctoritas}

A expressão auctoritas rerum nada mais é do que uma contração de uma disposição ${ }^{83}$ das XII tábuas (VI, 3) que nos foi transmitida por Cic. top. 4, 3: USUS AUCTORITAS FUNDI BIENNIUM EST[O], - CETERARUM RERUM OMNIUM - ANUUS EST USUS. $^{84}$

Outro uso do termo foi feito pela lex Atinia, transmitida por Gell. 17, 7: QUOD SUBRUPTUM ERIT, EIUS REI AETERNA AUCTORITAS ESTO. Se reconstituimos o termo com base nesse preceito, teremos auctoritas rei, no singular. Teremos de pressupor que a outra disposição das XII tábuas a respeito da auctoritas se referia também às coisas (III, 7): ADVERSUS HOSTEM AETERNA AUCTORITAS [RERUM] ESTO.

\footnotetext{
${ }^{81}$ Paul. 38 ad ed., D. 26, 1, 1 pr: «Tutela est, ut Servius definit, vis ac potestas in capite libero ad tuendum eum, qui propter aetatem su[a] sponte se defendere nequit, iure ciuili data ac permissa».

${ }^{82} \mathrm{~V}$. item 2.4 , adiante.

${ }^{83}$ Ou paráfrase de uma disposição, como veremos.

${ }^{84}$ Bruns I, p. 25. Poderia surgir a suspeita de que o melhor termo seria auctoritas fundi, já que a lei decenviral diz que no que se refere às demais coisas o seu usus é de um ano (annus est usus), sem mencionar auctoritas. De qualquer modo, auctoritas rerum é também mencionada por Cícero, pro Caec. 26, 74.
} 
A expressão auctoritas eius qui mancipio dat já foi utilizada na literatura, mas pressupõe uma posição acadêmica específica, que liga a auctoritas estreitamente à mancipatio. O mesmo quanto à chamada auctoritas mancipationis. Como veremos, o estudo de certas fontes literárias pode levar a essa conclusão. De qualquer modo, todos os romanistas que cuidaram do tema fizeram amplo uso da disposição das XII tábuas ao falar do papel da auctoritas rerum.

A expressão mais neutra é auctoritas, sem restrição por meio de adjunto adnominal; mas ela, isoladamente, não permite dizer se se está referindo à auctoritas de direito privado ou à de direito público. Se o contexto está bem delimitado, contudo, parece-nos conveniente empregá-la assim.

\subsection{Teorias sobre a extensão e a compreensão do} conceito de auctoritas

A doutrina se divide quanto à unicidade ou pluralidade do termo auctoritas, quando trata da auctoritas rerum. Uns julgam que esta é uma manifestação específica de um mesmo conceito genérico; outros que a auctoritas rerum possui um significado técnico sem relação com as demais formas. ${ }^{85}$

R. HeINZE, que citávamos, entende que a existência de um elemento comum às várias realidades a que se dá o nome de auctoritas é evidente. $\mathrm{Na}$ auctoritas rerum, o auctor é supostamente o vendedor de uma res mancipi, e a auctoritas constitui o auctorem esse: o estado ou posição que permite ao auctor continuar, em virtude da venda, obrigado a garantir o comprador nos casos de contestação da regularidade da sua aquisição por terceiros — ou seja, alegando que o vendedor não é proprietário. ${ }^{86}$

\footnotetext{
${ }^{85}$ A distinção entre essas posições, como veremos, é sutil, mas ao mesmo tempo radical. Para compreendê-la, é necessário ter-se em mente que o direito romano, mesmo o do período antigo, é bastante rigoroso e utiliza, nos escritos que chegaram até nós, vocábulos com um sentido técnico preciso. A questão a ser discutida é se a auctoritas rerum possui um sentido técnico radicalmente distinto, a ponto de não se poder falar em uma auctoritas genérica; ou se há um forte traço comum que permita dizer que a auctoritas rerum é uma espécie do gênero auctoritas. Como essas posições são extremas, a resposta mais razoável estará provavelmente entre uma e outra.

${ }^{86}$ Idem, ibid.
} 
Mas auctor é também o tutor que intervém com a sua auctoritas nos negócios do seu pupilo (auctoritatem interponere); e auctores são os que intervinham com a sua auctoritas nas resoluções legislativas e votavam nos comícios.

No caso da mancipatio, segundo certa teoria, o comprador, na presença do vendedor e de outra testemunha, declara que a coisa é de sua propriedade, pelo pagamento do preço. O auctor aqui colabora como alguém que dá a conhecer a sua aprovação a essa declaração; só ele está na posição de dizê-lo, por ter sido o proprietário da coisa até aquele momento; e por isso daí em diante ela pertence efetivamente ao comprador. É deste modo que o auctor adota a posição de garante.$^{87}$ Algo semelhante ocorreria com o tutor e os patres.

O filólogo então se permite formular um traço comum para esses três fenômenos: auctor é aquele que aprova [gutheißt], de modo efetivo, um ato praticado por outrem. O fato da aprovação ser «abalizada» (maßgeblich) implica responsabilidade. ${ }^{88}$

Para prová-lo, HeINZE analisa ainda algumas passagens de Plauto e nelas encontra três sentidos para auctor/auctoritas: a) o de conselho, na construção quid mihi auctor es?, que significa algo como «que conselho me dás?»; b) o de autorização, como em suspende, vinci, verbera: auctor sum, sino (Poen. 196); c) o de autoria de uma idéia, como em si experiatur usque ab stirpe auctoritas unde quidquid auditum dicant (Trin. 217). ${ }^{89}$

Esses três sentidos são harmônicos entre si e estariam de acordo com o conceito geral de «aprovação que torna abalizado o ato de outrem»; ${ }^{90}$ em favor

\footnotetext{
${ }^{87}$ Idem, ibid.

${ }^{88}$ Idem, p. 351.

${ }^{89}$ HEINZE emprega uma edição diversa da de F. LEO, Plauti comoediae, vol. II, 1896, que utilizamos; nesta, ao invés de experiatur, está exquiratur.

${ }^{90}$ Auctoritas cit., p. 352.
} 
dessa posição está a analogia que E. RABEL faz com a $\beta \varepsilon \beta a i \omega \sigma l \varsigma^{91}$ do direito grego, que significa confirmação (lat. firmare), usada na redação de vários negócios. ${ }^{92}$

No mesmo sentido, F. DE VISSCHER parte da crítica à tese - que aparece, entre outros, em P. F. GIRARD - que considera a auctoritas apenas em função da garantia por evicção contida na mancipatio, excluindo da pesquisa os textos onde as palavras auctor e auctoritas são empregados em um sentido que vai além da garantia. ${ }^{93}$

Ele recorre a uma suposta auctoritas original, existente antes da sua diferenciação nos direitos público e privado. A auctoritas dos patres teria o sentido de ratificação ou aprovação de uma resolução popular proposta pelo magistrado, de acordo com a doutrina dos haruspices (distinção entre o fulgur consiliarium e o fulgur auctoritatis, o primeiro ocorrendo antes e o segundo após o ato), o mesmo ocorrendo com a aprovação dada aos antigos testamentos públicos e com a dada pelo tutor (auctoritas tutoris). ${ }^{94}$

Na mancipatio, ficaria claro o mesmo sentido técnico de ratificação ou confirmação do vendedor à declaração unilateral de aquisição: HUNC EGO HOMINEM EX IURE QUIRITIUM MEUM ESSE AIO, etc. ${ }^{95}$

Forte prova dessa concepção analógica, segundo DE VISSCHER, seria a definição de Festus do termo fundus. De acordo com ela, vulgarmente falando, quando alguém dá o seu assentimento a uma aquisição de terreno, torna-se auctor. ${ }^{96}$

\footnotetext{
${ }^{91}$ H. G. LIDDELL - R. SCOTT, A Greek-English Lexicon, 9. ${ }^{\text {a }}$ ed., Oxford, Oxford University, 1983, p.:

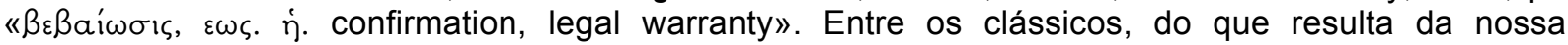

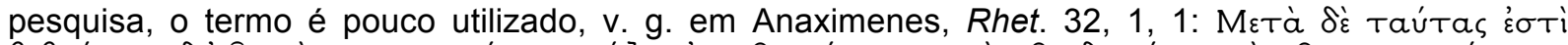

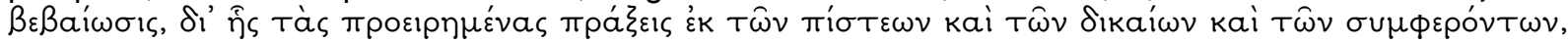

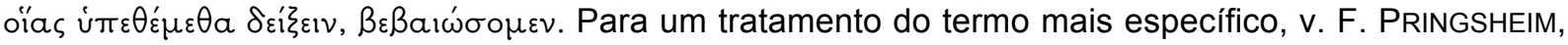
The greek law of sale, cit., p. 310 e ss.

${ }_{92}$ Para as fontes gregas, v. E. RABEL, Die Haftung des Verkäufers wegen Mangels im Rechte, Leipzig, Veit \& Comp., 1902, p. 6, n. 2; p. 7, n. 2-5.

93 Le rôle de l'auctoritas dans la mancipatio, RH 12, 1933, p. 607.

${ }^{94}$ Idem, p. 608-609.

${ }^{95}$ Idem, p. 609-610.

${ }^{96}$ «Fundus... dicitur populus esse rei, [quam] alienat, hoc est auctor» (Fest. 89). Esse fragmento não consta da editio princeps de 1500, o codex festi farnesianus, que não trazia nada antes da letra "M": trata-se de uma reconstituição de acordo com a Epitome de Paulus Diaconus, que aparece nas duas melhores edições, na de C. O. MüLLER, mais antiga, e na de W. M. LINDSAY (v. Sexti Pompei Festi De verborum significatu quae supersunt cum Pauli epitome, Hildesheim, G. Olms, 1965). F. DE VISSCHER claramente recorre a Bruns II, p. 10, que por motivos óbvios não conhecia esta última edição. Só ouso levantar uma questão. Quando diz: «Fundum fieri se dit d'un people qui donne son assentiment,
} 


\section{P. NOAILLES segue a mesma linha de crítica a GIRARD. ${ }^{97}$ É verdade que GIRARD defende a existência de uma auctoritas}

genérica; mas o sentido de auctor como aquele que intervém numa situação com a finalidade de confirmar (algo) ${ }^{98}$ - tendo como paradigma o caso da mancipatio, em que o vendedor assiste o adquirente - é para ele nuclear, e mais antigo. ${ }^{99}$

etc», parece entender que populus, no texto de Fest. 89, se refere ao populus romanus; mas parece que populus aí pode indicar uma conotação popular: "o vulgo diz» que fundus é a coisa cujo alienante torna-se auctor. A tradução da expressão fundus fieri, invocada por DE VISSCHER, de qualquer forma, é muito difícil. Depois da descoberta de uma tábua de bronze em Heracléia (dita VII tabulae Heraclensis, v. Bruns I, n. ${ }^{0} 18$ ) com a chamada lex lulia municipalis, alguns estudiosos procuraram dar uma nova interpretação à expressão. Na linha 160, vemos: "Quei lege pl(ebeive) sc(ito) permissus est fuit, utei leges in municipio fundano, etc.». Mas ao contrário do que acreditaram alguns, a expressão municipio fundano não é - pela communis opinio atual, a partir de GRADENWITZ - uma lei geral concernente ao fundus, mas sim uma referência aos munícipes de Fundi. Outra tentativa semelhante foi rejeitada por M. CARY, JRSt. 27, 1937, p. 51-2. Isso nos deixa apenas com a discussão de Cic. pro Balb.; nela, Cícero parece reviver essa antiga expressão fundus fieri, de acordo com a qual "uma comunidade deve aceitar voluntariamente uma parte da lei romana»; uma vez que a cidade de Balbo, Gades, não o fez, ele não teria direito à cidadania romana, etc. O outro sentido da palavra é dado pelo Thesaurus Linguae Latinae, e esse é o sentido mais próximo a Festus, derivando de "fundação» mas significando, para pessoas, a sua qualidade de auctor, talvez «garante». Para uma notícia dessa discussão, v. M. HAMmOND, Germana patria, in Harvard Studies in Classical Philology 60 (1951), pp. 147-174, especialmente a passagem final: «lt appears, therefore, that the only 'classical' discussion of fundus fieri is that by Cicero in the pro Balbo. Aulus Gellius may make more sense than modern critics have thought and may have sought information outside of Cicero, but he does not add anything significant to Cicero's discussion. Paulus/Festus, even if the text is sound, are confused between the meaning of fundus as auctor, attested in Plautus, and the meaning of 'acceptor'...» (p. 163). Como veremos no capítulo 4, a expressão fundus fieri faz referência a uma antiga noção de fundus como modo de participação numa comunidade.

${ }^{97}$ L'auctoritas dans la loi des douze tables, in Fas et Jus - études de droit romain, Paris, Belles Lettres, 1948, p. 223-276.

${ }_{98} \mathrm{O}$ verbo confirmar é transitivo; mas a definição genérica não traz consigo o objeto da confirmação: pode ser um ato, uma situação, ou até um processo.

${ }_{99}$ L'action auctoritatis, in NRH 6 (1882), p. 183. Para GIRARD, auctor e auctoritas possuem várias acepções: a) auctor seria aquele de quem recebemos a propriedade; b) auctoritas designa a obrigação de garantia da evicção que o vendedor assume (auctoritatem promittere), ou mesmo o direito a essa garantia (auctoritatem stipulari); c) auctoritatem defugere designa o ato do vendedor que frustra a confiança do adquirente (p. 182-183). Os critérios utilizados por ele para aferir qual a noção mais antiga são o da menor abstração e o da maior aproximação com o significado etimológico do termo (augere); este segundo critério é julgado arbitrário por NOAILLES (L'auctoritas cit., p. 247). O resultado da aplicação desses critérios é o seguinte: o mancipio dans é auctor porque aumenta, melhora a situação do réu na reivindicação da coisa vendida por terceiro; é nesse sentido etimológico que se poderia encontrar um traço comum - numa posição próxima, mas não idêntica, à de HEINZE, Auctoritas cit., p. 352 - às noções de auctoritas tutoris, auctoritas patrum e auctoritas rerum. NOAILLES objeta que na regra do usus-auctoritas das XII tábuas o sentido de auctoritas é já desviante do sentido primitivo aqui indicado: pois não é a assistência que dura um ou dois anos, mas o dever de assistência (L'auctoritas cit., p. 247). A crítica geral de NOAILLES procede, mas talvez seja o caso de nos perguntarmos se o objetivo de GIRARD era justamente o de falar da auctoritas do ponto de vista da mancipatio - assumindo ainda como certa a vinculação essencial entre ambas as realidades jurídicas. Cremos, todavia, que mesmo assim não se pode salvar a doutrina de GIRARD; a sua opção 
Para NOAILLES, o seu erro está no atribuir à etimologia um poder de distinção que ela não pode ter, e também no escolher arbitrariamente qual seria a noção original de auctoritas e quais as derivadas. ${ }^{100}$ Entretanto, observa que o sentido genérico de aumento (augeo) atribuído à auctoritas não se aplica da mesma forma ao tutor e ao mancipio dans: o tutor confere força ao ato realizado pelo pupilo, e o mancipio dans confirma o próprio adquirente. ${ }^{101}$

Esse autor ainda censura a GIRARD o não perceber que nem a auctoritas tutoris nem a auctoritas patrum possuem qualquer parentesco com a idéia de garantia; ${ }^{102}$ e também F. LEIFER, que propõe uma distinção radical entre os três tipos de auctoritas mencionados, dizendo que há entre elas apenas uma analogia superficial. ${ }^{103}$

A proposta de NOAILLES é ver nessas três espécies de auctoritas a aprovação de um ato realizado por outros, alinhando-se a HEINZE e em parte a DE VISSCHER. A distinção está em que a natureza dessa aprovação é muito diferente em cada caso. ${ }^{104}$

Procurando afastar-se da etimologia, LÉVY-BRUHL sustenta que auctoritas tem um sentido geral de autoridade, prestígio, influência, e, em um significado mais técnico, de poder, aproximando-se de potestas. ${ }^{105}$

Esse sentido seria mais original quando aplicado à auctoritas do povo, do imperador, dos juízes, da coisa julgada, da lei, do direito, dos jurisconsultos, etc. $^{106}$

metodológica acaba mesmo por tomar a auctoritas eius qui mancipio dat como uma noção mais original de auctoritas.

${ }_{100}$ L'auctoritas cit., p. 248.

101 Idem, ibidem. A crítica de NoAILLES é sutil, mas não logra, neste ponto, desbancar a posição de GIRARD.

102 Idem, p. 249.

${ }^{103}$ Mancipium und auctoritas, in SZ 66 (1936), p. 164.

104 L'auctoritas cit., p. 257. A distinção não nos interessa no momento; quanto ao sentido de auctoritas como aprovação, NOAILLES vai mais longe, chegando a afirmar que a se trata de um privilégio, de um elemento integrante da personalidade jurídica dos romanos, como a potestas. Estudaremos essa noção no item seguinte.

${ }_{105}$ "Auctoritas» et usucapion, in Nouvelles recherches sur le très ancien droit romain, Paris, Recueil Sirey, 1947, p. 19-20.

106 Por exemplo, em Res gestae 6, 21; Cic., in Pis. 8. Para as fontes jurídicas, cf. Auctoritas et usucapion cit., p. 20, n. 16-20; p. 21, n. 21-24. Sobre a auctoritas na jurisprudentia, v. F. DE VISSCHER, 
Nos domínios do direito público e privado, a auctoritas teria assumido um sentido especial, técnico, para cada hipótese.

No direito público, teríamos a auctoritas patrum e a auctoritas populi relativa à adrogatio. A primeira, como vimos, consistia na auctoritatis interpositio, no consentimento dado pelo senado com a finalidade de legitimar uma decisão do povo, tornando-a efetiva. Ela seria semelhante à potestas. Já na auctoritas populi de que nos fala Gaio ${ }^{107}$ haveria um caráter marcante de decisão, mais do que de simples ratificação. ${ }^{108}$

Em matéria de direito privado, teríamos a auctoritas do pai no casamento, a do tutor, aquela relativa às provas judiciárias e aquela relativa à mancipatio. A do tutor seria uma espécie de potestas; ${ }^{109}$ já a auctoritas das provas judiciárias significaria o próprio título de propriedade ${ }^{110}$ e a credibilidade das testemunhas. ${ }^{111}$

É nesse âmbito das provas que se inseriria a auctoritas ligada à mancipatio, segundo LÉVY-BRUHL. O seu papel nesse modo de transferir a propriedade seria o de uma declaração particularmente eficaz a conduzir o juiz a julgar contra o adversário. ${ }^{112}$

De acordo com LÉVY-BRUHL, o liame entre essas várias acepções técnicas de auctoritas é fraco, mas existe. Auctoritas tem um sentido geral de autoridade legítima, de poder moral ou jurídico a produzir certos efeitos. Esse poder se exerce sobre coisas, e não sobre pessoas, como ficaria claro na auctoritas fundi. ${ }^{113}$

La jurisprudence romaine et la notion de l'«auctoritas», in Recueil d'études sur les sources du droit en honneur de F. Geny, t. 1, Liechtenstein, Topos, 1977, pp. 32-41.

107 Gai. 1, 98: «Adoptio... duobus modis fit, aut populi auctoritate aut imperio magistratus, veluti praetoris»; Gai. 1, 99: «Populi auctoritate adoptamus eos qui sui juris sunt».

${ }_{108}$ Auctoritas et usucapion cit., p. 22.

109 Paul. 38 ad ed., D. 26, 1, 1 pr: «Tutela est, ut Servius definit, vis ac potestas in capite libero ad tuendum eum, qui propter aetatem su<a> sponte se defendere nequit, iure civili data ac permissa. Tutores autem sunt qui eam vim ac potestatem habent». Confirma-o Gell. 19, 10.

${ }_{111}^{110}$ CIL III 1898; VI 8439.

${ }_{111}^{11}$ Por exemplo, em Calistr. 4 de cogn., D. 22, 5, 3, 4.

${ }_{112}^{112}$ Auctoritas et usucapion cit., p. 23-24.

${ }^{113}$ Idem, p. 24. A afirmação é ousada; mas este não é o lugar para discutir essa questão. 
M. KASER, filiando-se a HEINZE, toma o significado de auctor, auctoritas como «Vermehren» dado por WALDE-HOFMANN, ${ }^{114}$ e aplica-o ao ato da mancipatio e à vindicatio; em ambos os casos, haveria um acréscimo no sentido de complemento. Algo semelhante ocorreria na esfera da auctoritas tutoris e da auctoritas patrum e senatus. ${ }^{115}$

V. ARANGIO-RUIZ sustenta uma tese semelhante, ao dizer que auctoritas teria mesmo, a partir da etimologia, o sentido de garantia, assistência, como supostamente nos outros casos (tutoris, patrum, etc.). ${ }^{116}$

Mas é de se levar em conta a crítica de T. MAYER-MALY à pesquisa etimológica de uma raiz comum para o termo. ${ }^{117}$ Mesmo com resultados interessantes até agora - a associação do grupo auctor, augere, augurium, augurare, augustus com o sânscrito मान māna, ${ }^{118}$ e a aproximação da raiz latina aug-, presente no indo-europeu, com o védico ओजस् ójas ${ }^{119}$ - ainda não há, segundo ele,

\footnotetext{
${ }^{114} \mathrm{~V}$. nota adiante.

${ }^{115}$ Altrömisches Eigentum und usucapio, in SZ 105, 1988, p. 133.

${ }_{117}^{116}$ La compravendita in diritto romano, vol. II, Napoli, Jovene, 1954, p. 313.

117 Studien zur Frühgeschichte der usucapio II, in SZ 78, 1961, p. 236 e ss. Até o momento, já se escreveu alguma coisa sobre essa raiz etimológica: R. HEINZE, Auctoritas cit., p. 348 e ss.; LEUMANN, in Gnomon 13, 1937, p. 32 e ss.; H. WAGENVOORT, Roman dynamism, Westport, Greenwood, 1976, p. 12; G. DumÉZIL, Augur, in Revue des Études Latines 35 (1957), p. 142; J. GondA, Ancient-indian ojas, Latin augos and the Indo-European nouns in -es-/-os, Utrecht, A. Oosthoek, 1952, p. 76.

118 "Honra», do verbo mān, que também significa "aprovar» (Cf. M. MoNIER-WILLIAMS, A Sanskrit-
} English dictionary, etymologically and philologically arranged, $2 .^{a}$ ed., Oxford, Clarendon, 1960, p. 809; A. A. McdonelL, A practical Sanskrit dictionary, Oxford, 1924, p. 59). De fato, o substantivo māna tem também o significado de prestígio social («consideration, regard, respect, honour») entre os hindus, num sentido próximo ao de auctoritas. Fornecemos um exemplo do Bhagavad-gītā 6, 7: जितात्मनः प्रशान्तस्य परमात्मा समाहितः शितोष्णसुख्दुःखेषु तथा मानापमानयोः jitātmanah praśāntasya / paramātmā samāhitah / śítoşna-sukha-duhkheşu / tathā mānāpamānayoh (Trad. baseada na de L. SCHRÖDER, Bhagavadgita - Des Erhabenen Sang, Düsseldorf-Köln, Diederichs, 1952: «Para a pessoa que dominou a sua própria alma, o Paratma já foi atingido, pois ela alcançou a tranqüilidade. Para ele, felicidade e contrariedade, calor e frio, honra e desonra são a mesma coisa»).

${ }^{119}$ A nova edição de M. Monier-WILLIAMS, A Sanskrit-English cit., p. 235, dá como certo o parentesco entre o védico ओजस् ójas, as - que também tem o sentido de «suporte» - e a raiz latina aug-, com augere, augur, Augustus, auxilium, e com o grego aü $\xi \omega$. Da nossa parte, pensamos também em

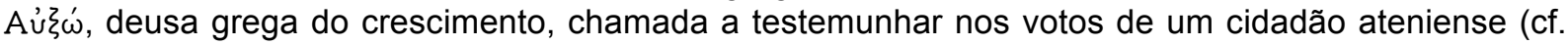
Pausan. Graec. descript. 9, 35, 2, 3). Os estudos sobre essas relações, até o momento, mal começaram. 
elementos suficientes para que se possa afirmar algo novo sobre a natureza da auctoritas. $^{120}$

Os resultados das pesquisas de J. GondA e G. DumÉZIL, conforme nosso estudo, nos levam à mesma conclusão. ${ }^{121}$

MAYER-MALY, por sua vez, tem a auctoritas rerum como sendo um conceito isolado (garantia), sem parentesco próximo com as outras formas de auctoritas. ${ }^{122}$

\subsection{Posicionamento}

Há uma unanimidade no que diz respeito à existência de uma certa analogia entre os termos auctoritas (rerum), auctoritas patrum, auctoritas tutoris, etc. Pretendeu-se atribuir à auctoritas três sentidos gerais: o de poder ${ }^{123}$ ou prestígio social; o de garantia; e o de augere, aumento. A antiga teoria de A.

\footnotetext{
${ }^{120}$ Studien zur Frühgeschichte der usucapio cit., p. 237-238.

121 Os estudos de J. GoNDA e G. DUMÉZIL partem de bases totalmente diferentes; é preciso portanto escolher uma linha de raciocínio. A do segundo nos parece mais adequada, além de ser mais recente (o autor republicou com algumas alterações o artigo anteriormente escrito para a Revue des Études Latines na coletânea Idées romaines, $2 .^{\text {a }}$ ed., Paris, Gallimard, 1982, p. 79 e ss.; o estudo de J. GoNDA fora apreciado por A. MINARD, Bulletin de la Société Linguistique 51, 1955, p. 31-32). Os estudos de DUMÉZIL podem ser sintetizados assim: a) a raiz indo-européia aug- perdeu-se no indo-iraniano ( ${ }^{*} a u \hat{j}-$ as não tem apoio em uma raiz viva), tendo sido substituído por vrdh-, «aumentar, acrescer»; b) o védico ójas assumiu estritamente a "segunda função», de força física, principalmente no contexto guerreiro, e aplicado aos deuses, especialmente a Indra. Ójas é mais uma causa da honra, námas, do que a própria honra (por exemplo, Rgg Veda 8, 75, 10); é como um estoque de força: balahetu hrdayagatam dhairyam, "a firmeza, alojada no coração, que causa a força exterior», segundo o comentador Sāyaņa. Com esse sentido J. GondA está de acordo (Ancient-indian ójas cit., p. 44-46). A raiz latina *augus, de uso talvez ainda mais arcaico, se afasta do ójas védico no seguinte sentido: enquanto os augura são sinais de força em sua plenitude, ójas indica essa própria plenitude. Quanto aos vocábulos auctor, auctoritas, ele os associa positivamente à raiz aug-, dizendo ainda que essa conexão é direta e auto-evidente; todavia, não julga conveniente a comparação entre augustus e auctor feita por Cic., de harusp. 18: «rerum bene gerendarum auctoritates augurio... contineri» (Augur cit., p. 82-101).

${ }^{122}$ Idem, p. 255, alinhando-se a GIRARD, KASER e ARANGIO-RUIZ. O autor ainda nos faz notar que, dependendo da posição que se toma sobre a natureza jurídica da auctoritas rerum - se é uma forma de garantia ou uma forma de «autoridade», uma posição de poder -, há uma tendência a considerá-la um conceito isolado ou analógico (idem, p. 235). A visão da auctoritas como posição de poder costuma vir acompanhada da noção de uma auctoritas genérica, analógica. Estudaremos a natureza da auctoritas no item seguinte.

${ }^{123}$ Nesse sentido também GIFFARD, Le sens du môt «auctoritas», in RH 17, 1938, p. 362; RoussiER, Ius auctoritatis, in RH 29, 1951, p. 233; e W. KUNKEL/T. MAYER-MALY. HONSELL, Römisches Privatrecht cit., p. 173.
} 
MAGDELAIN, que considerava a auctoritas um «título de transferência», ${ }^{124}$ não tem abrangência suficiente sequer para uma tentativa de aproximação.

Os estudos sobre a etimologia do termo, ${ }^{125}$ como vimos, são ainda insuficientes. A proximidade entre o sentido da raiz -aug e o sânscrito māna e a possível correspondência da auctoritas com o védico ójas favorece especialmente a posição de LEVY-BRUHL; entretanto, seria difícil conciliar esse significado comum indo-europeu com a auctoritas rerum - mesmo partindo das conclusões de NOAILLES, que sustenta que a auctoritas é um elemento que integra a personalidade jurídica. ${ }^{126}$

Todavia, todas essas noções têm um certo parentesco.

Quanto à etimologia latina - auctor, auctoritas com origem em augeo, «Vermehren» -, a especulação não nos parece muito fértil, embora possa ter apoio real na formação do vocábulo. Qualquer posição jurídica implica um acréscimo, desde que venha em favor daquele que a detém. Os exemplos são incontáveis. Podemos provar essa impropriedade empregando uma reductio ad absurdum: até a manumissão de um escravo constituiria um augere, pelo acréscimo havido no status libertatis.

O verbo augeo, assim como o seu antônimo minuo, pode ser aplicado à própria auctoritas. Isso fica claro numa passagem de Cesar, gall. 7, 30: «Itaque ut reliquorum imperatorum res adversae auctoritatem minuunt, sic huius ex contrario dignitas incommodo accepto in dies augebatur». ${ }^{127}$ Embora a redundância semântica

\footnotetext{
${ }^{124}$ RIDA 5, 1950, p. 136. Em De l'auctoritas patrum à l'auctoritas senatus, in lura 33, 1982, pp. 25-26, todavia, este autor defende que esses tipos de auctoritas remontam ao direito arcaico, possuindo um ponto de partida comum: o conferir o auctor um valor jurídico a um ato que não é auto-suficiente. Assim, dever-se-ia falar num conceito unitário, apesar da diversidade das aplicações.

${ }^{125}$ V. também A. WALDE, J. B. HofMANN, Lateinisches etymologisches Wörterbuch, $5^{\mathrm{a}}$. ed., Heidelberg, C. Winter, 1982, p. 80: «[Auctor]: Forderer, Veranlasser, Urheber, Gewährsmann».

${ }^{126}$ Seria impossível conciliar a realidade da auctorias rerum na mancipatio com a idéia geral de poder ou prestígio. Na prática, o prestígio pessoal mancipio dans em nada auxiliava o mancipio accipiens: eram os elementos formais da mancipatio, a presença de testemunhas, etc., que davam força à prova da realização do negócio. O próprio LEVY-BRUHL o reconhece (Auctoritas et usucapion cit., p. 24).

127 Sobre a ligação entre dignitas e auctoritas, R. HEINZE, Auctoritas cit., p. 349, n. 1; Callistr. 4 de cogn., D. 22, 5, 3, 2, relativo às testemunhas; Cic. de inv. 2, 166, tratando-as como sinônimos; «auctoritas minuere» ocorre em Cic., de rep. 2, 59. V. também Sen., epist. 101, 2: «Facilius enim crescit dignitas quam incipit», com um sinônimo. Há usos de auctoritas que sequer implicam um acréscimo propriamente dito, e cujo sujeito é uma coisa, e não uma pessoa (Ces., gall. 3, 8, 1, com auctoritas civitatis; Gell. 20, 6, 12: «nisi auctoritas quaedam vetustatis»; Pap. 2 resp., D. 10, 1, 11 pr.: «vetera monumenta census auctoritas»).
} 
seja comum, ${ }^{128}$ ocorrências desse tipo provam que o conceito de auctoritas, seja qual for a sua especificidade, possui uma forte independência.

Em razão disso, não causa espanto o fato de que seja perfeitamente aplicável à condição do mancipio accipiens, ou à própria mancipatio - e isso não significa que subscrevamos, aqui, a teoria da auctoritas como garantia ligada à mancipatio. Pois que relação haveria entre a auctoritas de um imperador e a auctoritas de uma pessoa que vendeu uma coisa? ${ }^{129}$ Em ambos os casos há um «aumento»; mas dizê-lo nada acrescenta.

O sentido geral de ato que aprova o ato praticado por outrem nos parece, apenas à primeira vista, mais acertado. Mas augere ou «Vermehren», e auctor como is qui auget pura e simplesmente - como aliás já notou HEINZE - ${ }^{130}$ não dão conta da especificidade dessa definição.

Contudo, é difícil demonstrar que a auctoritas ligada à mancipatio - de modo necessário ou não -, mesmo supondo que a teoria que a sustenta seja verdadeira, tenha relação com esse sentido de aprovação. No ato do mancipio dans ou auctor que confere maior peso ao ato do mancipio accipiens no momento da sua defesa contra reivindicação de terceiro, não é fácil enxergar propriamente um mero «aprovar» (gutheißen, aú$\theta \varepsilon \nu T \varepsilon i v)$ ). Isso só ocorre com a auctoritas do tutor, cujo

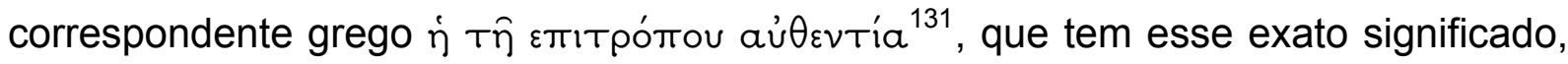
confirma-o.

O sentido de auctoritas como poder causa dificuldades ainda maiores. Não é o prestígio pessoal do auctor que lhe confere essa autoridade. Muitas vezes, a auctoritas em sentido geral têm-na coisas concretas e até abstratas: auctoritas

\footnotetext{
${ }^{128}$ Semelhante é o exemplo de DUMÉZIL com base nos estudos de A. BERGAIGNE: as conexões entre a raiz indo-iraniana vrdh-, "aumentar, acrescer» com o substantivo avesta aojah (védico ójas, ligado ao indo-europeu *aug-), embora não freqüentes, são instrumentais; quando ligadas, significam «crescer por meio da ójas» (Augur cit., p. 89).

${ }^{129}$ Ainda não enfrentamos a questão do sujeito da auctoritas na XII tábuas: se é o alienante ou o adquirente quem exerce a auctoritas. Sobre isso, mais adiante.

${ }_{130}^{130}$ Auctoritas cit., p. 349 e ss.

131 Theoph. 2, 21 (C. A. FABROTus ed., Corpus juris civilis, Theophili antecessoris intituitionum libri IV,

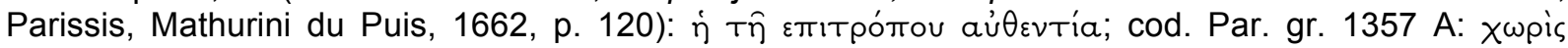

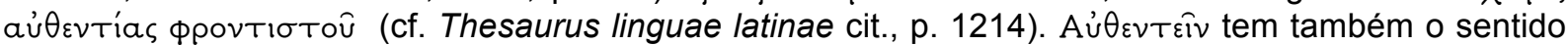

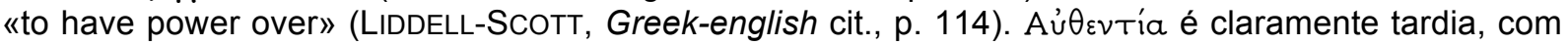
mais força no período bizantino.
} 
vetustatis, ${ }^{132}$ auctoritas civitatis, ${ }^{133}$ auctoritas aequitatis, ${ }^{134}$ para citar alguns exemplos, incluindo um da literatura jurídica. ${ }^{135}$

Ainda mais absurdo é aplicar a noções tão díspares de auctoritas, como a auctoritas senatus e a auctoritas rei judicatae, à idéia de garantia, por evidente. Ninguém o pretendeu de modo claro e absoluto. A noção de garantia é extremamente restrita, e nem à auctoritas rerum se tem atribuído apenas esse sentido; o que se extrairá da nossa exposição posterior. ${ }^{136}$

Podemos concluir que as várias "espécies» de auctoritas têm uma fraca analogia entre si; se há um conceito geral de auctoritas, ${ }^{137}$ não nos parece possível apreendê-lo. Talvez seja mais correto dizer que cada grupo de ocorrências do termo no corpus textual latino, acompanhado ou não de um genitivo ou palavra com função sintática análoga, possui uma significação distinta. No âmbito jurídico, essa diferenciação aumenta ainda mais, em se tratando de sentidos técnicos.

Para sabermos, assim, o que é a auctoritas rerum, teremos de investigar a sua natureza.

\footnotetext{
${ }^{132}$ Gell. 20, 6, 12; Quint., orat. 3, 7, 26.

${ }^{133}$ Ces., gall. 3, 8, 1.

${ }^{134}$ Apul. Mad., Metam. 9, 27.

135 Poder-se-ia objetar que se trata de um poder jurídico; o problema é que, mesmo assim, só se poderia incluir nessa noção alguns usos da auctoritas. De modo algum se poderia aplicá-la a todos os casos, como ficou patente.

${ }^{136} \mathrm{~V}$. itens seguintes.

137 Poderíamos arriscar atribuir ao termo geral auctoritas o sentido de força ou peso conferido à pessoa ou à coisa que a detém; ao menos, esse é invariavelmente o seu efeito. Essa força pode ser a credibilidade (Cic., epist. Att. 9, 10, 10), o prestígio social ou moral, a legitimidade, a capacidade de convencer, opinar, julgar ou influenciar (Cic., pro Cluentio 139), a respeitabilidade - no que diz respeito às coisas antigas, por exemplo, auctoritas census ou vetustatis -, o poder (Cic., Phill. 3, 5), a capacidade de fundar ou originar, e até a responsabilidade: Liv. 2, 48, 8: «auctores sumus», respondemos pelo fato.
} 


\section{Teorias sobre a natureza da auctoritas}

\subsection{A visão tradicional, dos humanistas ao séc. $X X$}

O significado da auctoritas das XII tábuas que nos foi transmitido pelos humanistas não é o de garantia ou de posição jurídica - que são as duas teorias hoje defendidas pelos romanistas, que serão estudadas adiante -, mas o de direito de propriedade, posse ou o de usucapião. Isso foi inicialmente pouco notado pela doutrina. ${ }^{138}$

Mas já na paráfrase grega de Teófilo encontramos essa interpretação, que seria desconhecida até há pouco tempo caso só conhecêssemos as Institutas de Justiniano e não se tivesse descoberto o texto das Institutas de Gaio.

Gaio, com efeito, diz textualmente: «usucapio autem mobilium quidem rerum anno completur, fundi vero et aedium biennio; et ita lege XII tabularum cautum est» (Gai. 2, 42); e «lex enim XII tabularum soli quidem res biennio usucapi iussit, ceteras vero anno» (Gai. 2, 54).

Justiniano só se refere à proibição de usucapir coisas furtadas, prevista na lei das XII tábuas e na lex Atinia. Nada menciona quanto ao preceito do usus auctoritas. ${ }^{139}$

O que fica claro no texto de Gaio é que a regra do usus auctoritas... já era interpretada como uma disposição sobre a aquisição da propriedade - ou melhor, da própria coisa - pela posse ou usus durante um certo prazo; versando, portanto, sobre usucapião (conforme o nome dado posteriormente, sob um regime diferente, a esse modo de aquisição).

Os humanistas que desconheciam o texto de Gaio podiam reportar-se

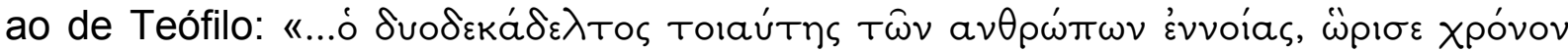

\footnotetext{
${ }^{138}$ Seguimos em parte P. NoAILlES, L'auctoritas dans la loi des douze tables cit., p. 227 e ss., mas preferimos nos apoiar na nossa própria pesquisa sobre a noção tradicional de auctoritas; convém anotar que C. GIRAUD, em obra que citamos adiante, já havia mencionado os mesmos autores antigos muito antes de NOAILLES.

${ }^{139}$ Inst. 2, 6, 2: «Furtivae quoque res et quae vi possessae sunt, nec si praedicto longo tempore bona fide possessae fuerint, usucapi possunt: nam furtivarum rerum lex duodecim tabularum et lex Atinia inhibet usucapionem».
} 


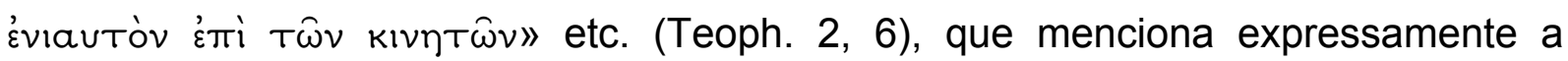
disposição decenviral.

A tendência, de qualquer modo, era ver na regra decenviral dois elementos distintos: o usus, a posse como apreensão fática, e a auctoritas, a propriedade ou o reconhecimento jurídico da posse. ${ }^{140}$

Ainda no séc. XVI, Alciat interpretava assim a passagem em que Cícero se refere à referida disposição: "Tullius usucapionem autoritatem appellat». ${ }^{141}$ Mesmo apoiando-se no texto de Venul. 17 stipul., D. 21, 2, 76 - que será muito importante para os autores que, mais tarde, afirmarão ter a auctoritas a natureza de garantia -, Alciat afirmava que a auctoritas é o direito que tem o auctor de reivindicar a sua coisa. ${ }^{142}$

Semelhantemente escrevia Budé: «Auctoritas etiam nomen est unum ex iis quae dominium rerum perficiuntur». ${ }^{143}$ Cícero, segundo ele, dava por sinônimos iure auctoritatis e iure usucapionis. ${ }^{144}$ Diversamente de Alciat, entretanto, Budé entendia que usus et auctoritas eram requisitos do usucapião, ao transpor essas antigas noções para o direito justinianeu; ${ }^{145}$ mas Cujácio, muito antes dos autores modernos, concebia a auctoritas, embora sem referência à lei das XII tábuas, como obrigação de garantia. ${ }^{146}$

A maior autoridade filológica daquele século, por sua vez, dava à auctoritas o significado de posse (jouissance) que se exerce sobre alguma coisa. ${ }^{147}$ Esse sentido mais amplo permite, ao menos, afastar uma enorme contradição: se

${ }^{140}$ Como na tradicional interpretação ainda vigente no séc. XIX: «Zwei Jahre (ein Jahr) soll gewährt haben der Usus und seine Rechtsbegründete Kraft» (L. Lange, Römische Alterthümer, vol. 1, Berlin, Weidmann, 1856, p. 124).

${ }^{141}$ De verborum significatione libri quatuor, Lugduni, S. Gryphius, 1530, p. 171. Cf. também G. SeEbode, C. JAHN, R. KLOTZ, Neue Jahrbücher für Philologie und Paedagogik, vol. 32, parte 1, Leipzig, Teubner, 1841, p. 272: «wofür man später usucapio sagte», referindo-se à passagem das XII tábuas mencionada por Cícero.

${ }^{142}$ Idem, p. 171-172.

143 Annotationes in quatuor \& vinginti Pandectarum libros, ad loannem Deganaium Cancellarium Franciae, Parissis, R. Stephani, 1535, p. 357.

144 Idem, ibidem.

145 «Usum et auctoritatem vocavit usucapiendi conditionem, quae olim erat biennii in rebus soli: ut auctor est lustinianus in secundo Institut» (idem, ibidem).

${ }^{146}$ Paratitla in libris VIII Codicis Justiniani, lib. VIII, tit. XLIV, que citamos de Jacobi Cujacii Opera, ad parisiensem fabrotianam editionem, t. 8, Prati, Fratr. Giachetti, 1839, p. (col.) 1276: «auctoritatem sive evictionem praestat».

${ }^{147}$ R. EstienNE, Dictionarium, seu latinae linguae thesaurus v. 1, Lutetiae, R. Stephani, 1531. 
auctoritas é o mesmo que usucapião, como conceber que, contra o hostis, o prazo previsto seria infinito ${ }^{148}$

No séc. XVII, R. J. POTHIER, ao comentar sobre os efeitos da compra e venda segundo o sistema francês, interpretava usus-auctoritas como usucapio: «hoc enim decemviri constituerunt, ut fundus quidem biennio, ceterae res anno usucaperentur»; e a regra da aeterna auctoritas como proibição dirigida aos peregrinos de adquirir a propriedade quiritária - presumindo assim que auctoritas significava propriedade. ${ }^{149}$

O humanista G. VICO, no séc. XVIII, em um contexto diferente, mas se referindo diretamente às XII tábuas e ao usucapião, afirmava que a auctoritas é simplesmente o nome antigo do direito de propriedade, dominium, proprietas. ${ }^{150}$

Já no séc. XIX, G. HeInECCIUS seguiu a idéia mais antiga, que a identificava com o usucapião. ${ }^{151}$

Os pandectistas, por exemplo W. REIN ${ }^{152}$ e G. F. PUCHTA, ${ }^{153}$ mesmo concebendo-a como direito de propriedade, perceberam a suposta contradição em que haviam caído Budé e Alciat e começaram a esboçar uma teoria da auctoritas como garantia legal. O mesmo sustentavam os autores ingleses, romanistas ou não, da metade para o final do séc. XIX, ${ }^{154}$ e também um antigo autor francês. ${ }^{155}$

\footnotetext{
${ }^{148}$ Notou-o NOAILLES, L'auctoritas dans la loi des douze tables cit., p. 233.

149 Pandectes de Justinian, mises dans um nouvel ordre, t. 1, Paris, Donney-Duppré, 1808, p. 448. Para ele, usus-auctoritas significa a aquisição do legítimo domínio pelo usus ou pela posse (idem, $p$. 450).

${ }^{150}$ Della costanza del giurisprudente, Napoli, Morano, 1861, p. 286: «proprietas sive auctoritas».

151 Antiquitatum romanorum jurisprudentiam illustrantium syntagma, Francofurti ad Moenum, H. L. Broenneri, 1841, p. 380. No mesmo sentido, L. A. WARNKÖNIG, Institutiones iuris Romani privati, in usum praelectionum academicarum vulgatae cum introd. in universam iurisprudentiam et in studium iuris romani, $4^{\text {a }}$. ed., Bonnae, A. Marci, 1860, p. 86.

152 Das Privatrecht und der Civilprocess der Römer, Leipzig, F. Fleischer, 1858, p. 247: «das Eigentumrecht dauert eine Zeit von 2 Jahren».

${ }^{153}$ Cursus der Institutionen, v. 1, Leipzig, Breitkopf-Härtel, 1881, p. 203.

${ }^{154}$ A exemplo de G. LONG, no artigo sobre a auctoritas em W. SMITH, A Dictionary of Greek and Roman Antiquities, London, J. Murray, 1875, p.173: «auctoritas, as applied to property, is equivalent to legal ownership... [and] sometimes signifies a warranty or collateral security». V. também J. G. PHILLIMORE, Private Law among the Romans, from the Pandects, London-Cambridge, Macmillan and Co., 1863, p. 319; E. C. CLARK, Early Roman Law: the Regal Period, London-Cambridge, Macmillan and Co., 1872, p. 114; W. H. BUCKLER, The Origin and History of Contract in Roman Law down to the End of the Republican Period, London, C. J. Clay \& Sons, 1895, p. 72.

${ }^{155}$ C. GIRAUD, Recherches sur le droit de propriété chez le romains - sous la République et sous l'Impire, t. 1, Aix, Aubin, 1838, p. 210.
} 
Mesmo assim, já no início séc. XX, o Thesaurus Linguae Latinae, da maior autoridade filológica, ainda definia a auctoritas como «ius possesionis vel dominii, quod usu paratur vel per emptionem aliquis accipit». ${ }^{156}$ Recentemente, outro filólogo definiu a auctoritas como «droit de revendication». ${ }^{157}$

NOAILLES, apesar de ser o primeiro romanista a chamar a atenção de modo fundamentado para essa antiga concepção, erra - ou ao menos permite que Ihe censuremos o raciocínio pouco claro - ao atribuir a originalidade dessa sinonímia entre auctoritas e usucapio a Budé e a Alciat. Na verdade, como vimos, essa identificação da disposição das XII tábuas como sendo uma regra de usucapião, e mesmo a identificação de auctoritas com usucapio, já existia pelo menos confusamente em Gaio e Teófilo, e até em Cícero. Os juristas franceses estavam apenas seguindo a tradição.

\subsection{A auctoritas como garantia}

A seguir, faremos uma brevíssima exposição das posições dos autores que se inserem na linha "garantista» de análise da auctoritas decenviral, sem no entanto descer a detalhes - isto será feito quando examinarmos as bases dessas teorias e as colocarmos à prova, no item seguinte.

T. Mommsen talvez tenha sido o primeiro a dar o passo definitivo, rompendo com a interpretação usual do fenômeno da auctoritas. Ele não é

\footnotetext{
${ }^{156}$ Cit., p. 1213. Esse seria o significado do vocábulo auctoritas na lei das XII tábuas e na lex Atinia de usucapione. Os autores do thesaurus, bem ou mal, não parecem ter consultado os estudos jurídicos sobre o tema; a única obra citada (a referência é nossa) é a de G. F. ScHOEMANN, De voce auctor, in Opuscula academica, t. III, Berolini, Weidmanniana, 1858, p. 402 e ss., de cunho filológico. Sequer se referem a R. HEINZE. A esse tempo, já haviam criticado de modo fundamentado essa noção MOMMSEN e GIRARD, e mesmo os pandectistas já haviam percebido essa dificuldade. As citações de Venul. 17 stipul., D. 21, 2, 76, Scaevol. 5 dig., D. 13, 7, 43 pr., Pap. Vat. 10, PS. 2, 17, 1 e 3, que são feitas apropriadamente, não se compaginam, todavia, com a definição dada pelo verbete: pois como conciliar o significado de ius possessionis vel dominii com Pap. Vat. 10? Não se pode realizar uma stipulatio convencionando o ius possessionis vel dominii. Poder-se-ia salvar essa interpretação alegando que se trata de um aspecto do direito de propriedade; mas essa distinção teria de ser feita expressamente. Só com um estudo sobre o desenvolvimento posterior da evicção se pôde mostrar esse erro com clareza (v. P. F. GIRARD, Les stipulations de garantie, in NRH 7 (1883), pp. 537-602).

$157 \mathrm{~J}$. CollaRT, A propos du mot auctoritas, in Helikon 1 (1961), p. 212. V. também, do mesmo autor, Varron: grammariere latin, Paris, Belles-Lettres, 1954, pp. 203-204, em que ele interpreta uma passagem em que Varrão inclui a auctoritas entre os quatro elementos da latinitas. Sobre esse assunto, G. BARBINO, L'auctoritas di Plauto in Nonio Marcello, in I. TAIFAcos (ed.), The Origins of European Scholarship, Stuttgart, Franz Steiner, 2005, p. 91 e ss.
} 
certamente o primeiro a fazê-lo; mas foi ele quem introduziu o debate no campo científico, ainda em $1843 .{ }^{158}$

Enquanto os humanistas e os que the seguiram entenderam a disposição decenviral com ênfase na noção de aquisição da propriedade (título, usucapião), como vimos, MoMmSEN deu ênfase à garantia que o mancipio dans presta ao mancipio accipiens por ocasião da mancipatio; ${ }^{159}$ a auctoritas, para ele, é a própria obrigação de defesa, como notou à mesma época A. J. RIETSTAP. ${ }^{160}$

$\mathrm{Na}$ história do estudo da auctoritas, entretanto, a dissertação de MOMMSEN tem pouca importância, já que ela só veio a ser publicada após os estudos de GIRARD, em 1909, com o lançamento das suas obras completas.

De qualquer modo, essa interpretação de MOMMSEN e de juristas anteriores supõe um estreitamento da noção de auctoritas, de um sentido amplo para um sentido mais técnico; e será essa concepção a dominar em todo o século XX.

O mérito cabe, com efeito, a P. F. GIRARD, por ter criado uma nova teoria da auctoritas com base nessa ligação com a idéia de garantia - mais especificamente com a assistência processual do mancipio dans -, ainda em 1882. ${ }^{161}$

É de se notar, entretanto, que G. HUSCHKE já havia tratado com algum detalhe da auctoritas como garantia muito antes de GIRARD. ${ }^{162}$

${ }^{158}$ De auctoritate commentatio, in Gesammelte Schriften III, Weidmann, 1907, p. 458 e ss. Essa sua dissertação inaugural não parece ter sido publicada à época, como nos informa MAYER-MALY, Studien zur Frühgeschichte der usucapio I/ cit., p. 235, n. 65. A tese, encomendada pelos seus professores de Kiel, era sobre a lex de scribis et viatoribus animadversiones; MOMMSEN descobriu que se tratava de um fragmento do documento legislativo em que o ditador Sila eleva a vinte o número de questores. A essa dissertação segue-se a De auctoritate commentatio, um estudo sobre o termo auctoritas.

159 «Auctoritas igitur est conditio eius, qui quia mancipavit vendiditve ad evictionem vitiaque praestanda obligatus est» (De auctoritate commentatio cit., p. 459).

${ }^{160}$ De venditore, an evictionis nomine cogatur emtorem defendere, ex jure romano, Hagae, H. P. de Swart \& Fil., 1854, p. 8: «Mommsen... docet auctoritatem iudicare ipsam defensionis obligationem».

${ }^{161}$ L'action auctoritatis cit., p. 180 e ss.

162 Über das Recht des nexum und das alte römische Schuldrecht - eine rechtshistorische Untersuchung, Leipzig, Gebauer, 1846, p. 180 e ss. Para ele, um dos efeitos do mancipium é a garantia por eviç̧ão. Ele afirma que ao mancipio dans que transferia a propriedade sobre a coisa, ou que tinha de socorrer o mancipio accipiens caso essa transferência fosse questionada, se lhe chamava auctor, a auctoritas seria assim a própria transferência da propriedade e também a sua responsabilidade ou obrigação, "Verpflichtung», diante da não transferência. A actio auctoritatis seria 
Sem qualquer menção à interpretação tradicional, GIRARD começa por sustentar, como fizera HUSCHKE, ${ }^{163}$ que a noção mais arcaica de auctor não é a de alguém que transfere a propriedade, e nem a de quem atua como garante, mas a daquele que assiste o adquirente numa eventual reivindicação de terceiro intentada contra ele. Assim a auctoritas, conseqüentemente, não é a obrigação de garantia, nem o modo de adquirir, mas essa mesma assistência concreta. Essa concepção é a que estaria mais de acordo com a etimologia do termo, ${ }^{164}$ embora seja ainda mais estreita que a de MOMMSEN.

É verdade que, mais tarde, auctoritas teria passado a significar a obrigação de fornecer essa assistência, e depois toda aquisição do direito de propriedade, e mesmo esse próprio direito de propriedade. A existência de uma tal noção tardia é, portanto, para GIRARD, indubitável. ${ }^{165}$

Ao realizar o seu trabalho de reconstrução de um dos títulos do edictum perpetuum, com a rubrica «De auctoritate», O. LENEL adotou essa teoria. ${ }^{166}$ Voltaremos a ele adiante.

A. Pernice sustentou, no mesmo sentido, que a auctoritas é a própria garantia que o alienante presta ao adquirente por ocasião da celebração da mancipatio. $^{167}$

a ação que assegura o cumprimento dessa obrigação (p. 180). A mais antiga fonte dessa doutrina - e o mais antigo uso da palavra - seria Plaut. Curc. 498; mas o conteúdo dessa instituição pode ser retirado dos seus desenvolvimentos posteriores através da stipulatio duplae e habere licere e da actio empti. A auctoritas seria a relação de garantia, "das Verhältnis der $\beta_{\varepsilon} \beta a i ́ \omega \sigma ı$ », usando o vocábulo grego empregado pelos glosadores. Na disposição decenviral, auctoritas seria a garantia plena que viria após dois anos de usus: "die vollkommene Sicherstellung» (pp. 181-182, nt. 268-269). Essa afirmação é polêmica: quase todos os romanistas do século XX defenderam que a auctoritas permanece somente durante esse tempo, e que depois se torna desnecessária, em virtude da aquisição da coisa por usucapião. Isso teremos de discutir adiante.

${ }^{163} \mathrm{~V}$. nota anterior.

${ }^{164}$ L'action auctoritatis cit., p. 183. Perceba-se que, mesmo assim, a sua idéia da auctoritas arcaica, mesmo pré-decenviral, esta diretamente relacionada com a de garantia. Auctoritas não é, para ele, a obrigação de garantia, mas um efeito dessa suposta obrigação. Essa afirmação será objeto de forte crítica, como veremos. Quanto à etimologia, GIRARD se questiona se esse «aumento» se referiria ao mancipio accipiens ou à própria mancipatio. Já demonstramos que essa inquirição etimológica pouco elucida.

${ }^{165}$ Idem, p. 185. Essa constatação seria uma chave para a compreensão do tratamento dado ao termo pelos humanistas e pelos que Ihes sucederam, assim como a própria idéia que dele tinham Gaio e Teófilo. V. também a crítica de F. BuONAMICl, Actio auctoritatis dell'antico diritto romano, in Archivio Giuridico Filippo Serafini 29 (1882), p. 73 e ss.

${ }^{166}$ Das Edictum Perpetuum - ein Versuch zu seiner Widerherstellung, 2. ${ }^{a}$ reimpr. da $3 .^{\circ}$ ed., Aalen, Scientia Verlag, 1974. 
O. KARLOWA por sua vez afirma que o mancipio dans assume através da mancipatio a auctoritas pela aquisição do mancipio accipens. Destarte, o significado de auctoritas seria que o mancipio dans faz-se - num possível processo de restituição da coisa vendida movido contra o mancipio accipiens por um terceiro - «autor», «originador» (Urheber) da aquisição pela mancipatio, a atuar como colaborador do adquirente e a suportar o periculum iudicii.

A diferença com relação à teoria de GIRARD é que, para ele, ao invés de decorrer da mancipatio pura e simplesmente, a auctoritas teria de ser "convencionada» através de uma nuncupatio. Pois aquilo que foi dito através de uma nuncupatio, afirmou KARLOWA, foi dito in mancipio, ou seja, in mancipii lege. Se a mancipatio é um ato pelo qual se obtêm efeitos jurídicos importantes, não se poderia admitir o surgimento de uma responsabilidade pela aquisição sem que ela tivesse sido expressamente criada pela lingua, de acordo com as XII tábuas (uti lingua nuncupassit, ita ius esto). ${ }^{168}$

Ele crê ter encontrado uma prova disso no já citado Plauto, Curc. 494 e ss., ${ }^{169}$ supondo ser a menção de lingua uma alusão à nuncupatio, pela qual se convenciona a responsabilidade pela evicção; e em Cícero, pro Mur. 2, também citado, que se refere a um declarare - no contexto da mancipatio e do periculum iudicii -, verbo que seria por sua vez uma alusão à nuncupatio. Por fim, cita Varro, de ling. lat. $6,74,{ }^{170}$ que menciona a lex mancipiorum, adicionada à nuncupatio que devia ser usada pelos negociantes para garantia contra evicção.

\footnotetext{
167 A idéia pode ser inferida da sua exposição sobre a actio auctoritatis em Labeo - römisches Privatrecht im ersten Jahrhundert der Kaiserzeit, v. 3, Allen, Scientia, 1963, p. 115 e ss. No mesmo sentido, G. SCHARFF, Die Lehre vom Gewährerlass (pactum de non praestanda evictione) nach römischen Recht, Greifswald, F. W. Kunike, 1888, p. 12.

168 Römische Rechtsgeschichte - vol. II, Leipzig, Veit \& Comp., 1901, p. 373. Uma posição semelhante, concebendo a auctoritas como «Rechtsurheberschaft» e o usus-auctoritas como ««Rechtsurheberschaft der längeren Benutzen», embora sem mencionar a necessidade de nuncupatio, é R. LEONHARD, Institutionen des römischen Rechts - ein Lehrbuch, Leipzig, 1894, p. 304.

169 «Egon ab lenone quicquam

mancupio accipiam, quibus sui nihil est nisi una lingua, qui abiurant si quid creditum est? alienos mancupatis,

alienos manu emittitis alienisque imperatis, nec vobis auctor ullus est nec vosmet estis ulli».

170 «A quo caveri postea lege coeptum est ab his, qui praedia vem derent, vadem ne darent; ab eo ascribi coeptum in lege mancipiorum 'vadem ne poscerent nec dabitur'».
} 
Julgando superada, por absurda, a tese da necessidade da nuncupatio, E. RABEL concebe a auctoritas como o dever (Verpflichtung) de garantia do mancipio dans, ou seja, de defender o comprador ativa e passivamente diante de uma pretensão de terceiro à coisa, por meio de reforço da prova. Tal dever se assenta, por sua vez, «an dem Mangel des Rechtes des Verkäufers» - afirmação que se relaciona com a tese central do seu livro. ${ }^{171}$

P. BONFANTE, no tratamente definitivo que deu à matéria, crê que a mancipatio transferia a propriedade independentemente do pagamento do preço; e que seu efeito particular necessário e exclusivo era «la garanzia che il mancipante doveva prestare all'acquirente», ${ }^{172}$ dotada da actio auctoritatis, no que segue GIRARD e a reconstrução de LENEL.

Essa auctoritas implicaria a obrigação de assistência judiciária, periculum iudicii praestare, quando houvesse contestação da propriedade transmitida; referir-se-ia ao seu inadimplemento com a expressão auctoritatem defugere. Para que esse efeito surja, não é necessário fazer-se uma nuncupatio, já que se trata de uma conseqüência «diretta e inevitable».

Já DE VISSCHER aceita a "demonstração decisiva» de GIRARD no tocante à auctoritas como elemento necessário e inerente a qualquer mancipatio, mas discorda deste quanto à natureza do instituto. ${ }^{173}$

Há que partir, segundo ele, do estudo da mancipatio. Há um ponto central desse negócio solene, que é o ato que dá o fundamento a toda a operação: a declaração, feita pelo comprador, de que a coisa é sua pelo direito quiritário e de que

\footnotetext{
${ }^{171}$ Die Haftung des Verkäufers wegen Mangels im Rechte, Leipzig, Veit \& Comp., 1902, p. 5 e ss., especialmente p. 18-19. Uma conjectura de RABEL é que, para ajudar na prova do direito do comprador, o vendedor, já no processo, podia chamar por sua vez o titular do direito anterior ou

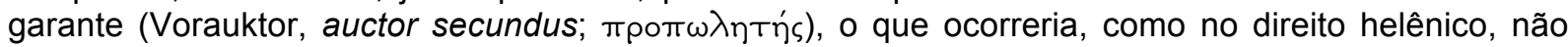
em virtude da lei, mas do costume. O garante era aquele que teria mais idoneidade para provar a melhor procedência do direito de propriedade; ao menos "em potência", acrescentamos, ou seja, no momento da celebração do negócio. Não se pode provar, nota-o bem RABEL, que o auctor pudesse entrar no processo como parte, substituindo o comprador. Talvez apenas no direito clássico, com a constituição do vendedor como procurator in rem suam. O que se poderia saber é que o mancipio dans tinha (i) de aparecer no processo; (ii) aceitar a representação do comprador; e (iii) levá-lo à vitória

${ }_{172}$ Corso di diritto romano - vol. II.2, p. 144.

${ }^{173}$ Le rôle de l'auctoritas dans la mancipatio cit., p. 603 e ss.
} 
esta é adquirida pelo pagamento de um preço. ${ }^{174} \mathrm{~A}$ auctoritas estaria na aprovação ou ratificação que o vendedor dá a esse ato: probare quod agitur; hoc est enim auctorem fieri.

Assim, para DE VISSCHER, a auctoritas não é o ato de assistência do vendedor ao comprador que tem contra si uma reivindicação de terceiro, como afirmou GIRARD, nem o dever ou obrigação de a prestar; ela será, em sentido técnico e geral, a confirmação ou ratificação dada pelo vendedor a essa declaração unilateral de aquisição: HUNC EGO HOMINEM EX IURE QUIRITIUM MEUM ESSE AIO, etc. Essa ratificação teria eficácia absoluta, erga omnes. ${ }^{175}$

Desse modo, a auctoritas será o fundamento da totalidade dos efeitos do ato da mancipatio; ou seja, a sua causa. ${ }^{176}$

A noção de auctor como "aquele de quem adquirimos uma coisa» aparece aplicado à mancipatio algumas vezes no Digesto, ${ }^{177}$ mas também ao possuidor precedente na accessio temporis e em geral àquele que «me» transferiu um direito, a quo ius in me transit. ${ }^{178}$ De resto, segundo nossa própria investigação, a palavra auctor aparece, em todas as suas declinações, 274 vezes na compilação de Justiniano.

Mas são dois os fragmentos mais importantes, nos quais se dá o nome de auctor ao mancipio dans: Paul. 5 ad. Sab., D. 19, 1, 4, 1; $;^{179}$ e, secundariamente, Scaev. 7 dig., D. 19, 1, 52, 3. ${ }^{180}$

O raciocínio do romanista é claro: se o caso de Paulo versa sobre um litígio apenas entre as partes da mancipatio - envolvendo aquisição do domínio -, sem assistência de nenhum tipo, e sendo o mancipio dans chamado auctor, logo um dos efeitos da auctoritas é o de mera aquisição. ${ }^{181}$ Isso se confirma recorrendo-se ao

\footnotetext{
${ }^{174}$ Esta declaração dá início ao rito da mancipatio e determina todo o seu mecanismo, de acordo com o ponto de vista do autor (idem, p. 604).

${ }^{175}$ Idem, p. 609-610.

${ }^{176}$ Idem, p. 610.

177 Ulp. 68 ad ed., D. 43, 12, 1, 22; Ulp. 60 ad ed., D. 43, 17, 3, 4.

178 Paul. 11 ad Pl., D. 50, 17, 175, 1.

179 «Si modus agri minor inveniatur, pro numero iugerum auctor obligatus est». Na edição usada pelo romanista: invenitur.

180 «Quaero, an ripa, quae ab auctore domui coniuncta erat, ad emptorem quoque iure emptionis pertineat». Na edição do Digesto usada por DE VISSCHER está ausente a palavra domui.

${ }^{181}$ Le role de l'auctoritas, p. 612.
} 
chamado auctor secundus, ${ }^{182}$ que em alguns negócios atua como garantidor tanto da aquisição quanto da evicção. ${ }^{183}$

Além disso, vulgarmente dita, a evicção compreende não só o caso da perda da propriedade por reivindicação de terceiro, mas também o da perda ocasionada pelo próprio vendedor. ${ }^{184}$

Após um amplo exame das fontes, ${ }^{185}$ DE VISSCHER conclui que é muito difícil derivar todos esses significados da auctoritas - observados em vários vestígios da atividade romana - de um sentido estrito de «assistência contra terceiros», como fê-lo GIRARD. ${ }^{186}$

De qualquer modo, DE VISSCHER se alinha a MOMMSEN, HUSCHKE, PERNICE e GIRARD ao teorizar sobre a auctoritas sob a perspectiva da garantia; sua concepção, entretanto, é mais ampla, e dá conta, embora sem o perceber, de uma suposta confusão dos humanistas, pandectistas e romanistas ingleses.

Mas há que fazer justiça a GIRARD. Ao censurá-lo por conceber a auctoritas de um modo demasiadamente estreito, DE VISSCHER demonstra não ter lido com atenção o seu trabalho. Pois GIRARD procurava por um significado arcaico de

\footnotetext{
182 Discute-o também E. RABEL, Die Haftung des Verkäufers wegen Mangels im Rechte cit., p. 13.

${ }^{183}$ Cf. FIRA III, n. ${ }^{\circ} 88$.

184 Ulp. 29 ad. Sab., D. 21, 2, 17: «Vindicantem venditorem rem, quam ipse vendidit, exceptione doli posse summoveri nemini dubium est, quamvis alio iure dominium quaesierit: improbe enim rem a se distractam evincere conatur».

${ }^{185}$ As fontes são interpretadas da seguinte forma: a) sobre Cic., de harusp. 7, 14, diz que iure auctoritatis se refere ao título e à aquisição, e não ao usucapião, e auctoritas ao fundamento iure privato da transferência pela mancipatio; b) sobre Cic. Top. 4, 23 e pro Caec. 19, 54, que mencionam o suposto assíndeto usus auctoritas, este é traduzido como "o regime do usus e da auctoritas», que dura dois anos, significando que durante esse tempo de prescrição aquisitiva do usucapião ele se serve da auctoritas do mancipio dans como fundamento do seu direito, o que nos leva a um sentido aquisitivo do instituto; c) usa Cic. De off., 1, 37, 11 para demonstrar o único impedimento ao usucapião e à limitação temporal ex lege da auctoritas, na verdade em prejuízo do peregrino qui suis legibus utitur (Varr. de ling. lat. 5, 3): tendo um cidadão romano reivindicação contra um peregrino que o desapossou da coisa mancipi antes do término do prazo para usucapião, interrompendo-o, ele precisa de uma auctoritas eterna - se as circunstâncias lhe impedem a aquisição de um título público (o usucapião), ele deve recorrer ao ius auctoritatis, que é título privado, para fazer valer o seu direito; d) confirma-o a lex Atinia citada em Gell. 17, 7, que assegura à pessoa que teve coisa sua furtada o sucesso numa reivindicação, recorrendo a qualquer momento à auctoritas (justamente por não ter passado o tempo do usucapião); e) uma última prova em Scaev. 5 dig., D. 13, 7, 43 pr., que se refere a um instrumentum auctoritatis, na leitura do autor uma natural redução da auctoritas ao "ato ou título de propriedade» (Le role de l'auctoritas cit., p. 617-624).

${ }^{186}$ Idem, p. 624.
} 
auctoritas, e chegou a mencionar que, com o tempo - notamo-lo acima - a palavra adquiriu sentido mais amplo, inclusive o de direito de propriedade. ${ }^{187}$

O autor moderno a defender com maior habilidade a natureza

«garantista» ou «tecnicista» da auctoritas é certamente M. KASER, que projetou novas luzes sobre os estudos de GIRARD e de VISSCHER. ${ }^{188}$

No seu estudo definitivo sobre o tema, ${ }^{189}$ KASER nota, alinhando-se a
MAYER-MALY, ${ }^{190}$ a existência de duas teorias modernas sobre a natureza da

187 L'action auctoritatis cit., p. 185. Uma prova disso é o fato de os romanos não terem empregado uma palavra para a propriedade abstrata no direito antigo, por razões óbvias. O que havia eram objetos dos quais se podia apropriar, res mancipi e res nec mancipi: fundi, agri, aedificia, etc. Proprietas, por exemplo, só aparece no período clássico (v. g. em Gai. 2, 33; 2, 90; 2, 89; 3, 136), segundo KASER, Altrömisches Eigentum und usucapio cit., p. 123, n. 3, só no séc. I ou II a.C., como conceito geral e técnico de "Zugehörigkeit», de difícil tradução para o português. A noção de jus proprietatis é moderna. $O$ que não existe é uma fonte mais antiga em que o termo auctoritas seja empregado com o sentido de propriedade, a não ser que acreditemos a interpretação dos humanistas. Expressão da propriedade romana antiga é o meum esse ex iure Quiritium (sobre a segunda parte da expressão, v. o fragm. Tudertinum em Bruns I, 32: "Quae poenae ob iura sepulcrorum violata cauta iure Quiritium etc.»). Quanto a DE VISSCHER, falta-lhe uma compreensão do desenvolvimento histórico da noção de auctoritas. As passagens do Digesto não dão conta disso; antes, são testemunha de uma fase muito posterior, contendo poucos vestígios - à exceção de alguns fragmentos - do período decenviral e pré-decenviral. No capítulo 4 , investigaremos com alguma profundidade a origem e a idéia de propriedade no direito arcaico.

${ }_{188}$ Mais antigo, mas representando de modo claro o pensamento de M. KASER, é o estudo Eigentum und Besitz im älteren römischen Recht, Weimar, H. Böhlaus, 1943; nela, o autor diz com todas as letras que auctoritas significa a garantia do alienante, «die Gewährschaft des Veräußerers» (p. 89). Na monografia Das altrömische ius cit., p. 136 e ss., KASER volta a tratar do tema, mantendo a sua opinião. Ele estuda a mancipatio em seus três estágios de desenvolvimento: originalmente, uma apropriação simples com a mão (Handgriff), manu capere, mais tarde uma compra e venda real, com pagamento de preço à vista (Austauschakt), e por fim, ainda antes das XII tábuas, um ato de transferência (Übereignungsgeschäft), uma compra e venda nummus unus, com possibilidade de se diferir o pagamento. As duas últimas formas seriam resultado do trabalho dos pontífices, e estão ligadas à evolução da propriedade segundo o esquema de KASER. O efeito da mancipatio é triplo; o primeiro deles é obrigar o vendedor a assegurar o comprador em caso de eviç̧ão (auctoritas). Ao receber o preço e não assegurar o adquirente, o alienante pratica um delito análogo ao furtum. Esses efeitos são adstritos ao que KASER chama "Auktoritätshaftung», responsabilidade pela auctoritas, existente nos primórdios do direito romano e com feição penal. Dois anos depois, KASER escreveu o artigo Neue Studien zum altrömischen Eigentum, in SZ 68, 1951; nesse estudo, o autor muda um pouco o seu modo de conceber a auctoritas, mantendo a sua defesa, todavia, da noção de auctoritas como garantia. Para ele, auctoritas passa a significar uma posição jurídica que o adquirente recebe do seu «Vormann» por ocasião da aquisição; em conseqüencia, a garantia do alienante pela posse da coisa nas mãos do adquirente contra esbulho tanto dele próprio quanto de terceiros. A regra do usus auctoritas - que será objeto de investigação em outro item - significa portanto uma proteção do possuidor que dura um ou dois anos (pp.155-156). Consideraremos o desenvolvimento da doutrina de KASER em seguida.

${ }^{189}$ Altrömisches Eigentum und usucapio cit., p. 121 e ss., apoiado em dois outros artigos, Über 'relatives Eigentum' im altrömischen Recht, in SZ 102 (1985); e Zur 'legis sacramento in rem', in SZ 104, (1987).

${ }^{190}$ Mais adiante estudaremos a sua posição. 
auctoritas: uma que a encara como garantia pela evicção, e outra que a vê como um estado ou posição jurídica, dependente ou não da mancipatio, e portanto criada ou não pelo alienante, seja ela uma posição de autoridade ou de domínio. ${ }^{191}$

Para ele, se consideramos a auctoritas decenviral, não há dúvida de que a primeira teoria é a mais adequada: a regulação do prazo prescricional (Befristung) estaria ligado a uma instituição concreta, a actio auctoritatis. Considerada como uma posição de poder, a auctoritas seria um conceito muito abstrato. $^{192}$

Ele traduz usus-auctoritas por «Gewährschaft für den Besitz». ${ }^{193}$ Auctoritas seria a própria garantia; ${ }^{194}$ como vimos no capítulo anterior, propriedade de quem é auctor, garante.

K. F. ThORMAnN definiu a auctoritas do ponto de vista da responsabilidade (auctoritas-Haftung) ou dever (auctoritas-Verpflichtung) para com o adquirente, que se instaura como conseqüência da transferência ou criação (Urheberschaft) da propriedade mediante o pagamento do preço no rito da mancipatio. ${ }^{195}$

Essa responsabilidade, pela sua própria natureza, é de garantia do alienante pela transferência da propriedade. ${ }^{196}$

V. ARANGIO-RUIZ considerou com vagar o tema da auctoritas no seu tratado sobre a compra e venda, ${ }^{197}$ examinando as fontes mais importantes para a reconstituição deste instituto à luz da doutrina de P. F. GIRARD e dos autores que o seguiram em parte.

\footnotetext{
${ }_{191}^{19}$ Altrömisches Eigentum und usucapio cit., p. 128.

192 Idem, ibidem. O seu argumento é nesse sentido: não se compaginaria com um direito realista e concreto algo como a limitação temporal de uma «posição de poder».

${ }^{193}$ A polêmica sobre a tradução dessa regra será objeto de estudo em um item à parte. É importante notar que na primeira edição de Das römische Privatrecht, 1 . $^{a}$ parte, München, Beck'sche, 1955, p. 118, KASER concebia a auctoritas como uma posição jurídica, "Rechtsposition», conferida pelo alienante ao adquirente.

${ }_{194}$ Sobre as fontes e os efeitos da auctoritas segundo KASER, v. os próximos itens. Aqui só nos importa a definição da natureza da auctoritas, sem maior detalhamento.

${ }^{195}$ Auctoritas cit., p. 75 e ss.

196 Idem, pp. 54-55.

197 La compravendita in diritto romano, vol. II, Napoli, Jovene, 1954, p. 310 e ss.
} 
A sua conclusão é que a auctoritas teria, mesmo etimologicamente, o sentido de garantia, assistência, como nos outros casos (tutoris, patrum). ${ }^{198}$ Entretanto, para ele, a afirmação contida na fórmula conservada por Val. Prob. 4, 7, apesar de se referir à assistência que o vendedor devia dar ao comprador, era feita pelo terceiro reivindicante, e não pelos que celebraram a mancipatio. E o vendedor, longe de substituir o comprador no processo do terceiro contra o comprador, assumiria apenas uma posição de segundo plano.

Examinados brevemente esses autores, podemos classificar da seguinte forma as posições "garantistas» sobre a natureza da auctoritas decenviral:

1) Responsabilidade ou obrigação (Verpflichtung) diante da não transferência da coisa pelo mancipio dans (MOMMSEN, HUSCHKE);

2) Estado ou posição que permite ao auctor continuar, em virtude da venda, obrigado a garantir o comprador nos casos de contestação da sua posse (HEINZE);

3) Assistência concreta que o mancipio dans presta ao mancipio accipiens em caso de reivindicação de terceiro (GIRARD, LENEL, ARANGIO-RUIZ);

4) Propriedade do auctor, mancipio dans, pela qual ele serve de autor, originador, da aquisição pela mancipatio, suportando o periculum iudicii caso tenha convencionado uma particular nuncupatio nesse sentido (KARLOWA);

5) Dever de garantia do mancipio dans, ou seja, de defender o comprador ativa e passivamente diante de uma pretensão de terceiro à coisa (RABEL);

6) Confirmação ou ratificação dada pelo vendedor à declaração unilateral de aquisição do adquirente mancipio accipiens (DE VISSCHER);

7) Simples garantia ou responsabilidade pela evicção, «Gewährschaftshaftung», decorrente da mancipatio (PERNICE, BONFANTE, KASER, MAYER-MALY);

198 Idem, p. 313. 
8) Responsabilidade ou dever do mancipio dans para com o adquirente como conseqüência da transferência da propriedade mediante o pagamento do preço na mancipatio (THORMANN).

\subsection{Fundamento das teorias "garantistas»}

Esses autores se apoiaram em pressupostos e raciocínios comuns, elaborados a partir das fontes romanas e de teorias inspiradas na moderna civilística.

A ênfase dessa posição está na seguinte situação: $A$ adquire uma coisa de $B$ por mancipatio; $C$, julgando-se o verdadeiro dono, reclama-a para si junto a $A ; A$ recorre a $B$ a fim de que o socorra. A auctoritas é qualidade do auctor $(B)$, que, ao entregar formalmente a coisa, assume a responsabilidade pela eficácia do negócio do ponto de vista da transferência da propriedade (meum esse). Caso não preste assistência, ou fique provado que não era senhor da coisa, $B$ responde pelo dobro do valor do negócio - pago durante o ritual da mancipatio - , caso $A$ o acione lançando mão da actio auctoritatis. Para a maioria dos autores, a auctoritas dura um ou dois anos, e depois deixa de existir: com o término desse prazo, $A$ adquire a propriedade quiritária e pode prescindir da assistência de $B$.

Pergunta-se pelos fundamentos dessa tese, já que não há, em todo o corpus textual jurídico romano que nos foi transmitido, uma formulação suficientemente clara, que permita ao estudioso deduzir, sem sombra de dúvida, que esse era exatamente o conteúdo e o funcionamento prático da auctoritas rerum entre os romanos, como instituto de direito privado já presente nas XII tábuas.

Os autores que em maior profundidade lançaram as bases dessa tese são Mommsen, Huschie, GiRARd, Lenel, Mayer-Maly e Kaser.

O trabalho de MOMMSEN, muito pouco estudado pelos autores contemporâneos, traz em germe todos os desenvolvimentos das teorias «garantistas». 
O romanista defende que auctor é aquele que deve «evictionem praestare», ${ }^{199}$ e auctoritas a "conditio eius, qui quia mancipavit vendiditve ad evictionem vitiaque praestanda obligatio est». ${ }^{200}$ Essa posição contraria a interpretação tradicional, ${ }^{201}$ segundo a qual auctoritas seria domínio, direito de propriedade (auctor = is qui me dominum fecit); ${ }^{202}$ esta seria, na verdade, apenas uma acepção vulgar da palavra, ${ }^{203}$ como no uso auctor $=$ is qui me genuit.

MOMMSEN, nesse sentido, reportou-se - em parte com base no trabalho dos pandectistas, comentadores e glosadores - às fontes que, mais tarde, tornar-seiam topoi do discurso sobre a auctoritas. Propomo-nos explicitar brevemente essas fontes e o caminho trilhado pelo autor; o mesmo faremos com os que se the seguiram.

Após indicar passagens em que a significação técnica do vocábulo é «Usurpada», ${ }^{204}$ MommSEn alude a duas passagens de Cícero: Top. 10, 45 e Pro. Mur. 2, 3. Na primeira delas, Cícero considera a hipótese de alguém que deu em mancipio uma coisa nec mancipi, ${ }^{205}$ e pergunta-se se o vendedor, em razão disso, ficou

\footnotetext{
${ }^{199}$ De auctoritate commentatio cit., p. 458.

200 Idem, p. 459.

201 Essa mudança de opinião, da visão tradicional para a moderna, ocorreu justamente em virtude de uma análise crítica das fontes, consolidando-se uma posição que já se esboçava entre os humanistas (e com CUJÁcIO, no séc. XVII). A visão moderna, entretanto, especialmente a de MOMMSEN, basea-se não em fontes arcaicas - que praticamente não existem, com exceção das XII tábuas -, mas em escritos do período clássico e pós-clássico

${ }^{202}$ Todavia, há que notar que supostamente garante contra a evicção não só o proprietário, mas também o auctor secundus, uma espécie de fiador, caso convencionado. A figura é mencionada pelas fontes, a exemplo de Ulp. 30 ad ed., D. 21, 2, 4 pr: «lllud quaeritur, an is qui mancipium vendidit debeat fidejussorem ob evictionem dare, quem volgo auctorem secundum vocant». Aliás, o uso da expressão auctor secundus por Ulpiano prova que vulgarmente a auctoritas estava associada - ao menos no período clássico, se julgamos que a fonte está livre de interpolações - à garantia contra a evicção e à mancipatio. Pelo consta, esse é o único texto em que aparecem as palavras auctor, evictio e mancipium no mesmo contexto - algo que, ao que parece, não foi notado nem pelos "garantistas» nem pelos que sustentam teorias «generalistas» sobre a auctoritas.

${ }^{203}$ O autor lembra a concepção de SALMASIUS, pouco conhecida, de auctoritas como domínio in bonis (em De usuris, interpretando Cic. de harusp. 7, 14).

204 Especialmente Plaut. Trin. 1, 2, 180, em que auctoritas se aplica à autoria de um dano (o responsável é chamado a ressarci-lo); Sen. nat. quaest. 4, 3, 2, que usa a expressão auctoritatem promittere, assim como aparece em Pap. Vat. 10; ou ainda quando adquire o sentido de actio de evictione em Venul. 17 stipul., D. 21, 2, 76 ou de domínio em Cic. de harusp. 7, 14.

${ }^{205}$ Alguns autores crêem que Cícero se refere a coisas sacras ou de outra pessoa (venda non domino); MOMMSEN acredita que não, já que, nessa hipótese, a venda nunca era impune (nequaquam impunis erat).
} 
obrigado; ${ }^{206}$ na segunda, o autor diz que quem dá em mancipio responde pelo periculum iudicii, já que se obrigou pelo nexum, fazendo uma comparação com o cônsul: tanto um como o outro fazem um benefício a alguém e ao mesmo tempo são responsáveis como auctores. ${ }^{207}$ Conclui então o jurista que auctor é aquele que assume a obrigação de responder pelo risco que sofre o mancipio accipiens de perder a coisa em juízo. ${ }^{208}$

A causa dessa obrigação estaria provada pela dicção da lei das XII tábuas: «CUM NEXUM FACIET MANCIPIUMQUE, UTI LINGUA NUNCUPASSIT ITA IUS ESTO» (VI, 1) ${ }^{209}$ O mancipio dans devia observar o que foi dito mancipio; ${ }^{210}$ caso contrário, respondia pelo dobro, o que estaria demonstrado em Cic. de off. $3,16,65 .{ }^{211} \mathrm{E}$ isto estaria diretamente ligado ao segundo texto de Cícero citado acima: a expressão qui nexu se obligavit referir-se-ia ao nexum mancipiumque das XII tábuas.

Isso seria por sua vez confirmado por um texto jurídico posterior, PS. 2, 17, 3: «Res empta mancipatione et traditione perfecta si evincatur, auctoritatis venditor duplo tenus obligatur», que se aplica às coisas mancipi (das res nec mancipi cuidaria o § 2); e também pela fórmula processual «QUANDO IN IURE TE CONSPICIO POSTULO ANNE FUAS AUCTOR», conservada pelo compêndio de Val. Prob., De not. iur. $4,7$.

Por fim, além dos textos de Cícero, provariam que a mancipatio está ligada à auctoritas algumas passagens de Plauto: Curc. 4, 2, 12; Pers. 4, 3, 55-56; 4, 4,40 . No segundo texto, teríamos um forte indício: "Suo periculo is eam emat qui

206 «Finge mancipio aliquem dedisse id quod mancipio dari non potest; num idcirco id eius factum est qui accepit? Aut num is qui mancipio dedit ob eam rem se ulla re obligavit?».

${ }^{207}$ "Quodsi in iis rebus repetendis, quae mancipi sunt, is periculum iudicii praestare debet, qui se nexu obligavit, profecto etiam rectius in iudicio consulis designati is potissimum consul, qui consulem declaravit, auctor beneficii populi Romani defensorque periculi esse debebit».

${ }^{208}$ De auctoritate commentatio cit., p. 460.

209 Talvez MOMMSEN e quase todos os autores que trataram da mancipatio - especialmente O. KARLOWA - não tenham se lembrado do texto de Cincius, lurispr. 8, que corrobora a idéia de que a expressão UTI LINGUA etc. se refere não só ao que foi dito como que em um pacto anexo (o que aliás muitos julgam improvável de ter ocorrido no período arcaico), mas precipuamente ao que é dito no próprio rito, especialmente o valor do negócio: «Nuncupata pecunia est... nominata, certa, nominibus propriis pronuntiata. 'Cum nexum faciet mancipiumque, uti lingua nuncupassit, ita ius esto', id est, uti nominarit locutusve erit, ita ius esto».

${ }^{210}$ Ou seja - embora MOMMSEN não o explicite -, a afirmação «HUNC EGO [HOMINEM, v. g.] EX IURE QUIRITIUM MEUM ESSE AIO» (Gai. 1, 119).

${ }^{211}$ «Ex XII satis erat ea praestari quae essent lingua nuncupata, quae qui inficiatus esset, dupli poenam subibat». 
mercabitur; mancupio neque promittes neque quisquam dabit». No caso de coisas nec mancipi, transferidas por traditio, o comprador estava desprovido de qualquer garantia, a não ser que se estipulasse em dobro (stipulatio duplae); o que se provaria com Varr. de re rust. 2, 10, 5: «In servorum emtione solet, si mancipio non datur, dupla promitti, aut, si simpla pacti, simpla». ${ }^{212}$

Só depois de extrair essas conclusões das fontes citadas é que MOMMSEN passa a interpretar a regra do usus-auctoritas contida na lei das XII tábuas (VI, 3). Segundo ele, o texto quer dizer o seguinte: «Fundo per biennium emtor utatur, venditor tamdiu auctoritatem ei accommodet evicionemque praestet; in ceteris rebus annus pro biennio observetur». ${ }^{213}$ Portanto, o fragmento não versaria sobre usucapião, a não ser indiretamente ${ }^{214}$ o efeito previsto é que, durante esse tempo de um ou dois anos em que o comprador tem o usum da coisa, o vendedor presta-lhe a auctoritas - vindo, se necessário, a intervir (um dos sentidos de do verbo accommodo, usado por MOMMSEN) -, protegendo-o de eventual eviç̧ão.

Eis, em resumo, a interpretação de MOMMSEN.

G. HUSCHKE apoiou-se explicitamente nas mesmas fontes, ${ }^{215}$ fazendo menção ao trabalho de MOMMSEN, mas formulou uma teoria diferente, com enfoque no nexum.

Entre os negócios jurídicos que se podia realizar através do nexum, segundo o testemunho das fontes, ${ }^{216}$ estava a compra. Isso se fazia pela mancipatio, com a entrega do aes, o pagamento do preço ${ }^{217}$ e uma transferência de propriedade

\footnotetext{
${ }^{212}$ De auctoritate commentatio cit., p. 462.

${ }^{213}$ Idem, p. 463.

${ }^{214}$ MOMMSEN acrescenta que seria estranho que auctoritas significasse justamente um instituto que pressupõe a libertação do auctor, do alienante. Além disso, a tábua VI, segundo a ordem de DIRKSEN, começa falando do nexum e da mancipatio.

${ }^{215}$ Cf. Über das Recht des Nexum... cit., p. 171-172, n. 258: PS. 2, 17, 3; Plaut. Curc. 4, 2, 8; Plaut. Pers. 4, 3, 55; Varr. De re rust. 2, 10, 5; Cic. Top. 10, 45; Cic. pro Mur. 2, 3.

${ }^{216}$ Varr. De ling. lat. 7, 105; Fest. 165. Entre outros, cf. E. SCHÖNBAUER, Mancipium und nexus, in lura 1 (1950), pp. 300-305; O. BeHRENDS, La mancipatio nelle XII tavole, in lura 33 (1982), pp. 46-103.

217 Julgamos que a dissociação entre pagamento do preço e o aes entregue durante o ritual da mancipatio passou a ocorrer tardiamente, com a possibilidade de se realizar um negócio nummo uno, ou seja, a entrega simbólica de um sestércio e o pagamento feito fora da cerimônia. Por que a entrega de um sestércio e não a ausência dele? O problema não é enfrentado diretamente pela doutrina, mas é possível que, em se tratando de uma gestio per aes et libram, a falta de um elemento essencial embora de valor meramente formal - invalidaria o negócio, assim como no caso da ausência de
} 
de natureza pública; para HUSCHKE, a mancipatio seria portanto como que um ato bivalente, ao mesmo tempo obrigacional e real (nexi traditio), ou seja, um «realer Verbal-Contract», sem necessidade de especial nuncupatio. ${ }^{218}$

A primeira obrigação que traz consigo o mancipium é a entrega da coisa, segundo as palavras do formulário, ditas pelo comprador: EAQUE (RES) MIHI EMPTA ESTO TOT ASSIBUS HOC AERE AENEAQUE LIBRA; a segunda, a garantia contra a eviç̧ão (Evictionsleistung), fundada também no nexum.

HUSCHKE prova a existência dessa garantia e da ação correpondente (a actio auctoritatis) - como efeitos diretamente procedentes da mancipatio - com as mesmas fontes citadas por MOMmSEN, a começar por PS. 2, 17, 3. As palavras de Plauto (Pers. $4,3,55$ ) demonstrariam que o que faz o vendedor pode ser descrito como mancipio promittere. Se não quiser garantir a procedência da coisa, basta não realizar stipulatio ou mancipatio, entregando a coisa por mera traditio (segundo a sua interpretação de Varr. de re rust. 2, 10, 5). Reforçariam essa posição Cic. Top. 10, 45 e pro Mur. 2, 3.

Segundo o testemunho de Plauto, ainda, temos o nome auctor, que se aplica ao vendedor mancipio dans que transfere a propriedade ou, não a tendo possivelmente transferido, passa a ter o dever de assistir o comprador em juízo (a auctoritas), na hipótese do seu questionamento: «sobald inm die Sache aus dem vor der Mancipation schon vorhandenen Rechte eines Dritten an derselben abgestritten wird». ${ }^{219}$ Esse direito - ius auctoritatis - é efetivado por uma suposta, porque carente de fontes diretas, ${ }^{220}$ actio auctoritatis.

Essa defesa processual por parte do auctor, chamado ao processo (auctorem laudare, Denunciation), está fundada no nexum: um vínculo obrigacional, portanto. Ocorrendo a recusa do auctor em auxiliar o comprador evicto, ou,

testemunhas ou de balança. Junte-se a isso o caráter justificadamente formalista e conservador do direito romano.

218 Über das Recht des Nexum... cit., p. 173. «Realer Verbal-Kontrakt» na ortografia atual.

${ }^{219}$ Idem, p. 180. Quando faz apenas uma tradição da coisa, o vendedor não é auctor, pois não garante optimo iure a procedência da coisa.

${ }^{220}$ Ao contrário do que ocorre com a duplae stipulatio e com a actio empti, cujas fontes dão conta do seu exato conteúdo. P. F. GIRARD, como veremos em maior detalhe adiante, foi o primeiro a estudar a fundo a suposta evolução da proteção contra evicção da actio auctoritatis à actio empti, firmando a tradição «garantista». 
comparecendo ao processo, negue aquele a sua auctoritas diante do pretor, poderá o adquirente recorrer às testemunhas da mancipatio - o que levará o auctor a ser considerado confesso in iure. As três hipóteses justificam o recurso à actio auctoritatis, de natureza pública, por parte do comprador. ${ }^{221}$

Neste contexto é que faria sentido o preceito das XII tábuas, a regra do usus-auctoritas, tal como o entende HUSCHKE. Uma maneira de o auctor livrar-se do dever de assistência via substituição processual (Vertretungsverpflichtung) era recorrer ao direito do próprio comprador de manter consigo a coisa, após um ou dois anos de usus acompanhado de auctoritas. Diversamente de MOMMSEN, HUSCHKE coloca ênfase numa espécie de proto-usucapião.

Com os estudos de P. F. GIRARD, essa tradição irá consolidar-se ainda mais. A essa altura, percebe-se que os autores não têm uma preocupação muito grande em demonstrar os fundamentos da tese "garantista», que já parece inatacável. ${ }^{222}$

Com efeito, para GIRARD ${ }^{223}$ o ponto de partida é uma fonte tardia, PS. 2, 17, 3; pois à época a mancipatio era apenas um dos modos de se transferir a propriedade. Muitos já se enganaram quanto à frase de Paulo: «auctoritatis venditor duplo tenus obligatur»; mas a dicção é bastante simples, e GIRARD nem sequer a questiona. Dela se extrai que o vendedor fica obrigado até o dobro do valor do negócio em virtude da auctoritas.

Em seguida GIRARD procura uma definição fixa, precisa e técnica dessa palavra, partindo de auctor, que a precede. A pesquisa inicial sobre esse termo é

${ }^{221}$ Idem, p. 185-186. HUSCHKE vai bastante longe quanto na sua formulação: não se limita a dizer o que está expresso - mesmo indiretamente - nas fontes, mas constrói, como quase todos os autores que partilham essa concepção, todo um sistema, semelhante ao da moderna pandectística. Isso leva a pensar, embora isso não seja necessariamente um erro, na enorme influência da civilística alemã sobre o direito romano, mesmo sobre o direito arcaico do séc. $V$ a. $C$. Mais ainda, a interpretação pandectista está dotada, como sabemos, de forte recursividade: a dogmática alemã foi construída com base no direito romano, e este, por sua vez, é como que uma reformulação com base na primeira.

${ }^{222}$ Por exemplo, L. WENGER, Die Quellen des römischen Rechts cit., p. 117, n. 80: «Auctor ist der zu Gewährschaft verpflichtete Verkäufer». Entretanto, como veremos, da metade do século XX para cá, a teoria "garantista» - malgrado continue intacta nos manuais e nas cátedras - tem sido amplamente questionada, algo que nunca teria sido imaginado por MOMMSEN, GIRARD e HUSCHKE. Em contraposição, o funcionamento da responsabilidade por evicção no período justinianeu (e possivelmente também no clássico) é amplamente descrito pelas fontes, especialmente pelo livro 21 do Digesto, sob o título «De evictionibus et duplae stipulationibus».

${ }^{223}$ L'action auctoritatis cit., p. 181. 
pobre, pois ele somente se refere a uma passagem do Digesto (Ulp. 30 ad ed., D. 21, 2, 4 pr), que menciona o auctor secundus, ou seja, o que garante a venda sem transferir ele mesmo a propriedade; e pontifica que se trata, positivamente, ou seja, quando o vendedor tem a propriedade, de «aquele de quem recebemos a propriedade». ${ }^{224}$

A auctoritas aparece negativamente na expressão «auctoritatem defugere» em Plauto, Terêncio, Cícero e no Digesto, e seria o ato do vendedor que não garante o comprador, causando-lhe inquietação. À primeira vista, em outras ocorrências - Sen. nat. quaest. 4, 3; rubrica V de PS. -, significaria a obrigação de garantia que o vendedor assume em caso de evicção (auctoritatem promittere ou contrahere); o direito a essa garantia seria o auctoritatem stipulari, famoso hapax legomenon de Pap. Vat. 10. Mas auctoritas pode ser apenas um modo de transferência da propriedade, como em Cic. de harusp. 7, 14: «iure auctoritatis».

Mas o significado mais antigo de auctor, mais concreto e mais próximo da etimologia (augere) seria o daquele que intervém numa situação para completar, fortificar a situação de alguém; no caso da mancipatio, aquele que assiste o adquirente no processo de reivindicação de terceiro movido contra ele. E auctoritas seria não um modo de adquirir, e nem uma obrigação de garantia, mas o ato concreto de assistência. ${ }^{225}$

Com essa idéia, GIRARD dá mais um passo, indo mais longe do que MOMMSEN e HUSCHKE, não obstante manter-se na mesma tradição. O fundamento dessa teoria está principalmente em uma fonte já utilizada pelos autores mais antigos: Val. Prob. 4, 7. O raciocínio é inteligente, pois se trata de uma fonte relativamente antiga e, ao mesmo tempo, em certo sentido jurídica, por estar contida em um formulário processual relativo às legis actiones.

\footnotetext{
${ }^{224}$ Idem, p. 182.

${ }^{225}$ Quase à mesma época, LEIST, Auctoritas, in RE 4, p. 2275, sustentou doutrina semelhante, referindo-se à auctoritas na mancipatio como «Beistand und Beistandpflicht des Mancipanten».
} 
A assistência do auctor não melhora ou incrementa - tendo-se em mente o verbo augeo - a mancipatio, mas sim a situação do defensor no processo de reivindicação, semelhantemente ao que ocorre com a auctoritas tutoris. ${ }^{226}$

Nesse contexto é que estaria a regra do usus-auctoritas: limitar temporalmente - como mais tarde definirão MAYER-MALY ${ }^{227}$ e KASER ${ }^{228}$ - a assistência do auctor.

GIRARD explica que a palavra passou a significar mais tarde a obrigação de prestar essa assistência; em seguida, o ato translativo de propriedade em razão do qual essa obrigação se produziu; e finalmente toda aquisição de propriedade e o próprio direito de propriedade. ${ }^{229}$

É sobre esse fundamento - o único ponto que nos interessa - que GIRARD construirá o seu detalhado sistema.

Os mesmos pressupostos foram utilizados por LENEL, ${ }^{230}$ que tinha diante de si o trabalho de GIRARD. ${ }^{231}$ Ele afirmou existir, no título XLV, § 290, do Edito

${ }^{226}$ Para defender que o sentido etimológico de auctor = is qui auget aplica-se à situação do adquirente, e não à própria mancipatio - pois isso equivaleria a dizer que seria necessário pactuar um dever de assistência, que implicaria um acréscimo (um augere) ao próprio negócio -, é necessário, segundo GIRARD, entender o verbo postulo como tendo o sentido de requerer, e não um sentido interrogativo; isso porque, caso fosse uma pergunta, a fórmula indicaria a possibilidade de se pactuar ou não o dever de assistência. Sendo uma chamada, um requerimento, a fórmula indicaria, ao contrário, que quem melhora a situação do adquirente é o auctor, e não a mancipatio. Em Plauto, por exemplo, postulo tem quase invariavelmente o sentido de «requerer»: «Postulo abs te, ut mi illum reddas servum» (Capt. 5, 1); «Et ius et aequom postulas» (Stich. 3, 1). A fórmula «postulo, anne dicas, qua ex causa vindicaveris» tem um esse sentido de "sommation», próximo ao da sentença conservada por Cícero e Valério Probo: o interessado não pergunta ao mancipio dans se ele quer assumir a posição de auctor, mas sim demanda que ele o seja (L'action auctoritatis cit., p. 185). A tese de GIRARD é que isso era dito na ação reivindicatória, e não na actio auctoritatis, como sustentou MOMMSEN; e ele tem razão em afirmá-lo, já que Cícero coloca próxima ao "Quando te in iure conspicio» a fórmula reivindicatória «anne tu dicas qua ex causa vindicaveris» (pro Mur. 26, 20), dando a entender que pertencem ao mesmo gênero de ação in rem (no mesmo sentido, A. PERNICE, Labeo cit., p. 115). Resta ainda observar que o auctor, na teoria de GIRARD, não assiste o adquirente por benevolência; é justamente a possibilidade do auctor sofrer uma auctoritatis actio que serve de motivo para a sua assistência, a título de coerção (idem, p. 190).

227 Altrömisches Eigentum und usucapio cit., p. 129. Cf. também, W. KUNKEL/T. MAYER-MALY, Römisches Recht cit., pp. 173-174, para uma reinterpretação contemporânea.

${ }^{228}$ Neue Studien zum altrömischen Eigentum cit., p. 148.

${ }^{229}$ L'action auctoritatis cit., p. 185.

230 Embora discuta em profundidade apenas fragmentos do Digesto - outras fontes são citadas apenas de passagem (cf. Das Edictum Perpetuum cit., p. 543, n. 6) -, a especulação de LENEL não faria sentido sem a interpretação das fontes feita por MOMMSEN, HUSCHKE, GIRARD e outros autores. Ela serve como possível demonstração a posteriori da teoria garantista, que se pauta, segundo nossa opinião, especialmente em Paulo, Cícero, Plauto e nas XII tábuas: embora tenha deixado de existir no direito justinianeu, o sistema da actio auctoritatis teria deixado nele, de forma velada, alguns vestígios. 
perpétuo, ${ }^{232}$ uma secção destinada à auctoritas, denominada De auctoritate. A rubrica aparece em itálico por ser um nome provável dado pelo autor, ausente qualquer referência expressa a ele. ${ }^{233}$

Ele dá como fontes: Ulp., 80-81 ad ed.; ${ }^{234}$ Paul., 76-77 ad ed.; ${ }^{235}$ Gai., 28 ad ed. prov.; ${ }^{236}$ Julian., 57-58 dig.; ${ }^{237}$ Cels., 27 dig.; ${ }^{238}$ Papin., 28 quaest. ${ }^{239}$

Ulpiano e Paulo não tratam apenas da evicção nos dois livros citados, mas Juliano se dedica integralmente ao tema no livro 57, fazendo-o todavia parcialmente no livro 58. Para LENEL, não se tratava aqui originalmente de uma ação (Rechtsmittel) de defesa contra a evicção, mas de duas. Pois nos comentários e

${ }^{231}$ Idem, p. 543, n. 4. Além de GIRARD, o autor se reporta a M. BECHMANN, e em menor monta a A.
PERNICE e E. DANZ, cuja apreciação das fontes parece-nos insuficiente. Posteriormente, A. PERNICE
por sua vez apoiou-se em LENEL e GIRARD (Labeo... cit., p. 115, n. 3), em um claro exemplo de
interpretação circular.
${ }^{232}$ O autor dá como fontes e fundamento para a reconstituição do Edito os libri ad edictum praetoris
de Ulpiano e Paulo, bem como os libri ad edictum provinciale de Gaio. Como auxiliares, os libri
brevium de Paulo, os libri ad edictum urbanum de Gaio, bem como os comentários de Pompônio,
Calístrato e Furius Anthianus. São úteis também, embora menos importantes, os demais escritos
pertinentes citados no Digesto. A ordem das matérias do Edito é a mesma seguida mais tarde pelo
Digesto. Trata-se sobretudo de uma ordenação processual, em certo sentido, contendo aquilo que
Gaio chamava de ius quod ad actiones pertinet (pp. $3-7$ e 15). Essa reconstrução tem sido
tradicionalmente reputada como sendo da mais alta autoridade (um dos primeiros a apoiá-lo foi o próprio P. F. GIRARD, L'edit perpetuel, in NRH 28 (1904), p. 117).

${ }^{233}$ Das Edictum Perpetuum, p. 542.

${ }^{234}$ Pal. II, fr. 1741-1745. O livro 80 começa falando de stipulationes e, a partir desse fr. 1741, abre-se um suposto subtítulo «De auctoritate». Eis o que anota LENEL sobre a possibilidade de interpolação nesses trechos de Ulpiano: «Verisimile est Ulpianum hac libro ex professo non de stipulatione pro evictione interposita egisse, sed de auctoritatis actione... Nec tamen crediderim in omnibus quae sequuntur fragmentis stipulationis mentionem deberi Triboniano, cum facile fieri potuerit, ut Ulpianus stipulationis ius in auctoritatis actionis comparationem his locis attingeret» (Pal. II, p. 880, n. 3). As interpolações estariam todas no fr. 1743: evictio em lugar auctoritas, actio de evictione em lugar de actio auctoritatis. A exposição sobre a auctoritas continuaria no livro 81, até o fr. 1745.

${ }^{235}$ Pal. I, fr. 826-828. O livro 76 começa no meio tratando da auctoritas, e o livro 77 tem apenas um fragmento sobre o mesmo tema. Há interpolação no fr. 826, actionem pro evictione (auctoritatem). A do fr. 828, tradito por mancipato, parece, mesmo para LENEL, duvidosa.

${ }^{236}$ Pal. I, fr. 367-368. A exposição sobre a auctoritas vai do início ao meio do livro 28. O fr. 367 diz: "Ut res emptoris fiat, nihil interest, utrum solum sit pretium an eo nomine fideiussor datus sit». Comparar com PS. 2, 17, 1.

${ }^{237}$ Pal. I, fr. 735-738. Começa no livro 57 e vai até quase o final do livro 58, sem interrupção. No fr. 735 , são interpolações as palavras evictionem (auctoritatem), tradendo (mancipio), etc; duvidosa a interpolação em de evictione stipulationem (de auctoritate actionem). Curioso é o fr. 737: "Si is qui satis a me de evictione...». LENEL propõe: "Si is qui satis a me secundum mancipium».

${ }^{238}$ Pal. I, fr. 231-234. A exposição se inicia no meio do livro 28 e vai até o final. LENEL anota ao fr. 232 que na sua redação presente em Cels. 28 dig., D. 21, 2, 10 parece tratar de transferência in iure cessio e evicção: "Sed Celsum suspicor non de in iure cessione et evictione, sed de mancipatione et auctoritate agisse».

${ }^{239}$ Pal. I, fr. 349-350. Trata-se dos dois últimos fragmentos do livro 28; o longo fr. 329 trataria, entre outras, da actio auctoritatis, e não da actio de evictione. 
Ulpiano e Paulo, bem como no de Juliano, é improvável que a discussão sobre uma e mesma ação ter-se-ia iniciado no meio de um livro e então interrompida e retomada num trecho do outro livro.

Acrescentamos, para aclarar, que seria mais lógico que esses juristas esgotassem o tratamento do assunto sem interrupções; a estranheza é maior levando-se em conta que três comentadores o fizeram. A discussão sobre a stipulatio duplae e a ação correspondente não ocorre nesses trechos, pois esse remédio legal estava sem dúvida contido no edictum aedilis. ${ }^{240}$

Eliminando-se a possibilidade da stipulatio duplae, só restam dois remédios que poderiam ser versados originalmente nesses trechos, por cuidar de evicção: a actio auctoritatis e a satisdatio secundum mancipium. A actio auctoritatis seria assunto de Ulp. 80, Paul. 76, Gai 28 e Julian. $57 .^{241}$

LENEL procura não discutir a doutrina da actio auctoritatis, apoiando-se em Bechmann e GIRARD. Como prova do dever do mancipio dans de fornecer garantia in duplum ao accipiens, refere-se a PS. $2,17,3,{ }^{242}$ e a PS. $2,17,1 .{ }^{243}$

O que nos interessa é a discussão que faz no âmbito das interpolações. Para ele, a sua existência é inquestionável em vários dos trechos citados.

Ele começa com uma passagem de Julian. 57 dig., fr. 39 (colhido em D. $21,2,39) .{ }^{244}$ Diz ser evidente que em lugar de tradere estava mancipare, em lugar de evictionis nomine estava escrito auctoritatis nomine e que antes de defugiet havia a palavra auctoritatem. Reconstruído, o fragmento faz bastante sentido no contexto da teoria da auctoritas-Haftung.

\footnotetext{
${ }^{240}$ Pomp. 26 ad. Sab., D. 45, 1, 5: «...duplae stipulatio venit ab iudice aut ab aedilis edicto».

${ }^{241}$ Edictum perpetuum cit., p. 542-543.

242 «Res empta mancipatione et traditione perfecta si evincatur, auctoritatis venditor duplo tenus obligator».

${ }^{243}$ «Venditor si eius rei, quam vendidit, dominus non sit, [pretio accepto] auctoritatis manebit obnoxius: [aliter enim non potest obligari]».

${ }_{244}$ "Qui statu liberum tradit, nisi dixerit eum statu liberum esse, evictionis nomine perpetuo obligatur. Qui servum venditum tradit et dicit usum fructum in eo Seii esse, cum ad Sempronium pertineat, Sempronio usum fructum patente perinde tenetur, ac si in tradendo dixisset usus fructus nomine adversus Seium non teneri et si re vera Seii usus fructus fuerit, legatus autem ita, ut, cum ad Seium pertinere desisset, Sempronii esset, Sempronio usum fructum patente tenebitur, Seio agente recte defugiet».
} 
Em outro parágrafo do mesmo fragmento, ${ }^{245}$ aponta que onde lemos acceperas e tradiderat estava sem dúvida mancipio acceperas e mancipio dederat. Mais interessante é o princípio do fragmento: ${ }^{246}$ pareceria evidente que Juliano, ao invés de utilem sibi de evictione stipulationem in Titium dari e de evictionem restitui, teria escrito na verdade utilem actionem dari e auctoritatem restitui. Pois o que ficou no texto compilado é um puro sem-sentido. ${ }^{247}$ Tratar-se-ia a ação auctoritatis de uma actio utilis ou porque a auctoritas se extinguia com o término do prazo do usucapião ou porque a coisa dada em mancipatio no caso concreto não o fora de acordo com o direito civil. ${ }^{248}$

Certamente estariam interpoladas, segundo o autor, algumas passagens de Cels. 17 dig. e Papin. 28 quaest., ${ }^{249}$ conforme já indicamos.

Mais significativa é uma passagem de um jurista a que LENEL não faz referência explícita, já examinada por MOMMSEN, que identificamos como sendo Venul. 17 ad stipul., recolhida em Pal. I, fr. 74 (fr. 76 h. t.). Lê-se: «Si alienam rem mihi tradideris et eandem pro derelicto habuero, amitti auctoritatem, id est actionem pro evictione, placet».

Segundo ele, temos quase uma confissão tácita do compilador justinianeu de ter usado, em outras passagens, do mesmo expediente de atualização de que se utilizou aqui: auctoritas, id est actionem pro evictione, substituindo o antigo pelo novo sistema de garantia - muitas vezes abreviando passagens de modo a tornar impossível a reconstrução do pensamento original. ${ }^{250}$

O jurista Paulo deixaria entrever, ainda, em 76 ad. ed., o antigo sistema, ao usar a expressão amissam actionem pro evictione, citando o antigo

\footnotetext{
245 «Si quidem ex besse quem a me acceperas semis petitus fuerit, Titius non tenebitur, si vero triens quem Titius tibi tradiderat et sextans ex besse quem a me acceperas petitus fuerit, Titius quidem pro triente, ego pro sextante evictionem tibi praestabimus».

246 «Minor viginti quinque annis fundum vendidit Titio, eum Titius Seio: minor se in ea venditione circumscriptum dicit et inpetrat cognitionem non tantum adversus Titium, sed etiam adversus Seium: Seius postulabat apud praetorem utilem sibi de evictione stipulationem in Titium dari: ego dandam putabam... nam si ei fundus praetoria cognitione ablatus fuerit, aequum erit per eundem praetorem et evictionem restitui».

${ }^{247}$ Das Edictum Perpetuum cit., p. 544.

248 Idem, p. 545

${ }^{249}$ Pal. I, fr. 234 e 349 respec.

${ }^{250}$ Das Edictum Perpetuum, p. 545).
} 
jurista Sabino; fica evidente para LENEL que originalmente o texto dizia amissam auctoritatem.

Os restantes fragmentos não trazem nada de novo; apenas auxiliam, por darem alguma evidência de que tratavam da mancipatio e de res mancipi. Reforçam, em suma, para o autor, ainda mais a tese de que falam da antiga actio auctoritatis. ${ }^{251}$

Neste momento da história da exegese das supostas fontes da actio auctoritatis, a doutrina se consolidou a ponto de passar definitivamente para os manuais de direito romano. Os seus fundamentos eram talvez suficientemente seguros para que fossem admitidos, até que novos estudos provassem o contrário; o fato é que mesmo os juristas que formularam a chamada teoria "generalista» da auctoritas, até os anos 60, mal se atreveram a questioná-la a fundo.

Além dos fundamentos aduzidos por Mommsen, Huschke, Pernice, GIRARD e LENEL, ${ }^{252}$ - omitimos aqui, por brevidade, um estudo mais amplo de RABEL, Bonfante, ARANGIO-Ruiz, ThORMANn ${ }^{253}$ e outros da mesma linha, que pouco contribuíram para a fundamentação dessa posição - há os estudos mais recentes de KASER e MAYER-MALY, que consolidaram a doutrina alemã sobre a auctoritas rerum com ênfase na regra decenviral do usus-auctoritas.

Tanto um como o outro principiam o seu estudo da auctoritas no contexto da propriedade e do usucapião, e não no da evicção, e têm diante de si duas tendências diversas no estudo da auctoritas rerum até a metade do século XX: a tradição consolidada por MOMMSEN e GIRARD, da auctoritas como «Gewährschaftshaftung von Manzipationsverkäufern», e a interpretação mais recente da auctoritas como «Ausdruck einer Berechtigung», defendida por LEIFER, GIFFARD, LEVY-BRUHL, MAgDELAIN e Roussier, entre outros. ${ }^{254}$

\footnotetext{
${ }^{251}$ Idem, p. 546. P. F. GIRARD, La garantie d'éviction dans la vente consensuelle, in NRH 8 (1884), p. 395, mais tarde, qualificará de «ingénieuse» a tentativa de LENEL.

${ }^{252} \mathrm{~V}$. também a exegese e teoria de DE VISSCHER, exposta no item anterior.

${ }^{253} \mathrm{~V}$. item anterior.

254 Th. MAYER-MALY, Studien zur Frühgeschichte der usucapio // cit., p. 235. A peculiaridade das posições de MAYER-MALY e KASER é que, apesar de se inserirem na tradição "garantista», cujo núcleo é a investigação da garantia decorrente da mancipatio, partem do estudo da propriedade e do usucapião - ponto de partida comum a alguns autores que CASINOS-MORA denomina "generalistas» (La noción romana de auctoritas y la responsabilidad por auctoritas cit., p. 84), talvez por influência de
} 
MAYER-MALY revisita as fontes com a finalidade de descobrir qual a função mais antiga da regra do usus-auctoritas das XII tábuas ${ }^{255}$ e observar o seu desenvolvimento histórico.

Há um primeiro grupo de fontes que fundamenta a sua interpretação da regra decemviral, cujos únicos elementos originais seriam usus, auctoritas, fundus e biennium: Cic. top. 4, 23; Cic. pro Caec. 19, 54; Gai. 2, 42; 2, 54; e 2, 204, além do comentário de Boécio a Cic. Top. 4, 23. O autor a expressar o significado mais original seria Cícero pois, após um momento intermediário em Gaio, usus auctoritas passa a significar invariavelmente usucapio.

Apoaindo-se em Cícero, conclui que a regra estava relacionada ao fator temporal e a determinados objetos suscetíveis de domínio (bestimmten Objekten der Rechtsherrschaft). ${ }^{256} \mathrm{~A}$ interpretação mais natural, entretanto, tendo em conta o que a regra do usus-auctoritas tem em comum com a da aeterna auctoritas, deveria excluir a possibilidade de que a norma estivesse relacionada apenas à segunda função (limitar os sujeitos de direito a um objeto de domínio). ${ }^{257}$

Um segundo grupo de fontes - já citadas - permite um novo passo. Trata-se de Cic. pro Mur. 12, 26 e pro Caec. 19, 54, que mencionam uma actio in

P. NoAilles. Essa divisão das posições em dois grupos antagônicos, apesar de simplista, auxilia o pesquisador a entender a radical diferença entre esses autores. Fica clara a orientação privatística do primeiro grupo, que inclui KASER e MAYER-MALY, e a orientação publicística do segundo, mesmo em se tratando de instituições de direito privado, como o usucapião; citamos como exemplo a teoria de LEIFER, que caracteriza a auctoritas como "Sippengewährschaft», uma garantia coletiva em favor do adquirente que perdeu a posse da coisa para um estrangeiro ou sofreu furto (Altrömische Studien IV Mancipium und auctoritas, in SZ 57 (1937), pp. 131-133).

${ }^{255}$ As funções seriam três, segundo KASER, cuja doutrina é ponto de partida para MAYER-MALY: a) uma regra de prescrição (Verschweigungsregel) a conferir ao adquirente de uma res mancipi, após o término do prazo da auctoritas, uma melhor posição do ponto de vista processual-probatório; b) uma atribuição de propriedade absoluta ao adquirente, após o término do prazo; c) limitação temporal da garantia (contra evicção) por parte do alienante, com a finalidade de proteger a posse tranqüila do adquirente.

${ }^{256}$ Studien zur Frühgeschichte der usucapio I/ cit., p. 238. O ponto em comum com o adágio da lex Atinia é apenas o fator temporal: nas XII tábuas menciona-se o prazo de dois anos e, naquela, um prazo indeterminado (aeterna auctoritas adversus hostem).

${ }^{257} \mathrm{O}$ argumento de MAYER-MALY é bastante sutil. Segundo ele, uma interpretação segundo a qual a função da regra do usus auctoritas fosse tão somente limitar a possibilidade de apropriação (auctoritas) a determinados objetos de domínio (i. e., aos fundi) não estaria levando em conta a norma da lex Atinia (conservada por Cic. de off. 1, 12, 37), que não traz nenhuma limitação do ponto de vista do objeto de domínio. Isso, como é evidente, enfraquece a posição «generalista» (v. nota acima). 
auctorem praesentem e a frase quando in iure te conspicio, etc., também registrada mais tarde por Valério Probo.

Mas a fim de relacionar tudo isso com a garantia pela evicção, é necessário, segundo o autor, recorrer a Plauto, ${ }^{258}$ que para ele representa o «Privatrechtsverkehr» da época. ${ }^{259}$ A exegese de MAYER-MALY requer, entretanto, penetrar no contexto das comédias, especialmente Curculio, Poenulus e Trinummus.

Dentre essas fontes plautinas, as mais relevantes são certamente Poen. 1, 1, 145 e ss.; Curc. 4, 2, 490 e ss.; e Trin. 1, 2, 217 e ss.

O autor conclui, a partir do primeiro texto, que auctor e auctoritas estão ligados um ao outro de modo essencial - auctoritas é uma propriedade de auctor, tal como concluíra HEINZE; ${ }^{260}$ e que o auctor não exerce um direito, mas sim origina uma garantia ou direito subjetivo («erscheint als Urheber einer Berechtigung»). E assim estaria confirmada a interpretação da auctoritas como garantia. ${ }^{261}$

Do segundo texto, o autor extrai que a mancipatio é o fundamento da auctoritas, especialmente da seguinte seqüência de expressões: et mancupio tibi dabo - mancupio accipiam - nec vobis auctor ullus nec vosmet estis ulli. Do terceiro, por fim, que a auctoritas formava uma cadeia de proprietários-garantidores (Vormänner), que garantiam suscessivamente a legitimidade das alienações: quod si exquiratur usque ab stirpe auctoritas, etc.

O último grupo de fontes compreende Cic. de harusp. 7, 14; Sen. controv. 7, 6, 22, ${ }^{262}$ e CIL III 1998 e VI 8439.

A primeira destas fontes é muito utilizada pelos corifeus da exegese «generalista», a exemplo de LEVY-BRUHL, MAGDELAIN e RoussieR; ${ }^{263}$ mas para

258 Embora obedeça a uma ordem diversa, a argumentação de MAYER-MALY, malgrado mais sofisticada, funda-se nas mesmas fontes às quais recorreram MOMMSEN e GIRARD, como confessa adiante, ao declarar a sua filiação às suas conclusões (Studien zur Frühgeschichte der usucapio I/ cit., p. 243: «Es entspricht vielmehr in wesentlichen Zügen den Erkenntnissen von Mommsen und Girard»).

${ }^{259}$ Idem, ibidem.

${ }^{260}$ Auctoritas cit., p. 349.

261 Studien zur Frühgeschichte der usucapio // cit., p. 241. Para MAYER-MALY, o alienante é auctor muito antes de aceitar o dever de assistência processual; daí o presente fuas na pergunta conservada por Cícero e Valério Probo, segundo ele a traduzir-se como «Bist du der auctor?» (idem, p. 245).

262 «Ex tabellis emptionis multi sententiam trahere temptaverunt. Albucius dixit: profer mihi tabellas. Quid hoc est? Generum socer mancipio accepit. Triarius dixit: 'fugitivum, erronem non esse': ita si malum auctorem habemus, gener noster fugitivus est? Blandus dixit: relegamus auctoritatis tabellas: 'furtis noxaque solutum'. Haec generi nostri laudatio est». 
MAYER-MALY, a expressão ius auctoritatis, embora não possa facilmente encaixar-se à noção de garantia, não representa uma função especial na vida jurídica, aparecendo no texto apenas como exemplo da retórica ciceroniana. ${ }^{264}$

De acordo com a passagem de Sêneca e as inscrições citadas, sendo as tabellae auctoritatis documentos de registro de mancipationes e auctor o mancipio dans, a auctoritas teria como conteúdo típicos casos de garantia. ${ }^{265}$

Após expor e analisar, sem maiores novidades, a conhecida passagem de Paulo nas Sententia - cujo sentido não discreparia do da ordem jurídica romana arcaica -, MAYER-MALY retorna à regra do usus-auctoritas para concluir: o sentido original da norma aponta apenas para a limitação temporal da garantia, «Gewährschaftsbefristung»; a sua relação com a prescrição e o efeito aquisitivo só surgiu mais tarde. ${ }^{266}$

A opinião de KASER não diverge essencialmente da sua; entretanto, acrescenta à função primária da norma - limitação temporal da garantia - justamente aquela que MAYER-MALY havia interpretado como sendo uma função tardia, pósdecenviral: a prescrição ${ }^{267}$ e a posse (Verschweigung und Ersitzung).

Com efeito, KASER ${ }^{268}$ argumenta que seria insustentável que as XII tábuas tivessem limitado temporalmente o usus-auctoritas (i) sem impedir o terceiro reivindicante de tomar a coisa e, ao mesmo tempo, (ii) sem assegurar o domínio do mancipio accipiens sobre ela. Em resumo, esses dois efeitos estariam implícitos na limitação temporal da garantia já no período decenviral, quiçá até anteriormente. ${ }^{269}$

\footnotetext{
${ }^{263} \mathrm{~A}$ análise crítica da posição desses autores virá em um capítulo à parte, adiante.

${ }^{264}$ Idem, p. 248.

${ }^{265} \mathrm{~V}$. também a semelhança entre instrumentum auctoritatis e instrumentum emptionis em Scaevol. 5 dig., D. 13, 7, 43 pr.: «Locum purum pignori creditori obligavit eique instrumentum emptionis tradidit: et cum eum locum inaedificare vellet, mota sibi controversia a vicino de latitudine, quod alias probare non poterat, petit a creditore, ut instrumentum a se traditum auctoritatis exhiberet: quo non exhibente minorem locum aedificavit atque ita damnum passus est».

${ }^{266}$ Idem, p. 255.

${ }^{267}$ No sentido do não-uso, «Nichtausübung», que levaria à perda do direito - um efeito negativo da norma do usus-auctoritas.

${ }^{268}$ Altrömisches Eigentum und 'usucapio' cit., p. 122-164. O autor tem em vista uma reformulação e uma unificação do conceito arcaico de propriedade, que inclui institutos como a mancipatio, a in iure cessio, a vindicatio e a norma do usus-auctoritas, bem como o estudo do desenvolvimento da usucapio.

${ }^{269}$ Idem, p. 129-130.
} 
Exposta a exegese dos autores mais representativos da posição "garantista», incumbe-nos pôr à prova os fundamentos dessa tese, oferecendo uma alternativa mais de acordo com o testemunho de Cícero e Gaio, que viam na regra do usus-auctorias uma norma tradicional sobre o usucapião de imóveis. Faremo-lo num capítulo à parte, não sem antes analisar algumas teses contrárias.

\subsection{Críticas e alternativas à teoria tradicional da}

\section{auctoritas como garantia}

Como vimos, a interpretação tradicional da regra das XII tábuas sobre a auctoritas - com exceção da de Cujácio - consistia em descrevê-la como uma posição jurídica de poder, domínio ou posse, associando-a diretamente ao usucapião. Essa idéia é inquestionável já em Gaio e é repetida pelos humanistas, especialmente por Budé e Alciat.

No final do século XIX, essa visão foi substituída pela teoria «garantista» que acabamos de expôr em detalhe. Tendo-se tornado a opinião dominante, foi adotada indiscriminadamente pelos manuais de direito romano. Todavia, dos anos 30 do século $X X$ até os nossos dias, a teoria "garantista» vem sendo combatida por muitos autores que, apesar de sustentarem teorias parcialmente divergentes entre si, têm em comum o núcleo da exegese humanista.

Comentaremos, eventualmente submetendo-os à crítica, ${ }^{270}$ os autores mais importantes nesse contexto: H. LÉVy-BRuhl, A.-E. Giffard, A. MAgdelain, R. YARON, F. LeIfer, D. Pugsley e G. DiósDi. Apresentaremos também, brevemente, a recente reformulação do assunto por CASINOS MORA, que se apoiou em duas contribuições - a de F. LeIFER, nos anos 50, e a de P. FUENTESECA, mais recentemente - que julgamos essenciais, com alguns reparos, para sustentar a relativamente nova compreensão do assunto que apresentaremos no capítulo seguinte.

$\overline{{ }^{270} \text { A nossa crítica à teoria «garantista» virá especialmente no capítulo } 3 .}$ 
Um bom ponto de partida é a peculiar tese de LÉVY-BRUHL, ${ }^{271}$ mais tarde sustentada, com mais argumentos, por R. YARON. O autor pretendeu formular uma noção totalmente nova da auctoritas das XII tábuas e da lex Atinia, embora tributária dos humanistas, que associavam a auctoritas à propriedade. Segundo ele, essa concepção humanista serve para a lex Atinia e para aquela disposição referente ao hostis, mas não para a regra usus auctoritas fundi biennium est. ${ }^{272}$

Ele parte do princípio de que o termo auctoritas tem um mesmo sentido nessas três disposições. Para isso, observando que a lex Atinia protege a pessoa que teve o seu bem furtado, e que a disposição semelhante sobre a aeterna auctoritas protege o cidadão romano desapossado, é necessário que a regra do usus auctoritas... também diga respeito a alguém que, embora seja proprietário, tenha perdido a posse. ${ }^{273}$

A auctoritas, nesses três fragmentos, deveria ter o sentido de poder de direito ${ }^{274}$ pertencente ao proprietário que perdeu a posse do bem; assim, a regra das XII tábuas significaria que "o regime do usus e da auctoritas dura 2 anos», de modo que o usus se refira ao poder de fato do possuidor e a auctoritas ao «droit théorique appartenant au propriétaire», uma espécie de nua-propriedade. ${ }^{275}$

Sua crítica se dirige justamente à teoria de que a auctoritas decenviral nada mais é do que a garantia do mancipio dans pela transferência efetiva da coisa. ${ }^{276}$ A sua objeção é importante: se a mancipatio é um modo solene, quase público, de transferência da coisa mancipi, incluindo uma declaração do adquirente de que ela é sua pelo direito dos Quirites, não seria necessário recorrer ao usus de dois anos para que essa propriedade se confirmasse com a auctoritas.

\footnotetext{
271 «Auctoritas» et usucapion cit., pp. 14-30.

272 Idem, p. 15.

273 Idem, pp. 25-26.

274 Para chegar até essa conclusão, LÉVY-BRUHL recorre à analogia com a auctoritas tutoris, a auctoritas populi, a auctoritas patrum, etc., que expressam um poder de direito (idem, p. 20-22).

${ }^{275}$ Idem, p. 26. Isso está de acordo com a sua proposta de interpretação de Cic. de Harusp. 7: «...sed tamen jure privato, jure hereditario, jure auctoritatis, jure mancipii, jure nexi...». Enquanto jure mancipii faria referência aos edifícios adquiridos por mancipatio simples e o jure nexi àqueles adquiridos por mancipatio fiduciária (um ato per aes et libram), o jure auctoritatis seria o das servidões prediais ou de nua-propriedade.

${ }^{276} \mathrm{O}$ autor tem em vista especialmente a formulação de M. PERNICE, Labeo cit., p. 115, que já examinamos neste capítulo, no item 2.2.
} 
Nem haveria necessidade, em caso de evicção, do adquirente recorrer ao vendedor: bastava - o que é verossímil - recorrer ao ato de transferência: a mancipatio, a in jure cessio, o título hereditário. Caso não fosse suficiente, recorreria às testemunhas do negócio libral. A auctoritas do vendedor só seria necessária, supõe LÉVY-BRUHL, quando, em razão de um elevado número de transferências de domínio, o adquirente não lograsse provar o ato de transferência; mas isso só ocorreria raramente na Roma arcaica, "composta de um pequeno número de famílias", o que tornaria sem sentido prático o adágio decenviral. ${ }^{277}$

A.-E. GIFFARD havia criticado M. F. DE VISSCHER, cuja tese já expusemos, em termos semelhantes, examinando as três disposições citadas. ${ }^{278}$

Ele também concebe a auctoritas como uma «autoridade de direito» em oposição a um mero poder de fato - sobre a coisa, sentido este presente nas três disposições, rejeitando a tese da auctoritas como garantia do mancipio dans e desvinculando-a, portanto, da mancipatio. ${ }^{279}$ Perfazendo-se o usucapião, essa autoridade de direito faz do possuidor um proprietário. ${ }^{280}$

É comum aos críticos da teoria da auctoritas como garantia do mancipio dans sequer examinar outras fontes; o exame se restringe a estes três fragmentos. Para GIFFARD, são estas as fontes principais - são essas, aliás, as que examinaremos e traduziremos mais adiante -, e elas se reportam tão-somente ao usucapião, e não têm nada em comum com a mancipatio; bastaria, para prová-lo, o argumento de LÉVY-BRUHL de que a mancipatio, sendo solene e constituindo um modo de transmissão da propriedade quiritária, dispensa a necessidade de usucapião. $^{281}$

GIFFARD explica ainda que a cópula usus et auctoritas teria servido para exprimir a noção de usucapião em razão de não haver, ainda, a idéia de dominium, pois ius tinha apenas um sentido objetivo. Gaio teria rejeitado a expressão usus

\footnotetext{
277 «Auctoritas» et usucapion cit., p. 16-18. Esse argumento, de autoria de GIFFARD, é certamente a fonte da objeção mais aprofundada de CASINOS-MORA, cuja fragilidade provamos no item 1.1.

${ }^{278}$ Le sens du mot "auctoritas» dans les lois relatives a l'usucapion, in RH 17 (1938), pp. 339-364. Nesse artigo, ele precisa e explica o que escrevera em Revue des Études Latines (1937), p. 25.

${ }^{279}$ Idem, p. 353.

${ }^{280}$ Idem, p. 362.

281 «Auctoritas» et usucapion cit., p. 16.
} 
auctoritas como um arcaísmo, consagrando o usucapião. ${ }^{282}$ Retomaremos essa idéia ao realizar a exegese dessas três fontes.

R. YARON sustentou também tese semelhante à de LÉVY-BRUHL. Seguindo MAYER-MALY, decidiu por limitar radicalmente as fontes da sua pesquisa, indo mais longe que aquele, a ponto de excluir as fontes literárias (Plauto e Terêncio) e a fórmula in praesentem auctorem, fixando-se, como GIFFARD e LÉVY-BRUHL, nas três provisões mais diretamente ligadas à auctoritas na sua busca por um sentido comum.

Uma sua contribuição importante foi ter percebido que o instituto do usucapião foi um dos que mais se alteram com o passar do tempo, e que algumas das suas características originais teriam provavelmente se perdido e estariam ausentes das fontes clássicas e tardias. ${ }^{283}$

O cerne da exegese de YARON - criticando simultaneamente MAYERMALY, KASER e DE VISSCHER - está no seguinte: a auctoritas, nessas fontes, beneficia aquele que alega ser (the claimant), contra o possuidor (holder), o verdadeiro dono do objeto. No caso da disposição das XII tábuas (VI, 3), a possibilidade de fazer tal alegação está limitada a dois anos; nos dois demais casos, não há limitação. ${ }^{284}$

Quanto à regra do usus auctoritas... (trata-se, segundo ele, de um assíndeto, mas dentro do qual cada termo aponta para uma situação ainda não resolvida), usus se refere àquele que detém e utiliza o objeto, e auctoritas a outra pessoa que, opondo-se a ela, apoia-se numa relação com o objeto que é prior tempore com relação ao presente usus e, conseqüentemente, potior jure; para que o detentor adquira uma posição inatacável, ele deve se manter na posse por mais de dois anos. Quando esse período se completar, a auctoritas, que dá a possibilidade de recuperar o objeto, não mais existirá.

\footnotetext{
${ }^{282}$ Idem, p. 363.

${ }^{283}$ Reflections on usucapio, in TR 192 (1967), p. 191. Desenvolvemos esse argumento adiante, no capítulo 3.

${ }^{284} \mathrm{O}$ autor cumpriu os requisitos do que, segundo ele - com o que concordamos -, deveria ser uma interpretação adequada de uma lei antiga: «to be acceptable, an interpretation must be simple, straightforward. For all our difficulties in understanding them, early laws are precise and concise, are not guilty of verbiage, do not say one thing while meaning another, and dispense with circumlocution», de modo que, quanto mais tortuosa uma interpretação, mais suspeita será (idem, p. 197). Nisso vai uma forte crítica a M. KASER.
} 
Já quanto às outras duas regras, sendo a auctoritas aeterna, não há a possibilidade de um usus legalmente válido. Adversus hostem... significa que, contra um estrangeiro, a auctoritas pode ser utilizada sem limitação de tempo; um objeto nas mãos de um estrangeiro pode ser sempre recuperado (usucapião vedado ao estrangeiro). ${ }^{285}$ Quod subruptum... significa que uma res furtiva sempre pode ser recuperada das mãos do ladrão. ${ }^{286}$ Como diremos na nossa exegese dessa regra, a auctoritas se refere ao requerente-proprietário, e a negação da usucapio dirige-se ao ladrão ou estrangeiro.

Pensamos que essa interpretação - mais aprimorada que a de LÉVYBRUHL - é, com alguns reparos, bastante adequada para o direito da época de Cícero e Gaio, especialmente por ser dotada de raro sentido prático. Quanto à regra do usus auctoritas..., certamente lhe faltará, como o próprio YARON indiretamente reconhece, ${ }^{287}$ alguns elementos da vigência decenviral (séc. $V$ a.C.) desse preceito. $^{288}$

Semelhante é a interpretação de D. PugsLEY. Para ele, usus auctoritas é um assíndeto que se refere a duas realidades distintas mas paralelas, e que operam harmoniosamente («balance each other»). ${ }^{289}$ A objeção, nesse sentido, que

\footnotetext{
${ }^{285}$ Todavia, essa interpretação - «usucapião vedado ao estrangeiro» - nos parece uma redundância, dado que o usucapião sempre foi, como atesta Gaio, jus proprium civium romanorum (Gai. 2, 65). ${ }^{286}$ Idem, pp. 203-204.

287 «...in the sources available to us (in the main classical and late) some early distintinctions will have been lost altogether, or at least blurred» (idem, p. 191).

${ }^{288}$ Tentaremos fornecer uma hipótese sobre essa vigência decenviral no capítulo 5. O que lança suspeitas sobre essa interpretação demasiado clássica é a ausência de uma referência ao elemento augural do direito decenviral; certamente o seu funcionamento era semelhante, mas dotado de algumas particularidades próprias do direito arcaico.

${ }^{289}$ The Roman Law of Property and Obligations, Cape Town, Juta \& Company, 1972, p. 40. Em outra passagem, o autor discute a teoria garantista, negando o papel tradicional atribuído à actio auctoritatis: para ele, essa ação não era de titularidade do comprador, tendo como objetivo buscar uma compensação em caso de evicção - o que feriria o princípio da simplicidade dos atos jurídicos formulado por JHERING, idéia que já expomos no capítulo anterior -, mas sim uma ação em favor do proprietário original da coisa, que teria sido vendida por outro, não-proprietário, a um terceiro. $\mathrm{O}$ caso é que, na polêmica teoria de PUGSLEY, a mancipatio, em razão da sua publicidade, permite que o comprador adquira um bom título mesmo se o vendedor não é o proprietário, mesmo se ele próprio furtou a coisa. Assim, o dono, cuja coisa foi perdida ou furtada e em seguida transferida via mancipatio por outro a um terceiro, perde a propriedade, mas pode ajuizar uma condictio ou uma actio furti contra aquele que a transferiu ao terceiro (o dono original não pode mais mover uma vindicatio, pois perdeu a propriedade no momento em que a sua coisa foi transferida a outro por um non dominus através mancipatio). Aqui entra a estranha teoria do autor: já que a legis actio per condictionem só foi criada provavelmente no séc. III a.C., a ação do antigo dono contra aquele que vendeu a sua coisa por
} 
faz à teoria da garantia é que o uso de uma res e uma relacionada garantia contra evicção não são conceitos paralelos e harmoniosos. ${ }^{290}$

Usus é o antigo nome da possessio e, por ser seu antecedente, representa substancialmente o mesmo conceito. ${ }^{291}$ Mas o emprego de usus era especialmente justificado por, diversamente da possessio - que permite significar uma mera 'posse' sem uso prático da coisa -, implicar o uso efetivo de escravos e certos animais, res mancipi. Entretanto, não seria necessário, para que se desse usus, que a coisa fosse efetivamente usada; bastava que estivesse à disposição do proprietário.

O adágio trata do caso de uma coisa mancipi que veio às mãos de alguém informalmente, por traditio; do contrário, tratar-se-ia de manus: manumcipium, ou seja, mancipium. (Por isso o nome tardio da aquisição da coisa pelo usus é usucapio, em oposição a mancipatio).

O autor precisa, seguindo o mesmo caminho de LEVY-BRUHL e outros, que usus não implica propriedade; pelo contrário. O antigo nome e conceito para essa relação jurídica entre o dono e a coisa é justamente auctoritas - que existe quando não se tem usus sobre ela. Entretanto, estes são, nas palavras do autor, apenas dois lados da mesma moeda. ${ }^{292}$

O caso do usus-auctorias aplica-se, assim, segundo PUGSLEY, a quem vendeu uma res mancipi através de mera traditio. Durante um ou dois anos, o vendedor tem auctoritas, ou seja, permanece sendo proprietário; o comprador tem mero usus, sem qualquer proteção legal. Ao final do prazo, o comprador finalmente será o proprietário ex jure Quiritium, substituindo o vendedor na cadeia do domínio.

Quanto ao adágio adversus hostem..., a idéia é que, se um estrangeiro mantivesse consigo uma res, o cidadão romano sempre a poderia recuperá-la

mancipatio a outro era, antes da introdução da condictio, a chamada actio auctoritatis (pp. 7-17, para mais detalhes). Cf. também D. PUGSLEY, Quod autem valet mancipatio..., in Americans are aliens and other essays on Roman Law, Exeter, University of Exeter, 1989, pp. 32-40).

${ }^{290}$ Idem, p. 40.

291 A mesma idéia aparece em M. KASER, Eigentum und Besitz im älteren römischen Recht, Weimar, H. Böhlaus, 1943, p. 325: «bei der possessio im alten Sinne... bringt die teilweise Verschmelzung mit dem usus-Besitz die völlige Anerkennung als Einrichtung des Privatrechts mit sich». V. outra passagem sobre o assunto às pp. 87-88.

${ }^{292}$ Idem, p. 42. 
através de uma legis actio sacramento in rem. ${ }^{293}$ Quanto à res furtiva, o cidadão romano sempre poderia recuperar a coisa das mãos do ladrão, sem limitação de tempo (o mesmo quanto ao recurso à actio auctoritatis segundo a teoria do autor). ${ }^{294}$

Ao contrário das considerações de G. DıósDı, que pouco trazem além de ceticismo, ${ }^{295}$ os estudos de F. LEIFER e A. MAGDELAIN trazem um novo elemento à discussão: a auctoritas como garantia coletiva dos Quirites em favor do verdadeiro proprietário. $^{296}$

O funcionamento dessas três disposições, para MAGDELAIN, está em parte de acordo com o que vínhamos descrevendo. Para ele, entretanto, a auctoritas é equiparada à idéia de título. ${ }^{297}$

Mais exatamente, a auctoritas rerum é - no primeiro artigo do autor sobre o assunto - o título de propriedade criado por um ato de aquisição, e que apenas supõe um auctor do qual o adquirente recebe a coisa. Mas esse auctor não

${ }^{293}$ E seguindo o raciocício do autor com respeito à actio auctoritatis, o preceito significa também que, se o estrangeiro vier a transferir a coisa através de mancipatio, o cidadão romano sempre poderá acioná-lo auctoritatis. $\mathrm{O}$ fato do estrangeiro não ser legalmente capaz, argumenta o autor, não impede que ele tome parte numa mancipatio, de facto (idem, p. 44).

${ }^{294}$ Idem, p. 45.

295 Ownership in Ancient and Preclassical Roman Law, Budapest, Akadémiai Kaidó, 1970, p. 89. O autor, após analisar de forma quase exaustiva o imenso material que se produziu sobre o usus auctoritas, julga que a melhor saída é uma suspensão do juízo. Nas suas considerações, entretanto, o autor procura falar da auctoritas - segundo ele, um conceito que dificilmente poderia ser descrito com a linguagem atual - sem referir-se ao seu conteúdo. A sua conclusão é que as palavras usus e auctoritas, juntas, significam que aquele que usou a coisa obtém uma posição legal inquestionável opinião que o coloca na mesma linha de LÉVY-BRUHL e outros (v. pp. 75-81, para uma forte crítica da teoria da auctoritas-garantia). Acrescenta o autor que a idéia decenviral do usus auctoritas seria uma solução prática, sem causa especulativa, com a finalidade de livrar o possuidor, após o prazo legal, do peso de provar a sua posição jurídica. Daí a característica de «indisputabilidade» da auctoritas como posição (pp. 89-90).

${ }^{296}$ Adiantamos que a consciência dessa referência da auctoritas ao corpo dos Quirites diminuiu com o tempo; ela já não é considerada como algo vivo, em parte, pelos romanos do tempo de Gaio, embora ainda apareça nos discursos de Cícero (como veremos, Gaio substituirá definitivamente a expressão usus auctoritas por usucapio, como conseqüência dessa "perda de referência»).

${ }^{297}$ Auctoritas rerum, in Mélanges F. de Visscher IV, RIDA (1950), p. 139. A mesma idéia aparece em A. WATSON, Mancipatio and Transfer of Ownership, in Rome of the XII Tables - Persons and Property, New Jersey, Princeton University, 1975, p. 143: «auctoritas is the right or title of ownership». Ele ainda especifica que, se o significado mais adequado de auctor é 'predecessor', então auctoritas seria melhor descrita como "o título deste predecessor» (idem, ibidem). V. também A. WATSON, The Law of Property in the Later Roman Republic, London, Clarendon, 1968, pp. 21-23. Mas WATSON parece referir-se a um título meramente privado, e não público, como na teoria de MAGDELAIN. 
existe: trata-se de uma ficção legal criada pelos decênviros. ${ }^{298} \mathrm{~A}$ auctoritas nasce do usus prolongado, e é assimilada a um título («usus de dois anos equivale a título»); ${ }^{299}$ é uma auctoritas sem auctor, ${ }^{300}$ como na teoria de LÉVY-BRUHL e, mais tarde, na de F. J. CASINOS-MORA.

Do mesmo modo, não faz sentido, na outra regra decenviral, falar-se em uma "garantia eterna». A aeterna auctoritas é um título que pertence ao cidadão romano, válido contra o estrangeiro no procedimento status dies cum hoste mencionado por Fest. 314. Sendo eterno, significa imprescritibilidade: o hostis está impedido de usucapir uma coisa pertencente a um romano. ${ }^{301}$

Por fim, na lex Atinia, o título (auctoritas) se aplica ao que foi furtado: como ele é eterno, o efeito é a imprescritibilidade das coisas furtadas, tal como no caso do estrangeiro, ou seja, a proibição de usucapião dirigida ao ladrão (interpretação conforme à de Lab. 5 pith., D. 41, 3, 49 pr.). Mas o que teve a coisa furtada pode se beneficiar do usus auctoritas, desde que a recupere. ${ }^{302}$

Mas qual o fundamento da auctoritas rerum? MAGDELAIN responde a essa pergunta num escrito posterior. ${ }^{303}$ Enquanto está apenas na posse da coisa, antes de completar-se o usucapião, o adquirente beneficia-se da auctoritas privada daquele que the transmitiu o bem («propriedade relativa» fundada no auctor). Quando o prazo legal se completa, ele passa a fundar-se na auctoritas coletiva, a testemunha dos Quirites; a partir desse momento, entra em jogo a cláusula ex jure Quiritium («propriedade absoluta», na visão do autor), que pode ser invocada numa reivindicação e tem valor de presunção absoluta em favor daquele que tem usucapião.

O fundamento, portanto, da auctoritas rerum nessas três disposições seria o corpo cívico formado pelos Quirites, e não o auctor privado que transmitiu a

\footnotetext{
298 P. Vocl, Modo di acquisto della proprietà - corso di diritto romano, Milano, Giuffrè, 1952, p. 51, observa que um título fictício é uma coisa "un poco inconsueta». Tal tese demandaria mais argumentos, e isso está ausente em MAGDELAIN.

${ }^{299}$ Idem, p. 141.

${ }^{300}$ Seu fundamento está no próprio direito civil, conforme a passagem de Cic. pro Caec. 26, 74: ab jure civili sumitur.

${ }_{301}$ Idem, p. 145-146.

302 Idem, p. 147-152.

${ }^{303}$ L'acte per aes et libram et l'auctoritas, in RIDA 28 (1981), pp. 125-161.
} 
coisa. No seu escrito mais recente sobre o conceito de ius no direito antigo, MAGDELAIN diz que a cláusula ex jure Quiritium tem como objetivo definir direitos absolutos, colocando-os sob a proteção e a garantia do corpo cívico. No caso do usus auctoritas, a propriedade absoluta - adquirida à vista de todos através da posse duradoura de um ou dois anos - é estabelecidade pelo testemunho dos cidadãos. Assim, a cláusula pode ser usada no processo in rem para prova da propriedade; basta o testemunho de um cidadão que, respondendo ao postulo anne fias auctor, afirma: auctor fio. ${ }^{304}$

A auctoritas é, portanto, «la garantie du corps civique de la propriété absolue qui en résulte», que é acrescentada ao usus após o prazo de um ou dois anos. $^{305}$

Essa mesma idéia sustentou F. LEIFER, um dos poucos autores alemães a divergir da teoria da auctoritas como mera garantia do mancipio dans. O seu método foi prescindir totalmente da sua «educação romanística», bem como das construções dos juristas, e reexaminar os dois conceitos-chave presentes na regra das XII tábuas: usus e auctoritas. ${ }^{306}$ Essa sua singular preocupação com uma caracterização adequada do direito arcaico coloca-o entre os autores mais importantes que trataram do tema. ${ }^{307}$

\footnotetext{
${ }^{304}$ De la royauté et du droit de Romulus a Sabinus, Rome, L'Erma di Bretschneider, 1995, pp. 82-83. Nesta obra mais recente, MAGDELAIN não menciona a idéia de um auctor privado - papel a ser exercido pelo transmitente - criado por ficção legal: ele menciona apenas o testemunho de um ou mais cidadãos que representariam todo o corpo cívico, de modo que a auctoritas teria sempre um sentido público. Não se trata, portanto, na opinião tardia de MAGDELAIN, de uma «auctoritas sem auctor» (como veremos, essa é a concepção de CASINOS-MORA), mas de uma auctoritas coletiva que pode ser tornada eficaz por qualquer cidadão romano. Essa garantia é invocada no processo in rem movido contra aquele que adquiriu a coisa pelo usucapião através da «fórmula dos Quirites».

${ }^{305}$ Idem, p. 84.

${ }^{306}$ Mancipium und auctoritas... cit., p. 131. Não nos parece que o autor tenha sido cuidadoso a esse respeito, pois - como é, em certa medida, inevitável - o seu esboço faz uso constante da terminologia moderna.

${ }^{307} \mathrm{O}$ autor foi o primeiro a dizer, claramente, que os juristas clássicos tinham mantinham uma interpretação anacrônica da regra expressa nas XII tábuas; e que apesar disso, referindo-se aos romanistas, «man immer wieder mit den von der klassischen Jurisprudenz erarbeiteten Denkfiguren an die Worte der Dezemvirn herangetreten ist» (Mancipium und auctoritas, in SZ 57 (1937), p. 124). Esse ponto de partida, quase sempre ignorado pelos romanistas, será adotado nos capítulos 4 e 5 . A desconsideração dessa «interpretação clássica» (usus auctoritas = usucapião), entretanto, nos parece menos grave que a sua adoção como perfeitamente representativa da vigência arcaica da auctoritas rerum, como o fizeram os humanistas e alguns autores modernos.
} 
Para ele, uma garantia tipicamente tribal (Samtwährschaft ou Sippengewährschaft) dada pela coletividade seria o antecedente arcaico do direito subjetivo. No período decenviral não teria existido a propriedade privada no sentido individualista, mas simplesmente um reconhecimento coletivo de situações de poder fático sobre as coisas.

O usus decenviral seria, de acordo com as conclusões de LEIFER, um termo análogo ao Gewere do direito germânico: ${ }^{308}$ uma posição de domínio com aparência de direito, ${ }^{309}$ mas de manifestação essencialmente fática, e que, sendo visível, crescia dia após dia. ${ }^{310}$

Já a auctoritas adquire, naquele contexto familiar-tribal, o papel de reforço, de confirmação dos atos jurídicos dos representantes da tribo (paterfamilias) no que se refere ao intercâmbio de bens, de modo a prover o adquirente de apoio suficiente contra pretensões do próprio alienante $\mathrm{e}$ de terceiros (Sippendefensionspficht). Mais tecnicamente, ela seria uma posição que permite ao adquirente recorrer à garantia da coletividade - especialmente, em contraposição ao usus, quando se perdeu o poder fático sobre a coisa. ${ }^{311}$

A auctoritas, portanto, também para LEIFER, não remete ao transmissor, ao auctor das teorias garantistas, mas à coletividade. ${ }^{312}$

P. FuenteseCA, por outro lado, aduz que é impossível que haja uma auctoritas sem auctor: em casos análogos isso não acontece, como no do tutor e no dos senatores. O auctor seria um prius sem o qual não pode haver auctoritas.

Para ele, a auctoritas é um "princípio legitimador» com origem no direito augural, ou seja, um elemento de natureza pública. ${ }^{313} \mathrm{~A}$ norma decenviral, diz ele, ratifica a aquisição da auctoritas mediante o usus bienal dos fundi.

\footnotetext{
${ }^{308}$ No mesmo sentido, M. KASER, Eigentum und Besitz... cit., p. 87.

${ }^{309}$ Isso significa, em princípio, na teoria de Otto von Gierke sobre o Gewere, que o exercício do poder de domínio (Machtausübung) equivalha a um exercício do direito de domínio (Rechtsausübung).

${ }^{310}$ Mancipium und auctoritas... cit., p. 135. Nessa época parecia indiferente a presença ou não de algo como o animus domini, e nem se podia pensar numa possessio ad interdictum.

311 Idem, pp. 136-138.

${ }^{312}$ Poder-se-ia especular, entretanto, que o paterfamilias, ao transmitir o bem, tornava-se, em nome da tribo, responsável pela sua conservação em mãos do adquirente; e a ele, por esse motivo, é que se daria o nome de auctor. Dizê-lo, contudo, é discordar do modo como LEIFER expôs esse assunto.

313 Trasferimento della proprietà e "auctoritas» nella vendita romana, in L. VACCA (org.), Vendita e trasferimento della proprietà nella prospettiva storico-comparatistica - Atti del Congresso
} 
Esse princípio faz daquele que usa o fundus pelo tempo previsto nas XII tábuas dominus ex iure Quiritium. Como em PugsLeY, trata-se apenas do caso de res mancipi transmitida por mera tradição.

O bem adquirido entra, antes do término desse prazo, na esfera jurídica do comprador - já que estamos diante de um usus emptionis causa - apenas in bonis, fundado numa iusta causa possidendi. Já o vendedor permanece, durante o biênio, titular quiritário (nudum ius Quiritium). Terminado o prazo, o comprador pode defender o seu direito fazendo uso de uma actio Publiciana. ${ }^{314}$

O poder que adquire o dominus sobre o fundus remonta à primordia civitatis - ao momento em que o solo romano foi dividido legitimamente, ou seja, com base no direito augural -, e é próprio da condição de cidadão, membro do populus. ${ }^{315}$

No que diz respeito à referência ao direito augural, trata-se de uma teoria nova, a nosso ver em grande medida apropriada, mas que requer maior desenvolvimento. ${ }^{316}$

Embora tenha feito um grande trabalho de pesquisa sobre os vocábulos auctor e auctoritas, acreditamos que a teoria de F. J. CASINOS-MORA apenas sintetiza as descobertas da mesma linha de pesquisa «publicista», que vai de LÉVY-BRUHL a FUENTESECA.

Essas teses se aproximam mais dos resultados de nossa pesquisa, a serem expostos nos capítulos seguintes.

Internazionale Pisa-Viareggio-Lucca, 17-21 aprile, 1990, t. 1, Milano, Giuffrè, 1991, p.117. A sua crítica se dirige ao que ele chama, com razão, "la visione pandettistica» de MOMMSEN e GIRARD, que obscureceram historicamente o significado da auctoritas, atribuindo-a à idéia da garantia contra a evicção. Em um escrito anterior, o autor já havia feito crítica semelhante, embora houvesse atribuído, erroneamente, a Girard, a vinculação entre auctoritas e mancipatio (Mancipium - mancipatio dominium, in Mnemeion Solazzi, p. 79). Essa associação já fora feita por Cujácio, e foi academicamente introduzida por MOMMSEN e aprofundada pelo trabalho de HUSCHKE.

${ }^{314}$ Idem, p. 112. Essas afirmações, a nosso ver, só se aplicariam ao direito posterior.

${ }^{315}$ Essa explicação é semelhante à de LEIFER, mas muito mais rica.

${ }^{316} \mathrm{O}$ que esperamos fazer adiante, todavia rejeitando parcialmente a teoria de FUENTESECA. Falta-lhe um enquadramento detalhado da auctoritas no contexto da propriedade arcaica. 


\section{Elementos para a interpretação da regra do usus auctoritas no direito decenviral (pré-história do usucapião)}

Vimos que a discussão sobre a interpretação do adágio decenviral, conservado por Cícero através de uma formulação, ao que tudo indica, bastante próxima ao original (segundo nossa hipotética reconstrução ortográfica, realizada adiante: OISSOS AVCTORITAS FVNDOI BIENNIOM ESTOD), girou sempre em torno de duas possibilidades: ou a auctoritas (1) traduz a idéia de posse/posição jurídica de poder, indiscutibilidade ou legimidade de um direito à coisa (domínio), ou (2) ela é um dos aspectos de um regime durante o qual aquele que detém a coisa goza da garantia contra evicção do seu transmissor. Ambas as teses - evidentemente aqui apresentadas de forma simplificada, mas que traduzem dois pontos de partida diversos -, como vimos, têm muitas variações, parcialmente contraditórias entre si.

Novo estudo sobre um assunto que continua «ancora oggi ad essere uno dei più tormentati della scienza romanistica ${ }^{317}$ necessita chamar a atenção para um aspecto ainda não cogitado. Pretendemos fazê-lo nas páginas a seguir.

Não podemos deixar de partir do pressuposto de que a regra decenviral do usus auctoritas é - embora tenha, como veremos, características bastante peculiares, em conformidade com o seu contexto arcaico - uma antecessora do usucapião clássico (partilhando, portanto, em geral da auto-evidente teoria tradicional). Essa é a interpretação de Cícero e Gaio, os próprios transmissores da regra de que falamos, que em nenhum momento falam em uma garantia do mancipio dans, e não mencionam diretamente nada que lembre eviç̧ão; sendo eles nosso elo de comunicação mais confiável com as XII tábuas, não é lícito sair desses limites. Esse é o erro da linha "garantista», embora não o único. ${ }^{318}$

\footnotetext{
${ }^{317}$ F. J. CASINOS-MORA, Auctoritas rerum decenviralis cit., p. 47.

${ }^{318}$ Como veremos, os fundi não eram objeto de mancipium no período decenviral, em razão de uma incompatibilidade estrutural; assim, não há sentido em associar à mancipatio a regra do usus auctoritas fundi.
} 
Se nos inserimos na tradição que associa o usus auctoritas à aquisição de fundi $i^{319}$ - já que, segundo transmissão de Cícero, não se fala em auctoritas, mas apenas em usus, quando se menciona as demais coisas, cetera res -, teremos de realizar um trabalho do qual pouco se ocuparam os autores que participaram do debate a respeito da interpretação dessa regra: esquadrinhar os inícios da propriedade fundiária romana, o sistema de limitação augural dentro do qual ela se insere e investigar o conteúdo arcaico do meum esse ex iure Quiritium.

Com isso, seguimos um princípio esboçado pelo próprio Gaio para a interpretação da lei das XII tábuas: facturus legum vetustarum interpretationem necessarius prius ab urbis initiis repetendum existimavi, non quia velim verbosos commentarios facere, sed quod in omnibus rebus animadverto id perfectum esse, quod ex omnibus suis partibus constaret: et certe cuiusque rei potissima pars principium est. ${ }^{320}$

Dada a complexidade do tema, fazemos uso do seguinte método: ao invés de realizarmos um estudo sistemático e cronológico, examinamos em cada item um aspecto aparentemente isolado do problema da «propriedade imobiliária» romana arcaica, movendo-nos entre o período pré-decenviral e o período das XII tábuas, e só ao final - no próximo capítulo - definimos as questões anteriormente deixadas em aberto, fixando, de modo inequívoco, a nossa interpretação do adágio decenviral.

\subsection{As terras objeto do usus decenviral. Contexto histórico do adágio usus auctoritas}

Se queremos apreender, com maior probabilidade de acerto, o significado da norma decenviral do usus auctoritas, será necessário prosseguir na pesquisa com um esboço da origem e de certas características da propriedade fundiária arcaica, em consonância com o que as fontes e a ciência histórica e

319 Cf. T. MAYER-MALY, Studien zur Frühgeschichte der usucapio // cit., p. 223: «der insofern durch Cicero gut gesicherte Originaltext der zwölf Tafeln [sprach] nur von fundi».

${ }^{320}$ Gai. 1 ad leg. XII tab., D. 1, 2, 1 pr. 
romanística nos podem fornecer. Qualquer tentativa de definir um instituto em um estágio inicial de desenvolvimento - mesmo para fins jusromanísticos, como é o nosso caso - não pode, com efeito, prescindir desse tipo de contextualização.

Dizemos para fins jusromanísticos, ${ }^{321}$ mais especificamente de direito privado, ${ }^{322}$ porque a nossa intenção não é simplesmente realizar uma descrição histórica daquilo que chamaríamos o "pré-usucapião», existente já antes da lex XII tabularum, mas sim revisitar e, se necessário, reformular parcialmente esse instituto do ponto de vista do seu desenvolvimento inicial, de acordo com novos dados e relações obtidos a partir da pesquisa histórico-dogmática. ${ }^{323}$

Um conhecido romanista, ao iniciar importante capítulo sobre a sua teoria da propriedade no direito romano, começou por chamar a atenção para os doze séculos de desenvolvimento desse direito: Roma inicia-se como uma pequena comunidade rural e chega ao seu auge como soberana de toda a Europa à época conhecida, de modo que, ao mencionar a propriedade romana, é preciso naturalmente perguntar-se: «si parla di quella di Romolo o piuttosto di quella di Giustiniano?». ${ }^{324}$

O conceito de dominium geralmente assumido pela romanística ao estudar o direito arcaico nada mais é do que uma projeção anacrônica, muitas vezes sem nenhum reparo, do direito clássico, cuja idéia de propriedade é resultado de um longo processo. Incorre em um anacronismo semelhante quem aplica esse conceito

\footnotetext{
${ }^{321}$ No sentido em que o define A. GUARINO, Giusromanistica elementare, Napoli, Jovene, 1989, p. 11, de «scienza... volta allo studio del ius Romanorum, cioè del diritto che há avuto vigore in Roma antica e nel mondo romano». O autor chama a atenção para a vocação contemporânea para o estudo do direito arcaico e do direito privado em geral (p. 36), marcada por uma intensa e crítica preocupação com as fontes (p. 37-38, 65-73).

322 Tendo em vista também a antiga e importante divisão entre «Römische Rechtsgeschichte» e «System des römischen Privatrechts» recordada por U. VON LüBTOW, Die Bedeutung des römischen Rechts für unsere Rechtskultur, Rheinfelden-Freiburg-Berlin, Schäuble, 1989, p. 15. Para uma descrição da estreita união entre o passado e o presente do direito privado, v. idem, p. 64-65, 68-74. Cf. também J. G. LAUTNER, Zur Bedeutung des römischen Rechts für die europäische Rechtskultur und zu seiner Stellung im Rechtsunterricht, Zürich, Juris, 1976, p. 115-122, sobre as relações entre a história do direito e a dogmática jurídica.

${ }^{323}$ Nosso objeto formal de estudo, portanto, não é o mesmo visado pelo arqueologia, embora acidentalmente tire proveito dos resultados obtidos nesse campo; esse objeto vem a ser, mais exatamente, o mesmo instituto referido pelos manuais de direito privado romano como "usucapião decenviral». O efeito de uma tal pesquisa, caso bem sucedida, será apenas propor uma correção parcial da visão da doutrina sobre o instituto.

${ }^{324}$ V. SCIALOJA, Teoria della proprietà nel diritto romano, Roma, A. Sampaolesi, 1928, p. 242.
} 
clássico de dominium ao direito justinianeu. No mesmo sentido é a afirmação de CAPOGRASSI de que não existe algo como a "propriedade» em termos gerais e abstratos. ${ }^{325}$ (Nosso ponto de partida, em termos semelhantes, como veremos mais tarde, é que não há um usucapião em sentido geral em abstrato, fora de contexto, especialmente no período decenviral).

Basta pensar na hipótese cogitada por G. ARCHI, por exemplo, de que entre os primeiros romanos a relação entre uma pessoa e a terra pudesse ser, não de natureza econômica, mas de ordem administrativa ou militar, semelhante àquela em vigor no regime feudal. Semelhantemente, nas monarquias orientais a soberania territorial e a propriedade do solo se identificam; o «proprietário» tem uma certa relação - certamente não de dominium, no sentido clássico - com a terra, mas ela está vinculada a uma concessão do soberano. ${ }^{326}$

Com efeito, no século $V$ a.C pareciam conviver duas formas de uso do solo. Em primeiro lugar vinha a posse que em tempos pré-cívicos teria sido gentílico $^{327}$ do ager publicus romanus, de caráter talvez não propriamente

${ }^{325}$ Agricoltura, diritto, proprietà, in Rivista di diritto agrario 1 (1952), p. 271.

${ }^{326}$ Il concetto della proprietà nei diritti del mondo antico, in RIDA 6 (1959), p. 244.

327 O populus - mais tarde civitas - expressa a idéia de cidadania romana, e era constituído, inicialmente, por um certo número de famílias em sentido amplo, as gentes. Essas, por sua vez, eram constituídas por patres, os patrícios, e mais tarde por plebei (Gai. 1, 3: plebs a populo eo distat, quod populi appellatione universi cives significantur connumeratis etiam patriciis, plebis autem appellatione sine patriciis ceteri cives significantur). $\mathrm{O}$ uso do ager romanus pelas gentes - aqui apenas os patrícios - foi objeto de muitos estudos no séc. XX. Expressa o entendimento comum sobre o assunto F. SERRAo, Individuo, famiglia e società nell'época decemvirale, in Società e diritto nell'epoca decemvirale (Atti del convegno di diritto romano - Copanello 3-7 giugno 1984), Napoli, Ed. Scientifiche Italiane, 1988, pp. 86, 107-108, ao dizer que a economia do séc. V a.C é constituída prevalentemente da exploração do ager publicus, quase todo ele nas mãos dos patrícios; eles constituem um corpo político soberano que - como é característico da sociedade gentílica - possui e controla a terra pelo fato de "possuir o Estado», segundo o princípio de que cada um possui aquilo que tem capacidade de cultivar. Mas para ele (F. SERRAO, Diritto privato, economia e società nella storia di Roma I - Dalla società gentilizia alle origini dell'economia schiavistica, Napoli, Jovene, 2006, p. 45-46), a existência de uma propriedade coletiva por parte das gentes só pode ser afirmada antes da formação da civitas, no chamado período pré-cívico; com a fundação da cidade, teria surgido a primeira forma de propriedade privada dos patres familiarum, e ao mesmo tempo, ainda no período régio, as gentes perderiam já o seu caráter de "gruppo compatto». Nesse sentido, F. BozzA, Il possesso I, Napoli, Jovene, 1935, p. 22-24, observa que, na passagem de Paul. 54 ad Ed., D. 41, 2, 1 pr: Possessio appellata est, ut et Labeo ait, a sedibus quasi positio, quia naturaliter tenetur ab eo qui ei insistit, quam Graeci катохท̀v dicunt, Labeão teria dito na verdade a sedibus patruum quasi positio, sendo que o vocábulo patruum teria sido retirado pelos tribonianos («Labeone faceva derivare la denominazione di possessio dal fatto che su i terreni, oggetto di possessio, avevano le sedi i patrici, cioè le gentes», idem, p. 24). Anote-se que, embora seja adequado falar em mera possessio dos patrícios sobre o ager publicus, e não de propriedade, esse vocábulo pode ter sido usado apenas posteriormente. Essa 
«coletivista», mas ao menos limitada pelo interesse comum; ${ }^{328}$ em seguida vinha a propriedade familiar dos heredia por quem era sui juris, mais próximo de uma idéia «individualista» de propriedade, embora de modo algum idêntica. ${ }^{329}$ Além disso, uma

descrição histórica da posse gentilícia tem propriamente início - com as suas peculiaridades -, todavia, com a conhecida obra de G. B. NIEBUHR, Römische Geschichte I, Berlin, G. Reimer, 1853, pp. 236-254; o historiador alemão acreditava, segundo a minuciosa interpretação de L. CAPOGROSSI COLOGNESI, 'Ager publicus' e 'ager gentilicus' nella riflessione storiografica moderna, in Proprietà e signoria in Roma antica I, 2. ${ }^{\text {a }}$ ed., Roma, La Sapienza, 1994, p. 108, nt. 20, numa orgânica conexão entre a possessio do ager publicus por parte dos patrícios e a concessão da propriedade privada dos heredia como exclusiva dos plebeus; essa intuição torna-se mais coerente com as considerações de R. VON JHERING, Geist des römischen Rechts auf den verschiedenen Stufen seiner Entwicklung I, 8. ${ }^{a}$ ed., Leipzig, Breitkopf \& Härtel, 1924, pp. 197-200, que atribui aos patrícios uma verdadeira propriedade do ager publicus, embora limitada pelo interesse comum (nem uma negação da propriedade, nem uma identificação com uma forma de apropriação individualista). Mais recentemente, além da contribuição de F. BozzA, já citada, que insistiu em uma contraposição ager publicus / ager em propriedade privada como uma constante do ordenamento romano, afirmando a existência de uma propriedade gentilícia sobre a terra (mais tarde desenvolvidas em possessiones do ager publicus) (II possesso cit., esp. p. 196), temos os estudos de KASER, WIEACKER e DIÒSDI. A opinião do primeiro é que a primeira forma de propriedade do solo (Bodeneigentum) foi a gentilícia, de caráter publicista, e que mais tarde passou ao Estado; essa comunidade agrária original, como também pensava MOMMSEN, não exclui a presença de uma propriedade individual, que gradualmente ganha importância e mais tarde predomina sobre o modo público de apropriação do solo (Eigentum und Besitz cit., p. 228-238; nesta última: «Ursprünglich war aller Boden ager publicus, aber schichtweise wurden seit früher Zeit große Stücke daraus in ager privatus verwandelt»). Opondo-se a uma projeção anacrônica da propriedade de tipo clássico, segundo o modelo da Pandectística, sobre o direito antigo, F. WIEACKER, Entwicklungsstufen des römischen Eigentums, in Vom römischen Recht - Zehn Versuche, 2. ${ }^{\text {a }}$ ed., Stuttgart, Koehler, 1961, pp. 187-221, sustenta, no mesmo sentido, que os romanos antigos ocuparam o solo a modo de Gemeineigentum, cujo fundamento estaria na autonomia dos grupos gentílicos pré-estatais, mais tarde substituída pela propriedade familiar (pp. 205-206). G. DıósDI, Ownership in Ancient and Preclassical Roman Law cit., p. 37-38, apenas reforça a tese de MOMMSEN (estudaremos a sua teoria sobre o heredium mais adiante).

${ }^{328}$ O episódio da gens Claudia é, embora nebuloso, uma ilustração clássica da posse gentilícia do ager Romanus. Os Tarquínios incitavam os sabinos a brandir armas contra os romanos e, sendo Cláudio um influente sabino, foi obrigado a fugir a Roma em razão de um processo movido contra ele tendo como fundamento a sua posição intransigente contra a guerra; chegando a Roma com seus bens e amigos, foi naturalmente bem recebido, e o senado e o povo romano o incluíram no número dos patrícios e the concederam uma grande porção de terra do ager publicus, como conta Dion. Hal.

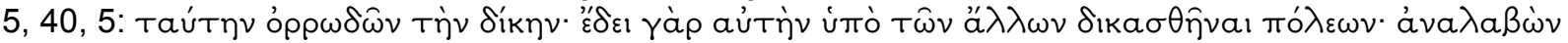

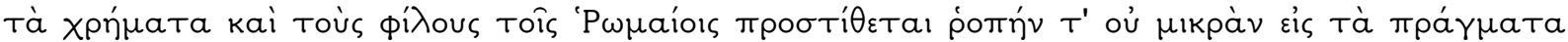

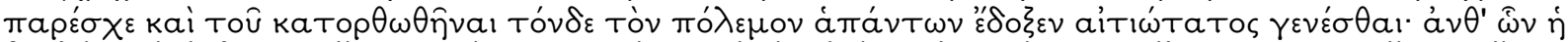

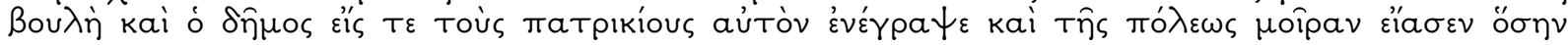

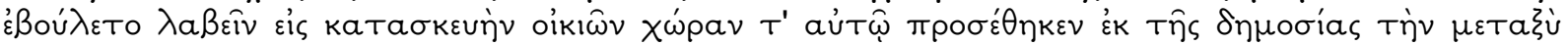

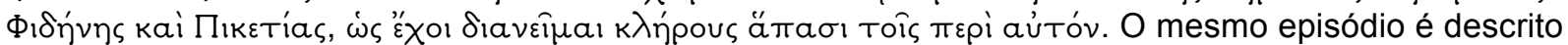
por Liv. 4, 3, 14.

${ }^{329}$ Evitaremos entrar na muitas vezes demasiado abstrata discussão sobre o status coletivista ou de regime de propriedade privada dos primeiros romanos. Cf. R. PöHLMANN, Geschichte der antiken Kommunismus und Sozialismus II, München, Beck, 1901, pp. 445-465, que, malgrado sua orientação ideológica, tende a admitir a propriedade individual, tese à qual também aderiu P. GUIRAUD, La propriété primitive à Rome, in Revue des études anciennes 4 (1909), p. 227. A autoridade historiográfica parece concordar em que, em certo sentido, a propriedade individual era amplamente difundida no séc. V a.C., e mesmo já no século anterior (cf. E. GJERSTAD, Early Rome IV - Historical 
parcela do solo era reservada para o sustento dos templos e altares, e outra era destinada ao uso comum, de acordo com uma importante passagem de Dionísio:

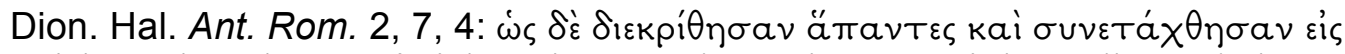

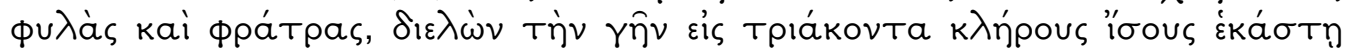

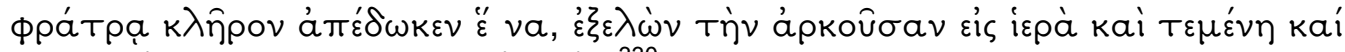

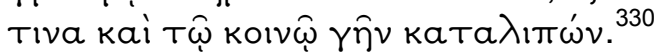

No que diz respeito aos heredia, segundo a tradição romana - que para efeitos jurídicos conta como referência estável dos romanos a uma mítica, mas efetiva, ${ }^{331}$ origo da propriedade fundiária exclusiva -, Rômulo teria atribuído a cada um dos cidadãos romanos, viritim civibus, mais exatamente o total de duas «jeiras» de terra (bina iugera), ${ }^{332}$ que constituíam, cada um, um heredium:

Var. de re rust. 1, 10, 2: Bina iugera, quot a Romulo primum divisa dicebantur viritim, quae haeredem sequerentur, heredium appellarunt. $^{333}$

Sucessivas redistribuições de terras conquistadas seriam feitas por Numa, ${ }^{334}$ Túlio Ostílio ${ }^{335}$ e Anco Márcio. ${ }^{336} \mathrm{E}$, mais tarde, numa singular ocasião em

Survey, Lund, Berlingska, 1973, p. 173). De qualquer forma, isso é pressuposto pelas XII tábuas. A questão que nos tange investigar é se essa propriedade individual incidia sobre a própria terra, como hoje entendemos, e como os romanos da época clássica o entendiam, ou apenas sobre o antigo heredium, sobre o qual teremos ocasião de discorrer adiante.

330 «Tendo sido portanto o povo dividido e vinculado às tribos e cúrias, [Rômulo] dividiu a terra em trinta porções iguais e atribuiu cada uma delas a uma cúria, tendo em primeiro lugar reservado o quanto fosse suficiente para o sustento dos templos e altares e também uma parte para 0 uso comum». V. também Varr. de ling. lat. 5, 55.

${ }^{331}$ Para o caso vale a observação de G. K. CHESTERTON: «Fable is more historical than fact, because fact tells us about one man, and fable tells us about a million men» (Varied Types, New York, Dodd, Mead and Company, 1908, p. 201).

332 Cf. R. PALmER, The Archaic Community of the Romans, Cambridge, Cambridge University, 1970, 32-33. Contra a idéia utópica de uma distribuição paritária, E. GABBA, Per la tradizione dell'heredium romuleo, in Roma arcaica - Storia e storiografia, Roma, Edizioni di Storia e Letteratura, 2000, p. 227234.

${ }^{333} \mathrm{E}$. COSTA acredita que, de fato, essa adsignatio aos paterfamilias tenha sido o mais antigo entre os modos de aquisição do dominium (Cicerone Giurisconsulto I, Bologna, N. Zanichelli, 1927, p. 97), o que aceitamos com óbvias reservas. No mesmo sentido, A. Momigliano, Roma arcaica, Firenze, Sansoni, 1989, p. 38, dizendo ser provável que os bina iugera estivessem à base da distribuição colonial da terra.

${ }_{334}^{334}$ Plut. Num. 16.

${ }^{335}$ Dion. Hal. Ant. Rom. 3, 1, 4-5. 
que o território de Labici fora conquistado e transformado em colônia romana, o senado decidiu que 15.000 colonos seriam enviados até ela, e que cada um receberia exatamente bina iugera para cultivo. ${ }^{337}$

Trata-se de uma forma de propriedade de atribuição familiar e de pequena extensão, em contraposição à antiga posse gentilícia. ${ }^{338}$

Segundo o testemunho de Plínio, heredium significava, nas XII tábuas, hortus, jardim:

Plin. nat. hist. 19, 50: in XII tabulis legum nostrarum nusquam nominatur villa, semper in significatione ea hortus, in horti vero heredium.

Já Festo define heredium como praedium parvulum; ${ }^{339}$ em outra passagem, diz que o hortus compreende toda a propriedade, omnis villa. ${ }^{340}$

Uma hipótese seria que inicialmente heredium fosse uma parcela de terra e que, com o tempo, tenha passado a significar o praedium, a área construída sobre esse lote, ${ }^{341}$ o que faria pensar na vigência arcaica do princípio superficies solo cedit. $^{342}$

Entretanto, conjectura Mommsen, seguindo o testemunho de Plínio sobre as XII tábuas, que inicialmente o heredium teria sido uma propriedade sobre a casa e o jardim ou horto, e não sobre o próprio solo, a «terra arável», que pertenceria

\footnotetext{
${ }^{336}$ Cic. de re publ. 2, 33.

${ }^{337}$ Liv. 4, 47, 7: «Coloni ab urbe mille et quingenti missi bina iugera acceperunt». Também em 8, 21, 11: "bina iugera agri acceperunt», e uma adsignatio tardia da mesma medida em 31, 49, 5 . Outra similar atribuição em idem, 6, 16, 6: «bina iugera et semisses agri adsignati». E em Juvenal 14, 163: «tandem pro multis vix iugera bina dabantur vulneribus».

${ }^{338}$ A contraposição entre essa distribuição de heredia e a ocupação gentilícia do ager publicum é lembrada por Tito Lívio, que reproduz um discurso polêmico anti-patrício nos tempos que antecedem a instituição da lei Licínia Sestia: Liv. 6, 36, 11: [Palavras de Sextius e Licínio em favor da plebe] Auderentne postulare ut, cum bina iugera agri plebi dividerentur, ipsis [os patrícios] plus quingenta iugera habere licet, ut singuli prope trecentorum civium possiderent agros, plebeio homini vix ad tectum necessarium aut locum sepulturae suus pateret ager?. Um dado importante é que o historiador atribui apenas aos plebeus o uso da concessão romuleia dos bina iugera.

${ }_{339}$ Fest. 89.

${ }^{340}$ Fest. 91.

341 Th. Mommsen, Römisches Staatsrecht III.1, Leipzig, von S. Hirzel, 1887, p. 23, fala contrariamente ao que afirmará em seguida, i. e., que o heredium se limita à casa e ao horto - em um um pedaço de terra (Bodenstück) distribuído a título de Erbgut (heredium, bem hereditário)I

${ }^{342}$ Cf. especialmente M. KASER, Natürliche Eigentumserwerbsarten im altrömischen Recht, in SZ 65 (1947), p. 239; contra, T. MAYER-MALY, Studien zur Frühgeschichte der usucapio // cit., p. 223, nt. 11.
} 
à gens. Essa parte - casa e horto - constituiria a propriedade transmissível hereditariamente. Essa forma de apropriação sobre a área construída seria já um avanço numa época que, há pouco, não teria conhecido nenhuma forma de propriedade imobiliária. ${ }^{343}$

Clássico adversário dessa tese de MOMMSEN de uma «Privateigentum auf Haus und Garten beschränkt» é PöHLMANN, que afirma acertadamente que a tradição de Rômulo pesa em favor de uma posse da própria terra, não limitada apenas à casa e ao horto. ${ }^{344}$ Veremos nos itens seguintes que a questão não é tão simples, por envolver o antigo sistema de limitação romano.

Sobre o modo da posse/propriedade sobre a terra, eis o testemunho de Cícero: "[no tempo de Rômulo], o patrimônio se limitava à posse do gado e da terra». ${ }^{345}$ Acreditamos que esse é um indício de que os beneficiários do heredium só gozavam inicialmente de $u s u s^{346}$ sobre a terra ao redor pertencente à gens, ${ }^{347}$ e não de propriedade, embora aos poucos - como veremos mais adiante, pensando no período após a fundação de Roma - pudessem conquistar para si, em virtude do mesmo usus (e da auctoritas prévia), o direito exclusivo segundo o direito dos Quirites (meum esse). ${ }^{348}$ Entretanto, com respeito ao núcleo do heredium, trata-se de uma posse exclusiva e, ao que tudo indica, perpétua, uma vez que, nas palavras de Varrão já citadas, os bina iugera tornavam-se patrimônio hereditário (quae heredem sequerentur $=$ dem Erben zu folgern $)-$ Erbbesitz, na terminologia alemã. ${ }^{349}$

\footnotetext{
${ }^{343}$ Idem, pp. 23-24. No mesmo sentido, G. DIósDI, Ownership... cit., p. 39.

${ }^{344}$ Geschichte der sozialen Frage... I/ cit., p. 426.

345 «Tum erat res in pecore et locorum possessiones, ex quo pecuniosi et locupletes vocabantur» (de re pub. 2, 9).

${ }^{346}$ R. PöHLMANN, Geschichte der sozialen Frage... // cit., p. 416, interpreta res como verdadeira propriedade, alegando que Cícero normalmente usa o vocábulo possessio para se referir a essa idéia.

${ }^{347}$ Terra, locus, tem aqui provavelmente o sentido de ager: «hinc et locupletes dicebant loci, hoc est agri, plenos» (Plin. nat. hist. 18, 3, 11). De fato, se lemos juntamente os textos de Cícero e Plínio, temos de pensar em um verdadeiro usus loci. O próprio MoMmsen utiliza o vocábulo Bodennutzung.

${ }^{348}$ Essa idéia desenvolveremos em seguida.

${ }^{349}$ M. KASER, Eigentum und Besitz... cit., p. 235.
} 
E no mesmo sentido demonstra J. M. NAP que heredium equivalia, no sentido de Festo, ao prédio rústico (praedium rusticum), situado portanto para além dos muros da cidade e de propriedade exclusiva do pater. $^{350}$

Crê M. KASER que, quer a família tivesse a posse apenas da casa, quer também do solo, é razoável que - não sendo suficientes os dois iugera de terra - ela tivesse tido acesso à terra cultivável ao redor do heredium, como complemento para a sua subsistência. ${ }^{351}$

O fato de que apenas o heredium, o núcleo da posse familiar, fazia parte do patrimônio hereditário também falaria a favor da ausência - embora apenas antes da fundação de Roma - de um poder exclusivo e absoluto, por parte do heres ou paterfamilias, sobre o resto do solo ao redor. Essa situação parece ter sido bastante comum em tempos pré-cívicos, num ambiente em que a posse exclusiva sobre coisas móveis, e em menor grau sobre a casa, é algo muito mais imediato e intuitivo - mais evidente segundo a natureza das coisas - do que a posse do solo. ${ }^{352}$ O mesmo KASER argumenta - com reparos nossos - que esse «espaço vital» imediatista favorece a atitude de «deixar a terra sob a proteção» da auctoritas do poder soberano. $^{353}$

\footnotetext{
${ }^{350}$ Heredium en hortus in de twaalf tafelen, in TR 1 (1918-1919), p. 391. Discordamos do autor (seguindo, nesse aspecto, E. KAïLA, L'unité foncière em droit romain, Paris, B. de Boccard, 1927, pp. 28-30) apenas quando diz que o heredium em sentido estrito pudesse ser desde o início objeto de usucapião, uma vez que as fontes mostram ser a sua concessão exclusiva ao seu beneficiário como heres.

${ }^{351}$ Eigentum und Besitz... cit., p. 233.

352 K. SCHWARZE, Beiträge zur Geschichte altrömischer Agrarprobleme, Halle, M. Niemeyer, 1912, p. 20: «Individualgrundbesitz ist ursprunglich faktisch ausgeschlossen».

${ }^{353}$ Idem, p. 238. Transcrevemos o trecho devido à sua importância para o nosso raciocínio: «Darum steht dieser Lebensraum nicht im festen und gleichbleibenden Privateigentum des Einzelnen, sonder nur unter der politischen, zunächst außerrechtlichen, dann publizistisch gesehenen Hoheit der Verbände». Esse poder político, dado o contexto, assumiria um caráter evidentemente pessoal, nunca «público» ou administrativo em sentido tardio (nesse sentido, U. VON LÜBTOW, Das römische Volk Sein Staat und sein Recht, Frankfurt, V. Klostermann, 1955, p. 86, que afasta qualquer possibilidade de um «politisch-rationalen Kalküls» em favor da idéia de um "Gentilcharisma»). No mesmo sentido é F. DE MARTINO, Storia della costituzione romana I, 2. ${ }^{a}$ ed., Napoli, Jovene, 1972, p. 27, que sustenta que a lenda de Rômulo é uma recordação de fatos reais a respeito das origens da propriedade exclusiva do heredium ao lado da grande propriedade comum sobre o solo: sobre esta se estende o regime jurídico da originária propriedade coletiva do grupo e sobre os confins do heredium - e, mais tarde, sobre a área ao redor adquirida pelo cultivo - o poder do paterfamilias, num evidente contraste entre os antigos costumes e o direito quiritário. V. também L. WENGER, Von Staatsgewalt und Bürgerrecht im alten Rom, in SDHI 15 (1949), pp. 88-90.
} 
DE FRANSCICI coloca a questão nos seguintes termos: já que esse exíguo espaço territorial era insuficiente, mesmo para uma família pequena, como também assinalava KÜBLER, ${ }^{354}$ cada familia teria podido dispôr de uma parte do terreno pertencente à gens a fim de exercitar o pastoreio sobre uma parte da terra comum gentílica destinada a esse fim (ager compascuus). ${ }^{355-356}$ Isso inclui, de acordo com os dados que nos chegaram sobre a agricultura romana (já que ela era parte importante da economia do séc. V), o direito ao cultivo do ager. ${ }^{357}$ Solucionaremos $^{2}$ esse ponto mais adiante.

Como dizíamos, o ager publicus, no decorrer da sua expansão, era destinado a várias funções: o uso propriamente público; a ocupação por parte daqueles que podiam ocupá-lo e lavrá-lo; e o loteamento em favor de particulares, para uso exclusivo. Nesse meio tempo, vão surgindo várias formas jurídicas de apropriação, e assim definem-se e redefinem-se os limites e o conteúdo dos direitos, bem como as suas formas de defesa. ${ }^{358}$ Note-se que, no momento em que uma parcela do ager publicus era atribuída ou legimitamente ocupada por um particular, esta tornava-se posse privada. ${ }^{359}$

\footnotetext{
${ }^{354} R E$ 7, v. gens, p. 1182. Veja-se, entretanto, que o usus auctoritas previsto no período decenviral favorece a visão - que adotamos - de que avançou rapidamente em Roma a propriedade privada sobre a terra, o fundus, que compreendia o antigo heredium e mais parcelas de solo cultivável desde que conquistado pelo efetivo labor agrícola - ao redor. Detalharemos essa questão no item 3.

${ }^{355}$ Primordia civitatis, Romae, Apollinaris, 1959, p. 174. O autor ainda sublinha a importância dessa contiguidade territorial entre as famílias que habitavam, provavelmente, uma pequena vila (vicus) situada no território de um pagus gentílico; e que a senhoria das gentes não seria qualificável em termos privatísticos (p. 174-175).

${ }^{356}$ Cic. top. 12: Si ager compascuus est, ius est compascere.

357 Cf. F. SeRRAO, Diritto privato, economia e società... cit., p. 75, que ressalta o crescimento, já no séc. VI, da agricultura intensiva e aquela das pequenas fazendas familiares. Em outra passagem, o autor afirma que, após o estabelecimento da cidade de Roma, o ager desfrutado pelas gentes passa ao populus Romanus; diante dessa situação, a hipótese mais verossímil - a qual seguiremos aqui - é que o ager tivesse continuado como propriedade das gentes, portanto nem propriamente privado, nem público. Futuramente o ager dividir-se ia definitivamente entre cada grupo gentílico, tornando-se propriedade individual ou confundindo-se com o ager publicus. As provas de tal estado de coisas são: a) as disposições das XII tábuas com respeito à sucessão dos gentios, e. g., "SI AGNATUS NEC ESCIT, GENTILES FAMILIAM HABENTO» (XII Tab. V, 5); b) o episódio da concessão de um território à gens Claudia; c) a derivação gentilícia dos nomes das mais antigas tribos rurais (idem, p. 49).

358 Idem, p. 277.

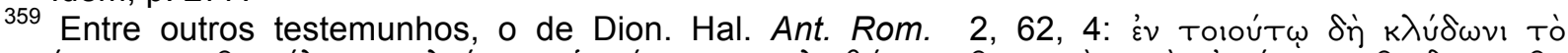

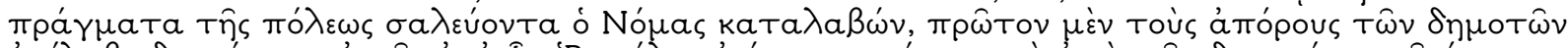

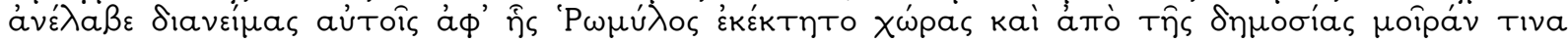
ó $\lambda_{i ́ \gamma \eta \nu}$ (Numa, tendo se deparado com tal confusão no estado de coisas político, primeiramente
} 
O que parece claro, segundo as fontes, é a recorrente distribuição de terras por parte dos reis, ${ }^{360}$ e mais tarde pelo populus Romanus em tempos republicanos.

Fato importante, como veremos, é que essas concessões e ocupações pressupõem a constituição de limites territoriais bastante determinados. Não é possível possuir uma terra, seja pública ou privada, ${ }^{361}$ sem limites, pois a limitação é um pressuposto da propriedade.

Antes de passar ao núcleo da nossa exposição, vejamos ainda mais uma característica da posse e da propriedade arcaica. Sículo Flaco, o agrimensor, recorda que, em antigos tempos, era contrário ao mos possuir (possidere) uma terra maior do que a capacidade do agricultor de a cultivar; e que num tempo posterior esse direito se estenderia àquilo que o agricultor tivesse esperança de cultivar: ${ }^{362}$

Sic. Flac. de cond. agr. (Lachmann 136): preterea legem tulit, nequis in Italia amplius quam ducenta iugera possideret: intellegebat enim contrarium esse morem, maiorem modum possidere quam qui ab ipso possidente coli possit. ${ }^{363}$

\footnotetext{
aliviou os pobres entre os plebeus distribuindo-Ihes uma pequena parte da terra que Rômulo havia possuído, bem como do do ager publicus).

${ }^{360}$ Plut. Num. 16; Dion. Hal. Ant. Rom. 3, 1, 4-5; Cic. de re publ. 2, 33; Liv. 4, 47, 7.

361 Já no tempo de Numa Pompílio, segundo Dion. Hal. Ant. Rom. 2, 74, 4: toûto $\delta^{\prime}$ oủk [a lei a

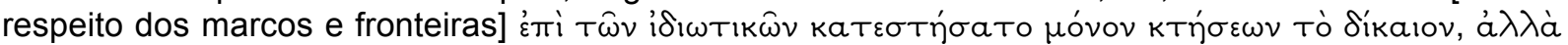

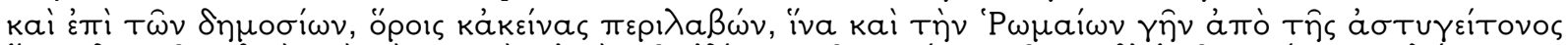

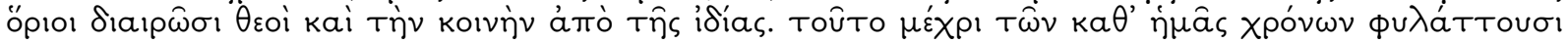

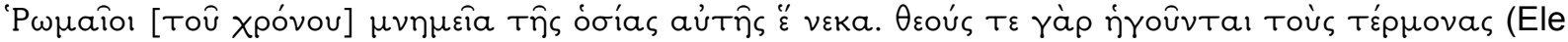
instituiu essa lei [a respeito dos marcos e fronteiras] referindo-se não só à posse privada, mas também àquela pertencente ao populus; porque estas ele também as marcou com pedras terminais, de modo que os deuses das fronteiras pudessem distinguir as terras dos romanos daquelas dos seus vizinhos, $\mathrm{e}$ as terras públicas daquelas que pertencessem aos particulares. Memória desse costume é observada pelos romanos até hoje, somente sob a forma religiosa).

${ }^{362}$ Isso, como veremos, impõe-se como princípio do «usucapião» decenviral: o regime da auctoritas só permite ao agricultor o ius colendi referente à terra corretamente ocupada, em usus, dentro dos limites consagrados do ager. Também em Columela, De re rust. 1, 3: flagitiosum (videbatur), quos hostis profugiendo desolasset agros, novo more civem Romanum supra vires patrimonii possidendo deserere.

${ }^{363}$ C. LACHMANN, Die Schriften der römischen Feldmesser I, Berlin, G. Reimer, 1848, p. 141; daqui em diante Lachmann seguido do número da página.
} 
Idem (Lachmann 137): singuli deinde terram, nec tantum occupaverunt quod colere potuisset, sed quantum in spem colendi reservavere.

Apesar de enventuais conflitos entre o mos e o direito quiritário, parecenos que esse princípio da capacitas colendi também se aplicaria, por uma imposição prática e econômica, às terras objeto de propriedade exclusiva (meum esse); ${ }^{364}$ até porque o direito costumeiro foi sempre observado, e muitas vezes simplesmente transformado em lei escrita. ${ }^{365}$

Como vimos, toda atribuição privada de terras, plena ou limitada, deriva de modos de propriedade comunitária da terra, em tempos pré-cívicos, e, após a fundação de Roma, da posse privada do ager publicus proveniente da concessão do Populus ou de ocupação legítima (provavelmente reservada aos patrícios). A posse limitada do ager era chamada possessio, e nunca perdia essa característica, sendo assim incompatível com os dados que temos sobre a usucapio; a posse também exclusiva, mas plena, do ager e da construção sobre ele (villa), viria a se configurar, no tempo decenviral, como possibilidade do titular afirmar que o fundus (ager e villa) é seu ex iure Quiritium.

Dois romanistas que recentemente estudaram com profundidade a questão da evolução dos modos de apropriação do solo no período arcaico, $\mathrm{F}$. SERRAO e F. FRANCIOSI, parecem fornecer um retrato fidedigno, embora discutível em parte, da situação fundiária romana dos primeiros tempos.

\footnotetext{
${ }^{364} \mathrm{O}$ uso da terra estava subordinada à fiscalização dos censores, mesmo aquela sob a posse exclusiva do particular; enquanto os magistrados respondem pelo ius, os censores prezam pela observância dos mores maiorum (Cf. M. KASER, Mores maiorum und Gewohnheitsrecht, in SZ 59 (1939), pp. 52-53; e do mesmo autor, Rechtswidrigkeit und Sittenwidrigkeit im klassichen römischen Recht, in SZ 60 (1940), p. 95).

${ }^{365}$ Por exemplo, Ulp. 1 Sab., D. 27, 10, 1 pr: Lege duodecim tabularum prodigo interdicitur bonorum suorum administratio, quod moribus quidem ab initio introductum est; Ulp. 7 Sab., D. 29, 2, 8 pr: More nostrae civitatis neque pupillus neque pupilla sine tutoris auctoritate obligati possunt; Pomp. 5 Sab., D. 23, 2, 8: Libertinus libertinam matrem aut sororem uxorem ducere non potest, quia hoc ius moribus, non legibus introductus est; Gai. 4, 26-28; PS. 5, 4, 6. Não é necessário aderir a M. KASER, Das altrömische lus... cit., pp. 53-63, que defende a separação de âmbitos ius / mos, ou a M. GUARINO, L'ordinamento giuridico romano... cit., p. 144-148, que defende a idéia de procedência do ius a partir do mos, cujas conclusões (de ambos os juristas) em linhas gerais não afetam nosso estudo.
} 
Este último afirma que, segundo a tradição, as XII tábuas teriam previsto um usucapião bienal para os fundi; mas, por outro lado, o ager publicus, do qual os fundi parecem proceder, não era objeto de usucapião. A sua resposta é que, sendo assim, apenas o heredium, «a única forma de propriedade imobiliária» à época, podia ser adquirido por usucapião. Aos poucos, acrescenta, a jurisprudência pontifícia teria alargado o conceito de usus, considerando digno de apropriação individual também o terreno ao redor da pequena propriedade. ${ }^{366}$

A descrição de SERRAO - um trabalho talvez sem precedentes de cotejo das fontes sobre a propriedade e a posse no período arcaico (pré-cívico e fundacional) -, embora não dê uma solução clara para o problema, parece também abrir espaço para a propriedade individual dos fundi.

Como já mencionamos, o ager publicus podia ser destinado ao (i) uso público, (ii) à administração da cidade, (iii) à ocupação por parte daqueles que, com base nos mores, podiam ocupá-lo e cultivá-lo (possessio do ager occupatorius) e, por fim, (iv) à apropriação exclusiva e garantida aos particulares. Esse é o confiável retrato de SERRAO, com forte apoio nas fontes, ${ }^{367}$ embora não leve em conta o sistema de limitação romano (esse elemento será estudado adiante).

Esta última forma - a única suscetível de apropriação exclusiva e plena - consiste numa concessão por parte do populus e, segundo as fontes, se limita

${ }^{366}$ G. FRANCIOSI, 'Gentiles familiam habento', in G. FRANCIOSI (org.), Richerche sulla organizatione gentilizia romana, Napoli, Jovene, 1995, p. 47. Alguns anos depois, o autor modificou radicalmente sua opinião, buscando uma saída totalmente nova para o problema, embora não o tenha dito expressamente. Em Per la storia dell'usucapione immobiliare in Roma antica, in SDHI 69 (2003), pp. 127-147, o autor coloca o terminus a quo da propriedade imobiliária exclusiva - especialmente no que diz respeito aos fundi - muitos anos depois da «primeira edição» da lei das XII tábuas. Segundo ele, a propriedade quiritária ainda está limitada, no séc. V a.C., aos bens móveis, enquanto as terras são todas ocupadas segundo o regime do desfrutamento do ager publicus; uma vez que não eram objeto de usucapio, o autor crê estar provado que a própria regra do usus auctoritas seria uma criação posterior da jurisprudência (por volta do ano 329 a.C., data em que se pode afirmar com certeza a presença de centúrias). $O$ termo de dois anos, diverso do que seria o termo geral para o usucapião de móveis, de um ano, seria motivado pela cultura rotativa dos fundi, e essa inovação - o biennium seria resultado de um longo processo interpretativo e de adaptação à realidade econômica (p. 133). Essa opinião demasiado radical não tem apoio na pesquisa histórica, como ficará claro no decorrer da nossa exposição. Acreditamos, com o autor, que o processo de privatização das terras romanas foi lento; mas, como veremos, ele já se inicia antes da edição da lei das XII tábuas; basta pensar nas inúmeras concessões de terra a título exclusivo feitas no período da Realeza e nos inícios da República, bem como na lex Icilia de Aventino, anterior à legislação decenviral, que pressupõe uma situação de apropriação exclusiva do solo.

${ }^{367}$ Diritto privato, economia e società... cit., p. 277. 
inicialmente aos bina iugera distribuídos no período da Realeza; isso nos obrigará, mais adiante, a investigar mais de perto o sistema que regia essas concessões (classicamente a centuriatio).

Os autores que sustentam a tradição do heredium de Rômulo são Varrão, Festo e Plínio. Mas Dionísio e Cícero ${ }^{368}$ apresentam um quadro da economia romana arcaica diferente, e mais coerente, no que se refere ao uso da terra: uma população dividida entre patrícios e plebeus, em que os primeiros dirigem os afazeres públicos e os segundos se ocupam da agricultura, subordinados, como clientes, àqueles. Nessa situação uma distribuição paritária de terra seria impensável. ${ }^{369}$

Os testemunhos já citados desses autores, e mais o de Lívio, permitem entrever um desenvolvimento das concessões «estatais» de terra: Numa Pompílio distribui à plebe parte da terra já possuída por Rômulo e uma parte do ager publicus, além de regular as fronteiras entre as terras públicas e privadas e instituir um cadastro fundiário; Túlio Ostílio distribui outras terras - que anteriormente pertenciam aos reis, conquistadas na guerra - aos cidadãos que não tinham agri; Anco Márcio concede mais terras; certo agrum captum ex hostibus é distribuído aos cidadãos por Sérvio, enquanto o jovem Tarquínio ainda reinava, a fim de conquistar a boa vontade do povo. ${ }^{370}$ Essas concessões se estendem pelo período republicano, ${ }^{371}$ e marcam a origem e a evolução da propriedade privada individual procedente do ager publicus. ${ }^{372}$

Os destinatários dessas concessões são sempre plebeus ou cidadãos pobres desprovidos de terra; os patrícios gozam do benefício da possessio do ager publicus, segundo o slogan «a propriedade é plebéia; a possessio é patrícia». ${ }^{373}$

\footnotetext{
368 Dion. Hal. Ant. Rom. 2, 9; Cic. de re publ. 2, 14, 26, já citados.

369 Já citamos o entendimento de E. GABBA, Per la tradizione dell'heredium... cit., 227-234, segundo o qual «le strutture della 'colonia' fondata da Romolo non prevedono alcuna assegnazione paritaria della terra» (p. 234).

${ }^{370}$ Liv. 1, 46, 1: Servius quamquam iam usu haud dubie regnum possederat, tamen quia inderdum iactari voces a iuvene Tarquinio audiebat se iniussu populi regnare, conciliata prius voluntate plebis agro capto ex hostibus viritim diviso ausus est ferre ad populum, vellent iuberentne se regnare.

${ }^{371}$ V. a exposição de SERRAO, Diritto privato, economia e società... cit., p. 280-282.

372 Idem, p. 283.

${ }^{373}$ Idem, ibidem.
} 
O conteúdo do direito dos beneficiários, no período decenviral, é o meum esse, segundo a terminologia processual da legis actio sacramenti in rem. Por isso, a terra concedida é alienável ${ }^{374}$ e sujeita a aquisição pelo usus (mais tarde usucapio - embora tenhamos reparos a fazer a essa formulação; v. adiante). Muito embora acerte na descrição do usus, SERRAO equivoca-se quanto ao significado do termos auctoritas. ${ }^{375}$

Pensamos que as concessões de terra republicanas excediam os limites do heredium; e mesmo que o beneficiário só recebesse inicialmente uma parcela de bina iugera, pode-se afirmar com segurança que, segundo os seus meios econômicos, pudesse conquistar pelo usus - pelo cultivo - uma maior parcela de terra arável, desde que houvessem parcelas disponíveis. ${ }^{376}$ Cremos, entretanto, que o núcleo constituído pelo heredium mommseniano - a casa e o horto - fosse possivelmente inalienável inter vivos, de acordo com as fontes já mencionadas. ${ }^{377}$

Isso permite mostrar a relação direta que há entre o heredium romuleu, mais tarde expandido pela força laboral dos agricultores, e o fundus decenviral, que compreendia a villa e o ager (em contexto familiar, a integridade do fundus era

\footnotetext{
${ }^{374}$ Nisso, o autor combate a tese de MOMMSEN sobre a inalienabilidade do heredium. Defendemos parcialmente essa tese adiante.

375 Idem, p. 284, 321-322.

${ }^{376}$ De fato, a mesma hipótese é levantada por C. W. WESTRUP, mas com relação ao ager gentílico: segundo ele, é provável que mesmo antes das XII tábuas o ager pertencente em comum teria sido dividido entre as gentes para uso temporário, e que com o tempo cada família teria conquistado pelo uso (usus auctoritas), em virtude de um «direito proveniente do trabalho» (working-right), a propriedade privada de uma parcela de terra (Introduction to Early Roman Law II - Joint Family and Family Property, Copenhagen-London, E. Munksgaard-Oxford University, 1934, p. 56). A inalienabilidade do heredium como patrimônio hereditário teria a sua base na crença de que ela é «herdada dos antepassados» e devia permanecer nas mãos da família e, se possível, aumentada. No antigo direito de algumas cidades gregas, o patrimônio familar também não podia ser vendido (Arist.

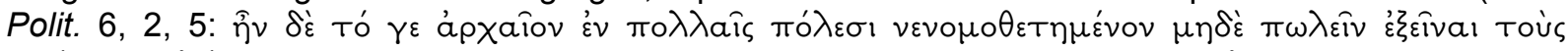

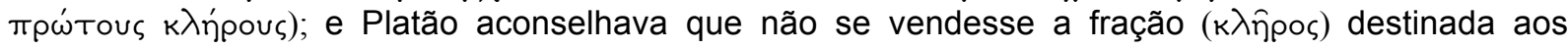
antepassados (Leg. 5, 741b). No direito decenviral, toda a área ao redor do túmulo dos ancestrais, FORVM... BVSTVMVE, não podia ser adquirida pelo usus (XII Tab. X, 10; v. também Fest. 74: cum id forum antiqui appellabant, quod nunc vestibulum sepulcri dicari solet, e 29: bustum proprie dicitur locus, in quo mortuus est combustus et sepultus); e consta que os mortos fossem enterrados justamente na parcela de terreno junto ao heredium (idem, p. 96-97).

377 E. CUQ, Études sur le droit babylonien - les lois assyriennes et les lois hittites, Paris, P. Geuthner, 1929 , p. 77 , demonstra ter a propriedade fundiária babilônica atravessado o mesmo desenvolvimento, da propriedade familiar comum, dotada de um núcleo inalienável, à propriedade individual livremente alienável.
} 
chamada domus). ${ }^{378} \mathrm{O}$ usus era exercitado sobre ambos (usus fundi $=$ usus villae agrique). ${ }^{379}$

Podemos dizer, portanto, que nesse contexto o usus decenviral, precursor do usucapião, tinha como objeto principal uma parcela correspondente ao heredium (como veremos, um usus segundo o modus atribuído na adsignatio, o heredium em sentido ideal) e outras parcelas delimitadas do ager romanus e concedidas pelo populus às famílias, na pessoa do pater. ${ }^{380}$

Isso constitui, evidentemente, uma vitória dos plebeus, beneficiados por um gradual processo de privatização - transformação de parte do ager publicus em ager privatus ${ }^{381}$ - do solo romano. ${ }^{382}$ Tese semelhante já fora sustentada por $\mathrm{E}$. CUQ. ${ }^{383}$

${ }^{378}$ M. VoIGT, Das Civil- und Criminalrecht der XII Tafeln II, Leipzig, A. B. Liebeskind, 1883, p. 7, nt. 2, para as fontes.

${ }^{379}$ Ou aedes fundusve (top. 26, 100), conforme a sugestão de B. ALBANESE, Usus auctoritas fundi in XII Tab. 6, 3 secondo le testimonianze di Cicerone, in Annali del Seminario Giuridico della Università di Palermo XLV.1 (1998), p. 31.

${ }^{380}$ F. SERRAo, Individuo, famiglia e società... cit., p. 87. A mesma opinião fora sustentada de passagem por C. W. WESTRUP, Introduction to Early Roman Law II cit., p. 56, e passou praticamente despercebida pela doutrina. Embora o autor se refira ao ager gentílico, num contexto que parece valer para o período pré-cívico, reproduzimos a sua afirmação, uma vez que projeta uma grande luz sobre a interpretação do adágio do usus auctoritas que temos desenvolvido: «Already prior to the Code of the XII Tables, a division - among the individual families (domus) of each gens - of the agri hitherto belonging jointly to the gentes must have begun to take place. After a probably at first merely periodical allotment of land in certain definite plots for the temporary enjoyment of each domus, the gentilician agri gradually by use (usus auctoritas), in virtue of a working-right, passed definitely into the exclusive private possession of the individual families». Cremos que, seja ou não correta a reconstrução histórica da relação entre as gens e o solo pré-romano, a interpretação de WESTRUP é plenamente válida - embora mereça reparos e acréscimos importantes, os quais serão feitos mais tarde - para o período da Realeza e da primeira República.

${ }^{381}$ Cf. Cic. de leg. agr. 3, 7, 10-11: «[ager] optimo iure privatus». E também Gai. 2, 41: «Si tibi rem mancipi neque mancipavero neque in iure cessero sed tantum tradidero, in bonis quidem tuis ea res efficitur, ex iure Quiritium vero mea permanebit, donec tu eam possidendo usucapias».

${ }^{382}$ Segundo M. WEBER, a idéia de aquisição pelo usus seria já um rompimento com a antiga ordem agrária, ligada a uma economia comunitária, em virtude dessa atribuição particular do solo (Die römische Agrargeschichte... cit., p. 184). A afirmação não é exata, como veremos adiante. $O$ autor vê na época que vai de Sérvio à publicação da lei das XII tábuas um período de emancipação da propriedade do solo, e na própria legislação decenviral o momento de definitiva segmentação do solo comunitário em propriedade privada (p. 193).

${ }^{383}$ Les institutions juridiques des romains $1,2 .^{\text {a }}$ ed., Paris, Plon, 1904, p. 75-76. O autor dizia, mesmo sem acesso à volumosa literatura que se produziria no correr do século $\mathrm{XX}$, que o heredium representa o início da propriedade fundiária entre os romanos, embora fosse inalienável entre vivos. Ele está delimitado e consagrado ao deus Terminus. Com o passar do tempo, o ager gentílico vai passando às mãos dos patrícios, que o cultivam conforme os meios de que dispunham; e assim se introduz a idéia de que cada homem adquire o direito ao uso exclusivo da terra pela sua força de trabalho. O direito quiritário então passa a reconhecer, a quem cultivou a terra por dois anos, a 
A chamada lex Icilia de Aventino publicando, de 456 a.C, ilustra muito bem essa situação, ${ }^{384}$ e permite entender certo aspecto do estado de coisas em Roma poucos anos antes da publicação da legislação decenviral. Conforme o testemunho de Dionísio, que até hoje permanece inconteste, ela estava afixada ainda no tempo do próprio Dionísio - numa estela de bronze no templo de Diana sobre o Aventino, e dispunha o seguinte:

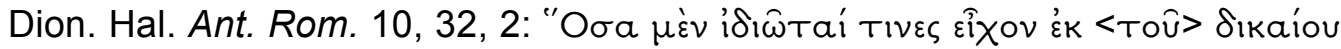

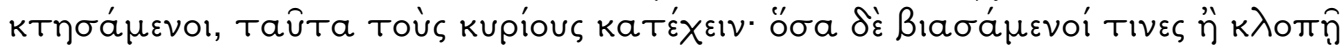

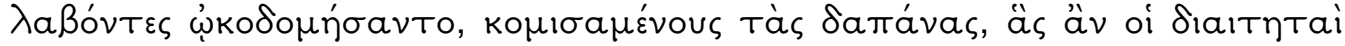

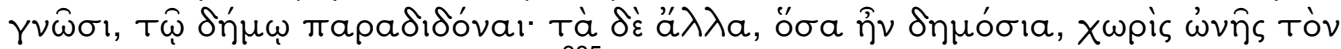

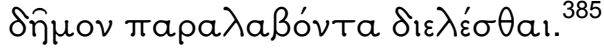

Segundo a lei, portanto, certa parte da terra do Aventino estava nas mãos de cidadãos privados; Dionísio afirma expressamente que essa parcela fora

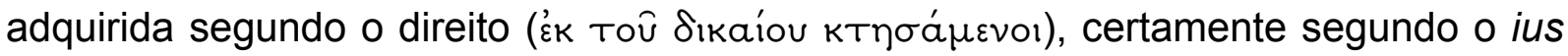
Quiritium, ou seja, segundo o ius proprium civium Romanorum existente já antes da publicação da legislação decenviral, que apenas veio tornar certo, determinado, um direito costumeiro cujas bases eram incertas (sine iure certo), como disse Pompônio. ${ }^{386}$ Deste modo, deveria permanecer nas mãos dos seus proprietários.

propriedade exclusiva, e o direito sobre o ager é assimilado ao direito sobre o heredium. Se é verdade que o Estado, diz o autor, concedeu aos primeiros habitantes a sua casa com um jardim, foram eles que adquiriram para si, pelo trabalho, grandes parcelas das terras anteriormente pertencentes às gentes. Veremos que esse esquema, se razoavelmente modificado, confirma-se com o estudo do sistema de limitação (item 4.3).

${ }^{384}$ Favorável à idéia de que essa lei beneficia os plebeus é Liv. 3, 67, 11; e 7, 40, 12.

385 «As porções de terra pertencentes, se adquiridas segundo o direito, aos cidadãos privados, devem continuar nas mãos dos seus senhores; as parcelas sobre as quais certas pessoas, tendo-as ocupado pela força ou tendo-as possuído com fraude, edificaram, devem ser restituídas ao povo, sendo garantido que os atuais ocupantes serão indenizados pelas despesas, segundo aferição do árbitro; as outras parcelas, sendo pertencentes ao populus, serão concedidas gratuitamente à plebe, que as

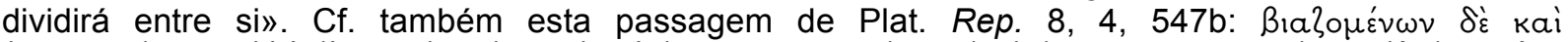

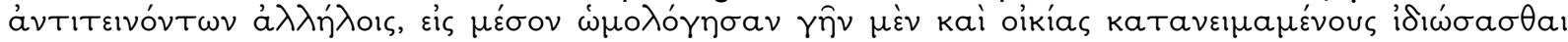
(Mas depois, grandes conflitos e oposições recíprocas, puseram-se de acordo a respeito da repartição da terra e de casas a título privado...), embora em contexto alegórico.

${ }^{386}$ Pomp. Ench., D. 1, 2, 2, 1: Et quidem initio civitatis nostrae populus sine lege certa, sine iure certo primum agere instituit omniaque manu a regibus gubernantur. 
Cremos que essa «aquisição segundo o direito» - e não «divisão», como está na tradução de F. SERRAO, ${ }^{387}$ em desacordo com o texto grego mencionada pela lex Icilia de Aventino reporta-se à aquisição de um modus agri (possivelmente originária) e ao usus legítimo nesses limites, de acordo com a possibilidade de cada agricultor-proprietário (quantum colere prasenti tempore poterat). ${ }^{388-389}$

A oposição entre as terras adquiridas segundo o direito e as terras ocupadas mediante fraude ou violência lembra, efetivamente, a futura exigência, no que se refere ao instituto do usucapião clássico, da boa-fé por parte do possuidor, um requisito criado jurisprudencialmente. Isso indica que, embora seja omisso a esse respeito o dispositivo sobre o usus das XII tábuas, era de acordo com o mos considerar ilegítima - como é de justiça natural, por assim dizer - a posse violenta ou

${ }^{387}$ Diritto privato, economia e società... cit., p. 119. O verbo ктฤ $\sigma a ́ \mu \varepsilon v o$ deve ser traduzido segundo o sentido original de "adquirir», e não admite a idéia de distribuição ou divisão. Cf. LIDDELL-SCOTT, $A$ Greek-English Lexicon (ed. 1996), v. KTỏoual: «procure for oneself, get, acquire».

${ }^{388}$ Nesse exato sentido, F. SeRRAO, Diritto privato, economia e società... cit., p. 120 . O autor ainda

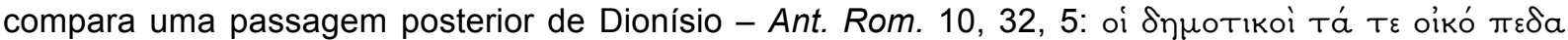

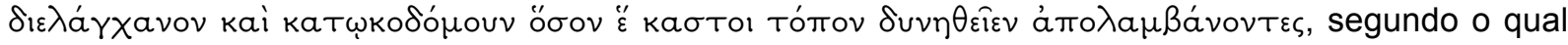
os plebeus, após a concessão dos lotes de terra, começaram a construir sobre eles, cada um segundo a sua capacidade, ocupando a maior parcela de terra de que fosse capaz - com o antigo costume que regulava a posse da terra segundo a capacitas colendi, referido por Columella e Sículo Flacco e já comentado por nós (F. SERRAO, Lotte per la terra e per la casa a Roma, in Legge e società nella repubblica romana 1 , Napoli, Jovene, 1981, p. 126, nt. 185). Entretanto, A. MANZO, La lex Licinia Sextia de modo agrorum - Lotte e leggi agrarie tra il V e il IV secolo a.C, Napoli, Jovene, 2001, p. 76, tem razão ao afirmar que não é perfeitamente identificável o conceito de capacitas colendi com o de capacitas aedificandi (seguindo A. BURDESE, resenha a G. Falcone, Richerche sull'origine dell'interdetto uti possidetis, in SDHI 62 (1996), p. 589). Entretanto, é bastante verossímil que se trate de um reflexo do antigo costume - que, ao contrário do que afirma D. MANTOVANI, L'occupazione dell'ager publicus e le sue regole prima del 367 a.C, in Athenaeum 85 (1997), p. 593, não é um fato descritivo, mencionado de passagem pelos agrimensores, mas sim um dado normativo - sobre a lex Icilia de Aventino.

${ }^{389}$ Isso não exclui que parte dessas terras tenham sido, após a sua consolidação nas mãos de uma família, objeto de transmissão inter vivos por mancipatio. Acreditamos, seguindo Gai. 2, 41, que a mancipatio (aquisição por mancipium) dispensava a aquisição pelo vsvs, já que quem recebia a coisa mancipi podia imeditamente afirmar que esta era sua ex iure Quiritium. Não se pode, entretanto, excluir a fortíssima probabilidade de que não fosse possível inicialmente transferir a propriedade de um fundus por mancipium, segundo a hipótese levantada por C. W. WESTRUP, Introduction to Early Roman Law... cit., p. 49, e defendida por E. CUQ, Les institutions juridiques des romains cit., p. 75; basta pensar na oposição entre manu capere, aquilo que se pode apreender com a mão (Gai. 1, 121: «mancipatio dicitur, quia manu res capitur»), e usu capere, aquilo que se adquire pelo usus. A ação mais antiga ligada à propriedade, a legis actio sacramento in re, pressupunha que o objeto fosse apreendido com a mão $($ Gai. 4,17$)$. Sobre esse assunto, v. o próximo item. 
fraudulenta, e assim impossível o reconhecimento "segundo o direito» de terra por assim dizer subtraída de alguém, às claras ou clandestinamente. ${ }^{390}$

A regularização da propriedade exclusiva, nesse contexto, é ainda o aspecto prático, o modo particular de apropriação individual do ager romano - um modo de atribuição de algo que era considerado patrimônio do populus e que agora passa a ser um meio de subsistência sob o domínio das famílias,$-{ }^{391}$ grande parte dele anteriormente conquistado pela guerra contra os povos vizinhos, ex hostibus captum. $^{392}$

Veremos que esse processo de privatização do solo romano é muito mais complexo, pois envolve o sistema de limitação augural, sobre o qual falaremos mais tarde. ${ }^{393}$

Procuremos, antes disso, investigar mais de perto o fundamento e alguns aspectos desse regime de propriedade exclusiva.

\subsection{O fundamento quiritário do alicuius esse}

Evitemos, antes de mais nada, utilizar o vocábulo «propriedade» em sentido clássico ou moderno. ${ }^{394}$ A atribuição exclusiva de um bem no direito arcaico, incluindo o período pré-decenviral, reduzia-se à possibilidade de se poder afirmar que a coisa pertence a alguém: meum est no sentido mais simples de «Zueigenhaben», ${ }^{395}$ ter para mim, e de poder agir como se a coisa fosse minha. ${ }^{396} \mathrm{~A}$ idéia geral de propriedade supõe maior abstração (abstração havia, mas peculiar). ${ }^{397}$

\footnotetext{
${ }^{390}$ Compare-se essa situação com a contemplada pela lex Atinia de usucapione, que constitui um paralelo interessante.

${ }^{391}$ Como veremos adiante, a atribuição do meum esse ex iure Quiritium é uma forma de participação no poder do populus, e não está em conflito com ele.

392 Gai. 4, 16: «maxima sua esse credebant, quae ex hostibus cepissent», que sugere uma origem bélica para a propriedade. B. W. LEIST, Alt-arisches Jus Civile II, Jena, G. Fischer, 1896, p. 42, a respeito da origem da propriedade fundiária em geral dentro da sua teoria do direito indogermânico: «Der Grund des Habens des einzelnen Grundstücks is dann doch immer, daß der Stamm den ganzen District in Besitz genommen hat und kriegsmässig vertheidigt». A expressão agrum ex hostibus captum é justamente a utilizada por Lívio, na passagem citada acima, para indicar a parcela de terra concedida aos cidadãos por Sérvio.

${ }^{393} \mathrm{~V}$. item 4.3.

${ }^{394}$ Embora utilizemos o vocábulo, procuramos empregá-lo dentro do contexto correto.

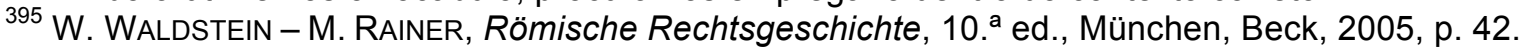


Inicialmente, essa afirmação estava associada a coisas bastante tangíveis, circunscritas à esfera familiar (escravos, animais, instrumentos agrícolas, $\operatorname{armas}^{398}$ ), e a sua conservação dependia da chamada autotutela.

Mais cedo ou mais tarde, essa afirmação aparece nas fontes referindose ao fundus. ${ }^{399}$ Uma antiga oração utilizada na lustratio da terra ainda no tempo de Catão faz referência à expressão fundus meus, o que é um bom indício da sua antigüidade: «Mars pater, te precor quaesoque, uti sies volens propitius mihi domo familiaque nostrae: quoius rei ergo, agrum terram fundumque meum suouitaurilia circumagi iussi, etc.». ${ }^{400-401}$

Todavia, como dizíamos, essa idéia arcaica de pertencimento (meum est) permite uma associação direta com coisas que a mão pode tocar e apreender, ${ }^{402}$ nos parece um pouco distante do fundus. Isso está de acordo com o fato de que a propriedade fundiária surge, assim em Roma como em outras sociedades arcaicas,

\footnotetext{
${ }^{396}$ Um segundo aspecto dessa idéia arcaica de pertença, como veremos adiante, é a possibilidade de invocar a proteção dos Quirites.

397 Assim também no direito germânico antigo - e na língua correspondente -, que não conhecia nenhum substantivo para propriedade (cf. os autores citados em M. VoIGT, Civil- und Criminalrecht... cit., p. 87, nt. 13).

${ }^{398}$ Para uma visão arqueológica, cf. D. RIDGWAY - F. R. RIDGWAY (ed.), Italy Before the Romans - The Iron Age, Orientalizing and Etruscan periods, London - New York - San Francisco, Academic, 1979, pp. 15-16.

${ }^{399}$ Nada impede, entretanto, que em certa época ou situação se fizesse referência ao heredium como totalidade da qual faria parte a casa e o ager, como sustenta M. VOIGT, Civil- und Criminalrecht der XII Tafeln II cit., p. 335. É restritiva a qualificação de Festo (Paul. Diac.) do heredium como praedium parvulum, e acaba por dar uma idéia da extensão do heredium incompatível com a inclusão do fundus; no mesmo sentido o já citado Flor. 8 inst., D. 50, 16, 211: 'fundi' appellatione omne aedificium et omnis ager continetur. Nossa tendência, de qualquer modo, é usar como padrão do heredium uma totalidade, e pensar sempre num modus agri que lhe serve de fundamento.

${ }^{400}$ Cat. de agr. cult. 141, 2, que contém o resto dessa oração. O trecho citado segue-se à parte inicial: "cum divis volentibus quodque bene eveniat, mando tibi, Mani, uti illace suouitaurilia fundum agrum terramque meam, quota ex parte sive circumagi sive circumferenda censeas, uti cures lustrare».

${ }^{401}$ Cf. R. TILL, Die Sprache Catos, Leipzig, Dieterich, 1935, pp. 2-12; sobre a estrutura geral do livro de Catão, cf. W. RICHTER, Gegenständliches Denken archaisches Ordnen - Untersuchungen zur Anlage von Cato de agri cultura, Heidelberg, C. Winter, 1978, pp. 7-17. Cf. também, a respeito dessa passagem e fórmula, J. HöRLE, Catos Hausbücher - Analyse seiner Schrift De Agricultura nebst Wiederherstellung seines Kelterhauses und Guthofes, Paderborn, F. Schöningh, 1929, pp. 39-40; O. SchönBerger, Marcus Porcius Cato - Vom Landbau, Fragmente, Darmstadt, Wissenschaftliche Buchgesellschaft, 1980, pp. 560-562; G. WissoWA, Religion und Kultus der Römer, 2. ${ }^{a}$ ed., München, Beck, 1912, pp. 142-143; Fest. 210.

${ }_{402}$ Por exemplo na interessante passagem de Plaut. Rud. 4, 3: ecquem esse dices in mare piscem meum? Quos quom capio, si quidem cepi, mei sunt: habeo pro meis nec manu adseruntur. A aquisição de coisa nullius é talvez um dos exemplos mais claros da intuitividade da pertença legítima por simples apreensão.
} 
muito depois da propriedade sobre bens móveis, e que começa sempre com uma adsignatio por parte de um soberano.

A primeira noção de poder sobre pessoas e coisas diretamente sob o domínio do pater - mulher, filhos, ${ }^{403}$ escravos, $^{404}$ res privata em geral ${ }^{405}$ - era expresso com a palavra manus. ${ }^{406}$ Trata-se da simples associação entre a mão e a possibilidade de segurar fisicamente a coisa e mantê-la consigo.

Mas essa noção não se aplica ao fundus, justamente em razão da impossibilidade da sua apreensão direta, manu adprehendere. Para a alienação de coisas mancipi, mesmo no tempo de Gaio, era necessário que a coisa estivesse presente, de modo que aquele que recebia mancipio pudesse apreendê-la fisicamente, como é da essência do mancipium (manu res capitur). ${ }^{407}$ Isso, a propósito, mostra a estreita relação que há entre a manus, com um sentido ativo, e o mancipium (aqui manu captum), com um sentido passivo; nesse contexto, o meum

${ }^{403}$ Inst. 1, 12, 6: Filios suos vel filias... sua manu dimittere; Liv. 34, 2, 11: feminas... in manu esse parentum, fratrum, virorum; Nov. 81, c. 1 pr: úंò

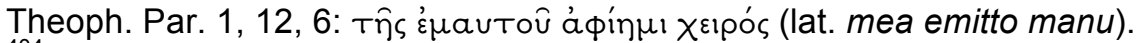

${ }^{404}$ Ulp. 1 Inst., D. 1, 1, 4: Est manumissio de manu missio; Plaut. Curc. 4, 2, 10: manus alienos emittis.

405 Plaut. Merc. 2, 3, 454: Illi suam rem esse aequomst in manu. O diálogo refere-se a uma escrava, mas o contexto dessa fala é geral: "ele deve ter controle sobre as suas coisas».

${ }^{406}$ Disputa-se sobre o objeto original da manus: se a mulher, no contexto do poder marital apenas, ou as demais pessoas e/ou coisas da casa. Segundo P. KOSCHAKER, Eheformen bei den Indogermanen, Berlin, W. de Gruyter, 1937, p. 82, a manus originalmente, ao que parece, se estendia a tudo o que pertencia à casa, e mais tarde limitou-se ao poder marital («eheherrlich Gewalt»). Semelhantemente, MANIGK, verb. manus in RE 14, p. 1377, sustenta a sua compreensão original também para além dos limites da patria potestas, apesar de inclui-la («Hausgewalt, Herrschaft und Autorität schlechthin»); trata-se da origem do poder familiar, e representava o domínio do paterfamilias sobre a mulher como marido, sobre os filhos como pai, e sobre os escravos como proprietário. Apenas para o perído clássico vale a distinção de Gai. 1, 49: «Sed rursus earum personarum quae alieno iuri subiectae sunt alieae in potestate, aliae in manu, aliae in mancipio sunt». No mesmo sentido, L. WENGER, Hausgewalt und Staatsgewalt im römischen Altertum, in Miscellanea Fr. Ehrle II, p. 24, esclarecia que, na língua dos romanos, manus significava, originalmente, todo poder doméstico, seja sobre pessoas, seja sobre coisas. A discussão não se tem renovado; a mesma idéia permanece em W. KUNKEL/H. HONSELL, Römisches Privatrecht cit., p. 63: manus original = «Hausgewalt des pater familias», mais tarde restrita ao poder sobre a mulher; a patria potestas está reservada ao poder sobre os filhos e netos.

407 Gai. 1, 121: In eo solo praediorum mancipatio a ceterorum mancipatione differt, quod personae serviles et liberae, item animalia quae mancipi sunt, nisi in praesentia sint, mancipari non possunt; adeo quidem, ut eum, <qui> mancipio accipit, adprehendere id ipsum quod ei mancipio datur, necesse sit; unde etiam mancipatio dicitur, quia manu res capitur; praedia vero absentia solent mancipari. Cf. ainda Varr. de ling. lat. 6, 85: mancipium, quod manu capitur; Isid. Orig. 9, 4: mancipium est quidquid manu capi, qui subdique potest, ut homo, equus, ovis. Haec enim animalia statim ut nata sunt, mancipium esse putantur. Nam et ea, quae in bestiarum numero sunt, tunc videntur mancipium esse, quando capi sive domari coeperint. 
esse representa a atribuição exclusiva em sentido estático, sem referência ao poder dinâmico sobre a coisa. ${ }^{408}$

É certo que Gaio, no fragmento citado, é testemunha da possibilidade de alienação dos praedia no seu tempo (praedio vero absentia solent mancipari). ${ }^{409}$ Mas para o período decenviral é inimaginável um uso tão largo - a ponto de contrariar frontalmente a essência do mancipium - desse modo de aquisição. Há uma grande distância entre a simples transferência, mesmo solene, de uma coisa que se tem diante de si, e que é imediatamente apreendida pelo adquirente (traço essencial do antigo direito quiritário, com raízes por assim dizer pré-jurídicas), e a transmissão da propriedade de um fundus - ou de vários simultaneamente, sem qualquer limitação, como ocorre no período clássico -, que não se pode apreender. ${ }^{410}$

Essa situação absurda levou muitos juristas, com razão, a circunscreverem o papel do mancipium arcaico (também no sentido de transferência, cláss. mancipatio) às coisas fisicamente apreensíveis, ${ }^{411}$ opinião que consideramos correta. O testemunho de Festo (Paul. Diac.) tem também um certo peso, ao atribuir

${ }^{408}$ Cf. toda a discussão e bibiografia a esse respeito em C. BREZZO, La mancipatio, Roma, L'Erma di Bretschneider, 1972, p. 8-10, nt. 24.

${ }^{409}$ O mesmo diz Ulp. Reg. 19, 6: Res mobiles non nisi praesentes mancipari possunt, et non plures quam quot manu capi possunt; immobiles autem etiam plures simul, et quae diversis locis sunt, mancipari possunt.

${ }^{410} \mathrm{O}$ contraste pode ser ilustrado observando-se a terminologia de Ulpiano no fragmento citado acima: no que diz respeito às res mobiles, só é possível alienar quantas coisas a mão pudesse capturar; já as coisas immobiles, quase sempre de maior valor, podem ser objeto de uma alienação múltipla, de terras situadas em vários lugares distintos, sem qualquer limitação. A radical alteração da antiga ordem jurídica sobre o mancipium, obra de juristas que precederam Gaio e Ulpiano, é algo indiscutível. Cf. P. KRETSChMAR, Das Nexum und sein Verhältnis zum Mancipium, in SZ 29 (1908), p. 233 , nt. 1.

${ }^{411}$ T. MommSEn, Römische Geschichte I cit., p. 154; E. CUQ, Instituitions juridiques des romains I cit., p. 270; K. F. THORMANN, Die doppelte ursprung der mancipatio - Ein Beitrag zur Erforschung des frührömischen Rechtes unter Mitberücksichtigung des nexum, München, Beck, 1943, p. 65, nt. 14; C. BReZzo, La mancipatio cit., p. 12, nt. 34; P. KRETSCHMAR, Das Nexum und sein Verhältnis zum Mancipium cit., p. 233, nt. 1; W. KUNKEL, verb. mancipatio in RE 14, p. 1009; P. F. GIRARD, R. VON MAYR, Geschichte und System des römischen Rechtes 1, Berlin, F. Vahlen, 1908, p. 312, nt. 2; L. MITTEIS, Römisches Privatrecht - bis auf die Zeit Diokletians I - Grundbegriffe und Lehre von den Juristischen Personen, Leipzig, Duncker \& Humblot, 1908, pp. 257-258; P. FUENTESECA, Trasferimento della proprietà... cit., p. 83; F. GALLO, Studi sulla distinzione fra res mancipi e res nec mancipi, Torino, G. Giappichelli, 1958, p. 158; WESTRUP, Introduction to Early Roman Law II... cit., p. 49, como hipótese duvidosa; em outro artigo, Notes sur la sponsio et le nexum dans l'ancien droit romain - Le nouveau fragment des Institutes de Gaius, København, E. Munksgaard, 1947, p. 12, a mesma hipótese parece ter sido aceita, tendo o mancipium como primeiro objeto os escravos (cf. também, do mesmo autor, Propriété primitive, in $R H 12$ (1933), p. 233). 
ao vocábulo manceps - procedente da forma mais primitiva MANVCAPIOM - ${ }^{412}$ a mesma idéia de «qui manu capit», transmitindo-nos a opinião aparentemente unânime dos escritores antigos. ${ }^{413}$

Não se pode negar que no período clássico os fundi in agro Romano eram considerados res mancipi. Mas é um indício interessante o fato de que aparecem por último na lista de Gaio. ${ }^{414}$ Percebe-se com isso a passagem, certamente tardia, de uma idéia concreta de manus para uma idéia simbólica desse poder (envolvendo abstração, analogia e extensão), que permite a inclusão do fundus. ${ }^{415}$

Uma pergunta conexa que é necessário responder é se os fundi eram, por esse motivo, inalienáveis na época decenviral. $O$ negócio classicamente chamado mancipatio ${ }^{416}$ está, de alguma forma, presente nas XII tábuas. ${ }^{417} \mathrm{O}$

${ }^{412}$ A. WALDE, J. B. HofMANN, Lateinisches etymologisches Wörterbuch cit., p. 23, *man-caps, -capiom. ${ }^{413}$ Fest. Paul. Diac. 115. Cf. M. VoIGT, Civil- und Criminalrecht... cit., p. 127-128, nt. 4.

${ }^{414}$ Gaio fala primeiro das pessoas in mancipio, depois de coisas mancipi móveis, e só então acrescenta: item praedia tam urbana quam rustica quae et ipsa mancipi sunt (Gai. 1, 116; 120). Perceba-se o uso do item e do quae et ipsa, que falam a favor da excepcionalidade da situação.

${ }^{415}$ C. BREZZO, La mancipatio cit., p. 12.

${ }^{416}$ H. H. PfLÜGER, Nexum und mancipium, Leipzig, Duncker \& Humblot, 1908, p. 40, afirma que as XII tábuas conhecem apenas um negócio per aes et libram (chamado nessa lei «nexum mancipiumque», cf. nota abaixo), que só mais tarde seria conhecido como mancipatio.

417 Basta recorrer à disposição: CVM NEXVM FACIET MANCIPIVMQUE, VTI LINGUA NVNCVPASSIT ITA IVS ESTO (VI, 1); quia et mancipationem et in iure cessionem lex VII tabularum confirma\{n\}t (Paul. Vat. 50). Esse fragmento decenviral foi objeto de muitas polêmicas. A tese clássica é que o mancipium faz referência à apreensão do objeto adquirido: HVNC HOMINEM EX IVRE QUIRITIVM MEVM ESSE AIO (Gai. 1, 119), e o nexum ao negócio libral, ou ao menos ao seu efeito vinculante expresso pela afirmação do adquirente: ISQVE MIHI EMPTVS ESTO HOC AERE AENEAQVE LIBRA. Segundo a mesma tese, a expressão NEXVM MANCIPIVMQVE é uma unidade que representa a aquisição quiritária de uma coisa pelo pagamento de um preço (O. LENEL, Das Nexum, in SZ 23 (1902), p. 88). A palavra mancipium, sem mais, poderia indicar apenas o ato de apreensão («der Akt mit Handgriff»), enquanto nexum em sentido estrito seria o negócio libral (quodcumque per aes et libram geritur), que não continha necessariamente o ato de manu adprehendere (Cf. M. KRETSCHMAR, Das Nexum und sein Verhältnis zum Mancipium cit., pp. 239 e 279), o que parece ser a opinião de Q. Múcio na passagem de Varr. de ling. lat. 7, 105: Nexum Manilius scribit omne quod per libram et aes geritur, in quo sint mancipia. Mucius, quae per aes et libram fiant, ut obligentur, praeter quam mancipio detur. Hoc verius esse ipsum verbum ostendit, de quo quaerit: nam idem quod obligatur per libram neque suum fit, inde nexum dictum, à qual Varrão adere (todavia, deve-se levar em conta os reparos de O. LENEL, Das Nexum cit., pp. 95-96). Os últimos trabalhos sobre o tema não alteraram essencialmente a visão de LENEL sobre o nexum; todavia, cf. sobretudo O. BEHRENDS, Das nexum im Mancipationsrecht oder die Ungeschichtlichkeit des Liberaldarlehens, in RIDA 21 (1973), pp. 137-184, opositor do aspecto creditício do nexum («Darlehn»), cuja teoria sobre o nexum facere decenviral expomos logo abaixo; mas também U. voN LüBtow, Zum Nexumproblem, in SZ 67 (1950), p. 112-161; P. NoAILLES, Nexum, in RH 19-20 (1940/41), pp. 205-274; P. KosCHAKER, resenha da obra anterior, in SZ 63 (1943), p. 460. Os termos do debate - que constituem a origem da pesquisa científica sobre o nexum - foram colocados por 
significado essencial do mancipium, entretanto, como vimos, é um claro obstáculo. ${ }^{418}$ A única saída seria, à primeira vista, a teoria formulada por O. BEHRENDS - a qual apresentamos apenas como hipótese,$-{ }^{419}$ que vê na expressão nexum facere contida na disposição decenviral $(\mathrm{VI}, 1)$ o particular modo de delimitação privada e alienação dos fundi. ${ }^{420}$

HUSCHKE no séc. XIX (Über das Recht des Nexum und das alte römische Schuldrecht - Eine rechtshistorische Untersuchung, Leipzig, Gebauer, 1846, pp. 1-48 especialmente); ele concebeu o ato per aes et libram como um negócio capaz de produzir dois efeitos: um real, que se consubstancia na transferência da propriedade pela mancipatio, e um obrigacional, ou seja, um contrato criado pelo nexum de caráter público, em razão das testemunhas e do libripens presente ao ato; além disso, pela nuncupatio, o credor pronuncia uma damnatio contra o devedor, e aquele pode mover contra este, em caso de não pagamento, uma actio per manus injectionem. A inclusão da damnatio foi combatida por L. MITTEIS (cf. ); este contrapôs o nexum, capaz de criar obrigações (Varr. De ling. lat., 7, 105), aos nexi mencionados por outros textos (referentes a devedores incapazes de pagar e que se vendiam a si mesmos aos credores, praticando uma espécie de auto-mancipatio), e afirmou que a ação concernente ao nexum é o sacramentum in personam, tendente a produzir um judicatus. Seguem-se três artigos suscitados pelo de MITTEIS: o de LENEL, já citado, que reforça a oposição de MITTEIS à idéia huschkeana da damnatio e da manus injectio judicati; o de E. I. BEKKER, Über die Objekte und die Kraft der Schuldverhältnisse - Geschichtliche Überschau, von der Zeit der Manusinjektion bis in die Gegenwart, in SZ 23 (1902), pp. 1-30, que defende a teoria de HUSCHKE, observando que o aes podia ter tanto a função de transferência (mancipatio) como a de crédito (nexum), e defendendo a possibilidade da damnatio; e por fim o de T. MOMMSEN, Nexum, in SZ 23 (1902), pp. 348-355, afirmando que o nexum é na verdade um contrato de mutuum acompanhado de uma mancipatio condicional do devedor, que desde o início entra na esfera in mancipio do credor. Para uma bibliografia inicial a respeito dessa controvérsia, com cerca de 60 artigos e passagens sobre o assunto, cf. P. NoAlLlES, Nexum cit., pp. 14-15, nt. 2; uma bibliografia mais recente e bastante completa pode ser encontrada em M. KASER, Das römische Privatrecht I cit., p. 166, nt. 2.

${ }^{418}$ Como explica P. FuENTESECA, Trasferimento della proprietà... cit., p. 83 e 87, o fundus não podia ser objeto de mancipatio dado que não era possível a sua apreensão e submissão doméstica; assim, só podia ser objeto de aquisição pelo usus (usu capere). A sua explicação do papel da auctoritas, entretanto, como elo de união entre a mancipatio e o usus nos parece equivocada.

${ }^{419} \mathrm{O}$ que significa, mesmo fossem os fundi inalienáveis também através do nexum, salvaguardar nossa tese geral sobre a interpretação do adágio do usus auctoritas - em essência, a nossa explicação da aquisição dos fundi pelo usus e a da significação da auctoritas não se apóia, e não é afetada, por essa hipótese.

${ }^{420}$ Formulada com prudência em Das nexum im Mancipationsrecht... cit., pp. 173-184, e desenvolvida com certa ousadia em La mancipatio nelle XII tavole, in IVRA 33 (1982), pp. 84-103. Primeiramente o autor nota, com razão, que o mancipium facere, por estar ligado ao Handgriff, não é compatível com a alienação de terras. Já que não há espaço para a mancipatio de terras no conceito de mancipium facere das XII tábuas, resta recorrer, no que diz respeito aos fundi, à expressão nexum facere contida no mesmo dispositivo; pois nexum é o termo geral para a mancipatio (conhecida com esse nome, entretanto, no período pós-decenviral), a qual compreende também a transferência dos fundi, segundo as fontes (Das nexum im Mancipationsrecht... cit., pp. 173-174). Aí estaria implícita uma forma negocial adequada para a transferência dessa categoria de coisas. $O$ uso do nexum facere para a alienação de terrenos estaria comprovado em duas passagens: a) Agennius Urbicus, Lachmann 63: Et stipendiarios [agros] qui nexum non habent, neque possidendo ab alio quaeri possunt, possidentur tamen a privatis, sed alia condicione: et veneunt, sed nec mancipatio eorum legitima potest esse; b) Gai. 2, 27 (ed. Studemund-Krüger 1927): <admo>nendi sumus... esse, provincialis soli nexum non esse... significationem solum <lt>ali<cu>m mancipi <est>, provincialis nec mancipi est. aliter enim veteri lingua a... (interessante a reconstrução de P. F. GIRARD - F. SENN, Textes de droit romain I, 7. ${ }^{a}$ 
ed., Paris, Dalloz, 1967, p. 69, que acolheu a proposta de DAVID-NeLSON, Studia Gaiana III (1960), p. 252: Praterea admonendi sumus, quod veteres dicebant soli Italici nexum esse, provincialis soli nexum non esse, hanc habere significationem solum Italicum mancipi esse, provinciale nec mancipi esse; aliter enim lingua nexus vocari solebat id quod nobis est mancipatio). O autor especula que, ao lado do ritual da apreensão física de coisas móveis macipi, haveria um «Hegungsritual» tornado efetivo através de um vínculo (nectere). Ele oferece dois fundamentos para essa afirmação: a) o direito pontifical teria ao menos elaborado um equivalente («Ersatzform») para a forma fixada em lei para a transferência de terrenos; b) ficaria sem objeto a demarcação junto à transferência de um fundus fora dos seus limites demarcados e considerados sagrados (idem, pp. 176-177). O núcleo da teoria de BEHRENDS é a idéia de que a raiz etimológica de nexum (nectere) teria de ter um sentido adequado à transferência de fundi; em outras palavras: embora as fontes não forneçam uma descrição do nexum facere de imóveis, é praticamente necessário que houvesse originalmente uma forma de transferência de acordo com o sentido de nectere, vincular, ligar (idem, p. 178). O autor ainda recorre a um outro argumento, seguindo a mesma pista. Trata-se da idéia de "anexação», ligada à aquisição aditiva de novas parcelas de terra (loci) a um fundus já existente. Partindo do fragmento: si eum alii adiunxerimus fundo, locus fundi efficietur (Ulp. 69 ad ed., D. 50, 16, 60 pr), o autor especula a respeito da possível expressão locum fundo adnectere, que tem certo apoio nas fontes (Plin. Nat. Hist. 3, 8, 1: nona regio annectitur septimae; Pomp. Mel. de chorogr. 2, 15: Sicilia aliquando... continens et agro Bruttio adnexa). Em tempos mais antigos, não se poderia imaginar, diz o autor, fosse possível anexar a um fundus uma parcela do solo gentílico sem uma justificação ritual. Uma passagem de Festo a respeito do direito pontifício fornece um indício interessante da conexão entre os funiculi, cordas com as quais os agrimensores determinavam os confins de uma propriedade privada, e a ação de adnectere (Fest. 160: Nectere ligare significat, et est apud plurumos auctores frequens; quin etiam in commentario sacrorum usurpator hoc modo: 'Pontifex minor ex stramentis napuras nectito', id est funiculos facito, quibus sues adnectantur). Num artigo posterior, em que toma realmente como pressupostos os resultados dessa pesquisa, o autor define o nexum facere como modo de alienação dos fundi que compreendia, num sentido concreto, a delimitação e a medição do terreno a ser vendido por meio de uma corda ou fio (funiculus) (La mancipatio nelle XII tavole cit., p. 81). Essa seria a noção mais antiga, científica por assim dizer, do termo nexum, corretamente utilizada pelos agrimensores; a noção mais comum, entretanto, e que nos foi transmitida por Gélio, Varrão e Cícero, entre outros, é a de um gênero que inclui a mancipatio e todos os negócios librais (solutio per aes et libram, nexi liberatio, coemptio e testamentum libral). Aquele significado original de nexum não era apenas o de mancipatio fundi, mas o de algo ainda mais restrito, constistindo numa técnica pela qual as XII tábuas introduziram a livre circulação de bens imóveis (idem, p. 84), inclusive como pressuposto necessário enquanto procedimento de limitação do solo para uso individual - para a apropriação definitiva da terra concedida aos patres familias via usus auctoritas (p. 91, nt. 96). O romanista ainda traça uma distinção entre um nexum facere preparatório e técnico e um nexum facere jurídico e ratificante: o primeiro é um procedimento levado a cabo por agrimensores segundo as exigências do negócio concreto, e o segundo é uma ratificação - já dentro do ritual da mancipatio, através de nuncupatio do adquirente - da mensuração realizada ad hoc ou mesmo de confins preexistentes. Assim, um solo possui a qualidade de «nexum esse» quando, tendo sido preparado tecnicamente, pode ser alienado pela mancipatio; este seria o sentido das passagens de Frontino e Gaio citadas (idem, pp. 95-96). Cf. também O. BEHRENDS, Les rapports entre la terminologie gromatique et celle de la jurisprudence classique, leurs points de contact et leur indépendence fondamentale: l'exemple de l'oeuvre de Frontin; structure, méthode, vocabulaire, in D. Conso - A. GonZALES, J.-Y. GUILLAUMIN (eds.), Les vocabulaires techniques des arpenteurs romains, Franche-Comté, 2005, pp. 201-217, especialmente pp. 210-211.

A teoria não deixa de ser interessante, além de definir questão intimamente conexa com a nossa pesquisa - embora trate-se de terreno pouco explorado, a começar pela ausência de críticas a essa nova concepção sobre o nexum facere. Não podemos, todavia, aceitá-la integralmente. Cremos que fosse possível a alienação de fundi no período decenviral (v. os argumentos adiante), e que fosse necessária uma definição dos confins do terreno antes de aliená-lo. Não havendo outro nome conservado pelas fontes, parece-nos provável que a alienação se fizesse pelo nexum, embora os detalhes a esse respeito não nos tenham sido transmitidos. A distinção entre um nexum facere em 
Repisemos que, segundo a opinião que julgamos mais adequada, a única forma de introduzir uma coisa na esfera in mancipio, no período decenviral, é apoderando-se fisicamente dela (mancipium facere, segundo a regra das XII tábuas, VI, 1). O ato de apreensão física, o poder de domínio e a própria coisa são o mesmo mancipium, ${ }^{421}$ e é em razão disso que P. NoAILLES negava a inclusão do fundus entre as res mancipi. ${ }^{422}$

Por esse motivo, no que diz respeito aos fundi na época decenviral, a não ser que se adote a teoria do nexum facere de BEHRENDS, a posição mais segura seria aparentemente a da sua inalienabilidade através de negócio «bilateral», restando como única forma de aquisição aquela prevista pela regra do usus auctoritas.

Nossa posição é entretanto intermediária: nem sufragamos na sua integralidade a ousada teoria do nexum facere tal como proposta por BEHRENDS, nem acreditamos na inalienabilidade dos fundi na época decenviral (a plena alienabilidade é o fim de um longo processo). Pensamos que o termo geral mancipatio da época posterior (já desvinculado do contexto original do mancipium), tantas vezes aplicado aos fundi e praedia, bem como o testemunho de Paul. Vat. 50 e a existência de uma arcaica actio de modo agri ${ }^{423}$ sejam fortes indícios de que um negócio formal -

sentido técnico e um nexum facere em sentido negocial é seguramente uma hipótese sem qualquer apoio nas fontes.

${ }^{421}$ P. NoAilles, Nexum cit., p. 216; C. W. Westrup, Notes sur la sponsio et le nexum... cit., p. 12; do mesmo autor, Introduction to early Roman Law II cit., p. 48; e Propriété primitive cit., p. 223 e ss. cf. também F. DE VISSCHER, Mancipium et res mancipi, in SDHI 2, pp. 285-286, cuja concepção entretanto é mais estreita (mancipium não como ato, mas como resultado do ato de apreensão). O mancipium contém, de qualquer forma, esse poder de comando do paterfamilias sobre todas as coisas que estão in mancipio, especialmente pessoas livres e escravos, que podem obedecer ao comando, embora as res móveis, por uma espécie de ficção, também fossem objeto dele. Impossível, entretanto, dar razão a F. DE VISSCHER, Mancipium et res mancipi cit., p. 293, quando inclui também os fundi na lista de coisas in mancipio.

422 Idem, p. 216, nt. 1.

423 As fontes diretas dessa ação são duas passagens de Paulo: i) Quaedam actiones si a reo infitientur, duplantur, velut... item de modo agri, cum a venditore emptor deceptus est (PS. 1, 19, 1); ii) Distracto fundo si quis de modo mentiatur, in duplo eius quod mentitus est officio iudicis aestimatione facta convenitur $(1,17,4)$. O que nos interessa aqui são dois pontos: a antigüidade dessa ação, que requer provas, e o fato seguro de que ela tinha como objeto uma nuncupatio realizada por ocasião de uma mancipatio fundi. Mais exatamente, ela envolve o vendedor de um fundus que, por ocasião da mancipatio declarou ter o terreno uma medida maior do que em realidade tinha; em razão disso, pela actio de modo agri, este responde diante do comprador pelo dobro do preço da venda. Não é difícil provar a sua antigüidade: Aggenus Urbicus, por exemplo, diz que os antiqui costumavam declarar, no 
provavelmente denominado nexum, mas cujo conteúdo não se pode precisar - fosse utilizado para esse fim.

Essa situação peculiar da propriedade fundiária (a saber, a desvinculação da idéia de mancipium) nos permite fazer uma distinção - válida para o período decenviral - entre o poder sobre os fundi e o poder sobre as pessoas livres e não livres da casa, além de animais e outras coisas.

Como vimos, uma fonte segura prova o uso arcaico da expressão fundus meus, enquanto, ao que tudo indica, a categoria dos fundi não era objeto de mancipium. Trata-se, portanto, de uma relação de «pertença» dissociada da idéia de manus/mancipium.

Tentaremos assim esclarecer, na seqüência, o que significava, após a aquisição da terra pelo usus, a possibilidade de se afirmar que a coisa era de alguém segundo o direito dos Quirites.

Sabe-se que, ao lado da expressão «meum est» dita simpliciter, está a afirmação «meum esse aio ex iure Quiritium», que é dita num contexto determinado. A cláusula ex iure Quiritium estava reservada a casos que mereciam uma especial proteção dos Quirites: a terra arável e limitada, os escravos e certos animais.

momento da venda de um terreno, a sua medida (Lachmann 14: Soliti erant antiqui in conductionibus et in emptiones modum comprehendere atque ita cavere, FVNDVM ILLVM, IVGERA TOT, IN SINGVLIS IVGERIBVS); o mesmo diz Frontino (Lachmann 13-14: De modo controversia est in agro adsignato. Agitur enim de antiquorum nominum propria defensione); Cícero é testemunha de um fragmento das XII tábuas $(\mathrm{VI}, 2)$ versando sobre uma nuncupatio a respeito dos vícios do prédio que o vendedor deveria declarar, sob pela de responder pelo duplum: Ac de iure quidem praediorum sanctum apud nos est iure civili, ut in iis vendendis vitia dicerentur, quae nota essent venditori. Nam cum ex duodecim tabulis satis esset ea praestari, quae essent lingua nuncupata, quae qui infitiatus est, dupli poenam subiret... Quidquid enim esset in praedio vitii, id statuerunt, si venditor sciret, nisi nominatim dictum esset, praestari oportere (de off. 3,65 ). Sobre a antigüidade da actio de modo agri, cf. M. VOIGT, Civil- und Criminalrecht... cit., p. 467-469, implicitamente; expressamente O. LENEL, Quellenforschungen in den Edictcommentaren, in SZ 3 (1882), pp. 190-191, «ein altciviles Rechtmittel aus einer lex mancipii»; A. PERNICE, Labeo... cit., p. 115, que crê não ser necessária uma nuncupatio específica. Conexa com a actio de modo agri é a controvérsia de modo agri, iniciada não só com base em um modus declarado numa venda, como também na simples pretensão de reestabelecimento do modus previsto na adsignatio original - que a nós interessa muito mais, como veremos adiante. Quanto à antigüidade da questão de modo agri em geral, M. WEBER, Die römische Agrargeschichte... cit., pp. 168-170, como veremos no próximo item, sustenta que ela surge no contexto das antigas comunidades agrárias. 
Através de uma importante passagem de Cícero, ${ }^{424}$ que evoca com detalhe o tempo das legis actiones, é possível vislumbrar as circunstâncias que envolviam essa afirmação.

No discurso em favor de Lúcio Licínio Murena, o orador, a fim de exaltar a ocupação do seu cliente sobre a do seu oponente S. Sulpício, que era jurisconsulto, procurou provar a superioridade da glória militar sobre a prática forense como caminho para o consulado. ${ }^{425}$

Cícero, a fim de diminuir a glória da ciência jurídica, relembra o tempo em que os jurisconsultos gozavam de grande prestígio, que era devido tão somente ao fato de que só eles sabiam o que se podia e o que não se podia legalmente fazer (ou que ações intentar), segundo um calendário que só eles conheciam; e em seguida narra o episódio em que Gn. Flávio lançou por terra a autoridade dos juristas ao revelar o calendário forense e compilar o direito pontifício, revelando-o aos leigos e assim possibilitando que estes prescindissem da sua consultoria. Os jurisconsultos, irados com esse episódio, reagiram instituindo o uso obrigatório de certas palavras (quaedam verba) que deveriam ser usadas nas ações, as quais exigiam novamente a sua assistência. ${ }^{426}$ Assim, Cícero provava que o prestígio dos juristas se reportava, não a um conhecimento nobre, mas a artifícios e astúcias.

A fim de ilustrar esses artifícios, Cícero narra como era um processo segundo as ações da lei. Em primeiro lugar, não se podia usar palavras comuns, como nesse exemplo de Cícero: "Fundus Sabinus meus est», seguido de uma razoável contestação por parte do réu: «Immo meus». Na ilustração de Cícero, o suposto proprietário de uma fazenda afirma diante do réu: «FUNDUS QUI EST IN AGRO QUI SABINUS VOCATUR», corretamente indicando o lugar e o nome, em seguida

\footnotetext{
${ }^{424}$ Pro Mur. 12, 26.

${ }^{425}$ Pro Mur. 9, 22.

${ }^{426}$ Pro Mur. 11, 25: Primim dignitas in tam tenui scientia non potest esse; res enim sunt parvae, prope in singulis litteris atque interpunctionibus verborum occupatae. Deinde, etiam si quid apud maiores nostros fuit in isto studio admirationis, id enuntiatis vestris mysteriis totum est contemptum et abiectum. Posset agi lege necne pauci quondam sciebant; fastos enim volgo non habebant. Erant in magna potentia qui consulebantur; a quibus etiam dies tamquam a Chaldaeis potebantur. Inventus est scriba quidam, Cn. Flavius, qui cornicum oculos confixerit et singulis diebus ediscendis fastos populo proposuerit et ab ipsis his cautis iuris consultis eorum sapientiam compilarit. Itaque irati illi, quod sunt veriti ne dierum ratione pervolgata et cognita sine sua opera lege agi posset, verba quaedam composuerunt ut omnibus in rebus ipsi interessent.
} 
invocando a proteção dos Quirites: «EUM EGO EX IURE QVIRITIUM MEUM ESSE AIO». E na seqüência chama o réu a juízo: «INDE IBI EGO TE EX IURE MANUM CONSERTUM VOCO», ao que o réu não sabia que responder, dado que não conhecia a fórmula. $E$ assim o mesmo jurisconsulto ${ }^{427}$ como que passava para o lado do réu, como fazem os flautistas, e dizia em seu lugar: "UNDE TU ME EX IVRE MANUM CONSERTUM VOCASTI, INDE IBI EGO TE REVOCO». E assim se iniciava o processo diante do pretor. ${ }^{428}$

Afora a crítica de Cícero a respeito do formalismo do antigo processo, ${ }^{429}$ temos um retrato fiel da afirmação que fazia o autor e das circunstâncias em que ela era feita e, o que é muito importante, uma prova do uso da legis actio tendo como objeto os fundi. ${ }^{430}$ Não se trata de uma afirmação gratuita de que alguém

${ }^{427} \mathrm{O}$ mesmo jurisconsulto ficava à disposição do autor, do réu e do pretor para que ninguém errasse as fórmulas. Cf. os comentários de A. BÜRGE, Die Juristenkomik in Ciceros Rede Pro Murena Übersezung und Kommentar, Zürich, Juris Druck, 1974, p. 116.

${ }^{428}$ Pro Mur. 12, 26: Cum hoc fieri bellissime posset: 'Fundus Sabinus meus est'. 'Immo meus', deinde iudicium, noluerunt. 'FUNDUS' inquit 'QUI EST IN AGRO QUI SABINUS VOCATVR'. Satis verbose; cedo quid postea? 'EUM EGO EX IURE QVIRITIUM MEUM ESSE AIO'. QUid tum? 'INDE IBI EGO TE EX IURE MANUM CONSERTUM VOCO'. Quid huic tam loquaciter litigioso responderet ille unde petebatur non habebat. Transit idem iuris consultus tibicinis Latini modo. 'UNDE TU ME' inquit 'EX IURE MANUM CONSERTUM VOCASTI, INDE IBI EGO TE REVOCO'.

${ }^{429}$ Cf. o comentário filológico a toda essa passagem por J. ADAMIETZ em Marcus Tullius Ciceros Pro Murena, Darmstadt, Wissenschaftlische Buchgesellschaft, 1989, pp. 132-142.

${ }_{430}$ Aparentemente, a exclusão arcaica dos fundi da categoria das res mancipi, como demonstramos acima, em virtude de uma incompatibilidade essencial entre os bens imóveis e o mancipium, também os excluiria como objetos da legis actio sacramento in rem. Mas não é assim. O próprio Gaio explica que, no caso dos fundi, era necessário levar em juízo uma porção de terra do fundus em questão: similiter si de fundo vel de aedibus sive de hereditate controversia erat, pars aliqua inde sumebatur et in ius adferebatur, et in eam partem proinde atque in totam rem praesentem fiebat vindicatio, velut ex fundo gleba sumebatur et ex aedibus tegula... (Gai. 4, 17). Essa possibilidade não entra em conflito com a impossibilidade de aquisição de um fundus por mancipium (é da natureza deste uma apreensão física da coisa, impossível no caso do solo). A própria fórmula da vindicatio não é incompatível com a ausência da apreensão (manu adprehendere), pois ela não inclui essa exigência no caso dos fundi; a não ser que se tratasse de coisa móvel, como o próprio Gaio o diz (Gai. 4, 16). Na passagem de Cícero, temos um retrato do direito arcaico; as fórmulas atinentes às legis actiones eram fixas, e portanto nos chegaram tal como eram, admitindo a disputa sobre bens imóveis. Em contraposição, não há nenhuma fonte referente ao período arcaico que faça referência ao fundus como objeto de mancipium. Do ponto de vista da doutrina, enquanto um grande número de autores, a exemplo dos citados acima a título de exemplo, defendem que os fundi não eram res mancipi, não temos conhecimento de nenhum autor que defenda a exclusão dos fundi como objetos da legis actio sacramento in rem. Podemos ainda recorrer a um importante estudo de H. LÉVY-BRUHL, Praedia absentia solent mancipari, in Studi Paoli (s/d), pp. 477-484, que esclarece essa questão. Ele lembra que, no ritual da mancipatio, temos a presença do pronome demonstrativo hunc (hominem); já na vindicatio fundi, não se diz hic fundus, querendo dizer que o terreno está presente, mas is fundus (Cic. pro Mur. 12, 26). Segundo o autor, a presença de uma parte do fundus, desde o início, já era suficiente para que se instaurasse o rito da vindicta-festuca no interior do sacramentum in rem. Quanto à possibilidade de alienação dos fundi por mancipatio, a presença da coisa (segundo o autor, essa exigência atendia a motivações mágicas) continuou sempre exigida quando esta fosse móvel, 
é proprietário, mas de uma invocação formal de uma relação de pertença ameaçada e que goza de uma proteção especial.

Ajunte-se a isso o fato de que o ius Quiritium nunca esteve ligado aos vínculos que seriam chamados posteriormente «obrigacionais»; a razão é que estes simplesmente não transcendem a esfera meramente pessoal, e portanto não exigem testemunho e proteção coletivos. ${ }^{431}$

Repare-se que essa invocação aparece nas fontes geralmente referida aos fundi e aos escravos, ${ }^{432}$ enquanto a afirmação meum est é de uso praticamente

por puro formalismo (p. 484), enquanto uma já antiga exceção permitia que os praedia absentia fossem alienados (p. 483). Isso não implica, na nossa opinião, que se pudesse aplicar aos fundi a idéia de mancipium no direito arcaico. Tratar-se-ia de uma exceção criada por motivos práticos, e que só seria comum numa época posterior, em que o comércio de terras tivesse se tornado algo corrente (o que é inimaginável no período decenviral, embora o comércio fosse já intenso).

${ }^{431}$ Nesse contexto são importantes as considerações de G. I. LUZZATTO, Le organizzazioni preciviche e lo stato, Modena, Premiata, 1948, pp. 12-15, e as de A. GUARINO, Ius Quiritium, in Le origini quiritarie - raccolta di scritti romanistici, Napoli, Jovene, 1973, pp. 174-176. Este último explica que as obrigações civis romanas não eram objeto do ius Quiritium pelo simples fato de não derivarem dele; isso também explica, como veremos na nota a seguir, a ausência nas fontes do uso da cláusula ex iure Quiritium no que diz respeito às relações obrigacionais. Basta citar duas fórmulas, a da legis actio sacramento in rem: «HANC EGO REM MEAM ESSE AIO EX IURE QVIRITIUM SECUNDUM SUAM CAUSAM», e a utilizada pelo autor da legis actio sacramento in personam: "AIO MIHI A TE FURTUM FACTUM ESSE PATERAE AUREAE, OB EAMQUE REM TE MIHI DAMNUM DECIDERE OPORTERE», que não faz qualquer menção ao direito quiritário. O autor acrescenta que - como nos parece provável -, no momento em que a obligatio se tornou uma instituição de direito romano, o direito quiritário teria já esgotado a sua função histórica (séc. VI a.C?), apesar do seu amplo uso nos tempos que viriam. É preciso contar - e isso dizemos nós - com uma certa abstração relativa das raízes históricas do ius Quiritium já no tempo decenviral. É preciso ter sempre em conta que o seu caráter arcaico (sua referência explícita ao testemunho e à proteção dos Quirites), bem como a sua origem certamente bélica já estão, não ausentes, mas enfraquecidos na mentalidade romana no tempo das XII tábuas.

${ }^{432}$ Referimo-nos às fontes da expressão meum esse aio ex iure Quiritium, e não à simples menção do ius Quiritium, que no campo da cidadania aparece em outras fontes; por exemplo, Gai. 1, 32-25; 3, 7273; Ulp. 3, 1-5. Também há exemplos de fragmentos em que aparece, genericamente, a cláusula ex iure Quiritium: Gai. 3, 167; Val. Prob. 6, 32. As fontes daquela expressão específica meum esse aio..., diretas ou indiretas, com indicação do seu objeto, são as seguintes: Cic. pro Mur. 12, 26 (fundus), Cic. in Verr. 2, 2, 31 (fundus); Gai. 1, 35, 9 (servus); 1, 35, 16 (servus); 1, 54, 2 (servus); 1, 54, 5 (servus); 1, 119 (homo); 1, 167, 5 (ancilla); 2, 24, 4 (homo); 2, 41, 3 (res); 2, 88, 2 (servus); 2, 194 (res); 2, 222 (res); 2, 267 (servus); 3, 56 (servus); 3, 80 (res?); 3, 167 (res?); 4, 16 (homo); 4, 34 (fundus); 4, 36 (res/homo); 4, 41 (homo); 4, 45 (res?); 4, 86 (res); 4, 93 (homo); Gall. de verb. ad ius civ. 12 (res/fundus). As fontes que se referem a fórmulas ou ao direito mais antigo só mencionam fundus e homo/servus. A genérica res aparece em referências que normalmente envolvem um elemento de direito próximo ao clássico, após a introdução da distinção entre coisas que são de alguém ex iure Quiritium e coisas que estão in bonis (Gai. 2, 41; 2, 222; 3, 80), ou então no contexto do processo formular (Gai. 4, 45; 4, 86). J. ZLINSZKY, Legis actio sacramento in rem, in SZ 106 (1989), p. 116, tem opinião semelhante, mas inclui também os animais de carga: «Die Machtposition, die der Staat durch seinen Beistand für den Einzelnen zuerst gesichert hat, war die Macht über die res mancipi, das heredium, die Sklaven und Zugtiere». Importa-nos essa idéia de proteção privilegiada a certos bens de 
universal, embora inicialmente, por razões intuitivas, se referisse apenas às coisas da vida diária, em geral móveis.

A razão é que, ao contrário do que ocorre com as coisas sobre as quais se exerce um domínio quase sempre físico, intuitivo e direto, e que foram adquiridas e se conservam nos estreitos limites da familia pecuniaque, os fundi, além da sua extensão, só se teriam tornado há pouco tempo, entre os romanos do período prédecenviral e decenviral, objeto de propriedade exclusiva. ${ }^{433}$ Deste modo demandam, como é razoável, uma especial proteção por parte da civitas em formação (dos Quirites), o que coloca a propriedade fundiária num patamar diferente. ${ }^{434-435}$

importância capital. Mas nossa opinião é que esse privilégio quiritário compreendia especialmente as terras assignadas exclusivamente num ager divisus et adsignatus e os escravos.

${ }^{433}$ Como vimos, os mores da ordem pré-cívica protegiam as possessiones sobre o solo gentílico e posteriormente sobre o ager publicus; não havia previsão, nesses antigos costumes, para a proteção de uma propriedade exclusiva. Nesse sentido, o ius Quiritium aparece como algo ligeiramente conflituoso com os mores, a proteger, no período pós-fundacional de Roma, a exclusividade da posse do ager privatus segundo a ordem das concessões dos reis e do populus.

${ }^{434}$ Pensamos também na cláusula de aquisição do direito quiritário como obtenção da cidadania: ius Quiritium adipiscunt, id est fiunt cives Romani (Gai. 1, 32b). Isso mostra que a afirmação de vinculação com o direito quiritário não é de caráter meramente real (de direito das coisas), ao menos na mentalidade clássica. L. MITTEIS, Römisches Privatrecht I cit., p. 66, define o próprio direito quiritário como «auf die römische Bürgschaft beschränkte Recht». M. KASER, Das altrömische lus cit., p. 77, opina todavia que os objetos originais do ius Quiritium, quais sejam, a propriedade, a liberdade e o poder familiar, não faziam qualquer referência à idéia de cidadania. Contra essa idéia, F. DE VISSCHER, Ius Quiritium, civitas romana et nationalité moderne, in Studi Paoli (s/d), p. 240, diz que a expressão ius Quiritium expressa uma pertença ao populus Romanus, em oposição aos Latini. Pensamos que não se trata de uma cidadania em sentido clássico, abstrato; como bem o explica P. CATALANo, Populus Romanus Quirites, Torino, G. Giappichelli, 1974, pp. 146, ius Quiritium e civitas Romana têm uma grande semelhança, mas histórias diferentes: a primeira é mais antiga e responde a uma concessão concreta do populus, na qual prevalece o aspecto concreto da pluralidade dos Quirites; a segunda aponta para uma abstração da idéia de populus.

${ }^{435}$ Esse patamar diferente se explica particularmente pela dificuldade prática de se comprovar a propriedade imobiliária (a favor dessa afirmação fala a velha tradição da prova da propriedade como probatio diabolica). Uma coisa móvel, como sempre foi na tradição jurídica ocidental, e como é praticamente natural, pertence a princípio àquele que a detém. Já uma fazenda, um terreno extenso, mesmo quando intimamente ligado à família (como o é caso do heredium ampliado pelo trabalho), requer um testemunho, uma autoridade que comprove essa relação de «pertencialidade» («Zugehörigkeit») e a faça prevalecer sobre uma afirmação contrária ou contraposta; uma das soluções é o cadastro imobiliário que Numa teria instituído; na falta dele, quem faz parte da civitas pode recorrer ao testemunho da comunidade dos Quirites, que em última instância garantem que a terra continue nas mãos do seu «proprietário», também porque, como elementos do Populus Romanus Quirites, em seu nome foi feita a concessão da terra originalmente conquistada e tomada das mãos dos inimigos, no contexto desse processo de privatização do solo romano a que assistimos nos séculos VII-V a.C. 
Sua origem é, além disso, uma concessão do soberano: ${ }^{436}$ eram quase sempre conquistas de guerra que foram distribuídas irrevocavelmente aos patres familias. Cabe assim aos Quirites proteger cada um dos seus membros e garantir o cumprimento das atribuições que eles mesmos fizeram em nome do populus Romanus Quirites. ${ }^{437} \mathrm{~A}$ «propriedade» exclusiva de um pater é nada menos que uma forma de participação no poder dos Quirites, ${ }^{438}$ fato que se confirma com a teoria do modus agri de M. WEBER que estudaremos mais tarde, e com a idéia conexa de fundus como Genossenrecht, que forma o substrato jurídico e ideal do terreno concretamente delimitado (o fundus objeto de usus).

Dizer que um fundus é alicuius ex iure Quiritium constitui, em primeiro lugar, a invocação de um testemunho: cada um dos Quirites ${ }^{439}$ poderia confirmar que a coisa pertence ao cidadão que o invocou, pressuposta a verdade da sua afirmação. ${ }^{440} \mathrm{O}$ direito arcaico tem esse caráter quase pessoal, apesar do formalismo, e que aparece explicitamente na fórmula do testamentum per aes et

\footnotetext{
${ }^{436}$ «Was vom Staate kommt, soll aber durch den Staat gesichert werden» (J. ZLINSZKY, Legis actio sacramento in rem cit., p. 116). Mesmo que a terra tenha sido adquirida de outro pater pelo usus, a sua origem continua sendo a antiga concessão.

${ }^{437} \mathrm{O}$ que faz pensar no antigo adágio suum cuique tribuere. Uma profunda idéia de justiça animava os romanos desde as origens; de outro modo não se poderia justificar o grande desenvolvimento do direito romano.

${ }^{438}$ P. CatAlano, Populus Romanus Quirites cit., p. 153, nt. 45.

439 Os Quirites são os chefes das famílias, cidadãos armados («Wehrmänner», cf. KRETSCHMER, Lat. quirites und quiritare, in Glotta 10 (1920), p. 148; Suet. Div. lul. 70: Quirites eos pro militibus appellaret) e membros do populus; cada gens é formada por dez dessas famílias, e a reunião das gentes resulta na totalidade da sociedade romana, mesmo pré-romana. A significação de Quirites, ium como um substantivo comum referente aos homens reunidos em assembléia é confirmada pela pesquisa filológica - cf. bibliografia em L. LABRUNA, Quirites, in Labeo 8 (1962), p. 345, nt. 40, e também A. WALDE, J. B. HofMANN, Lateinisches etymologisches Wörterbuch cit., p. 409, v. Quirites, que sustenta a procedência de *co-uiriom - do lat. arc. uir, homem, soldado, através da raiz *uiriti e do plural virites (Gell. 13, 23: Virites Quirini) - «Gesamtheit der Bürgerschaft», como *co-uiria forma cūria, seguindo o mencionado KRETSCHMER. O singular quiris é atestado por Fest. 254: illius quiris laeto datus. O próprio L. LABRUNA, Quirites cit., pp. 349-348, conclui que os Quirites eram cada um dos cidadãos que faziam parte da comunidade romana primitiva, resultado da fusão dos elementos sabino e latino.

O poder dos Quirites não constitui uma oposição à civitas em formação: trata-se de um desenvolvimento paralelo da autonomia dos patres e da força organizativa da comunidade como um todo (futuramente um Estado, embora evidentemente não em sentido moderno, conforme os pressupostos metodológicos fixados por A. ALFÖLDI, Römische Frühgeschichte - Kritik und Forschung seit 1964, Heidelberg, C. Winter, 1976, p. 42-43), como ressalta o mesmo A. ALFöLDI, Zur Struktur des Römerstaates im 5. Jahrhundert v. Chr., in O. REVERDIN (publ.), Entretiens sur l'antiquité classique XIII - Les origines de la République romaine, Genève, Vandoevres, 1966, p. 232, seguindo uma teoria de DE SANCTIS.

${ }^{440}$ A. MAGDELAIN, De la royauté et du droit... cit., p. 83.
} 
libram conservada por Gaio: "HAEC ITA VT IN TABVLIS CERISQVE SCRIPTA SVNT, ITA DO ITA LEGO ITA TESTOR, ITAQVE VOS, QVIRITES, TESTIMONIUM MIHI PERHIBETOTE». ${ }^{441}$

No caso do testamento, tratava-se de testemunhas formalmente presentes. Já no caso do usus fundi, bastava recorrer a qualquer um que tivesse conhecimento da situação fática da posse; ${ }^{442}$ mas o testemunho no seu aspecto de autoridade, ínsito na afirmação do meum esse, pressupõe imediatamente que, sendo os fatos a favor do autor (esse é um problema secundário a ser solucionado em juízo, de acordo com o direito probatório), os Quirites garantirão essa situação. ${ }^{443}$

Uma comparação entre a fórmula do antigo testamento e a cláusula do meum esse permite visualizar esses dois elementos: o do ato individual realizado e o da sua garantia ou confirmação quiritária, de caráter coletivo. ${ }^{444}$ No testamentum per aes et libram, o testador diz «ITA DO ITA LEGO ITA TESTOR», ou seja, que ele deseja realizar o testamento e assim o faz; a invocação da testemunha dos Quirites adquire então o caráter de confirmação atual: «ITAQUE VOS, QVIRITES, TESTIMONIUM MIHI PERHIBETOTE», ou seja, os Quirites são a prova absoluta de que tudo está sendo feito de acordo com o direito.

No testamento, o ato realizado e a confirmação são portanto imediatos. No caso da afirmação meum esse aio, o ato realizado não é pontual, mas de

${ }^{441}$ Gai. 2, 104. A invocação aos Quirites também aparece, para citar dois exemplos, na formula devotionis (Liv. 5, 41, 3: Sunt qui M. Folio pontifice maximo praefante carmen devovisse eos se pro patria Quiritibusque Romanis tradant; a longa fórmula está em 8, 9, 6-7) e na formula censoria (Varr. se ling. lat. 6, 86, 6: omnes Quirites, pedites armatos privatosque).

${ }_{442}$ A. MAgdelain, De la royauté et du droit... cit., p. 83.

${ }^{443}$ Podemos imaginar um tempo em que a afirmação de propriedade, o simples meum esse, como já acenávamos, sem qualquer referência à proteção de um proto-Estado, pudesse contar apenas com os parentes e amigos do interessado, além da sua própria força (autotutela) - como em alguns casos continua sendo no período decenviral, a exemplo da repressão imediata ao furto: «SI NOX FURTUM FAXIT SI IM OCCIDIT IURE CAESUS ESTO». Para uma exposição histórico-arqueológica sobre essa situação no período do surgimento da civitas e da cidade, cf. C. AMPOLO, Die endgültige Stadtwerdung Roms im 7. und 6. Jh. v. Chr. - Wann entstand die civitas?, in D. PAPENFUSS - V. M. STROCKA (org.), Palast und Hütte - Beiträge zum Bauen und Wohnen im Altertum von Archäologen, Vor- und Frühgeschichtlern, Mainz am Rhein, P. von Zabern, 1982, pp. 319-324; e também D. RIDGWAY - F. R. RIDGWAY (ed.), Italy Before the Romans... cit., pp. 15-16. Os romanos souberam empregar racionalmente todos os meios para instituir uma ordem jurídica, para desenvolver a função ordenadora e construtiva, a juridicidade; a ordem dos Quirites é um rompimento, e ao mesmo tempo uma recriação de elementos que já existiam em outros povos (P. DE FRANCISCI, Arcana Imperii III, t. 1, Milano, Giuffrè, 1948, p. 4; cf. J. ZLINSZKY, Legis actio sacramento in rem cit., p. 109, esp. nt. 13-15 para bibliografia e para uma exposição dessa idéia).

${ }^{444}$ Coletivo na medida em que se refere ao corpo dos Quirites, mas não em sentido abstrato: a referência é concreta, a cada um dos Quirites. 
natureza contínua (a coisa já era alicuius, e continua sendo); a confirmação «EX IURE QVIRITIUM», segundo o direito quiritário, é também contínua, embora possa ser provada em juízo caso contestada (ou seja, no futuro). Conquanto haja uma diferença quanto à atualidade dos atos de testar e afirmar a propriedade, os mesmos elementos estão presentes: o fato individual e a sua confirmação jurídica, com validade geral (erga omnes, mas no sentido concreto de eficácia assegurada pelos Quirites).

Essa dualidade também aparece numa passagem de Cícero que, pensamos, é muito importante para a nossa teoria sobre a auctoritas, e que examinaremos por isso com mais detalhe adiante: Fundus a patre relinqui potest, at usucapio fundi, hoc est finis sollicitudinis ac periculum litium, non a patre relinquitur, sed a legibus. ${ }^{445}$ Lendo a passagem numa "chave arcaica» - já que ela faz referência a uma característica já presente no direito arcaico -, é impossível não ver os mesmos dois elementos: o fundus é deixado pelo pai, mas a aquisição do fundus concreto, a sua exclusividade e indiscutibilidade como meum esse não é «deixada», não é garantida pelo ancestral (pelo ato «privado»), mas pelo direito, ou seja, pelo ius Quiritium - que no caso reconhece a adsignatio original dentro do sistema de limitação, como veremos. A transmissão (a patre relinqui) é o fato privado; a atribuição definitiva do meum esse segundo o direito (a legibus relinqui) é a garantia dos Quirites. ${ }^{446}$

Eis, portanto, o significado da cláusula fundus meum esse aio ex iure Quiritium: "afirmo que o fundus é meu segundo o direito e o testemunho dos Quirites». ${ }^{447}$

\footnotetext{
${ }^{445}$ Pro Caec. 74, 14-16.

${ }^{446}$ Não se pode cair no erro de julgar esse raciocínio como algo abstrato e portanto inaplicável ao direito arcaico. Embora na prática sejam indissociáveis, podemos separar o plano das afirmações privadas e o plano da garantia quiritária, conferida aos cidadãos pelo corpo dos Quirites.

447 Segundo G. BESELER, SZ 49 (1929), p. 435, inicialmente ex iure Quiritium queria dizer «wie es aus der Gerichtsstätte der Quiriten kommt», uma referência explícita ao tribunal onde a questão era julgada; mais tarde apenas teria a expressão ganhado o significado derivado de «segundo o direito dos Quirites». Certamente é antiga a aplicação do termo ius ao lugar de administração da justiça (W. KUNKEL/T. MAYER-MALY, Römisches Privatrecht cit., p. 50).Temos a opôr apenas o fato de que quase sempre a atribuição do meum esse procedia não de um ius dicere, mas, por exemplo, da divisão de despojos de guerra ou de uma concessão do populus. A questão poderia, na pior das hipóteses, vir a
} 
O fundamento dessa relação de pertença é o próprio ius Quiritium. De qualquer modo, a lei das XII tábuas só vieram confirmar o que já era um costume, mesmo relativamente recente, entre os romanos. ${ }^{448}$

\author{
Pensamos portanto que esse ius ${ }^{449}$ relativo aos fundi não surgiu por
} imposição legal, mas sim naturalmente, ${ }^{450}$ como nos revela Pompônio, embora na

ser objeto de uma legis actio diante de um tribunal, in iure, mas esse é um fato acidental e muitas vezes tido apenas como uma possibilidade.

${ }^{448}$ R. OREstANO, Dal ius al fas cit., p. 268, observa, expressando a opinião geral, que as XII tábuas tiveram apenas a função de fixar um direito que já existia, e não de criá-lo.

${ }^{449} \mathrm{O}$ meum esse constitui um ius por fundar-se no direito dos Quirites. A definição de ius que parece mais adequada para o período decenviral é a de uma autorização de origem divina cuja violação, todavia, não torna alguém sacer (em oposição ao fas, que é capaz de fazê-lo), segundo a tese mais aceita, esposada, entre outros, por M. KASER, Das altrömische lus... cit., p. 28-29. Ius qualifica uma ação como permitida, uma vez que o poder de praticá-la foi aprovado, com a ajuda divina; por isso a decisão do magistrado é um ius dictum, a condenação um iure iudicatus, e por isso quem reivindica justamente pode dizer ius feci (idem, p. 28; esse significado se contrapõe àquele presente nas expressões in ius vocare, in ius ducere, in iure cedere; v. nota anterior). Isso indica que deve ter havido uma razão também religiosa - não só econômica - para o estabelecimento de um ius sobre os fundi através do usus (a atribuição do alicuius esse). Segundo a etimologia mais aceita, ius (ious) procede do védico yós (esp. no Ŗg Veda), vocábulo indeclinável e ausente no sânscrito clássico, e que significa "saúde», do qual se deriva a idéia de «limpo através de ritual» (yaozda, yaozdodāiti) (v. bibliografia em R. ORESTANO, Dal ius al fas, in BIDR 46 (1939), p. 218, nt. 53; M. MONIER-WILLIAMS, $A$ Sanskrit-English dictionary... cit., p. 859). O fato é que iustus, mesmo tardiamente, ainda significa conformidade com a vontade divina em razão da correta performance dos ritos: iusta facere, iusta dies, iusta ludorum, iustum bellum (cf. em geral W. W. BUCKLAND, Ritual Acts and Words in Roman Law, in Festschrift Koschaker I, pp. 16-26; há uma hipótese que restringe o ius ao facere, a atos sem manifestação verbal - como no ius feci sicut vindictam imposui em Gai. 4, 12 -, em oposição ao fas, que se reportaria ao dicere ou tacere, conforme Prisc. Gramm. 3, 486; cf. R. ORESTANO, Dal ius al fas cit., p. 261).

Um significado semelhante, talvez mais concreto, é dado por F. WIEACKER, lus e lex in Roma arcaica, in Scritti Guarino 7, pp. 3109-3110. Ele assinala que a função do ius é atribuir a alguém, num certo contexto (um ato ou uma situação), através de ritos tradicionais, a senhoria jurídica sobre pessoas ou coisas; opõe-se a ele a vis, a força contrária ao direito. Essa senhoria tem a característica de ser absoluta, com validade geral.

${ }^{450}$ Não como imposição «da natureza humana», mas em razão das circunstâncias, de fatos contingentes. Compare-se com essa passagem de Cic. pro Sest. 42, 91: Quis enim vestrum, iudices, ignorat ita naturam rerum tulisse ut quodam tempore homines nondum neque naturali neque civili iure descripto fusi per agros ac dispersi vagarentur, tantumque haberent quantum manu ac viribus per caedem ac vulnera aut eripere aut retinere possunt? Qui igitur primi virtute et consilio praestanti exstiterunt, ii perspecto genere humanae docilitatis atque ingenii dissipatos unum in locum congregarunt eosque ex feritate illa ad iustitiam atque ad mansuetudinem transduxerunt. Tum res ad communem utilitatem, quas publicas appellamus, tum conventicula hominum, quae postea civitates nominatae sunt, tum domicilia coniuncta, quas urbes dicimus, invento et divino iure et humano moenibus saepserunt. Cf. o comentário de O. BEHRENDS, Die Gewohnheit des Rechts und das Gewohnheitsrecht - Die gestigen Grundlagen des klassischen römischen Rechts mit einem vergleichenden Blick auf die Gewohnheitsrechtslehre der Historischen Rechtsschule und der Gegenwart, in D. WILLOWEIT (org.), Die Begründung des Rechts als historisches Problem, München, R. Oldenbourg, 2000, p. 53, nt. 82. Observa ainda R. ORESTANO, Dal ius al fas cit., p. 266, que o direito romano arcaico formou-se através de cristalizações consuetudinárias, e não repentinamente, como que provindo diretamente da divindade. As normas costumeiras, através da atividade dos pontífices - 
sua base esteja uma adsignatio em terreno objeto de limitatio. A necessidade de que a terra fosse cultivada de modo estável a partir dos heredia concedidos às famílias ${ }^{451}$ levou o corpo cívico a assegurar que a terra permanecesse nas mãos de quem efetivamente tivesse capacidade de usufruí-la.

Repare-se, entretanto, que esse alicuius esse garantido juridicamente não define, por si, a natureza peculiar da relação que o paterfamilias tem com a coisa; ${ }^{452}$ não se pode falar em propriedade em sentido abstrato. No caso dos escravos, essa relação é de mancipium. Esse não é o caso dos fundi.

A natureza peculiar do meum esse relativo aos fundi é, com efeito, a de uma relação de pertença dependente da proteção e da confirmação dos Quirites, incluindo especialmente a garantia sobre a adsignatio original do terreno e o modus respectivo. Veremos mais adiante que se trata de uma generalização do antigo direito fundado sobre a auctoritas do soberano da colônia, o responsável pelas assignações no contexto do antigo sistema de delimitação romano, que data de época pré-decenviral. Entrevemos, aí, a autonomização do direito civil com relação às concessões de terra reais e republicanas.

\footnotetext{
em contato com a divindade - e da prática do dia-a-dia, eram vistas como um conjunto de prescrições, mas a sua confirmação divina se manifestaria nos casos concretos (sem um caráter imutável, fixo, como se fossem normas diretamente reveladas). Cf. F. ScHULZ, Prinzipien des römischen Rechts, 1934, p. 4; sobre o estilo das leis romanas desde os primórdios, H. HONSELL, Der Gesetzesstil in der römischen Antike, in Scritti Guarino 4, pp. 1659-1673; P. FREZZA, Preistoria e storia della lex publica, in Apx

${ }^{451}$ Seguindo a tese dominante que postula uma original propriedade comum sobre a terra, com exceção do heredium - como anteriormente explicamos -, é de se concluir necessariamente que a propriedade exclusiva sobre partes mais extensas de terra (os fundi, que incluíam o heredium) teria sido conquistada aos poucos pelo usus, já que esta é a única regra expressamente prevista para a sua aquisição exclusiva. Cf. F. WIEACKER, SZ 89 (1972), p. 416, bem como o objeto da sua recensão, G. DIósDI, Ownership in Ancient and Preclassical Roman Law cit., p. 35.

452 Embora seja perfeitamente adequado caracterizar o meum esse, sendo um ius, como «signoria giuridica di un paterfamilias» (F. WIEACKER, lus e lex in Roma arcaica cit., p. 3108).
} 


\subsection{A antiga ordem augural de delimitação do solo (limitatio). A figura do auctor divisionis et adsignationis e seu antecessor arcaico}

Vimos de forma um tanto genérica, nos dois itens anteriores, que o heredium concedido aos cidadãos desde os inícios do período régio ${ }^{453}$ foi sendo gradualmente expandido pelo cultivo dos patri familias. Estes exercitavam, com efeito, o usus sobre certa parcela de um solo delimitado ao redor do heredium como veremos, regra geral em centúrias -, e essa aquisição passou a ser gradualmente reconhecida e garantida pelo direito quiritário (no período decenviral pela regra do usus auctoritas), constituindo um modo concreto de participação na comunidade dos Quirites (um dos significados arcaicos de fundus). ${ }^{454}$

Se queremos encontrar um antecedente imediato para a regra do usus auctoritas, algo necessário para entendê-la, sabendo (i) que ela diz respeito à

453 Uma nota importante sobre a questão cronológica. Não nos parece possível sustentar, a não ser como hipótese, uma origem muito recuada no tempo para o esquema que expomos neste item, segundo o qual a propriedade proveniente das assignações, especialmente no contexto da centuriatio e do antigo sistema de limitação, estava baseada na auctoritas de um soberano. Hipoteticamente esse esquema recuaria aos primeiros tempos de Roma, ao início da Monarquia no séc. VIII (essa é a ousada posição de BEHRENDS), e entraria em decadência no séc. V, com a edição da lei das XII tábuas. Mas não temos fontes seguras sobre os inícios do período régio, e é por demais perigoso tomar literalmente a tradição dos bina iugera distribuídos por Rômulo, ligando-a diretamente à centuriatio. Outro argumento decisivo é que, por mais arcaico que seja o sistema augural (que pode ter sua origem em tempos pré-cívicos), ele pressupõe, no que diz respeito à sua aplicação às distribuições de terra, uma mínima estrutura "estatal», augures, agrimensores, magistrados, bem como técnicas relativamente complexas de mensuração. Podemos afirmar com segurança, entretanto, que, como já nos inícios da República a distribuição de terras e a formação de colônias era uma prática constante, embora em desenvolvimento (seria anti-histórico negá-lo), já estavam presentes, há algum tempo, as condições para que um tal esquema estivesse em funcionamento.

Parece-nos conveniente, portanto, considerar a fase final da Monarquia e os inícios da República como ponto de partida seguro para o esquema que propomos a respeito dos inícios da propriedade e da concessão do usus ex auctoritate. Nossa referência aos inícios do período régio, portanto, deve ser tomado como hipótese.

${ }^{454}$ M. WEBER, Die römische Agrargeschichte cit., p. 171-174. 
"aquisição» dos fundi e (ii) que estes surgem e se desenvolvem a partir de um antigo sistema de delimitação e parcelamento de terrenos segundo um modus agri anterior às XII tábuas, precisamos esclarecer, antes de mais nada, como esse sistema funcionava e, a seguir, tirar as conseqüências pertinentes.

Os romanos fazem, é verdade, referência a um período mítico durante o qual os campos não estavam divididos e atribuídos a particulares (divisi et adsignati), e portanto não tinham dono; mas a história da propriedade fundiária romana se inicia justamente com a divisão ideal e a demarcação do solo. ${ }^{455}$

A finalidade prática dessa delimitação, desde tempos muito antigos que o arqueólogo contemporâneo A. CARANDINI faz recuar até os tempos míticos de Alba,$-{ }^{456}$ era o controle estável da terra. Ela surge da necessidade das grandes famílias dedicadas à arboricultura de dispôr de confins certos, ou seja, assinalados por pedras terminais reconhecidas pela comunidade e consideradas inamovíveis.

\footnotetext{
${ }^{455}$ Virgílio assinalava que, antes da era de Júpiter, ne signare quidem aut partiri limite campum fas erat (Georg. 1, 126-127), e que nulli subigebant arva coloni, ou seja, que não havia propriedade privada nem uso do solo (cf. M. ERREN, P. Vergilius Maro, Georgica II - Kommentar, Heidelberg, Universität, 2003, p. 91). Claudian. in Ruf. 1, 381 e ss., ilustra a mesma situação: Tum tellus communis erit, tum limite nullo / discernetur ager; nec vomere sulcus adunco / findetur: subitis messor gaudebit aristis. Isso é indício, não de uma espécie de comunismo, mas de uma ordem jurídica em que a relação entre os homens e a terra tinha, num passado remoto, uma natureza diferente. Como veremos na seqüência a propósito de uma passagem de Sérvio, essa tradição mítica está em conflito com a história: não se trata de uma Idade de Ouro, mas de um tempo em que reinava o nomadismo e a ausência de uma ordem jurídica. A informação importante que se extrai desses mitos é, entretanto, a profunda e inevitável relação entre a presença dos marcos e a vigência de um regime de uso exclusivo dos campos; em uma formulação mais teórica, a pressuposição, para a existência da propriedade privada sobre o solo, da existência de confins exteriores. Isso prova a persistência, no espírito dos romanos, da idéia de que a propriedade é algo concreto e visível, um terreno assinalado por marcos e limites naturais, e não um conceito jurídico abstrato. Assim, a aquisição de um terreno ou lote, para o direito arcaico, é a aquisição de um espaço demarcado, não-conflituoso, cuja exclusividade e intangibilidade é garantida pela comunidade (pelos Quirites) e tutelada pela religião romana, com sanções desde o início muito severas.

${ }^{456}$ La nascita di Roma - Dèi, Lari, eroi e uomini all'alba di uma civiltà, Torino, G. Einaudi, 1997, p. 189. A tradição que atribui a Fauno ou a Silvano (Ex lib. Dolab. in Lachmann 302: Silvanus... primus in terram lapidem finalem posuit) a instituição dos marcos ou pedras terminais é uma divergência daquela outra testemunhada por Virg. Georg. 1, 125, que a atribui a Júpiter (Terminus?), confirmada com uma passagem de um antigo livro gromático: cum autem luppiter terram Aetruriae sibi vindicavit, constituit iussitque metiri campos signarique agros (liber Vegoiae in Lachmann 350). Esta última versão é a mais comumente encontrada nos escritores latinos. Associa-se Silvano mais naturalmente à instituição das plantações (Serv. in Virg. En. 1, 20; CIL III 3498: SILVANUS HERBARIUS; CIL XII 103: HORTULI CUSTOS).
} 
Esses limites teriam sido, em tempos pré-romanos, a primeira forma de direito e de soberania, uma primeira forma de «posse» territorial por parte das famílias. ${ }^{457}$

O fato é que a delimitação ostensiva dos terrenos, para os romanos e outros povos antigos, ${ }^{458}$ aparece como a origem concreta da propriedade no sentido de senhorio corpóreo sobre um território, seja em âmbito privado, seja público. ${ }^{459} \mathrm{Um}$ escritor latino chega a afirmar que a divisão dos campos constituiu a própria origem dos direitos: ex agrorum divisione nata sunt iura. ${ }^{460}$

Historicamente, a divisão do solo romano como um todo, desde o período "fundacional», era realizada através da determinação de medidas ideais (como veremos mais tarde) e fronteiras exteriores e interiores. As fronteiras mais exteriores separavam o território romano dos territórios estrangeiros; as interiores dividiam entre si as tribos e outras regiões comuns, mas também traçavam os limites entre vizinhos cujas terras eram, como veremos, objeto propriedade exclusiva ou de mero usus dependente da auctoritas do fundador da colônia, ao menos a partir do fim da Monarquia. ${ }^{461}$

Deste modo, as fronteiras públicas (limes) definem o território «estatal» denominado ager e regiões comunitárias, os territorii ${ }^{462}$ e as regiones. As fronteiras privadas traçarão, mais tarde, os limites convencionais entre os fundi e suas subdivisões (loci). ${ }^{463}$

${ }^{457}$ Idem, pp. 189-192. No mesmo sentido, H. WAGENVOORT, Roman Dynamism cit., p. 82: «Only if we try to picture a community without anything resembling a land registry can we realize the significance of boundary marks for ancient society».

${ }^{458} \mathrm{O}$ exemplo por excelência é a Babilônia no tempo dos Cassitas. Conforme o estudo de F. X. STEINMETZER, Über den Grundbesitz in Babylonien zur Kassitenzeit - Nach den sog. Grenzstein dargestellt, Leipzig, Heinrich, 1918, p. 10, a propriedade privada se introduz com a instituição dos marcos de pedra ("Grenzsteine») ou kudurru.

459 Cf. as fontes epigráficas sobre a delimitação do território romano relacionadas por A. VON DOMASZEWSKI, Abhandlungen zur römischen Religion, Leipzig-Berlin, 1909, pp. 71-72.

${ }^{460}$ Serv. In Virg. En. 4, 58. O contexto de Sérvio é muito mais histórico do que mítico: os antigos - cf. a cosmovisão grega em Mosch. trag. frag. 6, 9, dos tempos pastoris à agricultura - teriam sido povos nômades e sem lei (homines [qui] sine lege vagabantur); com o uso da agricultura e a demarcação dos campos, o direito teria surgido naturalmente. Cf. Tib. 1, 3, 43-44: non domus ulla fores habuit, non fixus in agris / qui regeret certis finibus arva lapis.

${ }^{461}$ A. RudORFF, Grommatische Institutionen, in F. BLUME - K. LACHMANn - A. RudorfF (org.), Die Schriften der römischen Feldmesser II, Berlin, G. Reimer, 1852, p. 234.

${ }^{462}$ Pomp. ench., D. 50, 16, 239, 8: 'Territorium' est universitas agrorum intra fines cuiusque civitatis.

${ }^{463}$ Idem, p. 235. Repare-se que as demarcações privadas, inicialmente, não possuem reconhecimento jurídico diante do antigo sistema augural de limitação. Mais tarde elas prevalecerão e inclusive levarão ao esquecimento das antigas divisões do solo. 


\section{Estas últimas são exteriorizadas principalmente pelos marcos}

(termini). ${ }^{464}$ A terminatio (verbo terminare) é o termo técnico - provavelmente utilizado tardiamente - para a externalização de fronteiras ideais ou medidas de terra (modus agri) através da colocação de marcos de pedra (termini, cippi, lapides) ou estacas (pali, stipites). ${ }^{465}$ Já no período arcaico, ${ }^{466}$ os limites (fines) de um terreno privado - os limites do suum - eram externalizados por marcos (termini em sentido estrito) $)^{467}$ consagrados a Júpiter Terminalis (de 'Opíou $\Delta$ iòs) ${ }^{468-469}$ no contexto de um culto com rito próprio e de natureza privada. ${ }^{470}$

${ }^{464}$ Pode-se confundir os limites em sentido ideal, que são entes imateriais, com a sua exteriorização física, os marcos - embora metafisicamente não se possa dizer qual desses entes possui prioridade (uma concepção idealista tenderia a dar prioridade aos limites ideais, enquanto um realista preferiria ressaltar os marcos). Em alemão, por exemplo, a palavra «Mark» designa, segundo o seu significado mais antigo, o sinal demarcatório e a própria fronteira em sentido ideal. Parece-nos que a palavra portuguesa «marco» não permite essa confusão.

${ }^{465}$ E. FABRICIUS, v. terminatio, in RE 9, p. 779. O vocábulo masculino terminus desenvolve-se, segundo P. KRETSCHMER, Dyaus, Zeus, Diespiter und die Abstrakta im Indogermanischen, in Glotta 13

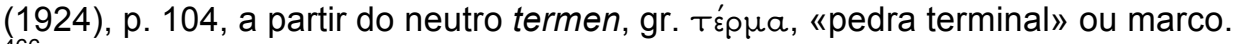

${ }^{666}$ Com forte probabilidade, a terminatio existia antes do reinado de Numa Pompílio; este apenas a tornou obrigatória, como afirma E. PeruzzI, Origini di Roma II - Le lettere, Bologna, Pàtron, 1973, p. 147. Ele cita o caso do ager arcifinius, terreno originalmente não limitado e cuja memória, entre os romanos, está ligada a um passado remoto (Frontin. De agr. qual. in Lachmann 5-6).

467 «Termini dicti quod terrae mensuras distinguunt atque declarant. His enim testimonia finium intelleguntur, et agro intentio et certamen aufertur» (Isid. etym. 15, 14, 3). Há um exemplo tardio de uma terminatio em CIL $1^{2} 584$, a Sententia Minuciorum de 117 a.C., que traz a seguinte expressão: EOS FINEIS FACERE TERMINOSQUE STATVI IVSERUNT, e menciona detalhadamente as pedras divisórias (por exemplo nas linhas 13-23, que descrevem o iugo recto, uma linha reta de marco a marco). V. também CIL III 2827; e III 586 e 12306. O Digesto faz muitas referências aos termini e ao verbo terminare: Herm. 1 epit., D. 1, 1, 5 pr; Ulp. 2 ad Ed., D. 1, 12, 3 pr; Scaev. 2 dig., D. 4, 8, 44 pr; Paul. 23 ad Ed., D. 10, 1, 4, 5; Ulp. 6 opin., D. 10, 1, 8 pr; Paul. 3 resp., D. 10, 1, 12 pr; Modest. 5 resp., D. 19, 1, 39 pr; Call. 2 inst., D. 41, 1, 12 pr; Paul. 54 ad Ed., D. 41, 2, 3, 2; Mod. 8 reg., D. 47, 21, 1 pr; Call. 3 cogn., D. 47, 21, 2 pr; Call. 5 cogn., D. 47, 21, 3 pr.

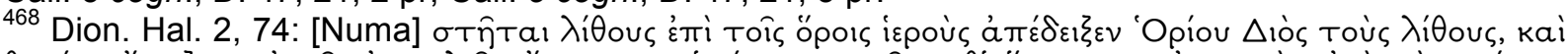

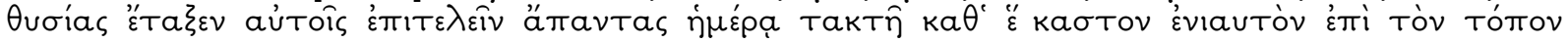

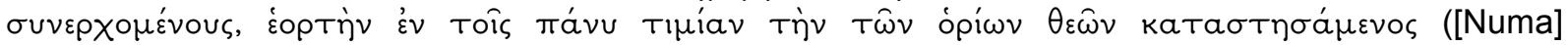
consagrou essas pedras a Júpiter Terminus e ordenou que todos deveriam se reunir no local anualmente num dia determinado e oferecer sacrifícios; e ele fez desse festival em honra desses deuses dos confins o mais digno de todos).

${ }^{469}$ CIL XI 351: IOV[I] TER[MINO/MINALI]; CIL XI 956: DEO TERM.NO DICATUM; Liv. 1, 32, 6: audi luppiter... audi fines; Corpus Glossarium Latinorum II, 197: öpı ı kaı ôpı dieux souverains des Indo-Européens, 12. ${ }^{a}$ ed., Paris, Gallimard, 1977, p. 171-172. Cf. G. WISSOWA, Religion und Kultus der Römer, 2. ${ }^{a}$ ed., München, Beck, 1912, pp. 136-138; W. PöTSCHER, Numen und numen Augusti cit., p. 374-376.

${ }^{470}$ Segundo o ritual, dois proprietários vizinhos encontravam-se junto ao marco sagrado, ofereciam bolos e sacrificavam um cordeiro; as Terminálias, que pertenciam ao calendário de Numa (v. CIL I ${ }^{2} \mathrm{pp}$. 283 e ss.), eram festas estritamente privadas, celebradas pelos fazendeiros (cf. o cerimonial em Sic. Flacc. de cond. agr. in Lachmann 141). Cf. K. LATTE, v. immolatio, in RE, pp. 1116-1117. Segundo H. WAGENVOORT, o marco «divides and maintains its division»; não se trata meramente de um símbolo de 
A sua remoção ou alteração, em virtude do seu numen - a sua dedicação a Terminus -, ${ }^{471}$ implicava a título de sanção a antiquíssima cláusula SACER ESTO, ${ }^{472}$ a expulsão da comunidade dos Quirites $^{473}$ e a perda da sua proteção. ${ }^{474}$

\author{
Segundo Festo, Numa Pompílio teria estabelecido essa severa punição
}

para quem deslocasse os marcos: «Termino sacra faciebant, quod in eius tutela fines

demarcação, mas de algo com um poder próprio de conservação (Roman Dynamism, Westport, Greenwood, 1976, p. 82). Para uma topografia dos limites sagrados do ager romanus, A. ALFöLDI, Early Rome and the Latins, Michigan, Michigan University, s/d, pp. 296-304.

${ }^{471}$ Os confins, como afirma Ovídio, numen habent (Fast. 2, 642: Termine, sive lapis sive es defossus in agro / stipes, ab antiquis tu quoque numen habes). G. PICCALUGA, Terminus: il segni di confine nella religione romana, Roma, Ateneo, 1974, p. 122, afirma que este numen de cada terminus era o deus Terminus, que parecia identificar-se com os marcos, fossem eles pedras ou estacas, cuja função era indicar o perímetro do terreno. Essa afirmação encontra fundamento em Lact. inst. div. 1, 20, 37: lapidem colunt informen ac rudem cui nomen est Terminus. O significado exato de numen é disputado: F. Pfister, v. numen in RE, p. 1273; H. WAGEnVoort, Roman Dynamism cit., pp. 73-83; G. DumÉzIL, Archaic Roman Religion I, Chicago-London, University of Chicago, 1970, pp. 18-31.

${ }^{472}$ Vasta é a literatura sobre o sentido da cláusula; cf. especialmente W. WARDE-FOWLER, The Original Meaning of the Word Sacer, in JRSt 1 (1957), pp. 57-60; K. LATTE, Religiöse Begriffe im frührömischen Recht, in SZ 67 (1950), pp. 50-51; C. GIOFFREDI, Religione e diritto nella più antica esperienza romana - per la definizione del concetto di «ius», in SDHI 20 (1954), p. 264; H. WAGENVOORT, Profanus, profanare, in Mnemosyne $4^{2}$ (1949), p. 319-320; B. ALBANESE, Sacer esto, in BIDR 30 (1988), pp. 145179; outra bibliografia pode ser encontrada em SANTALUCIA, v. Processo penale (diritto romano), in ED 36 , p. 350 , nt. 13 . O significado da sanção sacer esso - mais do que o de um simples tabu - é o de uma intenção normativa de retirar, àquele que cometeu o ato, as garantias usuais do grupo ao qual este pertence, abandonando-o à punição divina, na recente formulação de B. ALBANESE, Sacer esto cit., p. 177. No caso particular do deslocamento dos marcos, afirma R. FIORI, Homo sacer - Dinamica politico-costituzionale di una sanzione giuridico-religiosa, Napoli, Jovene, 1996, p. 204-205, quem o faz infringe a ordem espacial da comunidade e por isso deve ser declarado sacer, essa norma tem uma relevância privatística, por salvaguardar a propriedade individual das terras, e também pública, por proteger os confins de toda a comunidade. Ele nota ainda (idem, p. 207) que o fragmento de Vegóia assimila a violação confinária a um perjúrio (leitura contrario sensu da passagem de Lachmann 351: propterea neque fallax neque bilinguis sis); e associa-o ao fato de que a pena prevista para o perjúrio entre os etruscos - também preocupados com a disciplina da demarcação espacial - era justamente o banimento, a expulsão da comunidade (Serv. in Verg. Aen. 1, 2: est enim libro qui inscribitur terrae iuris Etruriae scriptum vocibus Tagae eum qui genus a periuris duceret fato extorrem et profugum esse debere).

${ }^{473}$ Assim como o pater dono de um fundus compartilha do poder dos Quirites e participa da comunidade (cláusula de cidadania ex iure Quiritium) - nesse sentido, observa P. CATALANo, Aspetti spaziali del sistema giuridico-religioso romano, in Aufstieg und Niedergang der römischen Welt II 16.1, Berlin-New York, W. de Gruyter, 1978, p. 451, a aquisição de um solo pelo populus Romanus Quirites é análoga à aquisição de um terreno por um determinado Quirite, ou melhor, «il potere del singolo è considerato parte del potere del suo populo» (p. 504) -, dela é excluído caso desloque os marcos, procurando aumentar ilegitimamente o seu domínio.

${ }^{474}$ D. SABBATUCCI, Sacer, in Studi e Materiali di Storia delle Religioni 23 (1951/1952), p. 97. 
agrorum esse putabant. Denique Numa Pompilius statuit, eum, qui terminum exarasset, et ipsum et boves sacros esse». ${ }^{475-476}$

A conservação dos termini implica estabilidade ${ }^{477}$ e uma relativa imobilidade, ${ }^{478}$ mantém-se o espaço delimitado, o cosmos em ordem. Por isso o liber

${ }^{475}$ Fest. 505. Duas passagens atestam as reformas de Numa no sentido de instituir as demarcações privadas e públicas: Plut. Num. 16; Dion. Hal. 2, 74.

476 Tão profunda é a marca dessa proibição que, ainda no direito justinianeu, o ato de terminos exarare - descrito com os mesmos termos da lei de Numa - representa um crime. Por exemplo, Paul. 23 ad Ed., D. 10, 1, 4, 5, 1: «Si dicantur termini deiecti vel exarati, iudex, qui de crimine cognoscit, etiam de finibus cognoscere potest». Cf. também Modest. 8 reg., D. 47, 21, 1 pr; Callistr. 3 cogn., D. 47, 21, 2 pr; Callistr. 5 cogn., D. 47, 21, 3 pr. Trata-se do crimen termini moti; enquanto no direito arcaico é prevista a pena de banimento (e possível morte, já que o homício de um sacer não era considerado crime; cf. G. PICCALUGA, Terminus cit., p. 112-113), em várias leis posteriores prevê-se penas menos severas, como a multa pecuniária prevista por uma lei agrária de César mencionada em Callistr. 3 cogn., D. 47, 21, 3 pr (cf. fontes e literatura em R. TAUBENSCHLAG, v. terminus motus in RE, pp. 784-785; F. T. HINRICHS, Die Geschichte der gromatischen Institutionen - Untersuchungen zu Landverteilung, Landvermessung, Bodenverwaltung und Bodenrecht im römischen Reich, Wiesbaden, F. Steiner, 1974, pp. 174-177 ). Mas ainda consta a severa pena - semelhante à do tempo de Numa, a provar a persistência da necessidade de banir da comunidade quem alterasse as fronteiras prevista em PS. 5, 22, 2b: Qui terminos effodiunt vel exarant arboresve finales vel terminales evertunt, si quidem servi ex sua sponte fecerunt, in metallum damnabuntur, humiliores in opus publicum, honestiores in insulam amissa tertia portione bonorum relegantur. Análogo é o "obscurecimento de confins» mencionado por Callistr. 5 cogn., D. 47, 21, 3, 2: qui finalium quaestionum obscurandarum causa faciem locorum convertunt.

${ }^{477}$ Estabilidade espacial e temporal, pois entre os romanos o tempo não é um conceito abstrato, mas «das Wetter mit Beziehung auf die Landarbeit» (K. LATTE, Römische Religionsgeschichte, München, Beck, 1960, p. 64, seguindo uma lição de BENVENISTE). Assim, Numa instituiu, no mesmo período, o calendário e a terminatio; institui além disso o culto a Terminus, definindo a festa correspondente para o dia 23 de fevereiro, dies extremus (Varr. de ling. lat. 6, 13), que fecha o ano romano (cf. A. MAGDELAIN, Cinq jours épagomènes a Rome?, in lus imperium auctoritas cit., pp. 279-303). Ilustra essa idéia a opinião de Varrão expressa por Boécio, Ex dem. artis geom. in Lachmann 393: Varro peritissimus Latinorum huius nominis causam sic extitisse commemorat, dicens prius quidem dimensiones terrarum, terminis positis, vagantibus ac discordantibus populis pacis utilia praestitisse; deinde totius anni circulum mensuali numero fuisse partitum.

${ }^{478}$ A permanência de Terminus no templo capitolino era garantia da inamovibilidade dos confins da civitas romana (Dion. Hal. 3, 69, 6). Quem detinha o imperium, no âmbito dos limites públicos, tinha o poder de propagar esses confins, aumentando (augere) o território (Tac. ann. 12, 23: et pomerium urbis auxit Caesar, more prisco, quo iis, qui protulere imperium, etiam terminos urbis propagare datur); semelhantemente, os terrenos conquistados em guerra eram delimitados em nome do populus Romanus (Liv. 42, 1, 6; Gell. 13, 14: habebat autem ius proferendi pomerii, qui populum Romanum agro de hostibus capto auxerat). Nesse caso, entretanto, obviamente não se tratava de tornar instável ou perturbar a ordem confinária, mas de ampliá-la e, ao mesmo tempo, conservá-la e protegê-la. Por isso só era lícito ampliar o espaço, e fazê-lo legitimamente, através de um representante do populus (G. PICCAluga, Terminus cit., p. 111). O próprio Júpiter tinha o epíteto de propagator, e esse título provavelmente constava nos procedimentos augurais dos antigos harúspices (Apul. de mund. 37: Juppiter... vita nostra auctor... est militaris, est triumphator et propagator, tropaeophoros; et multo plura eiusmodi apud haruspices et Romanos veteres inveneris). Note-se que o ager peregrinus é o território pacatus, pacificado, formado pela expansão a partir do ager romanus, em oposição aos ager hosticus (Varr. de ling. lat. 5, 33). Algo semelhante, como veremos com mais detalhe adiante, ocorria com os terrenos privados, uma vez que «man denkt sich eben den Staat... als einen Hof in größeren Ausmaßen, der die gleichen Institutionem haben muß wie der private Hof» (K. LATTE, Römische 
Vegoia augura terríveis acontecimentos caso alguém desloque os marcos: a condenação dos deuses, extermínio da domus e da família, a doença, tempestades, esterilidade da terra, etc. ${ }^{479}$ Todas essas conseqüências sociais, econômicas, familiares, pessoais e naturais, como assinala G. PICCALUGA, ${ }^{480}$ teriam como causa um fato jurídico: a «mutação do domínio» ocasionada pelo deslocamento dos marcos. ${ }^{481}$

Na imaginação mítico-religiosa dos romanos - não sem efeitos práticos -, a terminatio cria uma unidade espacial ${ }^{482}$ protegida contra a invasão de terceiros; em certo sentido, essa é a percepção que têm os antigos romanos da «propriedade» fundiária. ${ }^{483}$ Para eles é impossível conceber a atribuição de um espaço a alguém

Religionsgeschichte cit., p. 108). Quem entrasse legitimamente na posse de uma terra que ainda não era sua, tinha o poder de ampliar os seus confins, englobando essa nova parcela ao seu terreno (G. PICCALUgA, Terminus cit., pp. 111-112). Repare-se que isso não era possível no que diz respeito à ocupação de terras estrangeiras: só o populus podia conquistar e englobar um terreno não-romano, tornando-o ager romanus segundo o procedimento augural previsto (seria esse o sentido do adágio adversus hostem aeterna auctoritas esto?).

479 Lachmann 350-351: Sed quid contingerit moveritque, possessionem promovendo suam, alterius minuendo, ob hoc scelus damnabitur a diis. Si servi faciant, dominio mutabantur in deterius. Sed si conscientia dominica fiet, caelerius domus extirpabitur, gensque eius omnis interiet. Motores autem pessimis morbis et vulneribus efficientur membrisque suis debilitabuntur. Tum etiam terra a tempestatibus vel turbinibus imbribus atque grandine, caniculis interient, robigine occidentur. Multae dissensiones in populo.

480 Terminus cit., p. 149.

481 Análogo o caso do aluvião: a incerteza a respeito da titularidade da propriedade sobre uma extensão de terra, no plano jurídico, é conseqüência direta da alteração dos confins (mais exatamente, a relação é de mútua implicação). A esse respeito é o trecho de uma constituição de Teodósio e Valenciano em Lachmann 274: Alluvionum, quae contingere solent in praediis que ripis quorundam fluminum terminantur, ea natura est ut semper incerta possessio, incertum sit eius dominium quod possessori per alluvionem adcrescit. Examinaremos mais adiante uma das principais características do usucapião clássico herdada do seu precursor arcaico, que é pôr fim a qualquer espécie de controvérsia a respeito dos confins, ao mesmo tempo em que interrompe definitivamente a controvérsia sobre quem é o proprietário. A auctoritas rerum torna seguro, com apoio no direito dos Quirites, o iura finium descrito pelos antepassados, segundo a passagem de Cic. pro Caec. 74: quid... prodest fundum habere, si, quae diligentissime descripta a maioribus iura finium... haec perturbari aliqua ratione commutarique possunt? [...] usucapio fundi, hoc est finis sollicitudinis ac periculi litis... reliquitur... a legibus... rata auctoritas harum rerum omnium ab iure civili sumitur. Nesse sentido são também os versos de Ovid. Fast. 660: Termine... omnis erit sine te litigiosus ager.

${ }^{482}$ Nesse sentido, afirma E. CASSIRER, Philosophie der symbolischen Formen II, Darmstadt, 1953, p. 124, que o ato fundacional da limitação, ligado à ordenação sacral do espaço, cria a propriedade («Eigentum») em sentido jurídico e religioso.

483 «Das feierliche Umschreiten eines bestimmten Gebiets... grenzt einen inneren Bereich, in dem sich das schützende Heim befindet, gegen einen äußeren, fremden, vielleicht sogar unheimlichen ab» (D. BAUDY, Römische Umgangsriten - Eine ethologische Untersuchung der Funktion von Wiederholung für religiöses Verhalten, Berlin-New York, W. de Gruyter, 1998, p. 96). 
sem o ato fundacional da demarcação, ${ }^{484}$ ou ao menos de atribuição de um modus que possa ser, em seguida, exercido em um terreno concreto. É doutrina comum que toda propriedade fundiária exclusiva - no seu sentido pleno de alicuius esse ex iure Quiritium - de um cidadão romano devia ser «dem Rechtprinzip nach limitiert und adsigniert». ${ }^{485}$

Os fines extremos de um fundus seguem, se possível, os limites da concessão (o suum) ou, conforme o caso, constituem apenas um exercício do usus sobre ele ${ }^{486}$ pendente de confirmação, como veremos com mais detalhe adiante. Eles não se confundem com os limes, que constituem as fronteiras das centuriae e regiones do campo.

Para entender a relação entre os marcos privados e os limites do antigo sistema augural, teremos de voltar à história inicial da propriedade fundiária romana (v. item 3.1), desta vez considerando-a do ponto de vista da instituição da limitatio, ${ }^{487}$

${ }^{484}$ Trata-se de um pressuposto metafísico comum para os antigos, presente, por exemplo, na poesia de Hesíodo. Em theog. 736-743, o poeta expressa que todos os seres existem na medida em que se distinguem do nada; H. FRÄNKEL afirma, a partir dessa passagem, que segundo Hesíodo os limites (no

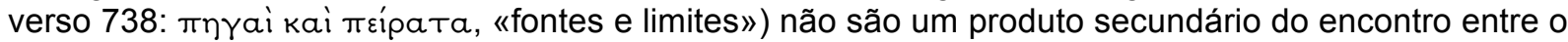
ser e o nada, mas sim o pressuposto primário para todo o ser (Dichtung und Philosophie des frühen Griechentums - Eine Geschichte der grieschichen Epik, Lyrik und Prosa bis zur Mitte des fünften Jahrhunderts, München, Beck, 1962, pp. 117-118).

485 O. BEHRENDS, Bodenheit und privates Bodeneigentum im Grenzwesen Roms, in O. BEHRENDS - L. CAPOGROSSI COLOGNESI (org.), Die römische Feldmeßkunst - Interdisziplinäre Beiträge zu ihrer Bedeutung für die Zivilisationsgeschichte Roms, Göttingen, Vandenhoeck \& Ruprecht, 1992, p. 212; e também «die Grenzen des privaten Bodeneigentums [waren] ein wesentliches Element des privaten Vermögensrechts» (idem, p. 230). Por isso são chamados relicta loca os locais carentes de limitação: relicta autem loca sunt quae sive locorum iniquitate sive arbitrio conditoris limites non acceperunt (Front. in Lachmann 21-22).

${ }^{486}$ Balbi ad Celsum, Exp. et rat. mens. in Lachmann 98: Extremitas est quo usque uni cuique possidendi ius concessum est, aut quo usque quisque suum servat. Essa passagem é importante por dizer literalmente que os fines extremos (extremitates) encerram o suum.

${ }^{487} \mathrm{O}$ assunto é bastante complexo e envolve uma grande quantidade de fontes. Só recentemente ele foi objeto de um estudo aprofundado, com base nos clássicos trabalhos de T. MOMMSEN, M. WEBER e A. RUDORFF; trata-se do artigo de O. BEHRENDS, Bodenhoheit und privates Bodeneigentum im Grenzwesen Roms, in O. BEHRENDS - L. CAPOGROSSI COLOGNESI (org.), Die römische Feldmeßkunst Interdisziplinäre Beiträge zu ihrer Bedeutung für die Zivilisationsgeschichte Roms, Göttingen, Vandenhoeck \& Ruprecht, 1992, pp. 192-280, que contraria a já antiga tendência de restrição ao período tardio (cf. por exemplo M. KASER, Typen des römischen Bodenrechts in der späteren Republik, in SZ 62 (1942), pp. 1-81; o próprio trabalho de F. T. HINRICHS, Die Geschichte der gromatischen Institutionen cit., pp. 224-225, que prefere ignorar qualquer evidência não-arqueológica sobre a gênese da centuriatio e por isso concentra seus estudos sobre o período republicano tardio; e o de E. GABBA, Per un'interpretazione storica della centuriazione romana, in Athenaeum 73 (1985), pp. 265284, que ignora o contexto religioso-augural). Restringimo-nos ao essencial sobre o tema da arte gromática e da ordem augural dos primeiros tempos de Roma, ou seja, ao que é necessário para que 
sempre tendo em conta que, devido às escassez e à incerteza das fontes que remetem ao período régio, nossa investigação recuará apenas, num plano seguro de pesquisa, aos inícios da República, quando mais ao final da Monarquia.

O antigo sistema de limitação augural incidia sobre todo o território romano. No centro está o pomerium, que limita ou ao redor do qual se circunscreve a urbs Roma; ${ }^{488}$ para além dos muros da cidade está o ager Romanus ${ }^{489}$ com o seu

se tenha uma exata compreensão do assunto, evitando questões demasiado polêmicas e especulações. Não sufragamos integralmente a tese de O. BEHRENDS - especialmente no que se refere à sua visão particular da regra do usus auctoritas - mas consideramo-la, no seu núcleo, essencial para a compreensão da propriedade fundiária no período arcaico.

Resumimos a seguir através de dados concretos e fontes os pontos de partida da teoria de $\mathrm{O}$. BEHRENDS (idem, pp. 213-217). Roma possui uma fundação augural, segundo a tradição analística (Liv. 1, 18, 6; 5, 52, 2; Cic. de div. 1, 40, 89), e essa fundação foi usada como modelo para o estabelecimento de novas colônias (Varr. de ling. lat. 5, 143; Gell. 16, 13, 8 ss.); b) Essas colônias eram fundadas segundo um sistema ideal de limitação que incidia sempre sobre um terreno cultivável falx et arater, através da abertura ritual de um sulcus primigenius (Hyg. Grom. in Lachmann 180) que marcava o lugar central da residência e do culto, um quadrado com quatro portas (este local era estabelecido como base do sistema de limitação do solo); c) ao redor desse centro "expandia-se» o campo dividido em centúrias (formadas por unidades menores bina iugera) de acordo com o sistema de limitação; d) o direito fundiário («Bodenrecht») sobre centúrias era concedido a partir desse centro da colônia; e) essa prática prova que Roma foi fundada num lugar delimitado, assim como as suas colônias, segundo o direito augural (Cic. Phil. 2, 40, 102); f) esse sistema apresenta limites estáveis (Fest. 160; Liv. 1, 55, 3) de natureza pública e religiosa e se contrapõe à limitação dos terrenos privados - de natureza mais flexível -, que era feita através do procedimento do fines regere; g) uma colônia nunca podia ser fundada onde outra já existia, a não ser que a primeira fosse "cancelada» através de um contrarius actus (p. 216); h) deve-se levar em conta que a arte gromática ligada a esse sistema de limitação, ou seja, a agrimensura, foi sempre vista como uma prática augural (Hyg. Grom. in Lachmann 170: posita auspicaliter groma, ipso forte conditore presente); i) mais especificamente, as colônias possuem um perímetro central semelhante ao pomerium romano (Gell. 13, 14, 1: Pomerium est locus intra agrum effatum per totius urbis circuitum pone muros regionibus certeis determinatus, qui facit finem urbani auspicii), habitado nos primeiros tempos pelo rei e a partir do qual se expandia o território romano conquistado nas guerras (Gell. 13, 14, 1 in fine: habebat autem ius proferendi pomerii, qui populum Romanum agro de hostibus capto auxerat): o seu núcleo é a sede da jurisdição (inicialmente nas mãos de um rex menor, no âmbito das primeiras magistraturas reais) e serve de residência para os cidadãos da colônia, que vivem da agricultura local (p. 217).

${ }^{488}$ Não se pode dizer ao certo se o pomerium definia os limites de toda a urbe, como queria $P$. CatalAno, Contributi allo studio del diritto augurale, Torino, G. Giappichelli, 1960, p. 301, ou se definia apenas a área central de Roma, como queria I. M. J. VALETON, De templis Romanis, in Mnemosyne 25 (1897), p. 109.

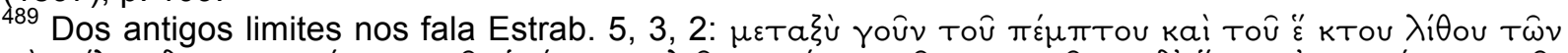

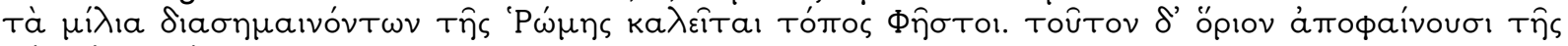

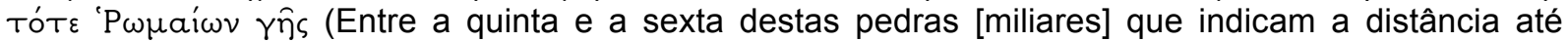
Roma estão os confins daquilo que seria naquela época o território romano). O ager Romanus era também chamado, entre os antigos, ager antiquus (Serv. comment. in Aen. 11, 316: Cato enim in originibus dicit Troianos a Latino accepisse agrum, qui est inter Laurentum et castra Troiana. Hic etiam modum agri commemorat et dicit, eum habuisse iugera iiDCC. Sane 'antiquus' potest et nobilis accipi: vel secundum Trebatium qui de religionibus libro septimo ait "luci qui sunt in agris qui concilio capti sunt, hos lucos eadem caerimonia moreque conquiri haberique oportet, ut ceteros lucos qui in antiquo agro sunt". 'Antiquum agrum' Romanum cogit intellegi). 
solo «limitado» (ager divisus et assignatus) e não-limitado (o ager compascuus, bosque de uso comum, e o ager arcifinius, cujos limites se definem pelos do solo limitado e medido); ${ }^{490}$ junto às fronteiras do ager Romanus está, como já mencionado, o limen mais extremo que o separa do território não-romano. ${ }^{491}$

Dentro desse espaço, os limites internos separam a terra destinada ao cultivo e ao uso individual de várias famílias, sempre auguralmente purificada (objeto do locum effari) ${ }^{492}$ do solo inapto para o cultivo ou destinado a outros fins. ${ }^{493}$

Esse amplo território do ager Romanus era povoado originalmente por pequenas vilas (vici), habitadas por cidadãos romanos, e regiões anexas limitadas e aptas ao cultivo (pagi). ${ }^{494} \mathrm{E}$ é nesse espaço rural dos pagi que tinham lugar as concessões de terra (assignações simples e formação de colônias relativamente autônomas), ${ }^{495}$ atribuições exclusivas em favor de cidadãos romanos que constituem, como vimos, o início do processo de privatização do solo romano, ${ }^{496} \mathrm{e}$

${ }^{490}$ Segundo a classificação dos escritores gromáticos (Front. in Lachmann 1), temos (1) os agri divisi et adsignati, limitados e atribuídos a pessoas concretas (ao menos no caso das centuriae), e que compreendem as centuriae e as terras divididas pela scamnatio e pela strigatio; (2) os agri mensura per extremitatem comprehensi, mensurados mas sem atribuição; e (3) os agri arcifinii, que não são mensurados e, como dito, cuja extensão se mede negativamente, pelos limites das terras limitadas (cf. A. RUDORfF, Gromatische Institutionem cit., pp. 284-302). Acreditamos, com E. BEAUDOUIN, La limitation des fonds de terre dans ses rapports avec le droit de proprieté, in $N R H 17$ (1893), p. 426, que nos primeiros tempos de Roma só houvessem divisões semelhantes a centúrias, introduzidas com as primeiras adsignationes, bem como os não-limitados agri arcifinii, recentes conquistas bélicas (Agg. Urb. in Lachmann 2: arcifinius ager ab arcendis hostibus nuncupatur, seguindo opinião de Varro) que seriam ocupadas muitas vezes pelos patrícios via possessio (Sic. Flac. in Lachmann 138; Front. in Lachmann 5) segundo o esquema que apontamos no item 4.1 (daí serem sinônimos ager arcifinius e ager occupatorius); preferimos não discutir a questão da scamnatio e da strigatio, possivelmente arcaicas, mas que não são diretamente relevantes para o nosso trabalho.

491 O. BEHRENDS, Bodenhoheit und privates Bodeneigentum im Grenzwesen Roms cit., p. 222.

${ }^{492}$ Cic. de leg. 2, 8, 21: urbemque et agros et templa liberata et affata habere.

${ }^{493}$ O. BEHRENDS, Bodenhoheit und privates Bodeneigentum im Grenzwesen Roms cit., pp. 221-222.

${ }^{494}$ Sic. Flac. in Lachmann 164: pagi saepe significanter finiuntur.

${ }^{495} \mathrm{~V}$. item 4.1.

${ }^{496}$ Importante notar, seguindo nosso raciocínio esboçado no item 4.1, o seguinte contraste: a terra até o momento não limitada (portanto ager publicus em sentido estrito, ager occupatorius ou arcifinius) podia ser ocupada por patrícios que tinham esperanças de fazê-la render, e mantinha-se sempre como possessio, sem possibilidade de aquisição exclusiva; já a terra limitada das centuriae, seja ao redor de Roma, seja em colônias distantes (que eram como simulacra de Roma), era perpetuamente concedida a particulares, geralmente plebeus, e constituem a origem do fenômeno da privatização do solo romano, mais tarde consolidado através da regra do usus auctoritas. O princípio dogmático que se extrai dessa situação é a da necessidade de divisio e adsignatio por um auctor (mais tarde considerado apenas um representante da comunidade dos Quirites) a fim de que a terra possa ser usufruída a título exclusivo - eis a origem do que mais tarde chamar-se-á propriedade plena, dominium. 
que se contrapõem à ocupação de terras públicas ainda não limitadas, que podiam ser objeto de possessio. ${ }^{497}$

As adsignationes eram feitas conforme o provavelmente mais antigo sistema de limitação, ${ }^{498}$ a centuriatio, ${ }^{499}$ realizada per kardines et decumanos. ${ }^{500-501}$

${ }^{497}$ Cf. nota adiante.

498 Front. in Lachmann 30: Primum agri modum fecerunt quattuor limitibus clausum; Sic. Flac. in Lachmann 160: Agri dividuntur limitibus structis per centurias; Hyg. Grom. in Lachmann 169: Secundum antiquam consuetudinem limites diriguntur; Hyg. Grom. in Lachmann 166: Inter omnes mensurarum ritus eminentissima traditur limitum constitutio. Est enim illi origo celestis. Não se pode pensar que o sistema é demasiado complexo para os antigos romanos; os egípcios, por volta do ano 2.000 a.C., utilizavam sistemas ainda mais avançados (cf. Herod. 2, 109), e também os gregos a seu tempo (C. SCHUBERT, Land und Raum... cit., pp. 13-42).

${ }^{499}$ E bom notar que nossa teoria não se apóia numa noção técnica de centuriatio, ou seja, na certeza de que ela existisse nos finais do período régio tal como descrita posteriormente pelos escritores gromáticos; ela pressupõe, sim, uma antiga ordem augural e a presença de magistrados que fossem responsáveis pela limitatio. De qualquer modo, embora se possa teoricamente discutir a antigüidade de certos aspectos da limitatio (pensamos primariamente na centuriatio), cremos impossível afastar as numerosas declarações dos escritores antigos a esse respeito. Outras razões são as amplas evidências arqueológicas em favor da medição e limitação visível do solo em terreno itálico, que recuam pelo ao séc. VI a.C. (E. REGOLI, Le prime forme de suddivisione del suolo in Italia, in Misurare la terra: centuriazione e coloni nel mondo romano, Modena, Panini, 1985, pp. 74-75), inclusive segundo um padrão retangular, a exemplo da colonia grega de Olbia, que no séc. VI a.C. foi destruída por um incêndio e reconstruída segundo esse modelo (O. A. W. DILKE, The Roman Land Surveyors An Introduction to the Agrimensores, Newton Abbot, David \& Charles, 1971, p. 23); basta pensar também ainda na cidade de Mileto, reconstruída em 443 a.C. segundo um sistema semelhante ao da centúria (padrão xadrez ou quadriculamento). Um sistema de limitação semelhante ao padrão romano dos cardines et decumani parece ter sido usado em uma cidade na Sicília e em colônias antiquíssimas no Golfo de Taranto e na Caulônia (idem, p. 25); muitos desses planejamentos involvem o envio, juntamento com o fundador, de sacerdotes para a inauguração da colônia, além de agrimensores (idem, p. 24). Todavia, F. T. HINRICHS, Die Geschichte der gromatischen Institutionen cit., p. 224, por exemplo, apesar da tradição analística referir-se à prática da centuriatio já nos inícios de Roma, permanece cético diante da ausência de provas arqueológicas seguras. De fato, os traços significativos mais antigos dessa prática não vão além do ano de 329 a.C, data da fundação da colônia de Terracina (v., por exemplo, F. CASTAGNOLI, Le richerche sui resti della centuriazione, Roma, Storia e Letteratura, 1958, pp. 33-38). Mas é evidente que a inexistência de traços relevantes mais antigos não é uma prova contrária à existência da centuriatio ou de um sistema semelhante, mesmo que mais simples, no período anterior, ao menos nos inícios da República; a mera ausência de dados arqueológicos nem confirma, nem nega, um fato que os próprios romanos tinham por auto-evidente (cf. F. D'IPPOLITO, Questioni decemvirali, Napoli, Ed. Scientifiche Italiane, 1993, p. 13-32), e que outras civilizações mais antigas conheciam. Cremos que não seja possível encontrar vestígios claros do antigo sistema em razão de um fato muito simples: o solo ao redor de Roma, inicialmente pouco extenso em comparação com o espaço ocupado pelas colônias periféricas e tardias, foi totalmente desfigurado pelas sucessivas transformações que lá se deram, já muito cedo. O que se pressupõe aqui é o uso tardio do mesmo padrão arcaico nas colônias periféricas, como os escritores gromáticos e os historiadores romanos não cessam de repetir; e do padrão usado na periferia temos provas arqueológicas seguras e que recuam aos tempos do início da expansão republicana. Esse argumento discute-o C. SCHUBERT, Land und Raum in der römischen Republik - Die Kunst des Teilens, Darmstadt, Wissenschaftliche Buchgesellschaft, 1996, p. 8, especulando, sem no entando emitir um parecer claro, que no centro do ager Romanus as vendas privadas de terrenos - com as conseqüentemente inumeráveis alterações de confins - acabariam por destruir grande parte dos traços da antiga ordem limitante. Essa é, aliás, uma tese de BEHRENDS e BRUGI que discutiremos 
Os limites marcavam as extremidades da terra concedida como um todo e as suas subdivisões ideais, e o resultado era um território recortado, segundo o modelo mais comum, por 100 quadrados de 2 iugera $\left(5.046,68 \mathrm{~m}^{2}\right)$ cada $\mathrm{um}^{502}$ chamado centúria. ${ }^{503}$ Esse tipo de limitação consistia numa operação essencialmente augural. ${ }^{504}$

adiante. F. D'IPPOLITO, Questioni decemvirali cit., p. 32, acredita que uma ampla gama de fontes gromáticas, jurídicas e literárias - entre as quais estão as que amplamente citamos neste capítulo nos leva a «una complessiva conferma della presenza di tecniche di misura terriera nell'età delle XII Tavole», ao menos; no mesmo sentido é a investigação de L. CAPOGROSSI COLOGNESI, Le servitù de passaggio e l'organizzazione del territorio romano in età republicana, in Misurare la terra... cit., p. 29. Mencionamos ainda o amplamente documentado fenômeno dos celtic fields de origem pré-histórica (Idade do Bronze), que envolviam um quadriculamento do solo bastante semelhante ao da centuriatio (cf. a literatura recente em O. BeHRENDS, Bodenhoheit und privates Bodeneigentum cit., p. 243, nt. 148).

${ }^{500}$ Hyg. Grom. in Lachmann 205: agrum more colonico decimanis et kardinibus diviserunt, hoc est per centurias. Os limites inscritos no sentido direita-esquerda eram os mais importantes, denominados kardines ou limites transversi, e se cruzavam com os decimani ou limites prorsi, na direção cimabaixo. O primeiro kardo junto à base do quadrado (mais abaixo) era chamado kardo maximus, o segundo kardo secundus, e assim por diante; o primeiro decumanus à esquerda decumanus maximus, o segundo decumanus secundus, etc (cf. o esquema de T. MOMMSEN, Zum römischen Bodenrecht, in Gesammelte Schriften V, p. 97). Daí o sistema per kardines et decumanos.

501 T. Mommsen, Das italische Bodentheilung und die Alimentartafeln, in Gesammelte Schriften V, p. 123 (=Hermes 19 (1894), pp. 393-416) resume do seguinte modo a relação entre as concessões e a futura propriedade privada (que entendemos como garantia sobre o usus exclusivo e perpétuo, mais tarde "propriedade» assegurada pelo ius Quiritium): «Das Privateigentum am Boden beruht bei den Römern ausschliesslich auf staatlicher Adsignation. Diese wieder hat zu ihrer Voraussetzung die Vermessung und Verzeichnung des vom Staat an den Privaten übergehenden Bodenstücks, wobei es üblich ist den Namen des ersten Erwerbers in eine öffentliche Urkunde einzuschreiben».

${ }^{502}$ Ou então: uma centúria $=100$ heredia $=200$ iugera de $120 \times 240$ pés $=400$ actus de $120 \times 120$ pés $=$ um quadrado de $2400 \times 2400$ pés (5.760.000 pés quadrados ou 51 hectares).

${ }^{503}$ Possivelmente desde os inícios de Roma com esse mesmo nome (Fest. 47: centuriatus ager in ducena iugera definitus, quia Romulus centenis civibus ducena iugera distribuit; Sic. Flac. in Lachmann 153: Centuriis, quarum mentionem nunc facimus, vocabulum datum ex eo. Cum antiqui [Romanorum] agrum ex hoste captum victori populo per bina iugera partiti sunt, centenis hominibus ducentena iugera dederunt: et ex hoc facto centuria iuste appellata est). O que se poderia questionar é se essas centúrias romuléias seguissem exatamente o mesmo esquema das centúrias mais antigas (do séc. IV a.C em diante) descobertas pela arqueologia; disso não duvida, todavia, O. BEHRENDS, Bodenhoheit und privates Bodeneigentum im Grenzwesen Roms cit., pp. 222-223. E. BEAUDOUIN, La limitation des fonds de terre dans ses rapports avec le droit de proprieté cit., p. 409, acredita que a centuriatio era a forma original da limitatio.

${ }^{504}$ E. BEAUDOUIN, La limitation des fonds de terre dans ses rapports avec le droit de proprieté cit., $\mathrm{p}$. 414. Era conveniente que o procedimento fosse realizado diante do auctor ou conditor da centúria (Hyg. Grom. in Lachmann 170). Cf. Cic. Philipp. 2, 102: coloniam quae esset auspicato deducta. Os limites são traçados non sine mundi ratione, seguindo o curso do Sol: os decumani vão nessa direção e os cardines são traçados segundo o eixo vertical da terra ((Lachmann 166). O céu é então divido em quatro partes; a partir da divisão celeste é feita, em espelho, a sua figura no solo, traçada auspicaliter com a groma, o instrumento de agrimensura - os gestos imitam o augur com o seu lituus. O resultado é um templum, ou seja, um local auguralmente enclausurado (Lachmann 167: ex quo haec constitutio liminibus templorum adscribitur; embora a orientação seja diversa da de Hygino, cf. Varr. De ling. lat. 7, 7: eius templi partes quattuor dicuntur, sinistra ab oriente, dextra ab occasu, antica ad meridiem, 
Nem todo o território da centúria era adsignatum, ou seja, atribuído exclusivamente a particulares: algumas parcelas podiam ser dedicadas ao uso comum - e. g., bosques e pasto para os animais, silva et pascua - ou permanecerem sem titularidade, em certo sentido res publica. De qualquer modo, essas parcelas não atribuídas, denominadas mais tarde subseciva, ${ }^{505}$ ficavam sob responsabilidade do soberano responsável pela adsignatio, ${ }^{506}$ o auctor ou fundador da colônia, mais tarde denominado auctor divisionis et adsignationis, ${ }^{507}$ de quem falaremos na seqüência.

Note-se também que - isso será de grande importância para nossa
exposição -, como precisou A. RuDoRfF, as subseciva que permanecem res publica
não podem ser objeto de aquisição pelo usus auctoritas (o que será recorrente em
toda a história do usucapião) ${ }^{508}$ justamente em razão da ausência de uma adsignatio,
ou seja, de um auctor que a tenha realizado ou, ${ }^{509}$ posteriormente, de uma lex. ${ }^{510}$

postica ad septentrionem; Gell. 14, 7, 7: in loco per augurem constituto quod templum appellaretur). A partir da cruz inicial no centro da centuria são traçados os outros limites derivados (Lachmann 167: reliquos limites fecerunt angustiores, et qui spectabant in orientem prorsos, qui ad meridianum, transversos appellaverunt).

${ }^{505}$ Front. in Lachmann 53: Cum enim adsignatio in agro adsignato fierit, non potuit omnis modus intra IIII limites veteranis adsignari. In his subsicivis quidam iterum miserunt quibus agri adsignarentur, quidam et subsiciva coloniis concesserunt; idem, 54: SILVA ET PASCUA... COLONIAE AUGUSTAE CONCORDIAE. Haec inscriptio videtur ad personam coloniae ipsius pertinere, neque ullo modo abalienari posse a re publica.

${ }^{506}$ Front. in Lachmann 8: Est et ager similis subsicivorum condicioni extra clusus et non adsignatus; qui si rei publicae populi Romani, aut ipsius coloniae cuius fine circum datur, sive peregrinae urbis, aut locis sacris aut religiosis aut quae ad populum Romanum pertinent, datus non est, iure subsicivorum in eius qui adsignare potuerit remanet potestate

${ }^{507}$ A. RUDORFF, Gromatische Institutionem cit., pp. 391-392. A prática, ao menos em época posterior, era empreender-se uma nova adsignatio, concedendo-se essas parcelas a novos particulares, ou então vendê-las; havia também outras possibilidades (idem, p. 392).

${ }^{508}$ Mod. 5 reg., D. 41, 3, 18 pr: adversus fiscum usucapio non procedat. Segundo a linguagem antiga, adversus fiscum aeterna auctoritas (!).

509 Hyg. in Lachmann 111: sive quot volet cuius auctoritate fit. Os limites da adsignatio são constituídos e permanecem por força da autoridade daquele que a realiza: limites lege late patere.... debent secundum constitutionem eorum qui agros dividi iusserint (idem).

510 Transcrevemos a passagem pela sua importância crucial: «Von diesem wurden jedoch die subseciva... 5) dem Staate vorbehalten. In [diesem] Falle konnte der Staat sie jederzeit als sein Eigenthum von den Besitzern einziehen, ohne dass diese sich ihm gegenüber auf Usucapion berufen konnten, da sie keinen Auctor und keine Lex hinter sich haben» (idem, ibidem). Em contraposição a isso, quando havia uma concessão específica (via lex), era possível adquirir parcelas subseciva por usucapião, como no caso de uma lei de Domiciano (Suet. Domit. 9: subseciva, quae divisis per veteranos agris carptim superfuerunt, veteribus possessoribus ut usu capta concessit). 
Não é difícil reconstruir o papel desse antigo auctor ou conditor, ${ }^{511}$ peça essencial do antigo sistema de limitação.

São abundantes as referências, entre os escritores gromáticos, ao auctor divisionis et adsignationis ou simplesmente auctor divisionis. ${ }^{512}$ Especialmente nos primeiros tempos da República (e possivelmente no período régio), esse papel é desempenhado pelo soberano responsável pela fundação da colônia, pelo estabelecimento dos limites da adsignatio e pela atribuição das parcelas ideais aos colonos (a cada pater familias), segundo o padrão que estudamos no item 3.1.

Não seria possível sequer imaginar uma adsignatio sem um auctor concreto que a realizasse. Lívio diz que um certo "Aemilius dandi agri plebi fuerat auctor». ${ }^{513}$ Se é fora de dúvida que haviam centúrias ou ao menos adsignationes desde o início da República ou final da Realeza, e que o rex ou o consul não podia

${ }^{511}$ Devemos a O. BEHRENDS o primeiro esboço dessa figura no período arcaico; cf. Bodenhoheit und privates Bodeneigentum im Grenzwesen Roms cit., p. 248-250.

${ }^{512}$ As fontes são as seguintes: Sic. Flac. in Lachmann 157, 7-8 (Inscribuntur quaedam EXCEPTA, quae aut sibi reservavit auctor divisionis et assignationis, aut alii concessit); idem, in Lachmann 157, 11-17 (illud vero...... auctores divisionis assignationisque leges quasdam colonis describunt, ut qui agri delubris sepulchrisque publicisque solis, itineris viae actus ambitus ductusque aquarum, quae publicis utilitatibus servierint ad id usque tempus quo agri divisiones fierent, in eadem condicione essent qua ante fuerant, nec quicquam utilitatibus publicis derogaverunt) Idem, in Lachmann 157, 25-26 (quod factum auctor divisionis assignationisque iustissime propexit); Idem, in Lachmann 160 (aliquando vero in limitationibus si ager etiam ex vicinis territoriis sumptus non suffecisset, et auctor divisionis assignationisque quodam cives coloniis dare velit et agros eis assignare, etc); idem, in Lachmann 162 (auctores enim divisionis assignationisque aliquando subseciva rebus publicis coloniarum concesserunt: aliquando in condicione illorum remanserunt); idem, in Lachmann 164 (aliquibus vero auctores divisionis reliquerunt aliquid agri eis quibus abstulerunt, quatinus haberent iuris dictionem: aliquos intra muros cohibuerunt); idem, in Lachmann 165, 15-17 (de qua re diligenter intuendum erit, ut eos lapides eosque limites comprehendamus, qui postremo per auctores divisionis positi sunt); idem, 165, 18-24 (Praterea [cum] auctores assignationis divisionisque, non sufficientibus agris coloniarum, quos ex vicinis territoriis sumpsissent, [et] assignaverunt quidem futuris civibus coloniarum, sed iuris dictio eis agris qui assignati sunt penes eos remansit ex quorum territorio sumpti erant); Front. in Lachmann 8 (iure subsicivorum in eius qui adsignare potuerit remanet potestate); Hyg. in Lachmann 120 (illud vero observandum, quod semper auctores divisionum sanxerunt, uti quaecumque loca sacra, sepulchra, delubra, aquae publicae atque venales, fontes, fossaeque publicae vicinalesque essent, item siqua conpascua, quamvis agri dividerentur, ex omnibus eiusdem condicionis essent cuius ante fuissent); Hyg. in Lachmann 125 (Scio enim quibusdam regionibus cum adsignarentur agri, adscriptum aliquid per centurias et flumini. Quod ipsum providit auctor dividendorum agrorum, ut quotiens tempestas concitasset fluvium, quo excedens alveum per regionem vagaretur, sine iniuria cuiusquam deflueret); Hyg. in Lachmann 132-133 (haec ergo subsiciva aliquando auctor divisionis aut sibi reservavit, aut [alicui, id est aut] aliquibus concessit aut rebus publicis aut privatis personis)

${ }^{513}$ Liv. 3, 1, 2. O historiador se refere aos inícios da República, antes da publicação das XII tábuas. Auctor, aqui, é o magistrado que realiza a adsignatio de terras aos plebeus. 
se ocupar pessoalmente, ${ }^{514}$ por razões óbvias, da limitatio, é de se presssupor a existência de alguém que exercesse pessoalmente esse papel de conditor. ${ }^{515}$

Segundo os escritores gromáticos, o auctor estabelecia as bases da limitatio, mas não realizava diretamente o trabalho técnico de agrimensura sobre a centúria. Este era feito pelos agrimensores ${ }^{516}$ (anteriormente finitores), ${ }^{517}$ que trabalhavam sob a sua coordenação. ${ }^{518}$ No período imperial era conveniente que o auctor estivesse presente no momento da fundação, ${ }^{519}$ e provavelmente isso seria obrigatório na República.

Os primeiros auctores, ${ }^{520}$ - nas palavras de B. BRUGI, «questi antiqui e
quase leggendari divisori del suolo» $-{ }^{521}$ certamente magistrados, eram os principais

${ }^{514}$ Embora Liv. Per. libr. 1b atribua ao próprio Tarquínio Soberbo a concessão de terras no Aventino: Latinis victis montem Aventinum adsignavit, fines protulit, Hostiam coloniam deduxit, cerimonias a Numa renovavit, é de se imaginar que ela fosse feita em nome do rex, mas através de um magistrado.

515 Cic. de dom. 30 refere-se a P. Lentulus como auctor, iniciador, homem de iniciativa (hic tibi gravissimus auctor ad instituendam, fidelissimus socius ad comparandam, fortissimus adiutor ad rem perficiendam fuit; hic municipia colonias adiit); e aqui, segundo H. WAGENVOORT, Roman Dynamism cit., p. 105, o auctor é «the energetic, influential iniciator». Uma das atribuições mais comuns, e provavelmente mais antigas, de auctor, faz deste propriamente um sinônimo de conditor; cf. $\mathrm{H}$. WAGENVOORT, Roman Dynamism cit., p. 105 e 91-93; Cic. pro Balb. 46; Cic. epist. ad fam. 11, 27, 8; Tac. hist. 3, 43; mas especialmente em Sen. dial. 12, 7, 6-7: Quid interest enumerare Antenorem Patavi conditorem et Evandrum in ripa Tiberis regna Arcadum conlocantem? [...] Romanum imperium nempe auctorem exsulem respicit?; e em Plin. nat. hist. 22, 5: siquidem auctores imperi Romani conditoresque immensum quiddam et hinc, etc. A expressão de Diod. Sic. hist. 37, 11, 1, [oi] ктíбтal

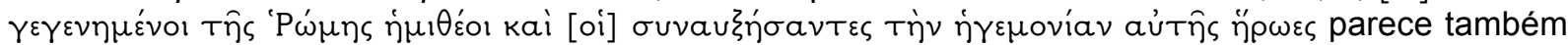
buscar uma tradução grega para o título, aplicado aos semideuses, de auctores imperii conditoresque (cf. a interpretação de T. MOMMSEN, Römisches Staatsrecht /I cit., pp. 783-784, e a de H.

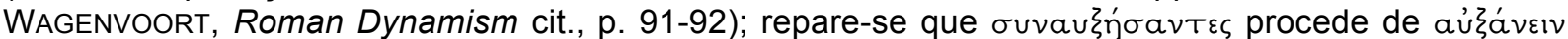
(augere): auctor seria aquele que aumenta o imperium. Cf. também $\mathrm{H}$. WAGENVOORT, Princeps in Philologus 91 (1936), p. 208, 212.

${ }^{516}$ Curiosamente, os melhores agrimensores, que escreviam os tratados de agrimensura, eram também chamados auctores (cf. B. BRUGI, Le dottrine giuridiche degli Agrimensori Romani comparate a quelle del Digesto (1897), reimpress., Roma, L'Erma di Bretschneider, 1968, p. 3; de qualquer modo, esse título aparece em todo o corpus gromático).

517 Nonius (Lindsay 22-23): finitores dicebantur, quos nunc agrimensores dicimus: dicti quod finis dividerent; Plaut. Poen. 48-49: eius nunc regiones, limites, confinia / determinabo: ei rei ego sum factus finitor.

${ }^{518}$ D. FLACH, Römische Agrargeschichte, München, Beck, 1990, p. 21.

${ }^{519}$ Hyg. Grom. in Lachmann 170: Posita auspicaliter groma, ipso forte conditore presente...

520 Procuramos não usar a palavra auctor como um título oficial, mas sim como a função assumida num contexto específico, e de modo particular para designar a relação de dependência entre o colono e aquele que lhe atribuiu a parcela, detentor da auctoritas. Desde que se tenha claro que se trata de uma figura de linguagem, podemos chamar «auctores» aos magistrados que, entre outras funções, eram os encarregados, os iniciadores de uma colônia em sentido estrito ou de uma adsignatio. Para o contexto das fundações, divisões e conservação dos limites, bem como proteção das assignações realizadas e a realização de novas assignações (seja apenas do usus ex auctoritate, seja da propriedade plena), a função mais apropriada é a de auctor (no sentido de eius quid adsignare potuerit 
soberanos no local da colônia ou da adsignatio. ${ }^{522}$ Como os seus sucessores do período republicano médio e tardio (desde o séc. V a.C atuando sempre em colegialidade, até o fim da República), ${ }^{523}$ eles planejariam e realizariam a divisão da centúria $^{524}$ e sorteariam ${ }^{525}$ - um antiqüíssimo costume, se damos crédito a Virgílio 526 as parcelas que cada cidadão ocuparia, ${ }^{527}$ concedendo-as (dando) e indicando (adsignando no sentido literal) $^{528}$ em seguida os fines atribuídos a cada um. ${ }^{529}$

- Front. in Lachmann 8); em outros contextos a palavra auctor não é usada. Estritamente como fundador, o título usado mais tarde é o de conditor ou deductor.

${ }^{521}$ Le dottrine giuridiche degli Agrimensori Romani... cit., p. 115. O autor se refere aos auctores divisionis mencionados pelos gromáticos.

${ }^{522}$ Repare-se, a propósito, que, quando usamos apenas a palavra «colônia» simpliciter, temos em vista não só as colônias em sentido estrito (coloniae), que tinham o seu próprio pomerium, como também as assignações simples, que eram distribuições de terra sem a finalidade de se criar uma nova comunidade independente, embora posteriormente pudesse se tornar praefecturae, fora ou conciliabula (cf. D. J. GARGOLA, Lands, Laws, \& Gods - Magistrates \& Ceremony in the Regulation of Public Lands in Republican Rome, Chapel Hill-London, University of North Carolina, 1995, pp. 102106). Em português talvez não haja um nome genérico adequado («assentamento» dá a idéia de algo pouco organizado e provisório) como o alemão Siedlung e o inglês settlement.

${ }^{523} \mathrm{O}$ número de magistrados encarregados da fundação da colônia, a partir do séc. $V$ a.C., era normalmente o de três, mas também podia variar entre $5,7,10,15$ ou até 20 , conforme o período ( $T$. Mommsen, Römisches Staatsrecht // cit., pp. 628-629. Cf. as fontes na p. 628, nt. 4, 5, 6, e na p. 629, nt. 1 e 2).

${ }^{524}$ D. J. GARGOLA, Lands, Laws, \& Gods cit., p. 87. Em geral, a centúria era instituída em local próximo ao das habitações dos colonos.

525 Sobre a sortitio em geral, há apenas o artigo de V. EHRENBERG, v. Losung, in RE, pp. 1451-1504, pouco informativo. De qualquer modo, o costume de sortear permea toda a vida pública romana.

${ }^{526}$ Quando Virgílio descreve a fundação de uma cidade na Sicília, diz que Enéias urbem designat aratro / sortiturque domos (Aen. 5, 755-756).

${ }^{527}$ A descrição do sorteio feita por Hygino Gromático, na sua especificidade, vale provavelmente apenas para o período tardo-republicano e imperial (cf. Hyg. Grom. in Lachmann 199-201, e também a descrição de Hyg. in Lachmann 113), mas certamente reflete antigas práticas, dado o tradicionalismo romano. Toda distribuição de terras pressupõe um sorteio, ou ao menos uma escolha; em virtude da preferência romana pela sors, temos de pressupor que a sortitio foi utilizada desde as primeiras assignações, especialmente porque esta tinha um caráter augural. Sabendo-se que o auctor tinha poderes augurais, é também de se pressupor que, nos primeiros tempos, a sua presença durante o sorteio fosse necessária. Cf. a detalhada análise de D. J. GARGOLA, Lands, Laws \& Gods cit., p. 95-98, que se concentra sobre o período que começa no séc. VI a.C. e vai até o fim da República.

${ }^{528}$ Daí a descrição para a função do magistrado agris dandis adsignandis, abreviatura a. d. a. Entretanto, embora precisa e aplicável a todos os períodos de evolução dessa magistratura especial, essa descrição só será usada literalmente muito tempo depois (cf. por exemplo Lex Bantia, linhas 13, 16 e 22; a fórmula técnica dare adsignare é do tempo dos Graco, conforme T. MOMMSEN, Römisches Staatsrecht I/ cit., p. 633, nt 4). Para o direito mais avançado da República tardia é preciso, de qualquer forma, distinguir entre dare, que aponta para a atribuição de direito, e adsignare, que traduz o ato de mostrar a parcela limitada ao novo colono (a atribuição de fato, portanto) - assim, ao menos, pensa T. MOMMSEN (idem, pp. 633-634). Nas origens, a adsignatio todavia é um ato imediato e concentrado: a indicação ritual da parcela atribuída já possui, por si, o efeito de atribuir a alguém o direito de «propriedade», o suum sobre o solo limitado.

${ }^{529}$ Hyg. Grom. in Lachmann 204: sortitos in agrum deducemus et fines assignavimus. 
O seu papel, daí em diante, será garantir e conservar a divisão já realizada, servir de juízes em caso de conflito, ${ }^{530}$ conceder o usus ex auctoritate sobre novas parcelas, como explicaremos a seguir, ou mesmo realizar novas assignações a título perpétuo e exclusivo. ${ }^{531} \mathrm{O}$ seu papel, portanto, na consolidação da propriedade fundiária em Roma, é absolutamente central.

De início, não se faz necessária a edição de uma lei especial para a concessão, de modo que a adsignatio e a garantia do direito dela resultante repousa exclusivamente sobre o auctor, ou melhor, sobre a auctoritas pessoal do magistrado; ${ }^{532}$ isso está de acordo com a natureza carismática do poder na Realeza e nos inícios da República. Evandro, o mítico auctor da colônia de Roma segundo a versão grega, como dizia Lívio, auctoritate magis quam imperio regebat loca; ${ }^{533} \mathrm{e}$ repare-se que regere significa também dividir e limitar (como em fines regere).

Como vimos, é bastante improvável que as primeiras concessões de terra fossem rigorosamente paritárias, e que permanecessem estáticas. Mesmo que cada um recebesse inicialmente apenas parcos 2 ingera (um heredium), teria o auctor o dever de velar para que, segundo o trabalho e a condição de cada colono, Ihes fosse concedido o necessário para a sua subsistência. ${ }^{534}$

\footnotetext{
530 Sic. Flac. in Lachmann 164: aliquibus vero auctores divisionis reliquerunt aliquid agri eis quibus abstulerunt, quatinus haberent iuris dictionem: aliquos intra muros cohibuerunt.

${ }^{531}$ Diferentemente do que ocorrerá com o direito ligeiramente posterior, nos inícios da República - no período decenviral, portanto - são os magistrados os que detêm o direito de conceder terras, e não o Populus diretamente (T. Mommsen, Römisches Staatsrecht II cit., p. 627). Em certo momento a propriedade privada das parcelas deixará de ser garantida pelo auctor e passará a repousar sobre o direito dos Quirites.

${ }^{532}$ Como pano de fundo, tenhamos em conta a observação de MOMMSEN de que uma das diferenças mais importantes entre a constituição monárquica original e a da República posterior é que a distribuição de terras aos particulares, na primeira, é um direito do magistrado e, na segunda, um direito do Populus (Römisches Staatsrecht II cit., p. 624). Segundo o princípio esboçado por A. RUDORFF, Gromatische Institutionem cit., p. 392, como já mencionamos, é impossível adquirir um solo não limitado e assignado (e essa é a origem da proibição do usucapião de terras públicas); em razão disso, o fundamento da aquisição repousa, em última instância, sobre o auctor da limitação e da adsignatio. Mais tarde, com a passagem do poder de conceder terras dos magistrados ao Populus, o fundamento legal passa a ser a lex editada para esse fim (para os detalhes, cf. T. MOMMSEN, Römisches Staatsrecht I/ cit., p. 625-626), embora, no plano do direito privado, a propriedade fosse já autonomamente garantida pelo direito civil (ius Quiritium).

${ }^{533}$ Liv. 1, 7, 8. Cf. também o relato dessa versão da fundação de Roma em Estrab. 5, 3, 3.

${ }^{534}$ Não há praticamente vozes dissonantes com respeito à já consolidada opinião dos historiadores que citamos no item 1 deste capítulo: apenas 2 iugera não bastavam para a subsistência sequer de uma pequena família, de modo que é necessário que os colonos tivessem acesso não só aos bosques de uso comum, mas também a mais parcelas de terra arável. A grande diversidade no que diz
} 
Com efeito, além de um espaço de terra para a construção de uma villa e de um solo relativamente exíguo para o cultivo, ambos adquiridos perpetuamente pela adsignatio original, o colono podia seguramente conquistar para si, com a autorização (auctoritas) do magistrado, ${ }^{535-536}$ o usus sobre mais parcelas disponíveis dentro do sistema da limitatio, ${ }^{537}$ ou mesmo a propriedade sobre elas: subsiciva ut usu capta concess[a]. ${ }^{538}$

respeito ao tamanho dos fundi que vemos já nos inícios da República pressupõe que, de alguma maneira, tenha sido possível a aquisição do usus ou até mesmo da propriedade exclusiva, com possibilidade de alienação, sobre mais parcelas do que aquelas originalmente concedidas pelo «Estado» e distribuídas pelos magistrados. Essas novas aquisições pressupõem, por sua vez, a autorização do auctor responsável pelo território limitado: eram parcelas anteriormente não assignadas (subsecivae no contexto das centúrias) que foram convertidas em terreno disponível. Sem a «liberação» da parcela à apropriação individual não é possível, como vimos, adquiri-la.

${ }^{535}$ Uma analogia pode ser feita com a auctoritas do tutor: o pupilo, sem ela, não pode começar a possuir (Paul. 54 ad Ed., D. 41, 2, 1, 3: pupillus sine tutoris auctoritate non potest incipere possidere).

A referência a uma auctoritas está presente nos escritores gromáticos, embora escrevessem num tempo em que ela já não representava, como tal, um papel importante na conservação da propriedade; num tempo em que os já antigos procedimentos da limitatio, juntamente com os seus contextos, já estavam perdendo ou já tinham perdido a sua validade (D. J. GoRGOLA, The Ritual of Centuriation, in C. F. KONRAD (ed.), Augusto augurio - Rerum humanarum et divinarum commentationes in honorem Jerzy Linderski, Stuttgarg, F. Steiner, 2004, p. 123). Temos uma referência indireta a ela em Hygino (Lachmann 111): os limites devem ser estabelecidos secundum constitutionem eorum qui agros dividi iusserint; e outra direta (idem, ibidem): maximus decimanus et cardo plus patere debet, sive..., sive quod volet cuius auctoritate fit. Dos dois fragmentos se extrai que o auctor da colônia tinha um poder total sobre a limitação original; e de outros fragmentos, que também o tinha sobre a distribuição de novas parcelas, como o demonstramos ao tratar das subsecivae. A história do uso da palavra auctoritas nesse contexto não termina aqui. Várias limitationes entre regiões serão feitas explicitamente - como comprovam as respectivas inscrições ex auctoritate de um magistrado: por exemplo, CIL III 591; X 1018; XII 113. Os exemplos são muito numerosos.

${ }^{536}$ Enquanto nos primeiros tempos a auctoritas era o elemento mais importante na definição dos confins - por incidir sobre as parcelas originalmente definidas de acordo com a limitatio -, posteriormente, com a privatização total dos fundi, passam a valer também os limites privadamente fixados através dos marcos, muitas vezes fruto do consenso entre vizinhos de terrenos confinantes (convenientia... possessorum terminos consecrat). Isso supõe uma verdadeira revolução. $O$ ius Quiritium passa então a garantir o suum não só sobre as parcelas ideais, produto da limitatio original, e que podiam ser reestabelecidas pela controversia de modo, como veremos, mas também sobre a área concreta e limitada do fundus (daí a futura denominação fundus optimi iure privato) resultado de uma série de alterações privadas: alienações de partes de um fundus, convenções entre vizinhos sobre os limites, etc. Esse estado de coisas acabará por destruir parte da antiga ordem augural, embora a parcela da adsignatio original continue objeto da auctoritas.

${ }^{537}$ Isso já vínhamos esboçando desde o primeiro item deste capítulo, procurando aprofundar tese já intuída, a seu tempo, por C. W. WESTRUP, e recentemente também por O. BEHRENDS, Bodenhoheit und privates Bodeneigentum cit., p. 250 , em que pese os seus erros a respeito da natureza da auctoritas decenviral. Ao tema da origem da usucapio, voltaremos mais tarde.

${ }^{538}$ Literalmente em Suet. Dom. 9, 3. 
Esta seria um dos contextos prováveis da usucapio, ${ }^{539}$ ao menos em época histórica, ao lado da mais antiga usucapio pro herede, que não teremos oportunidade de examinar em detalhe. A novidade introduzida pela regra das XII tábuas, como veremos com mais detalhe adiante, foi a exigência de um prazo de 2 anos e a gradual substituição da auctoritas pessoal do magistrado, de caráter provavelmente augural, ${ }^{540}$ por uma auctoritas provinda da comunidade dos Quirites

\footnotetext{
${ }^{539}$ A coesão da tese sobre a regra decenviral do usus auctoritas que começamos a propôr só seria derrubada se se provasse que se trata de mera coincidência: 1) o fato de que a propriedade fundiária em Roma surgiu a partir da concessão de terras, assignações simples e colônias; 2) o fato de que os responsáveis pela adsignatio dessas terras eram chamados, com razão, auctores; 3) o fato de que esses auctores, com base na sua auctoritas, podiam conceder a particulares o usus de mais parcelas da limitatio de onde procederam as assignações originais; 4) o fato de que a lei das XII tábuas, editada justamente nesse período em que a propriedade privada já está se consolidando, traz uma regra sobre a aquisição de terras (cuja primeira titularidade é sempre resultado uma adsignatio) que diz que, após 2 anos, tem-se sobre o fundus «o usus e a auctoritas»; 5) o fato de que uma terra ainda não assignada (parcelas subsecivae), ou seja, não concretamente concedida, nem que seja a título de usus, por um auctor, não podia ser usucapida pela regra das XII tábuas.

${ }^{540}$ Não pretendemos atribuir demasiada importância à teoria, de qualquer modo bastante sólida, da conexão entre a auctoritas e a prática augural, uma vez que nosso trabalho tem como foco o direito privado e a sua gênese. Dado o caráter augural da própria limitação, não só a primeira divisão como as posteriores assignações necessitam de uma "confirmação» também augural; o próprio significado antigo de ius que esboçamos no item anterior está implicado nesse processo (o auctor da colônia, como dissemos, possuía a iuris dictio sobre o seu território). Embora pouco atenta aos detalhes e aos contextos, a relativamente recente tese de P. FUENTESECA, que estudamos no capítulo anterior, é a primeira a incluir explicitamente uma referência ao direito augural; ainda mais abstrata, embora na mesma linha, é a mais recente tese sobre o tema, de autoria de F. C. CASINOS-MORA, segundo a qual a auctoritas decenviral representa uma vaga «fonte de legitimidade ou fundamento público do poder de domínio sobre as coisas» (La noción romana de auctoritas... cit., p. 267).

Sabemos que tanto augur como auctorlauctoritas procedem de augere, aumentar, acrescentar, embora auctor/auctoritas traga sempre a idéia de uma criação, de uma iniciativa; a mais autorizada teoria atualmente é nesse sentido (É. BENVENISTE, Le vocabulaire des institutions indo-européenes II Pouvoir, droit, religion, Paris, Minuit, 1969, pp. 148-151). É segura a conexão entre o fundador da colônia, que realiza a limitatio segundo práticas de raiz tipicamente augural, tendo como resultado um templum, e a atividade do próprio augur. O augurium é, com efeito, um acréscimo divino sobre uma atividade humana, no sentido de uma "autorização» (P. CATALANO, Contributo allo studio del diritto augurale cit., p. 23-24); de certa forma, é o que faz o auctor ao purificar a terra (o locos effari é marcadamente uma atividade augural: Theaurus Linguae Latinae V, 2, p. 199), realizar a divisão e atribuí-la a particulares, tornando-a «magicamente» apta a ser cultivada segundo o sistema de limitação (o que pressupõe o poder de transformar parte do ager Romanus, o primeiro na lista dos tipos de solo segundo o direito augural, em ager privatus), ação que como um todo implica uma inauguratio (cf. P. CATALANO, Contributo... cit., p. 248, para as fontes). Todavia, o auctor é essencialmente um magistrado civil, embora sua origem régia implique uma função augural (cf. a nota abaixo sobre o uhtur).
} 
(ius Quiritium), ${ }^{541}$ mais tarde generalizada como prova absoluta de propriedade quiritária consubstanciada na adsignatio (auctoritas census?). ${ }^{542}$

Abramos um pequeno parênteses. Uma comparação até hoje não explorada reforça essa tese sobre a função «terminal» da auctoritas, no sentido de garantia de uma limitatio por um auctor, embora aqui em sentido corpóreo (nossa tese pretende enfatizar a auctoritas sobre uma medida ideal, que necessita ser exercida pelo usus dentro de confins certos). É conhecida a associação, até hoje inquestionada, ${ }^{543}$ entre o auctor romano e o uhtur úmbrico (como no caso do censorlkeenzstur), um magistrado civil $^{544}$ que, nas Tabulae lguvinae, também desempenha um papel cerimonial. Não foi notado, entretanto, o parentesco entre essas duas figuras do ponto de vista do seu papel no âmbito da limitatio. Examinemos a seguinte inscrição de Assis: ${ }^{545}$

${ }^{541}$ Segundo a passagem de Cícero já comentada: auctoritas ominium rerum [i. e., fundi, iura finium] a iure civile sumitur - a auctoritas sobre o terreno e sobre os seus limites provém do direito civil.

${ }^{542} \mathrm{~V}$. adiante.

${ }^{543}$ Segundo o estudo mais recente sobre o tema, o uhtur, sempre traduzido como auctor pelos filólogos (cf. I. Devoto, Tabulae Iguvinae, Romae, Regiae Officinae, 1937, p. 370: «etymologiam omnes auctores ad 'auctor' referunt»; A. WALDE / J. POKORNY, Vergleichendes Wörterbuch der indogermanischen Sprachen I, Berlin-Leipzig, Walter de Gruyter, 1930, p. 22; J. W. POULTNEY, The Bronze Tables of Iguvium, in Philosophical Monographs - American Philological Association n. XVIII (1959), p. 201), era um magistrado cujas origens remontam ao rex romano e mesmo a uma figura similar pré-romana, associado às antigas categorias Auctor/Augur/Rex - favorável à tese de $\mathrm{O}$. BEHRENDS, que crê ser o auctor do período régio um rex menor (Klein-Rex), dotado de soberania sobre o solo real -, mas cujo papel é mais laico que religioso, embora não fosse possível, no contexto das Tabulae Iguvinae, separar de foma clara e distinta esses dois âmbitos (W. A. BORGEAUD, Fasti Vmbrici - Études sur le vocabulaire et le rituel des Tables eugubines, Ottawa, Universitè d'Ottawa, 1982, pp. 43-85). Auctor seria um antigo qualificativo do rex e, ao mesmo tempo, "un rajeunissement du term primitiv augur que se vit alors confiné dans une sphère purement religieuse et technique» (idem, p. 48); trata-se de alguém que, sem ser um augur no sentido estritamente técnico-religioso, reúne também as suas qualidades - já que na sua origem o *Rēĝ-s exercitaria diretametne o *augos-, a capacidade de consultar os pássaros, detendo a função de *sakro-dhakelo-s > Sacrificulus, sacrificador, mas também a de *lou-dik-s > Jüdex, juiz, ou *Prai-itor > Praetor, e a de Auctor; mais tarde, a forte tendência do rex de deixar-se representar levou a um transferência desses papéis específicos aos seus magistrados (idem, p. 49).

${ }^{544}$ A antiga dúvida a respeito da laicidade do seu cargo foi desfeita com a descoberta desta inscrição funerária de Mevânia (P. PoccetTI, Nuovi documenti italici, Pisa, 1979, doc. n. 3): PE.PE.UfEŘIER.UHTUR. O equivalente latino seria: $\mathrm{Pe}$ (tro) $\mathrm{Pe}$ (tronis filius) Aufidius, auctor. $\mathrm{O}$ fato de uhtur vir após o nome do magistrado sem nenhuma especificação indica a ausência de uma pertença a um colégio sacerdotal (esperava-se fosse o auctor das Tavolae Iguvinae um dos Fratres Atiedii) e confirma a sua laicidade (E. CAMPANILE / C. LETTA, Studi sulle magistrature indigene e municipali in area italica, Pisa, Giardini, 1979, p. 50).

${ }^{545}$ CIL XI 5389; inscrição reproduzida exatamente aqui da ed. impressa do CIL. Trata-se de uma estela de calcário encontrada em 1742. Como afirma A. RosenBERG, Der Staat der alten Italiker Untersuchungen über die ursprüngliche Verfassung der Latiner, Osker und Etrusker, Berlin, 


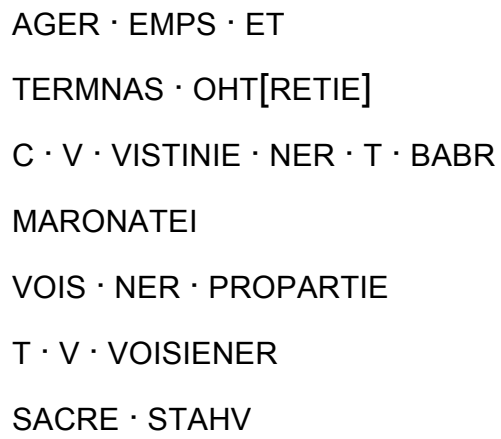

Nesse caso, temos dois uhtur/auctores - detentores da oht[retie] ou auctoritas - acompanhados de dois magistrados de natureza inferior, ${ }^{546-547}$ os marones; estes últimos têm, na inscrição demarcatória, a função de registro temporal: «no maronato de V. Propercius e T. Voisiener». ${ }^{548}$

Já os auctores estão ligados à terminatio do ager: "o terreno foi adquirido e limitado sob a auctoritas [ohtretie] de C. Vistinius e Ner. Babrius». ${ }^{549}$ A clareza da inscrição dispensa maiores considerações. Só resta notar que a cláusula SACRE STAHV, sacer sto, dá um caráter público ao documento.

O uhtur era provavelmente o líder soberano, não-colegial, da comunidade umbra em tempos pré-urbanos; ${ }^{550}$ podemos afirmar, dada a sua vizinhança com os romanos como povo itálico e com base na literalidade da inscrição citada, que ele seria o primeiro responsável pela conservação dos limites entre as terras umbras nas mãos de particulares (ager terminatus ex auctoritate). Isso sugere uma analogia com o magistrado romano, soberano (antes do séc. $V$ a.C. também não-colegial) no espaço da colônia e garantidor da limitatio. Todavia, uma clara diferença entre eles é que este último não ostentava esse nome como título oficial de

Weidmann, 1913, p. 47, «die sprachliche Deutung auch dieses Textes ist ganz sicher». A versão latina proposta pelo autor é a seguinte: ager emptus et / terminatus auctoritate / C. Vistinie V. f., Ner. Babr. T. f. / in maronatu / Vois. Propartie Ner. f. / T. Voisiener V. f. / sacrum sto.

${ }^{546}$ E. CAMPANILE / C. LETTA, Studi sulle magistrature... cit., p. 54.

547 «Auctores duo sunt, duobus magistratibus qui 'marones' appellantur» (I. DEVOTO, Tabulae Iguvinae cit., p. 371).

${ }^{548}$ Compare-se CIL IX 4182 e 422; X 1233 bis; XIV 2097.

${ }^{549}$ Cf. a tradução de C. D. Buck, Elementarbuch der oskisch-umbrischen Dialekte, Heidelberg, Carl Winter, 1905, p. 191.

${ }^{550}$ E. CAMPANILE / C. LETTA, Studi sulle magistrature... cit., p. 60, nt. 137. 
uma magistratura: ${ }^{551}$ ao menos em tempos históricos, ele apenas assumia a «posição de aucton», e isso em um contexto específico. ${ }^{552}$

\subsection{Limitatio e propriedade quiritária, fundus-participação}

\section{e modus agri, usucapio pro herede: mais elementos para a interpretação da regra do usus auctoritas}

Um dos romanistas que mais se dedicaram ao estudo da questão da terra em Roma e dos seus reflexos sobre o direito civil, L. CAPOGRossı CologNESI, afirmou que a noção de uma antiga ordem augural, intuída por autores como Mommsen, Beaudouin, Brugi e recentemente O. Behrends, implica uma grande mudança de paradigma em nossa visão sobre a primeira noção da propriedade fundiária romana. ${ }^{553}$

Um dos princípios mais importantes nesse contexto é o de que a propriedade quiritária, o suum ex iure Quiritium que mais tarde será o direito resultante do usucapião clássico, como vimos, tem origem em espaços delimitados segundo esse antigo sistema.

O padrão recorrente na tradição analística ${ }^{554}$ é que a propriedade privada se iniciou com a divisão e a concessão de terras por Rômulo através do sistema da centuriatio. ${ }^{555}$ Não sabemos exatamente quando isso historicamente

\footnotetext{
${ }^{551}$ Como o consulado, a questura, a pretura, etc.

552 É possível que, originalmente, também entre os romanos tenha existido alguém que recebesse oficialmente o nome de auctor, como sempre ocorreu com augur, mas não há nenhuma fonte que o indique. Em tempos históricos, ser auctor é assumir uma posição de garante, de iniciador, de prestígio, de alienante, etc, sempre num contexto determinado.

553 Intervenção no Simpósio ocorrido em Göttingen entre 5 e 9 de junho de 1988 (cujos trabalhos compõem o já citado Die römische Feldmeßkunst), transcrita por Cosima Möller como apêndice ao artigo de O. BEHRENDS, Bodenhoheit und privates Bodeneigentum... cit., p. 282-283.

${ }^{554}$ Tradição que aos poucos, desde as últimas descobertas arqueológicas, se tem confirmado. Como disse A. ALFÖLDI, «Die Existenz eines blühenden Rom mit städtischer Zivilisation im 6. Jahrhundert war durch die archäologische Evidenz tatsächlich gesichert» (na tradução alemã de F. Kolb, Das frühe Rom und die Latiner, Darmstadt, Wissenschaftlische Buchgesellschaft, 1977, p. 283).

${ }^{555}$ Usualmente cético, o próprio F. CASTAGNOLI observa que «la centuria in età più antica [era] usata solo nelle colonie romane», e que «sembra da ritenere esatto quello che si è ricevuto dalla tradizione, che la centuria comprendese in origine 100 campi» (Le ricerche sui resti della centuriazione cit., p. 32).
} 
aconteceu, ${ }^{556}$ mas podemos dizer que, em termos gerais, essa tradição dá conta da simultaneidade entre a propriedade exclusiva e a limitatio no período pré-decenviral, marcado pela dominação etrusca. ${ }^{557}$

Não se pode questionar (e nem exagerar), a propósito, a influência etrusca ${ }^{558}$ sobre as relações entre a limitatio e a propriedade fundiária no séc. VI a.C. Basta considerar o testemunho unânime das fontes no sentido de que a disciplina de demarcação de terras romana teve origem na disciplina etrusca, ${ }^{559}$ bem como o fato

${ }^{556}$ Certamente antes da lei das XII tábuas, pois uma lei anterior a ela, a lex Icilia de Aventino (456 a.C), já menciona um regime exclusivo de apropriação da terra, segundo um esquema que lembra o das centuriae e pressupõe algum tipo de limitação. Se a legislação decenviral pressupõe ao menos um século de experiência com a propriedade privada - o que é razoável pois, como vimos, se trata de uma fixação de costumes já existentes -, podemos recuar até o séc. VI a.C, ao período entre a dominação etrusca (dos três últimos reis) e a expulsão dos Tarquínios. Arqueologicamente, o séc. VI é marcado, segundo os dados analisados por GJERSTAD, pela unificação das vilas pré-existentes a Roma e pela ereção do Fórum (circa 575 a.C; cf. E. GJERSTAD, Early Rome I cit.; compare-se A. MOMIGLIANO, Terzo contributo, in JRSt 53 (1963), p. 95 e ss.).

${ }^{557}$ L. CAPOGROSSI ColognesI, Proprietà e signoria in Roma antica I cit., p. 52. O mesmo autor observa que a tendência de se garantir ao máximo a autonomia da posse sobre parcelas de terra, fenômeno esse inserido na limitatio dos fundi, corresponde perfeitamente ao caráter típico das sociedades agrícolas (II regime della terra nell'età repubblicana, in L. CAPOGROSSI COLOGNESI, La terra in Roma antica - Forme di proprietà e rapporti produttivi I, Roma, La Sapienza, 1981, p. 249).

${ }^{558}$ Cf. especialmente A. ALFÖLDI, Römische Frühgeschichte cit., pp. 161-167.

${ }^{559}$ Front. in Lachmann 27: Limitum prima origo, sicut Varro descripsit, a disciplina Etrusca; Hygin., in Lachmann 166: Unde primum haec ratio mensurae constituta ab Etruscorum haruspicum disciplina; Varr. de ling. lat. 5, 32, 143: Oppida condebant in Latio Etrusco ritu; Plut. Rom. 11: 'O $\delta \dot{\varepsilon}$ 'P $\omega \mu u^{\prime} \lambda$ os $\varepsilon v$

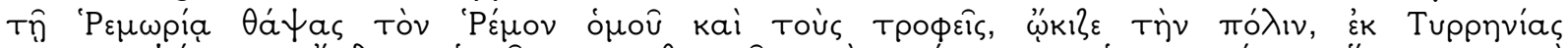

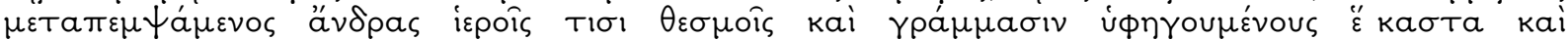

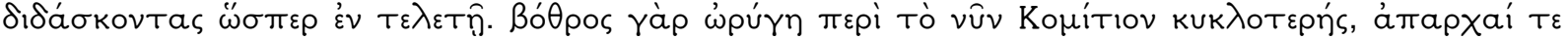

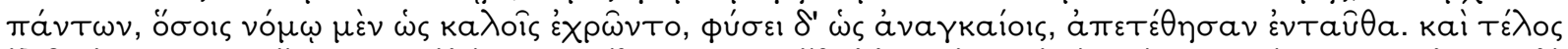

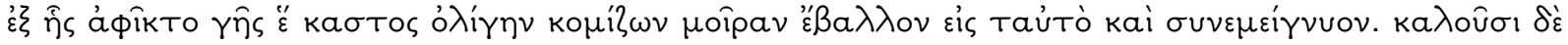

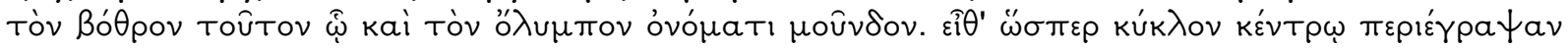

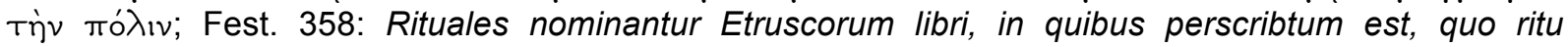
condantur urbes, arae, aedes sacrentur, qua sanctitate muri, quo iure portae, quomodo tribus, curiae, centuriae distribuantur. Parte dos autores modernos confia nessas fontes (G. FRANCIOSI, La limitatio nell'ager campanus, in G. FRANCIOSI (org.), La romanizzazione della campania antica I, Napoli, Jovene, 2002, p. 1-2. Cf. bibliografia sobre a questão da origem à p. 1, nt. 2). Como observou P. CATALANO, Aspetti spaziali del sistema giuridico-religioso romano, in Aufstieg und Niedergang der römischen Welt II - 16.1, Berlin-New York, W. de Gruyter, 1978, p. 483, nt. 165, dizer que a limitatio tem origem etrusca é diferente de afirmar que o sistema do kardus et decumanus é puramente etrusco. F. CASTAGNOLI, Le ricerche sui resti della centuriazione cit., p. 21 , acredita que a ela tenha origem grega; mas isso em nada altera nossa pesquisa. É inegável, repare-se, a relação entre gregos e etruscos (F. WIEACKER, Römische Rechtgeschichte cit., p. 204: «durch Südetrurien vermittelte griechische Einflüsse»; cf. em geral L. AIGNER-FORESTI, Zeugnisse etruskischer Kultur im nordwesten Italiens und in südfrankreich - Zur Geschichte der Ausbreitung etruskischer Einfüsse und der etruskisch-griechischen Auseinandersetzung, Wien, Öst. Akademie der Wissenschaften, 1988); prova disso, no contexto em que nos movemos, é o nome do principal instrumento de agrimensura, a groma, procedente do grego $\gamma \nu \omega ́ \mu \omega \nu$ através do etrusco gruma (cf. W. SCHULZE, «Sitzungsberichte» na Akad. Berlin em 6 de julho de 1905, p. 709; também a palavra gramma em Polyb. 6, 41, 6, que designa o 
de que o heredium romano, de dois iugera, correspondia exatamente a um acnua etrusco $\left(5.000 \mathrm{~m}^{2}\right) .{ }^{560}$ Reconhecer essa origem da limitatio é fazer recuar ao menos até o séc. VI - ao ápice da dominação etrusca sobre Roma - o uso dessa técnica e do regime correspondente, exatamente à época em que começa a avançar a agricultura no Lácio. $^{561}$

auguratorium, o lugar onde se captam os auspícios). Por isso é possível que a própria agrimensura ou rudimentos dela - tenha chegado aos romanos através dos etruscos, os quais por sua vez a teriam herdado dos gregos. A cidade de Nápoles é uma colônia grega e, segundo o importante estudo de K. J. BELOCH, Campanien, Breslau, 1890, p. 66, a sua fundação no séc. VII-VI a.C segue esquema idêntico ao dos antigos gromáticos romanos. O clássico C. O. THULIN, Die etruskische Disciplin III Die Ritualbücher und zur Geschichte und Organisation der Haruspices, Darmstadt, Wissenschaftliche Buchgesellschaft, 1968, p. 26-32, está convencido, diante dessas e outras provas que ele mesmo aduz, da origem etrusca da limitatio. A sua summa argumentativa constitui-se dos seguintes pontos: a) a afirmação segura dos escritores gromáticos e de Varrão no sentido dessa origem da limitatio; b) a presença do fragmento de Vegoia entre os escritos gromáticos; c) o parentesco comprovado entre o latim groma e o etrusco gruma, que designam o principal instrumento utilizado na limitatio; d) o uso da medida actus, originalmente etrusca (a terminação -ua é a mesma do nome das cidades etruscas Capua e Mântua; o "prefixo» ac-, acn- é também etrusco), alheia aos latinos, por seguir o sistema duodecimal -12 é, aliás, o número das cidades pertencentes à federação da Etrúria - e não o decimal; e) os indícios no sentido de que os sacerdotes etruscos tenham sido excelentes engenheiros e hidrógrafos, bem como mestres dos romanos na arte de construir estradas; f) a orientação dos gromáticos no sentido leste-oeste (decumanus), que representa a totalidade do mundo dividida em um dia e uma noite, está presente também numa peça de bronze etrusca de Piacenza; g) a colônia etrusca de Felsina, do séc. VI a.C., cujo plano parece seguir de modo exemplar a mesma orientação (ratio pulcherrima) indicada por Hygino, in Lachmann 180, onde supõe-se a presença de um kardo na direção sul-norte e três grandes decumani na direção leste-oeste. Mais adiante - após analisar dados recolhidos por Pigorini, Luigi Scotti e Quagliati, que indicam colônias desde a Idade do Bronze cujos rastros indicam a presença da limitatio, inclusive segundo o padrão quadriculado -, o autor supõe também que os etruscos teriam aprendido a agrimensura dos gregos (p. 39).

${ }^{560}$ Varr. res rust. 1, 10: Latino iugeris iugum vocant, quod iuncti boves uno die exarare possint. versum dicunt centum pedes quoquo versum quadratum. iugerum, quod quadratos duos actus habeat. actus quadratus, qui et latus est pedes cxx et longus totidem: is modus acnua latine appellatur. SANTO MAZZARINO argumenta, com base nisso, que os etruscos foram, para os romanos, os portadores da cultura urbana; essa cultura significa, precisamente, "distinzione confinaria», principalmente no que diz respeito às limitações entre os pagi. A isso soma-se o forte indício do vocábulo etrusco tular, massivamente presente nas fontes, cujo significado - o mais certo entre todos os vocábulos incluídos no Corpus Inscriptionum Etruscarum - é precisamente "confim», "fronteira» ou ainda "marco» (Sociologia del mondo etrusco e problemi della tarda etruscità, in Historia 6 (1957), pp. 102-103). Por isso, diz D. J. GORGOLA, The Ritual of Centuriation cit., p. 128, «the resemblances between the orthogonal axes of centuriation and certain [originally etruscan] techniques of divination are too close to be dismissed easily».

${ }^{561}$ No mesmo sentido, J.-H. MICHEL, L'usucapio des immeubles durait-elle deux ans?, in Hommage à René Dekkers, Bruxelles, Bruylant, 1982, p. 137, diz que a origem da usucapio de dois anos, no direito arcaico, está na evolução das técnicas agrícolas na Itália dos fins do período régio e início da República, especialmente com a introdução da cultura rotativa bienal (v. literatura citada à p.137, nt. 3). O autor chega a dizer que esse tipo de cultura, juntamento com o emprego do arado, explica a invenção da propriedade quiritária sobre o solo. 
De qualquer modo, os sinais dessa antiga ordem, datando provavelmente deste século, são expressamente mencionados no corpus gromaticus. ${ }^{562}$

Esse regime pressupõe, com efeito, alguns elementos essenciais: a existência de uma antiga ordem augural de divisão do solo; ${ }^{563}$ assignações segundo um modelo quadriculado no qual o todo e as parcelas são idealmente mensurados ${ }^{564}$ - nas palavras de Hygino Gromático, ab hoc exemplo antiqui mensuras agrorum normalibus longitudinis incluserunt -;.565 a presença de um auctor, ou seja, de alguém que realizasse legitimamente e respondesse, em nome do populus, por essa divisio et adsignatio, sem a qual qualquer ato privado de apossamento ou aquisição é ilegítimo, etc.

E qual a relação entre esse regime e o da propriedade quiritária do período pré-clássico? A questão é deveras importante, especialmente do ponto de vista dogmático, de direito privado.

A essência dessa relação está na origem do que hoje entendemos por «propriedade privada» (já no período cívico) ${ }^{566}$ justamente nas primeiras

${ }^{562}$ O próprio Hygino menciona antigas colônias fundadas por reis; os sinais da antiga limitatio incidente sobre esses territórios ainda estavam presentes, embora recortados por novos limites: illas quoque urbes quae deductae a regibus aut dictatoribus fuerant... ideoque multis regionibus antiquae mensurae actus in diversum novis limitibus inciditur (Lachmann 177). Sempre se respeita a vetusta limitação; cf. Lachmann 165: Gracchanorum et Syllanorum limitationum mentio habenda est. In quibusdam enim regionibus, ut opinamur, isdem lapidibus limitibusque manentibus post assignationes posteriores, duces facti sunt. Quibusdam autem, limitibus institutis, alii lapides sunt positi, etiam eis manentibus quos Gracchani aut Syllani posuerunt. De qua re diligenter intuendum erit, ut eos lapides eosque limites conprehendamus, qui postremo per auctorites divisionis positi sunt; e Lachmann 171: perticae fines, hoc est primae adsignationis. Cf. também B. BRUGI, Le dottrine giuridiche degli Agrimensori Romani... cit., p. 240. Citamos mais fontes abaixo, no decorrer da exposição.

563 "Le prische divisioni augurale del suolo» (B. BRUGI, Le dottrine giuridiche degli Agrimensori Romani... cit., p. 118), referida pelo jurista Trebácio em Serv. comment. in Verg. Aen. 11, 316.

${ }^{564}$ Do que não duvida nem o cético B. BRUGI, Le dottrine giuridiche degli Agrimensori Romani... cit., p. 237: "La divisione geometrica del suolo richiede scienza o una pratica tradizionale... pare nondimeno che già le vetuste colonie fossero fondate com rozze limitazioni».

565 In Lachmann 132: «segundo esse padrão, os antigos enclausuraram um espaço delimitado de terra em ângulos retos» (nossa tradução).

${ }^{566}$ Como afirma expressamente BEAUDOUIN, a instituição da limitação de terras é contemporânea ao estabelecimento da propriedade (La limitation des fonds de terre cit., p. 409). Reparo nosso: trata-se apenas da propriedade fundiária pois, como vimos, a propriedade, a manus sobre outras coisas é um fenômeno praticamente impossível de datar.

Poder-se-ia objetar, anacronicamente, que aqui invadimos a seara do «direito público», alheia às nossas preocupações privatísticas. Mas a objeção não faz sentido: é impossível falar sobre o instituto da "propriedade quiritária» e do usucapião ignorando o modo como foi introduzida a propriedade 
assignações pelo rex/magistrado, ${ }^{567}$ provadas amplamente pelas fontes. Cada concessão é, na linguagem do direito clássico, uma divisio e uma adsignatio: um ato originário que cria, no enclausurado ager romanus, um espaço privatus idealmente mensurado (com um modus que deve ser exercido por um usus) e hereditário em favor de uma família. O solo destinado a esse fim chama-se, por esse motivo, ager divisus et adsignatus, em contraste com o ager arcifinius, qui nulla mensura continetur, $^{568}$ em certas circunstâncias objeto de possessio, ${ }^{569}$ mas nunca de propriedade ex iure Quiritium. A idéia mesma de possessio está ligada à ausência de

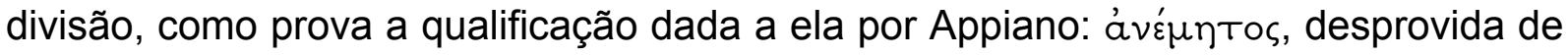
limites ou não distribuída. ${ }^{570}$

fundiária em Roma, e quais os possíveis reflexos dessa ordem original sobre o direito privado. Como disse Gai. 21 ad ed. prov., D. 41, 3, 1: bono publico usucapio introducta est.

567 Segundo a lição de M. KASER, Eigentum und Besitz cit., pp. 228-229, que desenvolvemos no item 4.2, precede a propriedade privada uma "publizistische Herrschaft» (por inadequada que seja a expressão); ou seja, sobre o solo não se dá «private Sachgewalt», como no caso dos bens móveis e pessoas sob domínio direto do pater. Trata-se aqui de uma soberania sobre o solo, "Bodenhoheit», que se inicia com a gens e, no período cívico, passa às mãos do rex, dos seus sucessores republicanos (em última instância o populus Romanus) e respectivos magistrados. O papel do auctor (segundo Festo 79 equivalente ao populus na alienação de um fundus: populus... hoc est auctor) como já entrevíamos, é o de longa manus ou representante da autoridade máxima, mas parte da soberania sobre o solo recai diretamente sobre ele, mesmo como titular desse poder (exemplo de ius procedente dos magistrados, marca dos inícios da República). É dele que procede concretamente a divisio et adsignatio, como prova a denominação posterior auctor divisionis et adsignationis; através de uma analogia com os templa, «clearly and firmly bounded by the actions of the person who created them» (D. J. GoRgola, The Ritual of Centuriation cit., p. 131), aduzimos que os espaços limitados na centuria estavam intimamente vinculados a ele (ao autor da divisão e à sua auctoritas). Os efeitos dessa fórmula são conhecidos: a transformação de parte do ager publicus, limitado apenas exteriormente, em ager privatus, porção de solo auguralmente delimitada e destinada a particulares. Sem a divisio et adsignatio, a aquisição é ilegítima: carece-se da auctoritas do soberano. E assim, após a adsignatio, o proprietário partilha dessa soberania, como vimos acima (cf. também $\mathrm{P}$. FUENTESECA, Trasferimento e 'auctoritas' cit., p. 85, nt. 7: «il dominus quiritario ha un potere piuttosto di natura pubblica (ex iure Quiritium), dunque in funzione di cittadino, quiris», afirmação que consideramos válida para o período decenviral). Não é à toa que, muitas vezes, a noção de auctoritas será equiparada à de dominium, como vimos ao tratar da história da interpretação da regra do ususauctoritas (cf. também P. NoAILLES, Fas et lus cit., p. 227 e ss.).

${ }_{568}$ Front. in Lachmann 5; Agg. Urb. in Lachmann 5: qui et arcifinius et occupatorius nominatur.

${ }^{569}$ Fest.: Possessiones sunt agri late patentes publici privatique quos non mancipatione sed usu tenebant et ut quisque occupaverat possidebat. Cf. J. MARQUARDT, Römische Staatsverwaltung I cit., p. 99-100; M. KASER, Das römische Privatrecht I cit., pp. 140-141: é objeto de possessio, no direito arcaico, o terreno que, não sendo objeto de datio adsignatio em favor de particulares, e permanecendo juridicamente nas mãos do populus Romanus, é posto limitada e temporariamente (ou melhor "wiederruflich», revocavelmente) à disposição de particulares.

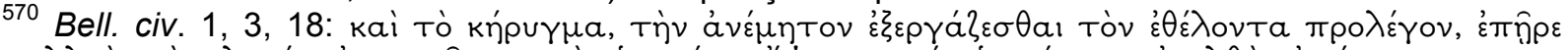

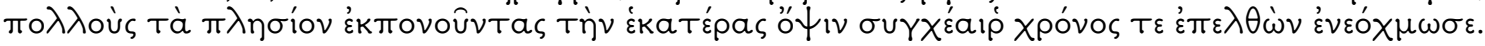


Outro ponto envolve um raciocínio incontroverso: a) um dos modos por excelência de aquisição da propriedade ex iure Quiritium (ainda usamos a linguagem clássica) é o usucapião, instituto que se segue àquele previsto pela regra do usus auctoritas; b) ora, só se permite a aquisição de terra sobre o ager romanus (mais tarde sobre o solo itálico, segundo o ius italicum $)^{571}$ e ainda assim sobre parcelas ideais disponibilizadas à apropriação de particular; c) essas parcelas, por sua vez, foram criadas por uma limitatio, regularmente através de uma centuriatio; ${ }^{572}$ d) logo, o objeto do usucapião é exclusivamente o solo objeto de limitatio, e originalmente, como veremos, segundo um modus.

Isso mostra que é impossível tratar do usucapião - e portanto, com maior razão, da regra do usus auctoritas - e da propriedade quiritária sem mencionar a limitatio, como há muito tempo, aliás, já alertava P. Bonfante. ${ }^{573}$ Mesmo Cícero dá a entender que a limitatio é uma instituição em forte contato com o ius civile..$^{574}$

Ao menos no período pós-decenviral (séc. IV), entretanto, a idéia de um fundus que é meum ex iure Quiritium já se encontra bastante desvinculada da antiga ordem augural de limitação. Isso é resultado da gradual autonomia das terminações privadas e do direito privado em geral a partir do locus-Prinzip, ${ }^{575}$ mas mesmo

571 Tardiamente, o ius italicum previa a «Usucapionsfähigkeit», assim como a alienabilidade por mancipatio, ou seja, a possibilidade de aquisição quiritária, apenas para o solo itálico; desse regime estava excluído o solo provincial, que só podia ser objeto de possessio ou usus fructus. Essa característica é herdada da mesma presumida regra que incidia sobre o ager Romanus (PREMERSTEIN, v. ius italicum in RE, pp. 1238, 1242; v. literatura em M. KASER, Das römische Privarecht I cit., p. 214, nt. 2).

572 Procurar-se-á em vão qualquer referência dos escritores gromáticos a uma terra pública que é ao mesmo tempo limitada através de uma centuriatio, embora haja raríssimas e tardias exceções (BEAUDOUIN, La limitation des fonds de terre cit., p. 456).

${ }^{573}$ Corso di diritto romano II - La proprietà 1, Roma, A. Sampaolesi, 1926, p. 204, citando a limitatio como a primeira característica da propriedade arcaica, e p. 214-215, desenvolvendo o assunto.

574 Depois de utilizar termos como «controversia de finibus», «finis», «termini», «requiri terminos», etc, Cícero põe na boca de Quinto a seguinte declaração: a te verba, usurpantur civilis iuris et legum (de legib. 1, 21, 50). Cf. B. BRUGI, Le dottrine giuridiche degli Agrimensori Romani... cit., p. 119. Paul. 5 ad Sab., D. 18, 6, 7, 1, usa o termo limites para indicar os confins que tangem um fundus, elemento importante na solução de uma controvérsia. Em geral, $O$ Digesto traz inúmeras referências a esse universo gromático, mesmo numa época em que não só a antiga ordem augural, mas também a limitatio do período imperial já vinha há muito tempo perdendo força; por exemplo, Scaevol. 5 dig., D. 13, 7, 43 pr; Javol. 10 ex Cass., D. 8, 3, 13, 2; Flor. 6 inst., D. 41, 1, 16 pr; Ulp. 68 ad Ed., D. 43, 12, 1, 6-7; Ulp. 16 ad Ed., D. 6, 1, 15, 2; Paul. 6 resp., D. 21, 2, 11; Pomp. 36 ad Sab., D. 49, 15, 20, 1; Ulp. 53 ad Ed., D. 39, 3, 1, 23; Callistr. 5 de cogn., D. 47, 21, 3, 2; Mod. 3 diff., D. 7, 4, 21 pr. Cremos que, quando possível, as referências a essa ordem tenham sido eliminadas pelos compiladores.

${ }^{575} \mathrm{~V}$. adiante. 
quando a alienação dos fundi é um fato comum, permanece a regra de que apenas o solo itálico - equivalente tardio do ager romanus -, e não o provincial, pode ser objeto de propriedade quiritária. São restos do antigo regime.

Essa mudança no regime fundiário ocorre em dois planos distintos, mas relacionados. O primeiro plano a considerar é o dos próprios limites: o obscurecimento da antiga ordem augural levado a cabo pelas terminações privadas. O segundo diz respeito ao próprio estatuto jurídico do dominium: a mudança no modo de se garantir a propriedade sobre os fundi e seus respectivos limites. A idéia de usus auctoritas e de usucapio, como veremos, está diretamente involvida nessa transformação.

O primeiro plano dessa mudança foi descrito classicamente por B. BRUGI: «il diritto privato conduceva a spezzare le linee geometriche e i 'termini ufficiali», mediante o fracionamento dos fundi limitados em loca ou particulae ou a sua alienação parcial. ${ }^{576}$

Antes dele, NiebuHr havia esboçado uma teoria diferente: os fundi limitados seriam indivisíveis, e portanto não teria sido possível fracioná-los e alienar algumas das parcelas resultantes. A primeira adsignatio os teria marcado com um modus e as convenções privadas não podiam prevalecer contra ele. ${ }^{577}$

A tese de Niebuhr tem a sua razão de ser. Cremos que a idéia de usus auctoritas representava, mesmo após a edição da lex XII tabulatum, uma força favorável ao reconhecimento jurídico secundum adsignationem, ou seja, à aquisição do usus sobre o fundus concreto nos limites ou modus da adsignatio original, ${ }^{578} \mathrm{em}$ prejuízo das convenções privadas (secundum convenientiam). O efeito jurídico mais importante dessa primeira adsignatio era a impossibilidade de retorno da propriedade ao populus. ${ }^{579}$

Mas essa tendência é combatida no período clássico. E esse constitui o contra-argumento de BRUGI à tese de NIEBUHR. Ele concebe, na história da

\footnotetext{
${ }^{576}$ Le dottrine giuridiche degli Agrimensori Romani... cit., p. 259.

${ }_{577}$ Römische Geschichte II, 3. ${ }^{a}$ ed., Jena, 1834, pp. 708-710.

${ }^{578}$ «Die ursprünglische Gränze begriff wie ein ganzes alles in sich, und alle Theile hafteten für den Modus der ersten Assignation» (idem, p. 710).

${ }^{579}$ Idem, p. 701; com a reserva de que NIEBUHR usa a palavra Staat ao invés de populus.
} 
propriedade romana, duas forças contrárias: a antiga ordem, tendente a conservar as divisões do solo tal como idealmente assignadas, em favor da estabilidade «immutabili patromoni privati scaturiti dal grande patrimonio immobiliare del 'populus'» -, e o direito clássico, que acolhe a nova tendência no sentido de uma propriedade ilimitada do solo e de uma ampla flexibilidade de alienação. ${ }^{580}$

Todavia, a tentativa de reconstrução da condição inicial de um fundus com o reestabelecimento da ordo veteris adsignationis $-{ }^{581}$ não está ausente nos escritos gromáticos, apesar do momento em que foram escritos; ${ }^{582}$ isso prova que, mesmo tardiamente, a antiga ordem augural e as adsignationes ainda produziam efeito na configuração da propriedade e dos seus limites.

A grande vantagem do sistema ideal formado pelas parcelas na centúria é que cada "proprietário» gozava da posse segura de um fundus concreto intimamente atrelado a um modus agri, que compreende o heredium em sentido restritivo - jardim e horto, na teoria mommseniana - e a terra cultivável dele indissociável, que formam uma unidade.

Uma passagem extremamente importante de Sículo Flaco compara o ager occupatorius, destinado à posse revocável, ao ager divisus et adsignatus dizendo que o primeiro nullum est aes, nulla forma, quae publicae fidei possessoribus testimonium reddat, quoniam non ex mensuris actis unus quisque modum accepit. ${ }^{583}$

580 Isso explicaria a natural tendência dos escritores gromáticos de recordar os priscos tempos das assignações em bina iugera e a sua preocupação em salvaguardar o patrimônio do populus (B. BRUGI, Le dottrine giuridiche degli Agrimensori Romani... cit., p. 50-51). Em nossa opinião, é justamente esse tradicionalismo que os torna confiáveis como testemunhas da antiga ordem augural de limitação.

${ }^{581}$ Isso representa, em Frontino, uma restitutio formarum: Convenire autem omnino in restitutione formarum omnia debent, ut secundum signa in formis nominata locus quicumque erat restituatur, aut artificio signorum loca requirantur, si erint, ut frequenter evenit, turbata. Ea docere nos angulorum positiones poterint. Sic erit ut et artis sinceritas servetur et ordo veteris adsignationis non praetermittatur (Lachmann 47-48).

${ }_{582}$ Nos escritos de Nipsus, por exemplo, há um procedimento denominado, não sabemos se formal ou informalmente, limitis repositio (Lachmann 286-295). Através dele, o agrimensor ia até um local assignado da centúria (in agro adsignato) e procurava identificar, pelas pedras terminais (lapides centuriales) e pelos sinais gravados (lege scripturam lapidum; por exemplo, DECIMANVS SEXTVS CARDO XIIII), a sua posição dentro do sistema original de limitação. Analisando o terreno, ele encontrava a forma da centúria, bem como o modus de cada parcela, e podia restaurar a ordem original (Lachmann 295: ad formam revertere).

${ }^{583}$ Lachmann 138. A passagem foi usada por M. WEBER na tentativa de comprovar a sua polêmica tese sobre o alto desenvolvimento, já em época decenviral, da alienação «capitalista» de terras em parcelas idealmente mensuradas através da mancipatio. Não nos interessa, com nosso trabalho, provar qualquer tese sociológica, e nem sequer histórica; toca-nos apenas o direito privado romano. 
Isso nos leva ao segundo plano da mudança: o do estatuto da propriedade. Nessa passagem de Flaco, aduz-se que uma parcela assignada dentro do sistema da centúria (a forma ou carta divisória), parte do antigo sistema de limitação, tem a seu favor um «testemunho de natureza pública» no que diz respeito ao seu modus correspondente e à sua titularidade; como diz M. WEBER, «Gegenstand der Assignation und der öffentlichen Garantie war nur der assignierte modus agri». ${ }^{584} \mathrm{~A}$ linguagem aqui é moderna, mas remete já às primeiras assignações; veremos adiante porquê.

Esse testimonium publicae fidei não diz respeito ao locus, ou seja, a um fundus no sentido determinado, delimitado fisicamente, quase sempre fruto de terminações privadas posteriores à adsignatio (situação descrita por BRUGI, como vimos, como um spezzamento operado pelo direito privado sobre as antigas «divisões geométricas»). Ela assegura, pelo contrário, como decorre do texto mesmo, a medida ideal de uma parcela herdável ligada a uma família: uma concepção claramente arcaica, que remete à idéia do fundus weberiano, o «direito de um cidadão a participar na comunidade», que está à base do suum ex iure Quiritium.

Comparavelmente diferentes são também a antiga regra do usus auctoritas e a usucapio, vigentes respectivamente nos períodos arcaico e clássico.

A regra do usus auctoritas, na sua formulação original, só pode recair, como vimos no primeiro item, sobre solo destinado à aquisição privada; naqueles tempos, tratava-se de parcelas dentro da limitatio ${ }^{585}$ cujo usus fora concedido ex auctoritate ou cuja «propriedade» fora já atribuída a alguém - portanto, sempre solo segundo um modus, antes dos desmembramentos dos fundi em particulae e loca.

Nesse âmbito, seria o «usucapião» decenviral, em termos clássicos, a aquisição do usus fundi segundo um modus, e não de um locus concreto? A pergunta demanda um longo excurso.

Como é fácil perceber, todas as incursões históricas têm como único objetivo contextualizar a interpretação dogmática de um fragmento das XII tábuas, evitando com isso anacronismos e construções jurídicas superficiais.

${ }_{585}^{584}$ Die römische Agrargeschichte... cit., p. 120.

${ }^{585} \mathrm{O}$ usucapio e a limitatio têm, não por acaso, o mesmo fim: evitar controvérsias (cf. Lachmann 121). 
Lembremos que originalmente fundus significa, além do direito a uma quota de participação fundiária (Anteilsrecht), uma medida determinada, embora ideal. ${ }^{586}$ Ele equivalia a meio iugerum ${ }^{587}$ numa centúria, ${ }^{588}$ e, como diz BRUGI com apoio em Frontino, ${ }^{589}$ constituere fundos significava «assegnare terre mediante la limitazione». ${ }^{590}$ Sob a lei das XII tábuas, semelhantemente, fundus designava possivelmente o ager quadratus de dois iugera, ou seja, uma sors dentro da centúria. $^{591}$ (A autonomia do direito privado fará com que fundus perca esse significado no direito clássico). ${ }^{592}$

Mas que a propriedade quiritária resultado da regra do usus auctoritas tenha como objeto precípuo um modus não quer dizer que ela fosse abstrata e incorpórea.

Nossa conclusão baseia-se na história da controversia de modo esboçada por M. WEBER na sua Habilitationschrift, que todavia será parcialmente objeto da nossa crítica mais adiante. Ela parte da idéia que vínhamos reforçando de que o antigo sistema de limitação, fundado no modus-Prinzip, tinha primazia sobre as posteriores demarcações privadas (segundo o raciocínio inafastável de BRUGI e BEHRENDS), e que portanto qualquer tentativa de investigação da pré-história do usucapião deve respeitar essa característica da antiga propriedade fundiária.

Goza de verossimilhança a sua tese sobre o predomínio do modusPrinzip sobre o locus-Prinzip no período arcaico, bem como sobre o equilíbrio de ambos num momento posterior, cuja causa ele atribui, de modo indistinto (sem

\footnotetext{
${ }^{586}$ Essa coincidência de significações - quais sejam, (i) o fundus decenviral como sors, ager quadratus de dois iugera, ou seja, como medida ideal, como veremos abaixo, e (ii) a idéia de fundus como quota de participação na comunidade dos Quirites - só reforça a tese weberiana, como lembrou BRUGI, Le dottrine giuridiche degli Agrimensori Romani... cit., p. 255.

587 Lachmann 30: Ex actibus conicio acnuam primum appllatum, dictum fun|dum. Hi duo fundi iuncti iugerum definiunt. Deinde haec duo iugera iuncta in inum quadratum agrum efficiunt, quod sinte in omnes partes actus bini, in hunc modum. Quidam primum appellatum dicunt sortem, et centies ductum centuriam.

${ }_{588}$ Lachmann 371 : ...agros in centuriis, centurias in iugeribus...

${ }^{589}$ Lachmann 48, 11.

590 Le dottrine giuridiche degli Agrimensori Romani... cit., p. 254; cf. Lachmann 48, 14, onde fundus significa uma parcela delimitada; e Lachmann 313,3 , onde paginae fundorum designam várias parcelas ao menos originalmente enclausuradas em uma limitação.

591 Le dottrine giuridiche degli Agrimensori Romani... cit., p. 254-255.

${ }^{592}$ Idem, p. 255.
} 
reparar que o próprio usucapião foi objeto da mesma transformação), à introdução do instituto do usucapião. ${ }^{593}$

A controversia de modo, na sua visão, é um procedimento gromático que se inicia quando alguém alega que o modus possuído por ele não está de acordo com a forma prevista originalmente no sistema da centúria ou ${ }^{594}$ com a medida a ele transmitida por mancipatio. A sua pretensão é uma revisão da relação fundiária com a conseqüente adsignatio (Zuweisung), em seu favor, do modus na sua integralidade. ${ }^{595}$ Por isso, essa controvérsia só pode ser estabelecida - em oposição à controversia de loco, que tem como objeto principal terra não limitada, ager arcifinius - quando se trata de ager divisus et adsignatus, objeto de propriedade quiritária.

\footnotetext{
${ }^{593}$ Para uma boa introdução a essa difícil questão e ao seu contexto no debate entre os juristas do séc. XIX, v. O artigo de L. CAPOGROSSI COLOGNESI, Le comunità rurali di Roma arcaica nella storiografia del tardo '800, in Studi in Memoria di Giuliana D'Amelio I, Milano, Giuffrè, 1978, pp. 174179, e o capítulo I - La 'Storia agraria romana', la comunità agraria e le forme giuridiche e gromatiche dell'ager Romanus', de Max Weber e le economie del mondo antico, Roma, Laterza, 2000, pp. 3-37. Remetemos também a O. BEHRENDS, Bodenhoheit und Privateigentum... cit., pp. 483-486, para uma crítica - da qual partilhamos - a M. WEBER no que diz respeito à sua tese sobre o modo de alienação de parcelas via mancipatio; v. também M. KASER, Eigentum und Besitz cit., pp. 273-276 e nt. 13 às pp. 275-276; e F. T. HINRICHS, Die Geschichte der gromatischen Institutionen cit., pp. 93-94, nt. 2. A relação, entretanto, entre a tese de WEBER a respeito do modus-Prinzip e do fundus como quota de participação na comunidade agrária e as conclusões de BEHRENDS é de dependência direta. A divergência entre ambos dentro do tema que nos interessa diz respeito ao período histórico em que teria predominado o modus-Prinzip.

${ }^{594} \mathrm{M}$. WEBER parece dizer que se trata de duas condições (pela presença da conjunção aditiva «e» no texto original, que aqui corrigimos para «ou»): "Die controversia de modo entsteht durch die Behauptung einer Partei, daß sie nicht im Besitz des auf Grund der Flurkarte, forma, und der nachweislichen rechtsförmlichen Eigentumsübertragungsakte - insbesondere Manzipationen innerhalb der Flur ihr zustehenden modus sei» (Römische Agrargeschichte cit., p. 162). Na verdade, são duas causas distintas que podem dar origem à controversia de modo: ou se pretende o reestabelecimento com base na lex colonica ou com base na lex contractus, ou seja, na mancipatio, como bem notou A. RUDORFF, Gromatische Institutionen cit., p. 445.

${ }^{595}$ M. WEBER, Die römische Agrargeschichte... cit., p. 162. Compare-se F. T. HINRICHS, Die Geschichte der gromatischen Institutionen cit., pp. 95-99; A. RUDORFF, Gromatische Institutionen cit., pp. 445-447. Cf. Lachmann 13, 1-3: De loco controversia est quom quid excedit supra scriptam latitudinem, cuius modus a petente non proponitur, Lachmann 13-14: De modo controversia est in agro adsignato. Agitur enim de antiquorum nominum propria defensione; Lachmann 14: Nam et in ceteris agris de modo fit controversia, quotiens promissioni modus non quadrat; Lachmann 45: De modo controversia frequenter in agris adsignatis exercetur: agitur enim ut secundum acceptam eius veterani qui in illud solum deductus est, modus restituatur; aut si quando prescriptus est lege aliqua agri modus; Lachmann 131: De modo questiones fere in agris divisis et adsignatis nascuntur, item quaestoriis et vectigalibus subiectis, quoniam scilicet in aere et in scriptura modus conprehensus est. Quod semper erit ad formam; Modest. 11 pandect., D. 10, 1, 7: De modo agrorum arbitri dantur et is qui maiorem locum in territorio habere dicitur ceteris qui minorem locum possident, integrum locum adsignare compellitur: idque ita rescriptum est.
} 
Através dela, em favor do titular do modus, procurava-se reestabelecer os limites antigos (die früheren Grenzen wiederherstellen), ${ }^{596}$ mesmo que isso supusesse uma completa redistribuição das parcelas. Isso nem sempre era possível no tempo dos agrimensores: como indica uma passagem de Frontino, quod autem in adsignato agro secundum formam modus spectetur, solet tempus inspici et agri cultura. Si iam excessit memoriam abalienationis, solet iuris formula [non silenter] intervenire et inhibere mensores, ne tales controversias concipiant, neque quietem tam longae possessionis inrepere sinit. 597

Caso isso aconteça, não é possível dar início ao procedimento de Neuaufteilung, de nova repartição. Uma hipótese a explicar essa impossibilidade seria a vetustas ou auctoritas vetustatis (que os alemães chamam Unvordenklichkeit, intraduzível $)^{598}$ atribuída à posse concorrente, que WEBER erroneamente aceita: ${ }^{599}$ trata-se de um topos entre os juristas clássicos segundo o qual não só a lex ${ }^{600}$ e a natura, ${ }^{601}$ mas também o «tempo que ultrapassa a memória» é capaz de confirmar e proteger uma situação de fato, de certo modo contra o direito civil. Mas aqui se trata de uma iuris formula; e ela não pode ser outra coisa que a usucapio clássica, como precisa D. NöRR, ${ }^{602}$ embora a menção lembre a longi temporis praescriptio. Nesse caso, não se reconhece nenhuma situação de fato excepcional contra o direito civil. $^{603}$

\footnotetext{
${ }^{596}$ Idem, p. 163.

597 Lachmann 45.

${ }^{598}$ Cf. Paul. 49 ad Ed., D. 39, 3, 2, 8: Item Labeo ait, cum quaeritur, an memoria exstet facto opere, non diem et consulem ad liquidum exquirendum, sed sufficere, si quis sciat factum esse, hoc est, si factum esse non ambigatur: nec utique necesse esse superesse qui meminerint, verum etiam si qui audierint eos, qui memoria tenuerint; Lab. 7 pith. ad Paul. epith., D. 22, 3, 28 pr: Si arbiter animadvertere debeat, an operis facti memoria exstet, hoc ei quaerendum est, an aliquis meminerit id opus factum esse. Paulus: immo cum in arbitrio quaeritur, memoria facti operis exstet nec ne, non hoc queritur, num aliquis meminerit, quo die aut quo consule factum sit, sed num hoc aliquo modo probari possit, quando id opus factum sit: et hoc ita, quod Graece dici solet $\dot{\varepsilon} v \pi \lambda a ́ t \varepsilon$. Enim potest hoc memoria non teneri: intra annum puta factum, cum interim nemo sit eorum, qui meminerit, quibus consulibus id viderit, sed cum omnium haec est opinio nec audisse nec vidisse, cum id opus fierit, neque ex eis audisse, qui vidissent aut audissent: et hoc infinite similiter susum versum accidet, cum memoria operis facti non exstaret.

${ }_{599}$ Die römische Agrargeschichte... cit., p. 164.

${ }^{600}$ Ulp. 53 ad Ed., D. 39, 3, 1, 23; Paul. 49 ad Ed., D. 39, 3, 2 pr.

${ }^{601}$ Cf. Hyg. in Lachmann 115, 13-14.

${ }^{602}$ Die Entstehung der longi temporis praescriptio - Studien zum Enfluß der Zeit im Recht und zur Rechtspolitik in der Kaiserzeit, Köln-Opladen, Westdeutscher, 1969, pp. 58-59.

${ }^{603}$ Idem, p. 59.
} 
O que é notável nessa passagem é que ela faz menção, na formulação de WEBER, a uma situação em que o direito a um locus concreto aparece como uma exceção - em posição contrária - à pretensão ao modus, ${ }^{604}$ perdendo esta o seu objeto. Essa possibilidade representaria uma modificação jurídica essencial. ${ }^{605}$

No tempo em que escrevem os agrimensores, o que ocorria, já que quase sempre se mostrava impossível uma reconstituição da forma, era a transformação da pretensão ao modus - quando bem-sucedida - em uma pretensão à condenação em dinheiro contra o vendedor, um aestimatum petere ex forma, ${ }^{606}$ que WEBER julga ser um caso especial da vindicatio. ${ }^{607}$

A pretensão ao modus destinada a uma completa alteração na posse dos confinantes dentro de um sistema de limitação é característica de tempos anteriores, ${ }^{608}$ e portanto do direito arcaico, embora ainda seja mencionada no Digesto como objeto de um arbitrium de modo agri (Modest. 11 pandect., D. 10, 1, 7: integrum locum assignare compellitur).

A origem weberiana da idéia de modus agri, como vínhamos adiantando, está no que ele chama, partindo da conhecida obra de A. MEITZEN, Hufenverfassung, ${ }^{609}$ um sistema de quotas ou direitos de participação (Hufen, Hufenrechten) na comunidade agrária que teria vigido antes das XII tábuas. ${ }^{610} \mathrm{O}$ que fez WEBER, com menos dados do que hoje temos - como vimos neste item, o tema só faz crescer em complexidade quando se penetra no assunto da limitatio, algo que esse autor só fez parcialmente -, foi associar o modus agri ao antigo sistema germânico descrito por MEITZEN e aplicar esse modelo ao antigo significado de

\footnotetext{
${ }^{604}$ Die römische Agrargeschichte... cit., p. 165.

605 Idem, p. 164.

${ }^{606}$ Frontino, in Lachmann 45: secundum formas aestimatum petere.

${ }^{607}$ Die römische Agrargeschichte... cit., p. 166.

608 Idem, p. 170.

${ }^{609}$ De Hufe, que na terminologia weberiana indica uma quota ideal sobre o Dorfmark - a terra «marcada», limitada, ao redor da colônia, e que compreendia uma área compascua, um bosque e um campo arável divido em parcelas iguais (a própria Hufenverfassung em sentido concreto) - a que tinha direito um membro da comunidade agrária segundo o modelo germânico de colonização agrária que WEBER aplica aos primeiros romanos.

${ }^{610}$ Para uma definição bastante exata, cf. L. CAPogrossı ColognesI, Max Weber e le economie del mondo antico cit., p. 433-434.
} 
fundus, ou seja, "direito de participação na comunidade», Genossenrecht ou Hufenrecht. ${ }^{611}$

Weber diz que com base nesse direito cada homem podia reivindicar «judicialmente», após a divisão, a quota que Ihe fora atribuída, em caso de conflito; esse seria o antecedente da vindicatio do fundus entendido como totalidade, ${ }^{612}$ como solo fisicamente delimitado. Com relação à controversia de modo agri, o seu antecedente seria algo semelhante à germânica Gewannregulierung, procedimento equivalente mas sem a relativa sofisticação da forma descrita pelos agrimensores romanos. As duas categorias aqui são (i) o direito a uma quota (exigível pela vindicatio) e (ii) a adsignatio técnica ${ }^{613}$ de uma quota em determinado local segundo o modus previsto no Hufenverfassung (Gewannregulierung/controversia de modo agri). ${ }^{614}$

Esse esquema teria perdido força com a radical transformação da ordem agrária romana a partir do período decenviral. Fundus passa a significar uma terra determinada e a antiga idéia de modus agri é integrada numa pouco efetiva com a ascensão do locus-Prinzip - controversia de modo agri, com a tendência de se converter todas as pretensões ao modus em condenação em dinheiro. ${ }^{615}$

WEBER tem como claro sintoma dessa transformação, como já vimos, a introdução da usucapio. ${ }^{616}$ Mas aqui o autor equivoca-se, segundo pensamos. Em primeiro lugar, porque atribui, ao «usucapião» das XII tábuas, características do usucapião clássico (justa causa/título e entrega da coisa); em segundo, porque

611 É hora de mencionar ipsis litteris o pensamento de WEBER: «Die technische Ausdruck für Genossenrecht ist 'fundus'. Es ist diese Bedeutung des Wortes noch im italischen Bundesrecht haften geblieben. Wenn eine italische Bundestadt einen römischen Gemeindebeschluß bei sich als Gesetz verkündet, so heißt es von ihr: 'fundus fit', d. h. sie tritt als Rechtgenosse bei» (Die römische Agrargeschichte... cit., p. 171). Já comentamos a idéia de fundus fieri muitas vezes. A fonte mencionada por WEBER é Gell. 19, 8, mas acrescentaríamos a definição de Festo de fundus (Fest. 79: Fundus quoque dicitur populus esse rei, [quam] alienat, hoc est auctor), embora ela tenha levado J. MARQUARDT, Römische Staatsverwaltung II cit., p. 52, nt. 3, a identificar erroneamente fundus fieri com auctor fieri (veremos adiante que essa associação é de qualquer modo frutífera).

612 Ulp. 69 ad Ed., D. 50, 16, 60 pr: 'fundus' autem integrum aliquid est.

${ }^{613} \mathrm{~A}$ noção de uma adsignatio rigorosamente técnica, obviamente, só existirá posteriormente, com a especialização do trabalho dos agrimensores.

${ }_{615}^{614}$ Die römische Agrargeschichte... cit., p. 173.

615 Idem, p. 174.

${ }^{616}$ Idem, p. 174-175. 
enfatiza anacronicamente $\mathrm{o}$ in bonis esse ${ }^{617}$ ausente no período decenviral; ${ }^{618} \mathrm{em}$ terceiro lugar, mais importante, porque presume que o usucapião - considerado em sua generalidade, abrangendo a regra do usus auctoritas - fosse uma novidade absoluta introduzida pelas XII tábuas.

Temos várias razões que sustentam uma tese contrária a essa última afirmação de WEBER - o usucapião como «prinzipielle Durchbrechung der älteren Agrarverfassung»,$-{ }^{619}$ pensando especialmente nesse terceiro ponto: a) a lei das XII tábuas, como compilação e fixação de costumes já existentes, apenas tornaram lei a regra do usus auctoritas, provavelmente introduzindo tão-somente o prazo de dois anos; b) o instituto que nos foi legado com o nome de usucapio pro herede é certamente mais antigo do que as XII tábuas, como o próprio WEBER parece reconhecer, e fornece provas seguras a favor do "usucapio» a partir de um modus, ou seja, do Hufenrecht como um todo; c) a regra do usus auctoritas tal como interpretada pelos pontífices possivelmente passou a incidir, após o período decenviral, sobre o fundus concreto (o que significa que WEBER teria acertado ao projetar sobre o usucapião a idéia de ascensão do locus-Prinzip e errado ao não aventar a possibilidade de que o usucapião do qual falava era simplesmente uma transformação da regra do usus auctoritas em usucapio de um locus).

Analisemos cada um desses pontos.

T. MAYER-MALY ${ }^{620}$ e M. KASER, ${ }^{621}$ comprometidos com a teoria da auctoritas-Haftung, cujas bases demonstramos ser, ao menos para o período decenviral, passíveis de ataque, e fixando-se nessa nova interpretação (que prefere confiar em Plauto, como já dissemos), chegaram ao ponto de excluir da regra do usus auctoritas a função de aquisição da propriedade. Tal conclusão parece-nos

617 Um dos elementos da distinção clássica, eliminada formalmente no direito justinianeu, entre

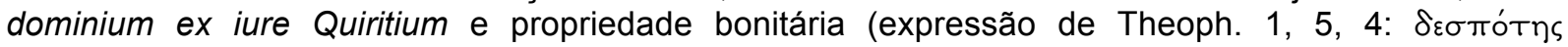
Bovitáplos), ausente no período anterior (cf. Gai 1, 54; 2, 40; 1, 35; 2, 88;). In bonis esse ou habere (ou originalmente res in bona mea) possui o sentido técnico de propriedade lato sensu de uma coisa apoiada em proteção pretoriana via actio Publiciana, normalmente uma res mancipi recebida em traditio (W. KUNKEL/T. MAYER-MALY, Römisches Recht cit., pp. 147-149; M. KASER, In bonis esse, in SZ 78 (1961), pp. 173-220).

618 Ele menciona o antigo Edito reconstruído por O. LENEL

619 Idem, p. 184.

620 Studien zur Frühgeschichte der usucapio // cit., p. 224.

${ }^{621}$ Eigentum und Besitz cit., p. 87. 
ilegítima, por afastar justamente a interpretação de Cícero, que nos legou - como o próprio MAYER-MALY reconhece ao afirmar que esse autor teria conservado o «Originaltext» do respectivo fragmento das XII tábuas $-{ }^{622}$ a fonte primária dessa regra decenviral, apresentando-a explicitamente como antecedente da usucapio imobiliária (a usucapio de móveis - simplesmente denominada usus nas XII tábuas está desvinculada da auctoritas). A conjugação deste testemunho com o de Gaio não admite dúvidas. ${ }^{623}$

A presença de uma norma com função próxima à da usucapio nas XII tábuas é, portanto, inafastável. Já a vigência de um instituto semelhante antes dessa legislação é um fato talvez menos seguro do ponto de vista documental; mas, como já deixamos esboçado, a regra do usus auctoritas é apenas a fixação de um direito pré-existente. Com dificuldade encontrar-se-á uma única norma nas XII tábuas que seja uma novidade absoluta. ${ }^{624}$

Certo raciocínio de Dionísio pode nos ajudar a fixar esse ponto. O historiador menciona que a IV ${ }^{a}$ tábua continha a mesma regra (IV, 2: SI PATER <TER> FILIUM VENUM D $\{A\} V I T$, FILIUS A PATRE LIBER ESTO) ${ }^{625}$ de uma antiga lei de Rômulo हi'T

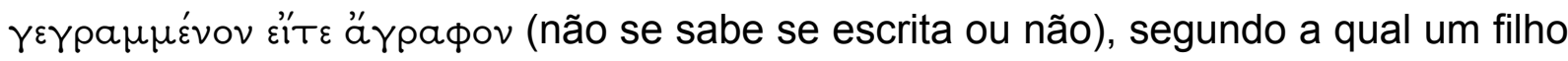

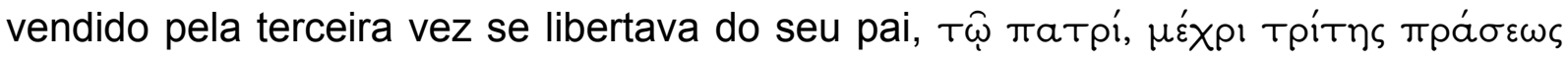

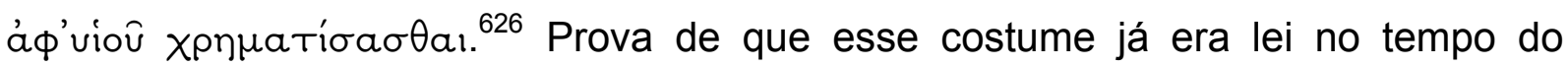
sucessor de Rômulo, Numa Pompílio, é que uma lei deste último pressupõe a vigência daquela atribuída ao primeiro; ela diz que, se um pai permite a um filho

${ }^{622}$ Studien zur Frühgeschichte der usucapio II cit., p. 223.

${ }^{623}$ Gai. 2, 54: lex enim XII tabularum soli quidem res biennio usucapio jussit. Que outra saída temos além de confiar em Gaio, que afirma a existência de uma usucapio bienal presente nas XII tábuas, cuja associação com a regra do usus auctoritas é absolutamente evidente?

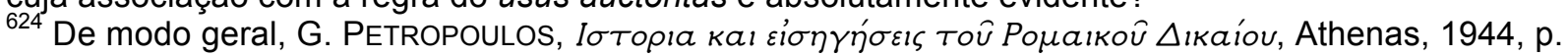
104, afirma que a lex XII tabularum é o resultado de uma maturação da sabedoria jurídica dos antigos romanos. Os clássicos M. VOIGT, Geschichte und allgemeine juristische Lehrbegriffe der XII Tafeln I cit., pp. 6-7; E. TÄUBLER, Untersuchungen zur Geschichte des Decemvirats und der Zwölftafeln, Berlin, E. Ebering, 1921, pp. 117-123; e L. WENGER, Quellen des römischen Rechts cit., p. 358-359 («schriftliche Fixierung des Rechts») não deixam dúvidas de que o objetivo da legislação decenviral era assegurar um direito já existente, restando pouco espaço para a inovação. P.-F. GIRARD, Manuel élémentaire de droit romain cit., p. 28, vai mais longe, afirmando que muito pouco nas XII tábuas se afasta do direito que já estava vigente. Cf. Cic. De or. 1, 193: ...et in xii tabulis antiquitatis effigies, quod et verborum vetustas prisca cognoscitur et actionum genera quaedam maiorum consuetudinem vitamque declarant.

${ }^{625}$ Fontes principais: Gai. 1, 132; Ulp. Reg. 10, 1.

${ }^{626}$ Dion. Hal. 2, 27, 1. 


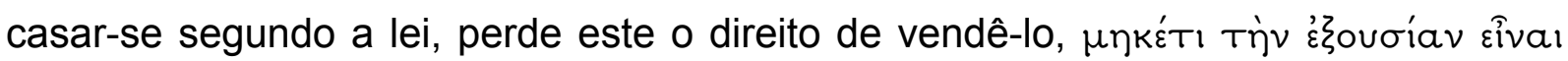

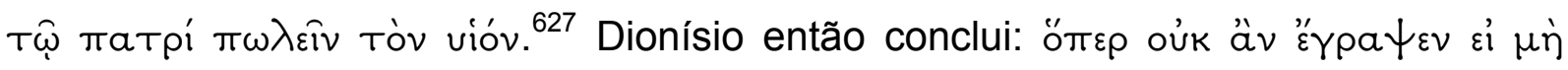

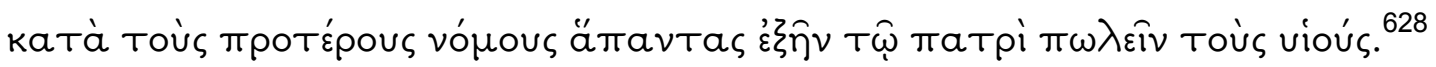

Dionísio diz ainda, com efeito, que a lei das XII tábuas foi elaborada com base em apenas duas categorias de fontes: (i) costumes ancestrais e leis

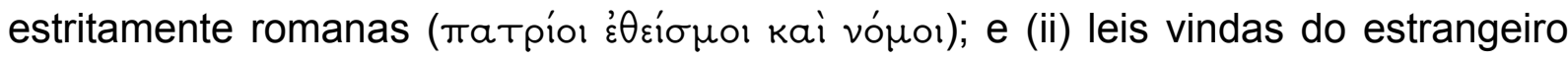

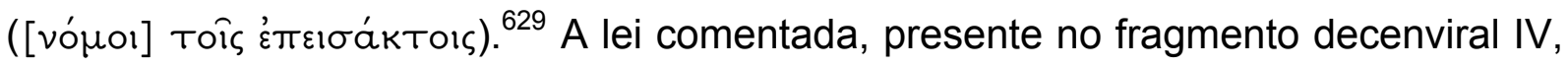
2, insere-se claramente na primeira categoria. A julgar pela passagem de Dionísio, portanto, as XII tábuas não trazem nenhum novo instituto - a não ser que por «novo instituto» se entenda uma regra de direito estrangeira.

Considere-se ainda que certa regra decenviral pressupõe de modo especial a pré-existência da usucapio. Trata-se da proibição de se usucapir a área correspondente ao confinium de 5 pés entre um imóvel e outro (Charondas: INTER CONFINES AGROS V. PEDUM AETERNA AUCTORITAS ESTO; Hoffmann: INTRA V. PEDES USUS AUCTORITAS NE ESTO); ${ }^{630}$ se o problema pressuposto por essa norma essencialmente um problema relativo à limitatio e ao usus - não fosse algo comum no período anterior, ele não teria sido objeto de regulamentação. Uma regra jurídica abstrata, desvinculada de um longo período de experiência, é impensável, especialmente no direito decenviral.

Disso se conclui que a regra do usus auctoritas, antecedente da usucapio imobiliária, entrou na compilação como um instituto já existente - e provavelmente elaborado pelos romanos (mesmo que de raiz pré-romana), e não

\footnotetext{
${ }^{627}$ Dion. Hal. 2, 27, 4.

${ }^{628}$ "Ele nunca escreveria [essa lei] se o pai não tivesse sido autorizado por todas as leis anteriores a vender os seus filhos» (Dion. Hal. 2, 27, 4).

${ }^{629}$ Dion. Hal. 2, 27, 3. M. VoIGT, Geschichte und allgemeine juristische Lehrbegriffe der XII Tafeln I cit., p. 6, engana-se ao descrever essa categoria como um «direito introduzido através de novas regras»; não se trata de neue Satzungen, mas de regras de direito já usadas por outros povos. Repare-se

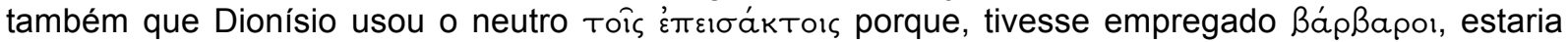
introduzindo erroneamente um conceito que só faz sentido no contexto da relação dos próprios gregos com os estrangeiros (originalmente aos medos e persas: Aesch. Pers. 255, Herod. 1, 58; cf. H. G. LIDDELL - R. SCOTT, A Greek-English Lexicon cit., p. 312), nunca aplicável abstratamente a outros povos na sua relação com os «de fora».

${ }^{630}$ H. E. DIRKSEN, Übersicht der bisherigen Versuche zur Kritik und Herstellung des Textes der ZwölfTafel-Fragmente cit., p. 480. As reconstruções citadas partem do texto de Cícero na Tab. VII, 4a-5a: quorum usus capionem duodecim tabulae int $\{e\} r<a>$ quinque pedes esse $\{v\}<n>0 / u e r u n t$.
} 
pelos gregos. ${ }^{631}$ Por isso o próprio MAYER-MALY reconhece - todavia errando ao dissociá-lo da regra do usus auctoritas - que a usucapio foi recebida pela legislação decenviral como um instituto já consolidado. ${ }^{632}$ F. LEIFER, por sua vez, defendeu explicitamente a pré-existência da própria regra do usus auctoritas à legislação decenviral. ${ }^{633}$

A usucapio clássica é, em sua essência, a aquisição da posição de domínio pela posse contínua (Ulp. Reg. 19, 8: usucapio est dominii adeptio per continuationem possessionem). No contexto arcaico, a «propriedade imobiliária» estava restrita a uma adsignatio original segundo um modus. O usucapião arcaico será, portanto, algo semelhante a uma aquisição do usus - certamente ligada a fatores bastante concretos, como a cultura rotativa - com base num pré-existente título sobre um modus agri, mesmo que anteriormente concedido a outrem.

A usucapio pro herede parece remeter a um esquema semelhante, e isso por dois motivos: (i) por sua provável relação com o heredium, que possuía um modus determinado, e (ii) por envolver uma substituição na posição de domínio do proprietário anterior (uma entrada na cadeia de domínio).

A julgar pela palavra pré-grega eredes, usada pelos sículos, presente numa inscrição do segundo milênio a.C, que seria antecessora do latim heredes, ${ }^{634} 0$ heredium é seguramente muito mais antigo do que as XII tábuas. ${ }^{635}$ Se isso é

631 Há uma literatura específica a respeito das relações entre a longi temporis praescriptio e a

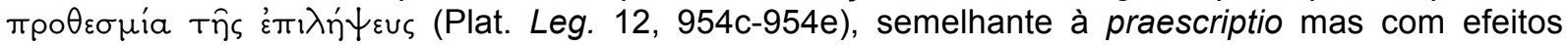
processuais, sem o condão de causar efeitos de direito material (W. KUNKEL/T. MAYER-MALY, Römisches Recht cit., p. 172, nt. 5), e ela resume-se praticamente ao artigo de H. J. WoLfF,

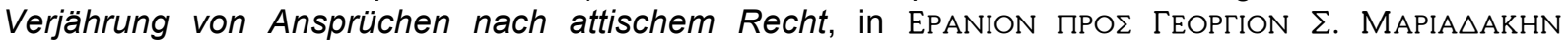

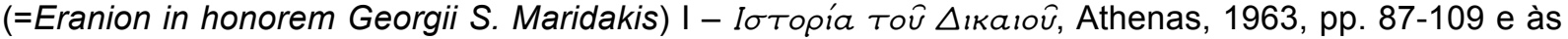
poucas obras de caráter geral citadas à p. 87, nt. 1. No mesmo sentido é D. NÖRR, Die Entstehung der

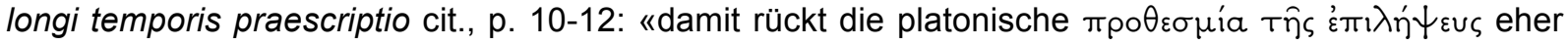
an die prozessual gedachte Itp als an die usucapio heran». Não há qualquer sinal de um instituto correspondente à usucapio entre os gregos ou antigos germânicos (W. KUNKEL/T. MAYER-MALY, Römisches Recht cit., p. 172: «keine echte Entsprechung»); todavia, uma uma figura semelhante à usucapio pro herede pode ser encontrada no direito cuneiforme.

${ }_{632}$ Studien zur Frühgeschichte der usucapio I, in SZ 77 (1960), p. 34.

${ }^{633}$ Mancipium und auctoritas cit., p. 133-134. Mais adiante, discutimos, indicando lit., a pré-existência da usucapio pro herede, ou de seu antecessor, à lei das XII tábuas.

${ }^{634} \mathrm{Cf}$. a lit. apontada e a investigação de H. KAUFMANN, Die altrömische Miete - Ihre Zusammenhänge mit Gesellschaft, Wirtschaft und staatlicher Vermögensverwaltung, Köln-Graz, Böhlau, 1964, pp. 115, nt. 578, e 112-118.

${ }^{635}$ Essa é a também a opinião de M. KASER, Eigentum und Besitz cit., p. 235. 
verdade, o esquema pré-cívico de aquisição do heredium que estaria à raiz da usucapio pro herede ${ }^{636}$ precederia inclusive o sistema de limitação augural do séc. $\mathrm{VI}$, e portanto deveria ser encarado como uma espécie de pré-história, ou ao menos como um caso especial, do usus auctoritas (pré-)decenviral.

Esse sistema pré-cívico supõe, como já aventávamos, a presença de um solo gentílico, antecedente do ager publicus, destinado à agricultura e ao uso comum pelas famílias. É muito provável que, mesmo nessa época, ao lado desse desfrutamento (usus) comum do solo sob a soberania da gens, houvesse espaço para a propriedade individual da casa e do horto, ${ }^{637}$ e também de uma parcela arável, como sustenta U. VON LÜBTOW ${ }^{638}$ (segundo a hipótese levantada por KASER, segundo o princípio superficies solo cedit). ${ }^{639}$

Em linhas gerais, de acordo com o pensamento de MAYER-MALY, ${ }^{640}$ seriam muitos os argumentos em favor de uma conexão direta entre o heredium e a usucapio pro herede, e que o levaram a afirmar que este é o modo mais antigo de usucapião entre os romanos. ${ }^{641}$

${ }^{636}$ Não necessariamente a própria usucapio pro herede, que pode ter sido uma criação da jurisprudência dos pontífices, se damos crédito a Gai. 2, 55: Quare autem omnino tam improba possessio et usucapio concessa sit, illa ratio est, quod voluerunt veteres maturius hereditates adiri. A passagem indicaria, com o uso da palavra veteres, que se trata dos pontífices, como infere G. FRACIOSI, Usucapio pro herede - Contributo allo studio dell'antica hereditas, Napoli, Jovene, 1965, p. 17. Não é improvável, entretanto, que veteres fossem antepassados (maiores) do tempo prédecenviral, como indica a própria legenda do heredium (assim T. MAYER-MALY, Studien zur Elementarliteratur über die usucapio, in Studi Betti III (1962) p. 491: «Die Nachrichten über eine Zuteilung solchen Erbguts... weisen auf die Bedeutung des Begriffs im vordezemviralen Recht hin»). P. BONFANTE, Corso di diritto romano VI - Le successioni, parte generale, Milano, Giuffrè, 1974, pp. 280283 (pp. 226-228 na edição original), afasta a notícia de Gaio e supõe, apesar do mistério que cerca esse instituto, que ele teria uma origem pré-decenviral; no mesmo sentido, U. VON LÜBTOW, Die Entwicklungsgeschichtlichen Grundlagen des römischen Erbrechts, in Studi De Francisci I (1956), p. 470: "die usucapio pro herede [hat] schon vor dem Gesetz [der XII Tafeln] existiert». Contra, especialmente S. SolAzZI, Diritto ereditario romano I, 1932, p. 62, nt. 1, que supõe que veteres fossem juristas republicanos posteriores às XII tábuas, e COLLINET, Les variations de l'usucapion 'pro herede' avant Hadrien, in Studi Riccobono IV (1936), p. 141, vai mais longe ao afirmar que ele teria sido introduzido entre a segunda metade do séc. VI e o séc. VII depois da fundação de Roma (anteriormente ao ano 130 a.C).

${ }^{637}$ P. DE FRANCISCI, II trasferimento della proprietà - Storia e critica di uma dottrina, Padova, Ed. Univ., 1924, p. 56.

${ }^{638}$ Die Entwicklungsgeschichtlichen Grundlagen des römischen Erbrechts cit., p. 411.

639 Eigentum und Besitz cit., p. 237, nt. 29. Sobre o princípio superficies solo cedit, e desenvolvimentos, cf., em nossa literatura, E. C. SILVEIRA MARCHI, A Propriedade Horizontal no Direito Romano, 2. ed., São Paulo, Quartier Latin, 2003.

${ }^{640}$ Studien zur Frühgeschichte der Usucapio I cit., pp. 40-51.

${ }^{641}$ Idem, p. 51. 
Ele imagina a pergunta que se colocaria no momento em que o "proprietário» de um heredium tivesse morrido: voltaria este à gens ou ficaria à disposição de um heres? A resposta é que, provavelmente, quem tivesse adquirido (capio) o usus do heredium seria considerado heres; caso não houvesse nenhum pretendente nessa situação, o heredium voltaria à gens. Futuramente, o conflito entre vários candidatos a heres teria levado a se considerar a duração da posse como elemento crucial para a solução jurídica da questão. ${ }^{642}$

Dentro do esquema que apresentamos, essa situação é plenamente possível. O modus agri concedido a uma família ut heredes sequerentur é destinado a ser, segundo o relato de Varr. re. rust. 1, 10, 2, ao menos transmitido a um heres, sob pena de ficar no vazio. E nesse sentido, uma "volta» do heredium à gens significa apenas que aquele direito ou título desaparece - o que é fruto de uma concepção totalmente diferente de propriedade imobiliária (direito de participação ou poder partilhado de soberania, e não dominium sobre um fundus fisicamente delimitado). ${ }^{643}$ Já na primeira alternativa, a titularidade sobre o modus transmite-se a quem, depois da morte do pater, deu continuidade ao usus sobre a parcela correspondente a essa medida ideal - provavelmente já demarcada e consagrada a Terminus - e portanto é considerado apto a herdar. ${ }^{644}$

Aparentemente contradiz essa idéia a importante constatação de J. $\mathrm{N}$. LAMBERT, em consonância com o que vimos desenvolvendo, de que o heredium era, a princípio, o direito de todo cidadão livre a uma parcela de terra indeterminada (na

\footnotetext{
${ }^{642}$ No que segue a interessante idéia - coerente, a propósito, com a nossa tese - de um possível usucapião sem prazo, sustentada especialmente por F. LEIFER, Mancipium und auctoritas... cit., p. 138 , nt. 1 , e lit. citada.

${ }^{643}$ Críticas apressadas a essa idéia de participação segundo um modus agri normalmente não levam em consideração o fato de que essa prática era comum na Antigüidade, e não produto da imaginação de historiadores e juristas; basta considerar o exemplo das Ancient Laws of Wales lembrado por LAMBERT (cit. em nota abaixo): segundo o costume, cada galês livre tinha direito a 5 jeiras (erw) de terra, uma medida abstrata, portanto um modus agri (cf. H. LEWIS, The Ancient Laws of Wales Viewed Especially in Regard to the Light they Throw upon the Origin of Some English Institutions, London, 1889, p. 121; e os numerosos exemplos em H. SUMNER MAINE, Études sur l'histoire du droit, Paris, E. Thorin, 1889, pp. 88-136).

${ }^{644}$ Isso explicaria porque a manus não se aplica inicialmente ao fundus: não se trata de um poder fático sobre coisas tangíveis, mas de uma participação na soberania da gens, como definimos ao final do segundo item (embora a rigor nossa definição se referisse ao período pós-fundacional e à comunidade dos Quirites da civitas em formação). Mais uma vez a citada passagem de Cícero (pro Caec. 74) parece um eco do antigo direito: fundus a patre relinqui potest, at usucapio fundi..., rata auctoritas harum omnium rerum ab iure civilii sumitur.
} 
linguagem que aqui usamos, um modus agri), ou seja, independentemente do seu local. ${ }^{645}$

Pensamos, todavia, que essa indeterminação era relativa: o sistema convivia com uma imediata individualização e demarcação do terreno correspondente ao heredium, embora o direito que o garantisse tivesse como objeto precípuo uma medida ideal, uma quota de participação (fundus) que podia ser remanejada. Por isso o modus agri podia ser «possuído», ${ }^{646}$ ou melhor, exercido; não em si mesmo, mas sob a forma de um terreno demarcado segundo a medida ideal da adsignatio (no período pré-cívico provavelmente segundo a quota de participação costumeira, atribuída a todo cidadão livre).

Definiremos todos esses pontos no último capítulo, descrevendo, de acordo com as fontes e teorias estudadas neste capítulo, o mais provável modo de aquisição por «usucapião» conforme o período correspondente: pré-cívivico, fundacional e decenviral.

\subsection{Exegese das fontes da auctoritas decenviral}

Nossa hipótese sobre a regra do usus auctoritas, de acordo com os resultados da pesquisa histórico-dogmática dos itens anteriores, sustenta-se em fontes que dividiremos em dois grupos.

Um deles é formado por citações ou paráfrases das XII tábuas, conforme o testemunho de Cícero, Teófilo, Gaio e Boécio, e pela lex Atinia, mencionada por Aulo Gélio e Cícero; ${ }^{647}$ e outro, muito menos importante, considerado aqui para refutar as teses garantistas, por algumas passagens de

${ }^{645}$ Les origines de Rome à la lumière du droit comparè, in Studi De Francisci I, Milano, Giuffrè, 1956, p. 348. O autor também aproxima o heredium do Hufenrecht germânico, «l'unité foncière toujours rigoureusement égale à elle-même et censée suffisante pour faire vivre une famille», e chama «mystique» à participação do cidadão na comunidade agrária (p. 349), chegando ao ponto de afirmar que essa parcela consistente num praedium parvulum seria a fonte de toda a história, exterior e interior, de Roma (p. 350).

${ }^{646}$ Colum. De re rust. 1, 3, 11: quod agri modum... immodica possidendi libidine transcendisset.

${ }^{647}$ Cic. top. 4, 23; Cic. pro Caec. 19, 54; Gai. 2, 42; Gai. 2, 54; Gai. 2, 204; Teoph. 2, 6; Boeth. coment. Cic. top. 4, 23 (ed. Orellius, p. 308); Gell. 17, 7; Cic. de off. 1, 12, 37. Incluímos passagens relativas ao usucapião pelo fato de estarem ligadas, mesmo indiretamente, ao debate sobre a auctoritas, embora algumas delas sejam pouco citadas pelos autores da tese "garantista». 
Plauto; ${ }^{648}$ outros grupos de fontes, formados por fontes jurídicas de Paulo, Ulpiano, Venuleio, Scaevola e Papiniano ${ }^{649}$ e por uma miscelânea de fragmentos literários ${ }^{650}$ não serão investigados aqui, por terem sido examinados anteriormente (e em razão das conclusões dos itens anteriores, que excluem da nossa pesquisa a interpretação da auctoritas como garantia).

A fim de tornar a análise mais clara, transcreveremos e daremos a tradução ${ }^{651}$ das fontes mais importantes de cada grupo.

O primeiro grupo consiste nas seguintes:

Cic. top. 4,23

Quoniam usus auctoritas fundi biennium est, sit etiam aedium; at in lege aedes non appellantur et sunt ceterarum rerum omnium, quarum annuus est usus.

Cic. pro Caec. 19, 54

Lex usum et auctoritatem fundi iubet esse biennium; at utimur eodem iure in aedibus, quae in lege non appellantur.

Gai. 2, 42

...mobilium quidem rerum anno completur, fundi vero et aedium biennio; et ita lege XII tabularum cautum est.
Pois o usus-auctoritas do imóvel é de dois anos, o mesmo quanto ao edifício, embora a lei não se refira a ele; e há as demais coisas, cujo usus é de um ano.

\begin{abstract}
A lei prescreve que o usus e a auctoritas do imóvel é de dois anos; mas aplicamos o mesmo direito aos edifícios, que não são mencionados na lei.
\end{abstract}

...[de] tais coisas móveis se completa em um ano, e dos imóveis em dois; assim previa-se na lei das XII tábuas.

\footnotetext{
${ }^{648}$ Especialmente Poen. 1, 1, 145; Curc. 4, 2, 490; e Trin. 1, 2, 217.

${ }^{649}$ PS. 2, 17, 1-3; Ulp. 30 ad ed., D. 21, 2, 4 pr; Venul. 17 stipul., D. 21, 2, 76; Scaevol. 5 dig., D. 13, 7, 43 pr; Pap. Vat. 10.

650 Val. Prob. 4, 7; Fest. 165; Cic. de harusp. 7, 14; Cic. de off. 3, 16, 65; Cic. top. 10, 45; Cic. pro Mur. 2, 3; 26, 20; 12, 26; Cic. pro Caec. 19, 54; 26, 74; Sen. controv. 7, 6, 22; Sen. nat. quaest. 4, 3, 2; Varr. re rust. 2, 10, 5; Varr. de ling. lat. 7, 105.

${ }^{651}$ Optamos por uma tradução segundo a tradição, mantendo os termos-chave no original e evitando assim adotar, por hora, uma posição. Como se verá adiante, algumas dessas traduções - que seguem o entendimento da doutrina tradicional - terão de sofrer alguma alteração em virtude da nossa exegese. Traduzimos apenas essas fontes porque são de importância crucial para os resultados da pesquisa; as demais fontes latinas não serão acompanhadas de tradução, por secundárias, embora tenhamos traduzido as gregas, em virtude do natural desconhecimento da língua por uma parte da comunidade acadêmica.
} 
Gai. 2, 204

Completur autem usucapio, sicut alio quoque loco diximus, mobilium quidem rerum anno, earum vero, quae solo tenetur, biennio.

Gai. 2, 54

Lex enim XII tabularum soli quidem res biennio usucapi iussit, ceteras vero anno.

Teoph. 2, 6

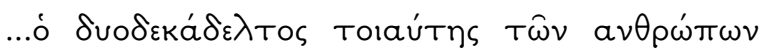

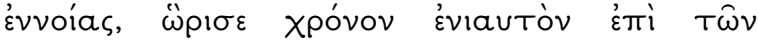

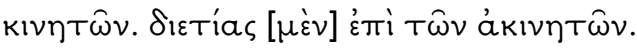

Boeth. comment. in Cic. top. 4, 23

Ita namque ait, ut quoniam usus auctoritas fundi biennium est, sit etiam aedium. Hic igitur aedium usus auctoritatem biennio fieri sentit...

Gell. 17, 7

Verba haec ex Atinia lege: 'quod subruptum erit, eius rei aeterna auctoritas esto'.

Gai. 2, 45

Furtivam lex XII tab. usucapi prohibet.

Cic. de off. 1, 12, 37

Indicant duodecim tabulae: ...adversus hostem aeterna auctoritas.
O usucapião dos móveis se completa, como dissemos alhures, em um ano, e em dois anos o das coisas que se mantêm no solo.

A lei das XII tábuas ordenou que a coisa de raiz fosse "usucapida» em dois anos, e as demais em um.

[o legislador] estatuiu claramente na lei das XII tábuas que [o usucapião] das coisas móveis é de um ano, e o das coisas imóveis de dois.

Assim diz [Cícero] que, sendo o usus auctoritas do imóvel de dois anos, o mesmo vale para o edifício. $\mathrm{Na}$ verdade, julga que a auctoritas provinda do usus dos edifícios se perfaz em dois anos...

Eis as palavras da lei Atinia: 'por ter sido furtada, a auctoritas dessa [sobre essa] coisa é eterna'.

A lei das XII tábuas proíbe o usucapião de [coisa] furtada.

Revelam as doze tábuas: ...diante do estrangeiro, a auctoritas [dos Quirites] permanece para sempre. 
Este primeiro grupo, segundo a interpretação de escritores e juristas da época clássica, refere-se exclusivamente ao usucapião; usus-auctoritas foi simplesmente traduzido por usucapio, e aeterna auctoritas, ao que tudo indica, por proibição de usucapir (usucapi... prohibet).

A exegese apresenta alguns problemas. Há uma chance de que a norma das XII tábuas não contivesse exatamente essas palavras (usus auctoritas fundi biennium est), o que demanda uma breve investigação. À primeira vista, nada impediria, ainda, que o conteúdo da norma das XII tábuas tivesse sido reinterpretado. Essa possibilidade é desprezada tacitamente pelos autores. ${ }^{652}$ Parecenos, todavia, que o que foi transmitido é, senão uma paráfrase, ao menos uma atualização ortográfica da dicção original das XII tábuas. ${ }^{653}$ A expressão usus auctoritas não ocorre em nenhum escrito conservado ou citado antes do séc. I d.C.; trata-se praticamente de um hapax legomenon, já que apenas Cícero se refere a ela; ${ }^{654}$ Boécio está apenas a comentar o seu texto. ${ }^{655}$ Já o termo isolado auctoritas

${ }^{652}$ Embora não seja novidade para a romanística o estudo filológico e epigráfico com finalidade de reconstrução; basta observar a metodologia de MOMMSEN, RICCOBONO, GIRARD, LEIFER e muitos outros, que se dedicaram à epigrafia e aos seus aportes para o direito romano. Cf. a exemplo disso o estudo de F. LeIFER, Zum Problem der Foruminschrift unter dem Lapis Niger: Zwei neue Lösungsvorschläge, Aalen, Scientia, 1963.

${ }^{653} \mathrm{O}$ questionamento primordial refere-se à autenticidade das XII tábuas, e à sua datação no séc. V a.C., segundo a tradição romana (Cic. de rep. 2, 36-37; Liv. 3, 33-34; Dion. Hal. 10, 1-60; Pomp. enchir., D. 1, 2, 2, 24); apenas para um esboço histórico do surgimento da questão (séc. XIX e início do XX), lembramos que o questionamento foi feito de modo radical por E. PAIS, Storia di Roma I, Torino, Carlo Clausen, 1898, mas obteve respostas desde então negativas por parte da crítica, que alegou falta de evidências (cf. A. S. WILKINS, Review: Pais's 'Storia di Roma', in Classical Review $12^{8}$ (1898), p. 421). Também E. LAMBERT, La question de l'authenticité des XII tables et les 'Annales maximi', in NRH 26 (1902), pp. 143-200, tentou combater a tese da autenticidade da legislação decenviral, concordando em parte com E. PAIS - que diz que a compilação seria resultado de um esforço de secularização da jurisprudência pontifícia levado a cabo nos sécs. IV-III aC - mas propondo uma solução diversa. Esses dois autores fizeram escola. Logo em seguida, A. H. J. GREENIDGE, The Authenticity of the Twelve Tables, in The English Historical Review vol. $20, \mathrm{n} .{ }^{\circ} 77$ (1905), p. 21, levantou sérias dúvidas, após uma análise detalhada dos argumentos de LAMBERT e PAIS, sobre a emergente escola crítica - toda ela baseada numa suposta fraude levada a cabo por Aelius Paetus, o mais antigo comentador das XII tábuas ou, no caso de PAIS, por Cn. Flavius, escriba do suposto pontífice Appius Claudius (cf. CIL I 585; cf. também a crítica de A. Zocco-RosA, Per Appius Claudius e per l'lus Flavianum, in SZ 33 (1912), pp. 491-493, que julga não existir nenhuma prova de que Appius Claudius tivesse sido pontífice). No mesmo sentido, O. LENEL, SZ 26 (1905), pp. 498-524. Cf. também a crítica de P. F. GIRARD, L'histoire des XII tables, in NRH 26 (1902), p. 386, favorável à autenticidade das XII tábuas. Essa posição tradicional se mantém até hoje como a mais verossímil.

${ }^{654}$ Nesse sentido, R. YARON, Reflections on usucapio cit., p. 201.

655 Uma interpretação bastante cética seria no sentido de que «usus auctoritas» é uma expressão ciceroniana; apenas um tardio Boécio a mencionou, todavia transcrevendo Cícero. A vasta literatura 
ocorre uma única vez nas XII tábuas, no adágio que supostamente proíbe o usucapião para estrangeiros.

Entretanto, provavelmente todas as palavras da frase conservada por Cícero - usus, auctoritas, fundi, biennium - faziam parte do léxico latino do séc. $V$, embora não ocorram, com exceção de auctoritas e fundus, nos fragmentos decenvirais que constituem uma citação aparentemente literal. ${ }^{656}$

Gaio teria conhecido o texto, ${ }^{657}$ e talvez o tivesse glosado no seu comentário em seis livros Ad legem duodecim tabularum. ${ }^{658} \mathrm{E}$ quiçá teria consultado os comentários de Sextus Aelius, ${ }^{659}$ herdeiro já de uma tradição exegética de séculos, se julgamos superada a questão da cronologia envolvendo o «código» decenviral.

sobre o assunto, entretanto, sequer menciona essa possibilidade; cremos que a ausência desse questionamento demonstra uma certa despreocupação por parte dos autores. Mas trata-se de uma hipótese importante: a sua confirmação - quiçá impossível - seria suficiente para dissociar, em parte, o problema do "usus auctoritas» (ligado à história do usucapião) da noção de garantia.

${ }^{656}$ A maior parte dos fragmentos são explicações ou exposições de preceitos da lei das XII tábuas colhidos nos autores clássicos; mesmo as citações «literais» proviriam da tradição oral, com um teor próximo ao original, já que a sua ortografia não está de acordo com a vigente no séc. $V$ antes da nossa era (Cf. E. CouRTNEY, Archaic Latin Prose, London, Oxford University, 2000, p. 13). A modernização teria tido um intento, por um lado, de facilitar a prática legal (idem, ibidem) e, por outro, de permitir a sua memorização (Cic. de leg. 2, 59); assim, Th. Mommsen, Die unteritalischen Dialekte, Leipzig, G. Wigand, 1850, p. 32, n. 37, que sustenta a hipótese de que Sextus Aelius Cato, o mais antigo o comentador, tivesse modernizado o texto. Mas o seu conteúdo, nada impede, diz LENEL, SZ 26 (1905), p. 517, seja do séc. V. Se damos crédito a Cícero, há um fragmento da lei (diretamente aludido como uma inscrição contida na décima tábua em Cic. de leg. 2, 64) que faz referência ao antigo costume - tipicamente etrusco - de revestir de pompa e luxo as cerimônias fúnebres, que teria sido coibido com base na legislação de Sólon, que data do séc. VI a.C.: «iam cetera in XII minuendi sumptus lamentationisque funeris, translata de Solonis fere legibus» (de leg. 2, 59, linhas 1-3); e, como se não bastasse, refere uma interpretação de Sex. Aelius e L. Acilius, mencionando uma palavra do léxico decenviral ora obscura: «lessum», que esses comentadores suspeitaram ser algo como "vestimenti aliquod generis funebris», enquanto L. Aelius a traduziu, de modo aproximado, por «lugubris eiulatio». Essa passagem de Cícero serve, de qualquer modo, a dois propósitos: provar a antiguidade da lei decenviral e a falta de atualidade (o desuso) de certas palavras que compunham o seu léxico.

${ }^{657}$ Carente de evidências a afirmação de W. H. D. SURINGAR, Historia critica scholiastarum latinorum I, Lugduni, Luchtmann, 1834, p. 48: "Quidquid hac de re sit, Gajus ea saltem aetate vixit, qua

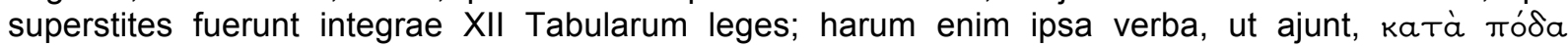
interpretatus est».

${ }^{658}$ Pal. I, pp. 242-246.

${ }^{659}$ Pomp. enchir., D. 1, 2, 2, 38: «Deinde Sextus Aelius et frater eius Publius Aelius et Publius Atilius maximam scientiam in profitendo habuerunt, ut duo Aelii etiam consules fuerint, Atilius autem primus a populo Sapiens appellatus est. Sextum Aelium etiam Ennius laudavit et exstat illius liber qui inscribitur 'tripertita', qui liber veluti cunabula iuris continet: tripertita autem dicitur, quoniam lege duodecim tabularum praeposita iungitur interpretatio, deinde subtexitur legis actio». Cícero recorre a Sex. Aelius para a definição de um vocábulo em top. 10, 8. Cf. também o truncado fragmento de Fest. 352, embora a referência, assim pensamos, possa ser a Aelius Stilo, várias vezes citado nesta obra. 
Julgamos provável, nesse sentido, que o famoso Tripertita de Sextus Aelius contivesse uma transcrição ou paráfrase da lei das XII tábuas, e servisse usualmente de fonte indireta da inscrição original, desprezada em virtude da sua antigüidade, ou inacessível, na sua originalidade, depois do saque de Roma pelos gauleses. Demonstra-o, aliás, a afirmação de Políbio de que os romanos da República tardia tinham sérias dificuldades em compreender o latim do séc. III a.C. ${ }^{660}$

Uma hipótese razoável seria a de que Gaio e outros intérpretes tivessem em mãos paráfrases, em latim corrente, das disposições das XII tábuas; ou ao menos que Cícero a tivesse reescrito com a finalidade de torná-la legível, sendo famoso o horror dos romanos da época clássica pelo demasiado arcaico - a exemplo da horrida vetustas do carmen Arvale ${ }^{661}$ cuja compreensão thes era muito difícil.

Uma forte demonstração desse ponto é a forma arcaica da palavra usus, que como veremos diverge da empregada por Cícero. Isso nos obriga a uma breve reconstrução «ortográfica» do preceito decenviral. ${ }^{662}$

Numa lei relativamente tardia (244-204 a.C.), se comparada com o «código decenviral», encontramos já o termo oetier, de clara procedência arcaica. Trata-se de um fragmento da Lex Silia de ponderibus publicis, ${ }^{663}$ conservada por Festo $^{664}$ - um autor conhecido pela sua preocupação em legar à posteridade as antigüidades romanas, mesmo no que diz respeito à ortografia.

O começo do fragmento diz: «Ex ponderibus publicis, quibus hac tempestate populus oetier solet, etc». Oetier (bem como oetor > oitor) corresponde a uti, no infinitivo passivo; uma forma mais recente, mas ainda antiga, pode ser

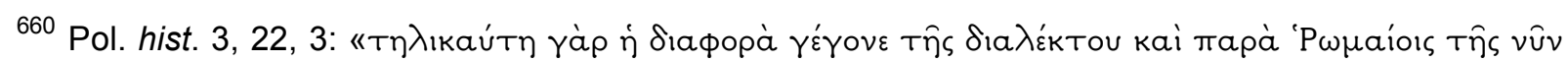

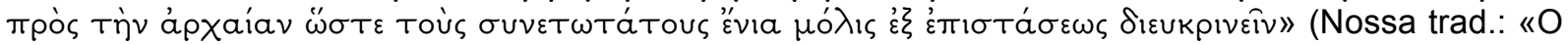
fato é que a antiga língua é tão diferente daquela que está em uso nos dias que correm, que mesmo os mais sábios entre os romanos têm grande dificuldade em lidar com algumas passagens»). Políbio se refere aos termos do primeiro tratado entre Roma e Cartago.

${ }_{661}^{6} \mathrm{CIL} \mathrm{I}^{2} 2$.

${ }^{662}$ Uma investigação deste tipo, embora em parte fundada em hipóteses, justifica-se pela inexistência de um estudo sobre o tema em sede romanística; os romanistas parecem ignorar que o latim de Cícero simplesmente não corresponde ao séc. V antes de Cristo, como demonstraremos adiante.

${ }^{663}$ FIRA I, 79. Cf. Gai. 4, 19 (lex Calpurnia); L. LANGE, Römische Alterthümer II, Berlin, Weidmann, 1862, p. 563; M. KASER, Das altrömische ius... cit., p. 57; R. ORESTANO, BIDR 44 (1936-1937), p. 274.

${ }^{664}$ Fest. 246. 
encontrada em Plaut. Cas. 2, 3, 220: «eos eo condimento uno utier», e em Ter. Phorm. 4, 2, 603: "commodius esse opinor duplici spe utier».

Mas e quanto ao substantivo usus, que nos interessa mais de perto? $\mathrm{O}$ seu correspondente arcaico é oıssos, ${ }^{665}$ que encontramos numa forma posterior em Cic. leg. 3, 10: «Ast quid erit quod extra magistratus coerari oesus sit, etc». ${ }^{666}$

A razão é que no latim arcaico - que seria o latim correspondente ao estágio lingüístico decenviral - a vogal longa $\bar{u}$, que vemos consolidada no latim clássico, e mesmo pré-clássico (early Latin), como vimos nas citações de Plauto e Terêncio, era representada pelo ditongo oi, oe. A seqüência seria então oi > oe > $\bar{u}^{667}$

Fundus é também vocábulo latino dos mais antigos - certamente utilizado no século $V$, pela sua importância social -, embora não haja, aparentemente, registro da sua forma arcaica; cogita-se FVNDOs, ${ }^{668}$ gen. FVNDOI. O seu sentido original é muito debatido. ${ }^{669}$

665 F. SOMmer, Handbuch der Lateinischen Laut- und Formenlehre - Eine Einführung in das Sprachwissenschaftliche Studium des Lateins, Heidelberg, C. Winter, 1948, pp. 241: «ūsus aus *oissos».

666 Assim, curari por coerari. Cf. W. M. LINDSAY, The Latin Language: An Historical Account of Latin Sounds, Stems and Flexions, Oxford, Clarendon, 1894, p. 248. A «Duenus-Inschrift», do séc. VI a.C., traz OISSI, embora sua leitura seja por demais controversa ( $\left.\mathrm{CIL} 1^{2} 4\right)$; cf. E. TICHY, Gr. oíosiv, lat. uti und die Mittelzeile der Duenos-Inschrift, in Glotta 78 (2004), pp. 179-202.

667 K. BRUGMANN, Kurze vergleichende Grammatik der indogermanischen Sprachen, Berlin, de Gruyter, 1969, p. 84: "oi wurde über oe zu ū; oe galt zur Zeit des Plautus», embora tenhamos encontrado uma exceção no próprio Plauto (v. acima). Cf. também H. H. JANSEN, Historische grammatica van het Latijn, Utrecht, Spectrum, 1992, p. 32. Em sentido contrário, A. R. DYCK, A Commentary on Cicero, De Legibus, Michigan, University of Michigan, 2004, pp. 471-472. Não é segura a correspondência entre uittiuf, do osco, e o latim arcaico oesus (cf. usio, Cat. de agr. 149, 2); foneticamente, entretanto, são muito semelhantes. A sustentar esse parentesco, A. WALDE, J. B. HofmanN, Lateinisches etymologisches Wörterbuch, $5^{\text {a }}$. ed., Heidelberg, C. Winter, 1982, p. 848.

${ }^{668}$ Como em PLAVTIVS > PLAVTIOS; cf., como testemunha epigráfica, uma inscrição sobre bronze de Preneste em CIL $1^{2}$ 561b: «NOVOIS PLAUTIOS MED ROMAI FECID».

669 G. BeSELER, in SZ 49 (1929), p. 450 dá fundus como originário de fendere, com o sentido de obligatus, embora não ofereça prova alguma dessa afirmação; essa tese é rejeitada por A. WALDE, J. B. HofMANN, Lateinisches etymologisches Wörterbuch cit., p. 565. Uma hipótese a explorar seria o sentido original de fundus como obligatus, refletindo sobre a expressão fundus fieri, ligada a auctor, de acordo com o sentido dado por Festo. Esclarecemos esse ponto no capítulo 4. J. MARQUARDT, Römische Staatsverwaltung I, 3. ${ }^{a}$ ed., Darmstadt, H. Gentner, 1957, p. 52, nt. 3, identifica fundus fieri com auctor fieri. V. também M. WEBER, Die römische Agrargeschichte in ihrer Bedeutung für das Staats- und Privatrecht (1891), reimpress., Tübingen, Mohr, 1986, pp. 171-172. E outro autor: «Fundus fieri was equivalent to being the auctor of, in the sense of being bound by» (E. G. HARDY, Roman laws and charters, Oxford, Clarendon, 1912, p. 161, n. 22). No mesmo sentido, W. A. BECKER, Handbuch der römischen Alterthümer - nach dem Quellen bearbeitet, vol. 1, Leipzig, Weidmann, 1851, p. 36, n. 
Não se pode questionar, ainda, o uso decenviral de biennium - annuus. Annuus procede do indo-europeu *atnos, ${ }^{670}$ conservado pelo osco aknos. Não há registro da sua forma arcaica, que seria provavelmente AMNVS/AMNOS, seguindo-se a grafia de traços mais arcaicos do vocábulo composto solL-EMNIS. Uma conjectura, já que não encontramos registro do composto biennium, seria o emprego de BIEMNIOM, de acordo com as terminações do latim corrente no tempo.

O imperativo ESTO costumava figurar em prescrições legais, de modo que não parece conveniente omiti-lo. A forma mais antiga é ESTOD, tal como na Lex Lucerina. ${ }^{671}$

Por fim, resta investigar a grafia de AVCTORITAS.

Há notícia de forma antiga de augur, auguratus: AVGER, AVGERATVS. ${ }^{672}$ Entretanto, o sinal $\langle G\rangle$ só entrou em uso no século III a.C. Já $0<C>$ foi objeto de uso generalizado desde meados do séc. VI a.C. ${ }^{673}$ De sorte que AVCTORITAS parece corresponder, em tese, à grafia antiga.

Uma conjectura para a grafia da norma decenviral, portanto, seria a seguinte: OISSOS AVCTORITAS FVNDOI BIEMNIOM ESTOD. ${ }^{674}$

De posse dessa tentativa de reconstrução, podemos concluir que a citação de Cícero seria apenas uma atualização ortográfica, por dois motivos: a)

68. Nas fontes romanas, cf. Gell. 16, 13, «fundus factus est»; Cic. pro Balb. 38: «fundos populos fieri non solere»; Cic. pro Balb. 8: «fundus fieri nolle»; Plaut. Trinn. 1123; Plaut. Truc. 214.

${ }^{670}$ F. SOMMER, Handbuch der Lateinischen... cit., pp. 232-233.

671 «In hoce loucarid stircus / ne[qu]is fundatid neve cadaver / proiecita(ti)d neve parentatid / sei quis arvorsu(m) hac faxit [ceiv]ium / quis volet pro ioudicatod $\mathrm{n}$ (ummum) / manum iniect(i)o estod seive / mag[i]steratus volet moltare / [li]cetod» (CIL IX 782).

672 Cf. o testemunho de Prisciano em H. KEIL, H. HAGEN, Grammatici latini, Hildesheim, G. Olms, 1961, p. 25.

673 J. StuART-Smith, Phonetics and Philology: Sound Change in Italic, London, Oxford University, 2004, p. 40. Embora o sinal $<\mathrm{K}>$ apareça na Lapis Niger, já citada; ela também serve de prova para a mudança do $<$ C > para o $<$ G $>$ em RECEI $>$ REGEI.

${ }^{674} \mathrm{Um}$ resultado semelhante ao nosso fora obtido no séc. XVII - portanto sem o aparato filológico de que hoje dispomos - pelo erudito Paulus Merula, cf. H. E. DIRKSEN, Uebersicht der bisherigen Versuche zur Kritik und Herstellung des Textes der Zwölf-Tafel-Fragmente, Leipzig, Hinrich, 1824, p. 417. Segundo Merula, a dicção original do fragmento seria: OISOS AVCTORITATESQUE FONDEI BIENNIS, (CETERARUM REROM ANVVS ESTOD). Note-se que a segunda parte do fragmento é certamente uma adição de Cícero, que contém, de qualquer modo, uma informação importante: com relação às outras coisas (móveis, na linguagem posterior), não se pode falar em auctoritas, mas apenas em usus. 
todos os vocábulos isolados pertencem, com alto grau de probabilidade, ao léxico latino da época decenviral; b) a sua sintaxe não é estranha à do latim arcaico. ${ }^{675}$

Mesmo conhecendo a história do instituto decenviral ou pré-decenviral, o fato é que Cícero expôs a norma do usus auctoritas... como a viam os juristas do seu tempo: a aquisição de um terreno ou edifício (o que já é uma interpretação mais abrangente em pro Caec. 19, 54 e top. 4, 23) após dois anos de uso, ou de coisas móveis em um ano. Isso é confirmado pela paráfrase grega de Teófilo.

A extensão do preceito para abranger as coisas móveis, além do uso do termo usucapio, na obra de Gaio, é mais um indício de que a própria concepção de usus auctoritas mudou; pois certamente havia um motivo para que, inicialmente, só fosse aplicável à categoria dos fundi.

Cremos que essa restrição aos fundi se deve ao contexto da norma decenviral, um tanto diferente do de Cícero e Gaio. A aquisição e limitação das terras em solo romano estava ligada a uma complexa tradição jurídica e religiosa.

O fato é que não é possível explicar porque usus auctoritas... passou a significar usucapião em sentido clássico sem recorrer a outros dados, que Cícero e Gaio não nos dão - a preocupação desses autores, ao menos quando mencionam o preceito decenviral, era com o direito da sua época, e não com o do séc. V a.C. ${ }^{676}$

Antes de passar a uma análise direta do preceito, vejamos se é pertinente, no contexto da interpretação clássica, a relação entre a regra do usus auctoritas... e a proibição de usucapir coisas furtadas prevista pela Lex Atinia.

\footnotetext{
${ }^{675}$ Cf. F. Sbordone, Per la sintassi delle XII tavole, in Synteleia Vicenzo Arangio Ruiz, Napoli, Jovene, 1964, pp. 334-339.

${ }^{676}$ Uma crítica que já se esboça aos autores que até hoje se debruçaram sobre o tema é a dificuldade de entender as diferenças entre o direito antigo e a sua interpretação pelos juristas clássicos e pósclássicos e autores da literatura latina, com exceção talvez de KASER e MAYER-MALY, como vimos. A norma do usus auctoritas... foi certamente reinterpretada por Cícero e Gaio, e os juristas modernos desde Budé e Alciat até o séc. XIX - subscreveram a sua exegese. A interpretação "garantista» do final do séc. XIX e do séc. XX nos parece um caso diferente: uma reinterpretação do preceito decenviral com base em outras fontes literárias (Plauto e Terêncio) e jurídicas (Paulo, Ulpiano, Venuleio, Scaevola e Papiniano), e em outras referências de Cícero ao termo auctoritas. Essa questão estudaremos adiante.
} 
Há duas menções importantes à Lex Atinia: ${ }^{677}$ uma feita por Aulo Gélio e outra por Paulo. ${ }^{678}$ Gélio faz uma citação literal da lei: quod subruptum erit, eius rei aeterna auctoritas esto. Já Paul. 54 ad ed., D. 41, 3, 4, 6, traduz esse preceito por res furtiva non usucapiatur. ${ }^{679}$ Curioso é que, segundo Gai. 2, 45, a lei das XII tábuas já proibia o usucapião de coisa furtada: furtivam lex XII tab. usucapi prohibet; entretanto, trata-se de uma opinião que o próprio Gaio reconhece como vulgar: vulgo dicitur.

Além disso, é evidente que, houvesse a proibição pela lei decenviral, não teria surgido a questão da irretroatividade da lex Atinia, suscitada por Gélio. ${ }^{680}$ Além disso, não se pode entender porque uma lei teria sido editada para dizer o mesmo que outra mais antiga, a não ser que fosse para introduzir algum pormenor ou mudança substancial. ${ }^{681}$ Não se sabe a data da lex Atinia - de qualquer modo posterior à legislação decenviral - embora Lívio mencione um tribuno da plebe de nome Atinius nomeado entre os anos 555 e $622 .{ }^{62}$

Ao que parece, ela teria reforçado o preceito decenviral, explicando, como podemos supor através da menção de Paulo, que a coisa furtada poderia ser usucapida se voltasse às mãos da vítima, em cujo domínio estivera: nisi in potestate eius, cui subrepta est, revertatur. Esta seria a inovação relativa da lei em comparação com a norma simples e direta presente nas XII tábuas.

O que nos interessa nessas duas fontes é o paralelo entre elas e a norma do usus auctoritas através dos elementos comuns auctoritas, passagem do tempo e usucapio. No preceito decenviral, segundo a interpretação de Gaio, o usus de dois anos leva à aquisição da coisa. No preceito da Lex Atinia, presente

\footnotetext{
677 Há também a menção de Justiniano, Inst. 2, 6, 2, que alguns julgam interpolada (o verbo no singular inhibet se refere ao sujeito lex duodecim tabularum, e não a lex Atinia, que parece inserido posteriormente; a passagem de Gaio não confirma a interpolação, pois se refere apenas a uma opinião do vulgo - v. Gai. 2, 45), e a de lulian. 44 ad Ed., D. 41, 3, 33 pr.

${ }^{678}$ Bruns I, n. 6, p. 47, nt. 10 menciona erroneamente Ulpiano.

679 «Quod autem dicit lex Atinia, ut res furtiva non usucapiatur, nisi in potestate eius, cui subrepta est, revertatur, sic acceptum est, ut in domini potestatem debeat reverti, non in eius utique, cui subreptum est, etc.».

${ }^{680}$ Gell. $17,7$.

681 D. DAUBE, Furtum proprium and furtum improprium, in Cambridge Law Journal 6 (1936-1938), p. 233, tem uma teoria diferente - a nosso ver sem apoio - sobre qual seria a inovação da Lex Atinia.

${ }^{682}$ Liv. 32, 29, 3; e 33, 22, 2. Se a lei foi de fato editada nesse período, ela seria do séc. III ou II a.C.
} 
originalmente nas XII tábuas, a auctoritas é eterna: é impossível que o usus, pelo tempo que seja, permita a aquisição. Em outras palavras, o efeito de uma auctoritas com duração infinita (para a vítima do furto) é a impossibilidade de que o autor do furto venha a obter propriedade ou posse legítima sobre a coisa furtada.

Dito isto, analisemos mais de perto - mas apenas formalmente, segundo a sintaxe - o preceito decenviral.

Temos algumas possibilidades de leitura sintática dessa regra. ${ }^{683}$

Uma delas, a mais comum, é a seguinte: usus auctoritas fundi I biennium esto, da qual teríamos algo como «o regime do usus auctoritas do imóvel se estende pelo espaço de dois anos». Ou ainda, de modo mais literal, "o usus e a auctoritas do imóvel duram [apenas] dois anos».

Ela pressupõe, corretamente, que usus auctoritas, na frase, é um termo composto de duas palavras; sintaticamente, um assíndeto. Tratar-se-ia, na nossa opinião, de um caso incomum, pois os assíndetos são sempre formados por palavras de sentido muito próximo ou complementar: emptio venditio, usus fructus, locatio conductio, ope consilio.

Além disso, nas outras ocorrências do termo auctoritas, ele está quase sempre acompanhado de uma palavra no genitivo, e nunca de outra na mesma declinação (dois nominativos ou acusativos, e. g.): auctoritas patrum, auctoritas tutoris, auctoritas census, auctoritas imperatoris, etc.

Teremos com isso de admitir que, pela primeira e única vez, auctoritas foi empregada ao lado de outra a modo de assíndeto, produzindo um novo sentido a

\footnotetext{
${ }^{683}$ A reconstrução dessa passagem das XII tábuas foi tentada por vários escritores antigos: a) Usus et authoritas fundi biennium esto: ceterarum rerum usus annus esto / Fundi usus auctoritas biennium esto, ceterarum rerum annus (Charondas); b) Ut usus auctoritas fundi biennis, ceterarum rerum annuus esset (Hotomanus); c) Usus auctoritas fundi biennium, coeterorum annus esto (Galvanus); d) Usus et auctoritas fundi bienniium esto: ceterarum rerum usus annuus esto (Contius/Pratejus); e) Usus auctoritas fundi biennium esto, ceterarum omnium rerum usus annus esto (Marcilius); f) Usus auctoritas fundi biennium, ceterarum rerum annuus usus esto (Rittershus); g) Usus auctoritas fundi biennium, ceterarum rerum annuus usus esto (Gothofredus); h) Usus auctoritas fundi biennium, ceterarum rerum annus (Haubold); i) Usus auctoritasque fundi biennis, ceterarum rerum annuus esto (Pighius); j) Oisos auctoritasque fondei biennis, ceterarum rerom annuus estod (Merula); k) Rerum mobilium annus, usus et auctoritas fundi biennium esto (Ramos). Cf. H. E. DIRKSEN, Uebersicht der bisherigen Versuche zur Kritik und Herstellung... cit., pp. 416-418.
} 
transcender as duas palavras isoladas. ${ }^{684}$ Isso parece improvável, mas o sentido global do adágio impõe-se - a história acima da lógica.

O grande erro dessa interpretação é supor que o usus do imóvel não continuasse após o fim do prazo. Isso implicaria uma distinção técnica totalmente anacrônica. Para os romanos - especialmente os antigos - o direito e a vida estavam estreitamente unidos. ${ }^{685}$

Uma leitura ligeiramente diferente seria: usus et auctoritas fundi I biennium esto, com o mesmo sentido de usus auctoritasque fundi / biennium esto. Esta última, a propósito, aparece em um manuscrito divergente, algo que não foi notado pela doutrina. ${ }^{686}$

Julgamos que em nada altera, essencialmente, a tradução da seqüência usus auctoritas por «auctoritas für den usus», ou melhor, auctoritas do usus, no genitivo. Ela aparece na passagem de Boécio: usus auctoritatem fundi..., e é repetida por Isidoro de Sevilha no séc. VI d.C. ${ }^{687}$

Embora haja um grande debate na romanística sobre essas duas leituras - assíndeto ou usus no genitivo -, parece-nos que elas podem sustentar a mesma interpretação. Dizer que o regime do usus auctoritas é de dois anos supondo-se que a auctoritas está ligada ao usus, e só permanece durante um ano ou biênio - ou que a norma prevê uma auctoritas baseada no usus com duração de dois anos, é cair numa única interpretação. ${ }^{688}$

\footnotetext{
${ }^{684}$ Pois esse é o uso do assíndeto, algo muito comum nas línguas indo-européias. J. WACKERNAGEL, Altindischen Grammatik II - Einleitung zur Wortlehre Nominalkomposition, Göttingen, Vanderhoek \& Ruprecht, 1905, p. 149, estudando o assíndeto nas línguas sânscrita, védica e outras, observa que se trata de dois ou mais substantivos que se tornam um composto cujo sentido é entendido como uma unidade conceitual, chamado pelos gramáticos dvandva, par. Nessas línguas, o assydeton bimembre, como é chamado em grego - um assíndeto formado por duas palavras - é muito mais comum do que no latim, mas o uso é idêntico. Alguns exemplos do autor: matárā-pitárā, mãe-e-pai, aspa vĩra ca, cavalos-e-homens, satāsati, verdadeiro e falso. São sempre vocábulos complementares ou opostos.

${ }^{685}$ Cf. R. ORESTANO, I fatti di normazione nell'esperienza romana arcaica, Torino, G. Giappichelli, 1967, pp. 69-70.

${ }^{686}$ E. g., na edição de C. L. Kayser, M. Tulli Ciceronis - Opera rethorica ex optimis libris manuscriptis, vol. 1, Lipsiae, B. Tauchnitz, 1860, p. 379: «quoniam usus auctoritasque fundi biennium est». Prevaleceu, entretanto, nas edições modernas, a variante que hoje conhecemos; a de H. M. Hubbell, 1949 , é a mais autorizada, trazendo «quoniam usus auctoritas fundi biennium est».

${ }^{687}$ Orig. 5, 25, 30.

${ }^{688}$ É também a opinião de A.-E. GIFFARD, Le sens du mot auctoritas cit., p. 355, que cita a mesma idéia de M. HUVELIN.
} 
Isso implicaria reconhecer ao possuidor de fato, ao detentor em linguagem moderna, antes do fim do prazo de um ou dois anos, algum poder, auctoritas; e é isso o que sustentam os autores da teoria dominante: embora não tenham propriedade, podem recorrer ao mancipio dans como auctor. ${ }^{689}$ Como isso não está expresso na norma decenviral, é necessário recorrer a outros grupos de fontes. ${ }^{690}$

Há ainda terceira possibilidade, de autoria de Hotomanus, ${ }^{691}$ não discutida pela doutrina. Trata-se da seguinte: usus fundi / auctoritas / biennium est, ou seja, em ordem direta, usus fundi biennium est auctoritas, o uso de dois anos conduz à (resulta na) auctoritas, como diz Boécio: fieri biennio. Uma variante pouco relevante, com repetição da palavra fundus no genitivo, seria: usus fundi biennium / est auctoritas fundi. Essa leitura se confirmaria pela seqüência da exposição de Cícero: et sunt ceterarum rerum omnium, quarum annuus est usus, que atribui a duração mínima de um ano ao uso das demais coisas, sem mencionar auctoritas.

Poder-se-ia dizer, ainda, que o verbo usado por Cícero está na terceira pessoa do singular, e não do plural, como seria de esperar se se tratasse de um sujeito também no plural: usus et auctoritas fundi biennium sunt. ${ }^{692}$ Mas se o sujeito é usus fundi, o emprego do verbo no singular está justificado.

As conseqüências dessa interpretação são as seguintes: a) o elemento temporal, o espaço de dois anos, se aplica ao usus, e não à auctoritas; b) o possuidor da coisa, no sentido fático, não teria auctoritas a não ser a partir do momento em que o prazo se completasse.

\footnotetext{
${ }^{689}$ Cf. especialmente M. KASER, Neue Studien zur altrömischen Eigentum cit., pp. 155-156. Fica fácil, assim, perceber o caminho trilhado pelos autores que sustentam a tese "garantista»: a auctoritas seria a possibilidade, o direito, a situação propícia reconhecida pelo direito romano para que o adquirente, caso necessário, recorra ao que Ihe transmitiu a coisa a fim de afirmar e provar a sua situação peculiar de quase-domínio. Está-se a um passo de afirmar que a auctoritas na verdade é um atributo do alienante, e não do adquirente, detentor atual da coisa; ou seja, do auctor, que segundo a etimologia é quem garante, torna segura - melhora, augeat - a situação do adquirente, quase sempre no contexto da mancipatio. Sem dar esse último passo, pode-se trilhar o caminho dos autores, em especial os do século $\mathrm{XX}$, que conceberam a auctoritas como título ou posição jurídica atribuída não ao alienante anterior na cadeia de domínio, mas ao próprio adquirente.

${ }^{690} \mathrm{~V}$. adiante.

${ }^{691}$ Cf. G. F. PuchtA, Adversus hostem aeterna auctoritas, in Kleine civilistische Schriften, Leipzig, Breitkopf und Härtel, 1851, p. 65.

${ }^{692} \mathrm{O}$ que é absolutamente óbvio, como em Cic. Acad. 1, 1, 26: «aqua et terra prima sunt».
} 
Não cremos que essa leitura seja correta para o contexto decenviral. No que diz respeito aos fundi, como veremos, tanto o usus (aquisição, posteriormente usucapio) como a auctoritas só passarão a existir juntamente - pois no período mais arcaico é a auctoritas a base anterior da legimidade, ou seja, o direito comunitário a uma parcela ideal a se concretizar com o usus de espaço de terra concreto - com o término do prazo de dois anos; no que diz respeito às demais coisas, de acordo com a observação de Cícero, adquire-se no prazo de um ano apenas usus, e não auctoritas.

Dito isto, a interpretação do adágio decenviral que propomos é a seguinte:

período decenviral:

usus fundi biennium est / auctoritas fundi biennium est

usus ceterarum rerum annuus est

período pré-clássico e clássico:

usucapio fundi biennia est

usucapio ceterarum rerum annua est

Com essa cisão, permite-se isolar os conceitos usus e auctoritas que, apesar de harmônicos, existem em uma relação de independência. Há que se notar que o verbo est, nas três leituras laterais, tem o sentido de "perfazer-se» (fieri, segundo o verbo usado por Boécio): só após o fim do prazo pode-se afirmar que há usus e/ou auctoritas em sentido pleno sobre a coisa concreta (embora houvesse, já, auctoritas, o direito à parcela ideal como participação na comunidade dos Quirites). Cremos que as palavras de Cícero - lex usum et auctoritatem fundi jubet esse biennium - explicam perfeitamente essa cisão.

Parece-nos lícito falar em um assíndeto, dada a antigüidade do preceito decenviral. Só assim faria sentido o uso do verbo sum no singular. Desta forma justificar-se-ia a sua tradução posterior em Cícero para usus et auctoritas. 
Voltaremos a essa questão mais tarde para definir, com maior detalhe, o funcionamento da norma decenviral.

Passemos ao segundo grupo de fontes, que compreende as seguintes passagens de Plauto: ${ }^{693}$

Plaut. Poen. 1, 1, 145-148

Agor. Si tibi lubido est aut voluptati, sino: suspende, vinci, verbera; auctor sum, sino. Mil. Si auctoritatem postea defugeris, ubi dissolutus tu sies, ego pendeam.

Plaut. Curc. 4, 2, 490-498

Lyco. Memento promisisse te, si quisquam hanc liberali causa manu assereret, mihi omne argentum redditum iri, minas triginta.

Capp. Meminero, de istoc quietus esto.

et nunc idem dico.

Curc. Et quidem meminisse ego haec volam te.

Capp. Memini, et mancupio tibi dabo.

Curc. Egon ab lenone quicquam mancupio accipiam, quibus sui nihil est nisi una lingua, qui abiurant si quid creditum est? alienos mancupatis, alienos manu emittitis alienisque imperatis, nec vobis auctor ullus est nec vosmet estis ulli.
Agor.: Se encontras prazer ou alegria nisto, eu o permito: suspende-me, prende-me, dá-me uma surra; eu lhe dou autorização, eu o permito.

Mil.: Mas se cancelares a autorização depois, quando escapares, eu é que serei suspenso.
Lyco: Lembra-te do que prometeste: que se alguém afirmar em juízo que ela é livre, todo o dinheiro deve ser devolvido a mim, trinta minas.

Cappadox: Lembrar-me-ei, fica tranqüilo a esse respeito; torno a dizê-lo.

Curculio: Eu mesmo também quero que te lembreis disso.

Capp.: Eu me lembro, e vou entregá-la em mancipio.

Curc.: Devo eu aceitar o mancipium de um alcoviteiro, gente que não tem nada a não ser a própria língua, e que, se algo lhe é confiado, nega até os votos que fez? Entregais o que é dos outros, libertais o que é dos outros, mandais em quem não é vosso, não servem de auctor quando transferem algo a vós, e nem servis de auctor a ninguém.

Mas se investigassem as suas fontes originais, de onde tiram o que escutam e repetem (e a não ser que as pudessem revelar, isso significaria enrascada e perda para a fofoca), se isso acontecesse, seria um benefício público.

Plaut. Trin. 1, 2, 217-222

Quod si exquiratur usque ab stirpe auctoritas, unde quidquid auditum dicant, nisi id appareat, famigeratori res sit cum damno et malo, hoc ita si fiat, publico fiat bono.

${ }^{693}$ Fizemos a opção de colocar os longos versos plautinos numa forma contínua (evitando a quebra dos parágrafos) - como é de costume -, a fim de facilitar a compreensão do texto. 
Essas referências são do séc. II a.C., portanto anteriores a Cícero. A questão mais importante que se nos apresenta é a da existência ou não de uma relação entre a norma devenviral do usus fundi biennium = auctoritas e a figura do auctor e da auctoritas (propriedade de quem é auctor), mencionada por Plauto.

A tese dominante simplesmente pressupõe a existência dessa relação. Para a doutrina da auctoritas-garantia, mais exatamente, as fontes plautinas são praticamente a base sobre a qual se assenta a interpretação do preceito decenviral.

Não há qualquer referência nas XII tábuas à suposta garantia prestada pelo mancipio dans ao adquirente; só depois de encontrar provas, especialmente em Plauto - porque se trata do autor mais antigo, mais próximo cronologicamente da lei decenviral - de que nos negócios (envolvendo mancipationes) o vendedor aparecia como auctor, ou seja, como alguém que, ao vender uma coisa, assumia a responsabilidade de defender o comprador em caso de uma reivindicação de terceiro sobre ela, é que puderam ligar essa figura à auctoritas da lei das XII tábuas, que trataria, apenas aparentemente, do usucapião.

Sem esse grupo de fontes pré-clássicas seria praticamente impossível sustentar a tese da auctoritas como garantia; não há nada no preceito decenviral que a autorize. ${ }^{694}$

Uma questão prévia é a da legitimidade do corpus plautino como fonte do direito romano. As teses de E. COSTA ${ }^{695}$ e de E. BEKKER ${ }^{696}$ em voga no final do séc. XIX e início do séc. XX favorecem fortemente essa legitimidade, mas foram contestadas por autores mais recentes, especialmente por U. E. PAOLI. ${ }^{697}$

Embora a dúvida permaneça, a posição de COSTA e BEKKER foi reabilitada recentemente por um trabalho importante. ${ }^{698}$ Mas continua dúbio, em

\footnotetext{
${ }^{694}$ Com exceção, talvez, do recurso à etimologia de auctor/auctoritas, com pouca evidência histórica se abstraído de um contexto mais claro.

695 II diritto privado romano nelle comedie di Plauto, Torino, 1890 (reimpr. Roma 1968); v. especialmente a p. 32. V. também o breve estudo de M. RADIN, Greek Law in Roman Comedy, in Classical Philology 5 (1910), pp. 365-367, bem como o de O. FREDERSHAUSEN, Weitere Studien über das Recht bei Plautus und Terenz, in Hermes 47 (1912), pp. 199-249.

${ }^{696}$ Die römischen Komiker als Rechtszeugen, in SZ 13 (1892), pp. 53-118.

${ }^{697}$ Comici latini e diritto attico, Milano, Giuffrè, 1962.

${ }^{698}$ P. LEITNER, Die plautinischen Komödien als Quellen des römischen Rechts, in E. CANTARELLA - L. GAGLIARDI (org.), Diritto e teatro in Grecia e a Roma, Milano, Giuffrè, 2007, pp. 69-93. V. também um estudo mais específico nesse mesmo sentido, A. ANTONSEN-REsch, Von Gnathon zu Saturio - Die
} 
parte, o argumento de que Plauto, embora tivesse utilizado cenários e nomes gregos e tivesse se inspirado em temas do drama grego, referia-se exclusivamente aos costumes e instituições romanos. ${ }^{699}$

Poenulus é geralmente aceita como uma obra inspirada no Karchedonios de Alexis, do qual temos poucos fragmentos. ${ }^{700}$ Em Poen. 3, 1, Agorastocles traz três possíveis testemunhas a fim de apoiar a farsa perpetrada pelo seu escravo; em um fragmento de Alexis, um personagem correlato realiza o mesmo ato; o que implica, segundo W. G. ARNOTT, que Plauto tomou do dramaturgo grego ao menos alguns elementos do enredo - e, podemos supor, do contexto social e jurídico - de Karchedonios. $^{701}$

Há uma boa prova, contudo, de que Plauto utiliza elementos do direito romano em sua peça. As passagens addicet praetor (verso 186), leno addicetur tibi (564), ne addicar Agorastocli (1341) e quin egomet tibi me addico (1361), como sugere E. LEFĖVE, ${ }^{702}$ parecem referir-se à entrega da pessoa do devedor ao credor por ato do pretor (addicere, adjudicar) - uma instituição tipicamente romana cujo equivalente grego foi abolido em Atenas, por decreto de Sólon, segundo o testemunho de Aristóteles. ${ }^{703}$

O fragmento dessa peça usado como fonte da teoria sobre a auctoritas tem como contexto a conversa inicial, no primeiro ato, entre o jovem cartaginense Agorastocles e seu escravo Milphio; o primeiro está apaixonado pela prostituta

Parasitenfigur und das Verhältnis der römischen Komödie zur griechischen, Berlin, W. de Gruyter, 2004.

${ }^{699} \mathrm{Em}$ favor dessa tese, E. FRAENKEL, Plautinisches im Plautus, 2. a ed., Hildesheim, Weidmann, 2000, p. 422.

${ }^{700}$ W. G. ARnotT, Alexis, Greek New Comedy and Plautus' Poenulus, in T. BAIER (org.), Studien zu Plautus' Poenulus, Tübingen, G. Narr, 2004, p. 61. Os fragmentos foram comentados em Alexis - The Fragments - A Commentary, Cambridge, Cambridge University, 1996. Sobre a comédia grega dessa época e para uma extensa bibliografia, v. H.-G. NESSELRATH, Die attische mittlere Komödie - ihre Stellung in der antiken Literaturkritik und Literaturgeschichte, Berlin, W. de Gruyter, 1990.

${ }^{701}$ W. G. ARNOTT, Alexis, Greek New Comedy... cit., p. 63; v. também W. G. ARNOTT, Alexis - The Fragments... cit., p.27.

702 Plautus' Poenulus zwischen Nea und Stegreifspiel, in T. BAIER (org.), Studien... cit., p. 16.

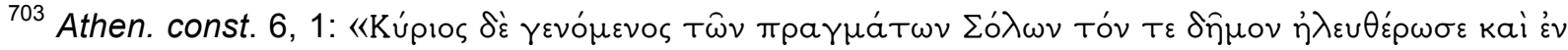

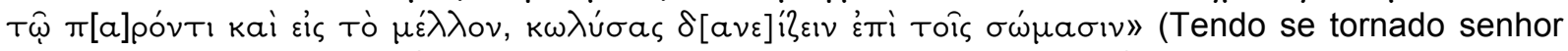
dos assuntos [da cidade], Sólon libertou o povo imediatamente e para o futuro, proibindo débitos com garantia sobre os corpos [dos devedores]). 
Adelphasium, escrava em poder do alcoviteiro (procurator) Lycos, e vai pedir a Milphio que o ajude com um plano fraudulento para obtê-la.

O discurso desses dois personagens não é propriamente jurídico, como se poderia pensar. Há uma alusão indireta, na melhor das hipóteses, ao vocabulário jurídico, na fala de Agorastocles - auctor sum, sino - e na de Milphio - si auctoritatem postea defugeris... ego pendeam.

Sugere MOMMSEN, assim como os demais autores da escola garantista, como vimos, que Plauto alude ao ato jurídico do vendedor que, ao entregar a coisa, responde pela eviç̧ão; e também, na fala do escravo, ao auctoritatem defugere, que pode ser traduzido juridicamente como «defraudar a garantia». ${ }^{704}$

Se alusão existe, não nos parece direta. Agorastocles diz que está arrependido por ter fustigado Milphio sem motivo algum. Milphio, provavelmente gracejando, propõe então fustigar o seu senhor da mesma forma, sem motivo; e ele acede, dizendo: «Se queres, e se isso te agrada, eu o permito (sino); amarre-me, prenda-me, fustigue-me, eu te garanto (auctor sum), eu o permito». Milphio então responde: "Se depois revogares a permissão (si auctoritatem postea defugeris), quando fores solto, eu é que serei amarrado [para ser punido]».

A expressão auctor sum é comum no latim vulgar, significando um convite à confiança do interlocutor, em Plauto sempre acompanhado de uma possibilidade de se provar o que se diz. Na outra ocorrência do termo - são apenas duas -, em Plaut. Merc. 2, 2, 312, Demiphio dá permissão (auctor sum) a Lysimachus para que o torture até a morte, a fim de provar o que diz. ${ }^{705}$ Auctoritatem defugere, em contraposição, significará defraudar a confiança depositada em quem deu sua palavra.

Não vemos como esse fragmento de Plauto possa sustentar a teoria da auctoritas-garantia, especialmente se partimos do adágio decenviral. Trata-se, como resulta evidente de uma leitura atenta do trecho teatral, de um uso dos vocábulos

\footnotetext{
${ }^{704}$ Ela aparece também em Cic. pro Sull. 33, com o sentido de «defraudar»: «itaque attende, Torquate, quam ego defugiam auctoritatem consulatus mei!»; e em Ter. eun. 3, 389 (citado erroneamente em F. J. CASINOS MORA, La noción romana de auctoritas... cit., p. 236): «cogo atque impero: numquam defugiam auctoritatem».

${ }_{705}$ «Si movero me seu secari sensero, Lysimache, auctor sum ut me amando enices».
} 
auctor e auctoritas demasiado vulgar, extra-negocial, bastante diferente do uso técnico pretendido por MOMMSEN em sua teoria.

O fragmento seguinte, tirado da peça Curculio, suscita um interesse maior. Trata-se de uma negociação entre o alcoviteiro Cappadox e Curcúlio, na presença de Lyco, um banqueiro, tendo como objeto uma suposta escrava a ser entregue por mancupio. Cappadox lembra-se do que prometeu: de que, se alguém afirmar em juízo que a escrava é livre, ele terá de devolver o preço da venda (trinta minas). O fato de Cappadox ser um alcoviteiro deixa Curcúlio inquieto: trata-se de um tipo pouco confiável, que, nas suas palavras, "nunca serve de auctor", que nunca cumpre a palavra dada e não tem bens com que responder.

Com essa fonte pretendeu-se provar a existência de um efeito direto da mancipatio: o de vincular o vendedor à responsabilidade pela eviç̧ão. Et mancupio tibi dabo significa que a escrava será entregue solenemente, e não por mera traditio; essa forma de entregar - isso estaria patente no diálogo - implicaria diretamente a responsabilidade por eviç̧ão: se a coisa não for do vendedor, o preço será devolvido.

O uso do termo auctor por Curculio provaria a vinculação entre a mancipatio e a auctoritas, nos termos da doutrina garantista. Entretanto, não há qualquer menção ao duplum; muito pelo contrário. Lyco fala na simples devolução do preço, mihi omne argentum redditum iri. Como vimos, a suposta actio auctoritatis, que também não é mencionada por Plauto, prevê, segundo a doutrina, a devolução do dobro do preço pago, provavelmente como punição, num caso análogo ao do furto.

Essa objeção já seria suficiente para afastar essa fonte como prova da doutrina garantista.

Mas há ainda outras objeções a essa exegese: a) o direito grego previa a proteção contra a evicção; b) o uso não-técnico do termo auctor por Curculio; c) a ausência de qualquer referência às doze tábuas, especilmente no que diz respeito ao prazo de dois anos; d) uma das partes é estrangeira; e) há uma clara referência a um negócio consensual prévio à mancipatio. 
Com efeito, era previsto no direito grego, especialmente no ateniense, um direito e uma ação com a finalidade de resguardar os riscos da eviç̧ão,

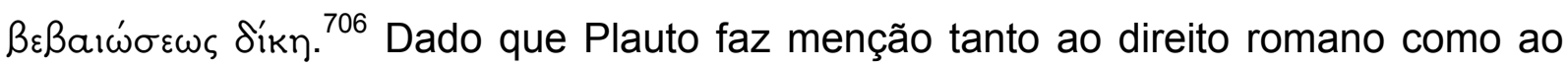
grego, não sabemos se a sua pretensa descrição do mecanismo da garantia é de se atribuir a um ou a outro direito. ${ }^{707}$

Certamente podemos traduzir o vocábulo auctor, usado por Plauto nesse trecho, por «garante». Mas não há qualquer indício de que se trate de um uso técnico de acordo com a tese garantista; embora empregue o termo legal mancupio,

\footnotetext{
${ }^{706}$ Há duas fontes indiretas que provam a existência dessa ação: os léxicos de Valerius Harpocration e Julius Pollux (Poludeukes), gramáticos alexandrinos do séc. II d.C. Vemos em Harpocr., verbete

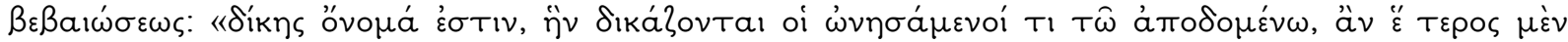

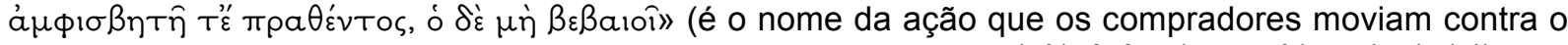

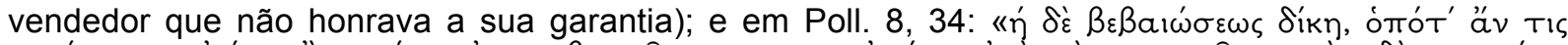

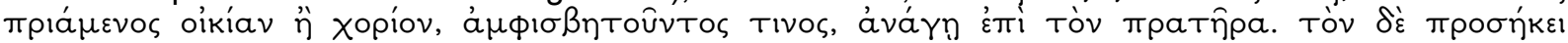

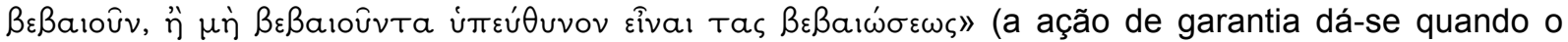
comprador de uma casa ou propriedade é contestado, recorrendo este, assim, ao vendedor. Ele dá a sua garantia ou, não a dando, fica responsável pela confirmação). Essas definições são razoavelmente claras; mas vejamos a explicação de um comentador: "Si cui empto agro aut domu, antiquitus de re empta moveretur controversia, opus erat ut emptor tòv á $\mu \phi 1 \sigma \beta \eta$ Toûvтos, id est controvertentem, ad venditorem duceret, et ab eo confirmationem rei venditae et controversae peteret,

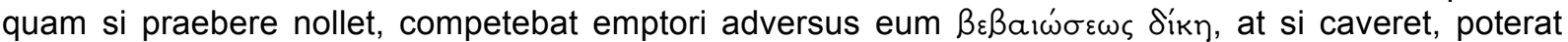

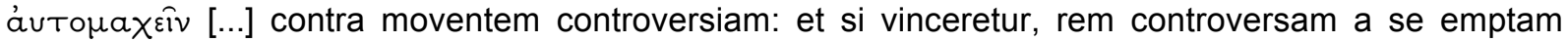
amittebat, victor enim rei dominus fiebat, sed victo licebat mulctam aut condemnationem petere ab eo qui caverat, id est venditore» (W. DINDORF, Harpocrationis lexicon in decem oratores atticos II Annotationes interpretum, London, Oxford, 1853, p. 154). Essa multa era o próprio preço do bem, e não o dobro, diversamente da teoria dominante sobre a actio auctoritatis e em consonância com a

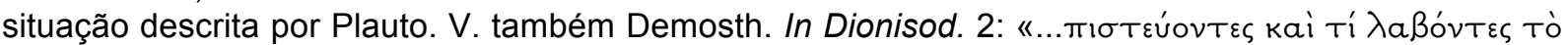

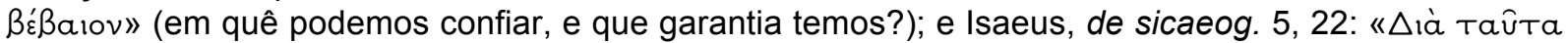

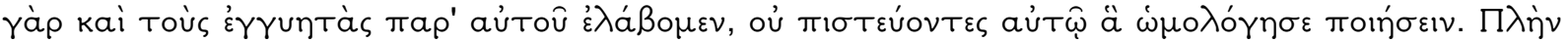

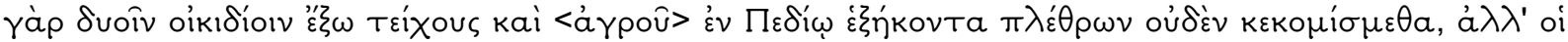

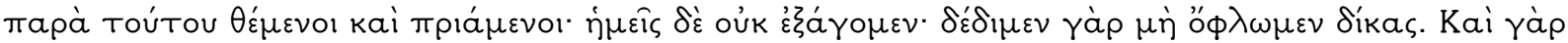

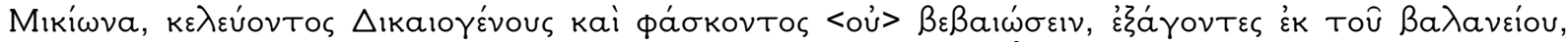

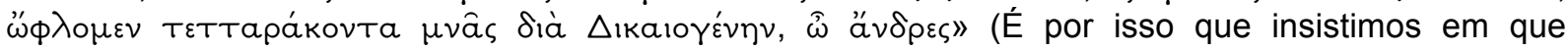
houvesse garantias, pois não confiávamos em que ele iria cumprir o contrato. Com exceção de dois pequenos prédios além dos muros e seis plethra de terra na Planície, não recuperamos nada: o restante está na posse daqueles aos quais vendemos ou em favor dos quais os penhoramos. Não tentamos despejá-los, pois tememos perder a causa; pois quando tentamos despejar Mícion da casa dos banhos, seguindo o conselho de Dicaógenes, que disse que não garantiria o seu título de propriedade, fomos multados em 40 minas, tudo isso por causa de Dicaógenes, ó homens).

${ }^{707}$ Em Trinummus, por exemplo, «the principal situations of the plot are everywere in accord with Greek law», e em várias outras situações dá-se um real confronto com o direito romano (W. M. GREEN, Greek and Roman Law in the Trinummus of Plautus, in Classical Philology $24^{2}$ (1929), p. 192; v. também M. RADIN, Greek Law in Roman Comedy cit., p. 366-367).
} 
que também tem um sentido vulgar, ${ }^{708}$ a fala de Curcúlio remete ao uso corrente de auctor como «pessoa digna de confiança». E não há, o que é mais sintomático, qualquer referência a uma actio auctoritatis. ${ }^{709}$

Supondo-se que Plauto tem em mente a «confirmação» de direito grego, mais flexível e informal ${ }^{710}$ do que a pretensa auctoritas-garantia romana, a passagem faz mais sentido. Auctor seria, de acordo com esse pressuposto, um

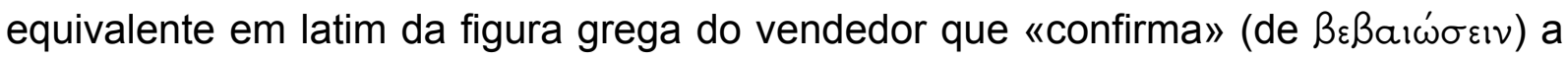
titularidade de um direito de propriedade.

\footnotetext{
${ }^{708}$ Inclusive amoroso, como na frase plautina «mulier, tibi me emancupo» (Bacch. 1, 1, 59), em que se emprega o termo técnico emancipare como metáfora (v. R. H. BROPHY, Emancipatus femina... cit., p. 1-11).

${ }^{709} \mathrm{~A}$ actio auctoritatis, segundo a doutrina, implica que o vendedor, ao realizar a mancipatio, assume automaticamente a posição de auctor. Isso está em forte contradição com a afirmação pouco rigorosa de Curcúlio, dirigida a Cappadox, de que este «não serve de auctor a ninguém»: claramente, o texto leva a pensar em uma posição de garantia voluntária ou facultativa, de modo algum automática. Paradoxalmente, o texto serve melhor à tese de O. KARLOWA, Römische Rechtsgeschichte II cit., p. 373 , segundo a qual a auctoritas era convencionada in mancipio por uma nuncupatio, tese que foi prontamente rechaçada pela doutrina (v. nossa exposição no item 2.2).

${ }^{710}$ Cf. a breve apreciação de P. MILLETT, Sale, credit and exchange in Athenian law and society, in Nomos: Essays in Athenian Law, Politics, and Society, Cambridge, Cambridge University, 1990, p. 175 e 179-180; v. também R. SEALEY, The Justice of the Greeks, Ann Arbor, University of Michigan, 1994, p. 62.
} 
4. Hipótese sobre a interpretação original da regra do usus auctoritas e seu contexto

O capítulo anterior forneceu elementos históricos e exegéticos para uma perspetiva do adágio decenviral bastante próxima - embora mais detalhada, em razão das contribuições da literatura histórica e jurídica mais recente - àquela de Cícero, Gaio e dos juristas do Humanismo (objeto de exposição no capítulo 2).

As fontes examinadas quase que apenas literalmente no último item, bem como os dados fornecidos pela historiografia e pela romanística (demais itens do capítulo anterior), agora nos servirão de base para uma hipótese de contornos mais claros.

Antes de fazê-lo, consideremos brevemente os passos do trabalho.

O fio condutor é a interpretação da regra decenviral do usus auctoritas.

Examinamos alguns pressupostos históricos que mostram (i) que é possível que a questão da evicção não estivesse distante da vida econômico-jurídica do período decenviral (item 1.1); mas (ii) que, mesmo assim, as teorias que enfatizam a garantia pela evicção no tratamento da regra do usus auctoritas carecem de fundamento para fazê-lo, especialmente por contrariarem a perspectiva de Gaio e Cícero, que nos transmitiram o fragmento como regra a respeito do usucapião (capítulo 2). Uma conclusão lateral é que o problema da evicção existia mas era contemplado por outras regras, talvez apenas incidentalmente, e por extensão interpretativa dos juristas, pela norma decenviral do usus auctoritas.

Em seguida, fornecemos as bases, no capítulo 3, para uma hipótese diversa sobre a regra do usus auctoritas, a ser apresentada neste quarto e último capítulo; a saber, a concretização do antigo direito à participação na comunidade (pré-)quiritária (fundus > auctoritas fundi) - que consistia numa medida ideal de terra - em um espaço definido, ocupado de modo duradouro através da posse e do cultivo (usus) nos limites da autoridade da gens. 
Partimos de alguns pressupostos teóricos sobre os modelos de usucapião moderno e romano (item 4.1) para em seguida oferecer um quadro histórico do "usucapião» pré-decenviral e decenviral (regra do usus auctoritas) compatível com mudanças substanciais no âmbito econômico-comunitário e jurídico da Roma arcaica.

A indicação dos contornos deste instituto durante os mencionados períodos históricos - com apoio nas conclusões dos capítulos 1, 2 e 3 - encerrará o escopo do presente trabalho.

\subsection{Considerações preliminares}

O modelo clássico do usucapião é conhecido. $A$, que é ou não proprietário de um bem, de algum modo permite que $B$ o possua (por exemplo, pela tradição), mas sem que haja uma transferência da propriedade. $B$ possui o bem de boa fé (ab initio), ad usucapionem, julgando-o seu, durante o tempo $t_{n}$. Se o decurso do tempo $t_{n}$ for igual ou superior ao tempo $\Delta$ t previsto em lei, ou seja, se $t_{n} \geqq \Delta \mathrm{t}$, o resultado jurídico é que $B$ usucapiu o bem. Sendo o usucapião um dos modos de aquisição da propriedade, tem-se a equivalência jurídica entre " $B$ usucapiu o bem" e " $B$ é proprietário do bem". ${ }^{711}$

A aplicação desse esquema aos imóveis introduz a questão espacial, de grande importância para nossa hipótese, como veremos. Não só o tempo $t_{n}$ é importante, mas também a área objeto da aquisição (o objeto do titulus). Enquanto a unidade corporal de um bem móvel é tratada tanto geométrica como juridicamente como um ponto sem necessária determinação espacial, ignorando-se também, para efeito de aquisição, as dimensões do objeto, a unidade de um bem imóvel diz respeito, grosso modo, a um plano bidimensional (especialmente se ignoramos os

\footnotetext{
${ }^{711}$ É essa, exatamente, a solução do Código Civil brasileiro. Limitamo-nos aos bens imóveis. O art. 1.238, situado no Livro III, Tit. III, Seção II, Cap. II - Da aquisição da propriedade imóvel, diz que «aquele que, por quinze anos, sem interrupção, nem oposição, possuir como seu um imóvel, adquireIhe a propriedade», etc. Basta ao novo proprietário uma sentença judicial que reconheça o decurso do tempo e demais requisitos, de eficácia declaratória, para que possa registrar o imóvel como seu junto ao cartório designado para aquela circunscrição (pelo critério da localização). Cf. F. C. PONTES DE MIRANDA, Tratado de direito privado XI - Direito das coisas: propriedade. Aquisição da propriedade imobiliária, 2.a ed., Rio de Janeiro, Borsoi, 1954, p. 118 e 146-148.
} 
limites aéreos e subterrâneos à propriedade e outros problemas análogos) ou mesmo a um objeto tridimensional situado num espaço que, em termos concretos, é geográfico, embora geometricamente reduzido, para efeito de mensuração. ${ }^{712} \mathrm{~A}$ redução ao modelo bidimensional é um expediente habitual: trata-se uma casa sobre um terreno como parte incorporada a este ${ }^{713}$ considerando-se como primordiais os limites traçados no solo ${ }^{714}$ - as coordenadas cartesianas no eixo $x$ e $y$ consideradas como delimitações do imóvel.

A unidade da propriedade imóvel, no que diz respeito à sua extensão espacial, ${ }^{715}$ entretanto, pode ser atingida pela idéia de título ou de «objeto do título».

No direito romano clássico, conforme o tratamento dado pela doutrina, o modelo do usucapião de imóveis é em linhas gerais semelhante - mas tem traços distintivos importantes. Recorde-se que o usucapião de bens móveis era, mesmo no período clássico, provavelmente bastante incomum e ${ }^{716}$ conforme pensamos, não há provas de que tenha existido no período arcaico, uma vez que a disposição decenviral correspondente liga a expressão completa usus auctoritas apenas aos fundi. $^{717}$

Definição clássica do usucapião romano é a de «aquisição da propriedade pela posse duradoura». É o que dizem as fontes, diretamente:

Modest. 5 pandect., D. 41, 3, 3:

Usucapio est adiectio [Cuj.: adeptio] dominii O usucapião é a aquisição do domínio per continuationem possessionis temporis através da posse contínua por tempo lege definiti. definido em lei.

\footnotetext{
${ }^{712}$ Esse plano pode ser regular - um quadrado, um retângulo, etc. -, a ser traçado com um número $n$, sendo $n$ menor que 2 e finito, de coordenadas espaciais; ou irregular, quando o número de coordenadas tende ao infinito. A ciência da agrimensura tende, no entanto, a geometrizar o espaço geográfico, reduzindo a complexidade das figuras; e mesmo a propriedade, em sentido jurídico, reconhece a necessidade de uma redução ao geométrico.

${ }^{713}$ Cf. o art. 79 do Código Civil: «São bens imóveis o solo e tudo quanto se the incorporar natural ou artificialmente».

${ }^{714}$ Como na regra de Marc. 3 inst., D. 43, 3, 39: «Si solum usucapi non poterit, nec superficies usucapietur».

715 «Extensão espacial» não constitui redundância porque se pode falar também em extensão temporal e conceitual.

716 "It is likely that usucapio of movable property was rather uncommon» (D. JOHNSON, Roman Law in Context, Cambridge, 1999, p. 57).

${ }^{717}$ Cf. item 3.5.
} 
Ulp. reg. 19, 8:

Usucapio est autem dominii adeptio per O usucapião é a aquisição do domínio continuationem possessionis anni vel através da posse contínua por um ou biennii. dois anos.

Boeth. ad Cic. top. 4, 23:

Usucapio est adeptio dominii per continuationem iustae possessionis vel biennii aut alicuius temporis.

O usucapião é a aquisição do domínio através da posse justa contínua por dois anos, ou então por outro tempo [determinado].

Temos, claramente, os seguintes elementos: (i) a aquisição do domínio (causa final); (ii) a posse contínua (causa instrumental «primária»); e (iii) o tempo prescrito em lei (causa instrumental «incidente» e variável). O que é essencial ao usucapião, mais do que o tempo concretamente previsto em lei, considerado apenas uma convenção legislativa, é a posse contínua. Afinal, ususcapio > usucapio é usu capio (ablativo) ou usus capio (genitivo), a aquisição da/pela posse. O elemento $t_{n} \geqq$ $\Delta$ t é acidental, quantitativo.

Delineamos brevemente o usucapião clássico - deixando de lado, por serem elementos secundários à exposição, os seus requisitos - a fim de compará-lo com a figura que, em nossa hipótese, configuraria uma espécie de pré-usucapião, a ser investigado nos itens seguintes.

Suponha-se a existência do seguinte instituto, que poderíamos chamar de «usucapião inverso»: em termos ingênuos, a aquisição da posse através da propriedade. A figura não é estranha à especulação jurídica, e muito menos à história dos direitos reais. Basta considerar o seguinte exemplo: $A$ é proprietário de um imóvel; tendo-o entregue a $B$ com cláusula de usufruto vitalício, passa a ser apenas nu-proprietário; com a morte de $B$, entretanto, e tendo $A$ falecido antes disso e deixado a seu sucessor $C$ a nua-propriedade do imóvel, $C$, que nunca teve a posse deste, adquire-a (no momento em que, tendo $B$ morrido, entra na posse direta do bem). Temos, na perspectiva de $C$, uma aquisição da posse fundada numa prévia atribuição de propriedade. Isso mostra que, teoricamente, a aquisição da posse 
fundada numa propriedade anteriormente existente ${ }^{718}$ não é um absurdo jurídico e possui incidência prática.

O direito costumeiro arcaico (pré-decenviral), como vimos, indica a existência de uma espécie de direito de participação na comunidade de cidadãos (fundus), mais tarde Quirites. Na prática, o titular de um tal direito, que consistia numa medida ideal de terra, estaria em situação ainda mais incerta que a de $C$, no exemplo acima: teria algo vagamente semelhante à propriedade em sentido clássico, mas o objeto de seu título seria indeterminado, sorte de nua-propriedade sem objeto. $^{719}$

Sustentaremos, nos itens seguintes, a existência de um «usucapião inverso» na história da regra do usus auctoritas, que explicaria as confusões que surgiram na discussão do tema. Veja-se: sem uma aquisição da posse legitimada pela auctoritas (usus auctoritas) é simplesmente impossível descrever o processo pelo qual os cidadãos de Roma e seus ancestrais ocuparam, gradualmente, o ager divisus et adsignatus, ligado intrinsecamente ao surgimento e desenvolvimento da propriedade quiritária e à afirmação «AIO HUNC FUNDUM MEUM ESSE EX IURE QUIRITIUM». ${ }^{720}$

É fundamental, para compreensão de nossa hipótese, tomar em consideração esse modelo explicativo mais abstrato. É dizer, novamente: o modo pelo qual ocorreu a gradual ocupação e transmissão da ocupação do ager divisus et adsignatus aos romanos tem como condição de possibilidade a regra do usus auctoritas em sua fórmula original.

\footnotetext{
${ }^{718}$ Ver nota abaixo.

${ }^{719} \mathrm{Em}$ outros termos, a fim de evitar um possível contra-senso jurídico - uma aquisição da posse através do exercício do direito de propriedade -, uma concepção demasiado estranha à sensibilidade moderna, poderíamos falar numa aquisição da propriedade plena (nua-propriedade integrada à posse) a partir de uma mera atribuição de quota ideal (Anrecht, em termos weberianos), compatível com um direito costumeiro comunitário. O que se preserva, aqui, do modelo clássico do usucapião, é o elemento da posse duradoura, presente também nessa hipótese arcaica.

720 "L'assegnazione era preceduta dalla limitatio, alla quale si procedeva mediante cerimonie augurali: segnate due strade maestre, l'una da nord a sud e l'altra seguendo il corso del sole (cardo maximus e decumanus $m$.), si tracciavano parallelamente all'una ed all'altra quelle che dovevano essere le linee di confine fra gli appezzamenti; l'assegnazione di questi si faceva normalmente a sorte. L'ager divisus et adsignatus era fra i terreni il solo suscettibile di proprietà privata, il solo che il proprietario potesse rivendicare dichiarando: aio hunc fundum meum esse ex iure Quiritium» (V. ARANGIO-RUIZ, Istituzioni di diritto romano, 14.a ed., Napoli, Jovene, 1960, p. 184).
} 


\section{2 $1 .^{\mathrm{a}}$ Fase - O sistema pré-cívico comunitário do Hufenverfassung ${ }^{721}$}

Nesse tempo, antes da formação da civitas, cada homem livre tem uma quota de participação na comunidade agrária - fundus, Genossenrecht -, conforme se extrai de investigações várias com opiniões convergentes, como as de $A$. Meitzen, ${ }^{722}$ M. Weber, ${ }^{723}$ Lambert, ${ }^{724}$ De Franciscl, ${ }^{725}$ Kübler, ${ }^{726}$ Pöhlmann, ${ }^{727}$ O. Behrends, R. Taubeschlag, ${ }^{728}$ Capogrossi Colognesi, ${ }^{729}$ Carandini, ${ }^{730}$ P. VINOGRADOFF ${ }^{731}$ e COLI. $^{732}$

721 Transcrições mais longas dos autores, a partir desse item, são justificadas pela necessidade de facilitar, ao leitor, a comprovação de pontos essenciais, em se tratando de passagens complexas e de difícil acesso na bibliografia. Basta lembrar que o tema exige o manejo de muitas fontes secundárias todas citadas no capítulo anterior - e de uma interpretação conjunta delas; os trechos dos autores citados neste item constituem um atalho.

${ }^{722}$ «...dass die ursprünglich mit je 2 iugera heredium im Pagus ansässigen patres familias der Gentes noch gleiche hufenartige Anrechte an dem übrigen weit überwiegenden Gemeinlande hatten, denn ihre Fundi wurden rechtlich durch das heredium und das gleiche Nutzungsrecht am Gemeinland gebildet» (Wanderungen, Anbau und Agrarrecht der Völker Europas nördlich der Alpen - Erste Abteilung: Siedelung und Agrarwesen der Westgermanen, Ostgermanen, der Kelten, Römer, Finnen und Slawen I, Berlin, Wilhelm Hertz, 1895, p. 307).

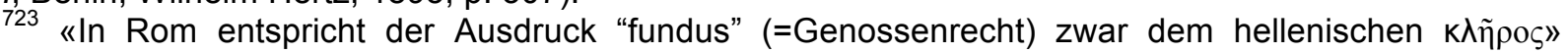
(Wirtschaft und Gesellschaft, 5.a ed., Tübingen, Mohr Siebeck, 1980, p. 153); «Der technische Ausdrück für Genossenrecht ist "fundus"» (Die römische Agrargeschichte..., p. 171).

${ }^{724}$ Les origines de Rome à la lumière du droit comparè, in Studi De Francisci I, Milano, Giuffrè, 1956, p. 348.

${ }^{725}$ Primordia civitatis cit., pp. 173-174.

${ }^{726}$ RE 7, p. 1182: «demnach bildete die G[ens] eine Markgenossenschaft; im vicus oder pagus wohnten die Geschlecht beisammen». Para uma comparação com o sistema da Markgenossenschaft medieval, mais bem documentado, cf. G. GROSCH, Markgenossenschaft und Grossgrundherrschaft im früheren Mittelalter - Eine staats- und rechtsgeschichtliche Untersuchung (reimpress. da ed. de 1911), Lübeck, Matthies, 1965.

${ }_{727}$ Geschichte der antiken Kommunismus und Sozialismus I cit., p. 14.

728 Das römische Privatrecht zur Zeit Diokletians, in Opera minora I, Warsaw, Panstwowe Wydawnictwo Naukowe, 1959, pp. 123: «Das charakteristische Merkmal dieser Verfassung bildet das Recht der Gemeinschaft, in die Besitzrechte der Genossen einzugreifen. Dieses Eingreifen kann von doppelter Art sein: entweder steht der Gemeinschaft das Recht zu, die Größe des Grundbesitzes ihrer Mitglieder zu bestimmen, das Maß des Besitzes auch gegen den Willen der Interessenten zu ändern (Umteilung), oder das Recht, die Grundstücke den jeweiligen Besitzern zu nehmen und unter dieselben nach Maßgabe ihres bisherigen Anrechtes wieder zu verteilen (Neuverlosungen)». A comparação é com o direito grego posterior, inclusive bizantino.

${ }^{729}$ Le communità rurali nell'Italia romana, in Les communautés rurales 2, 2, Paris, Dessain et Tolra, 1983, pp. 411-430.

${ }^{730}$ La nascita di Roma cit., pp. 436-439; e p. 190: «Le prime pietre terminali stanno ad indicare l'emergere del primo concetto di inviolabilità dei confini e di punizione estrema, di sanctitas, e quindi 
Esse modelo de soberania comunal é semelhante ao mencionado por Platão, que descreve um antigo ideal agrário:

\section{Leg. 739e-740a}

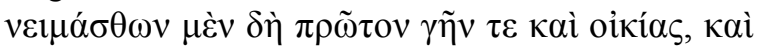

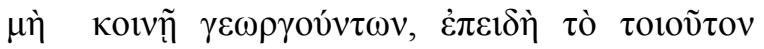

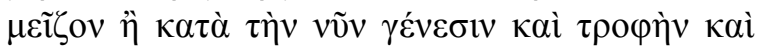

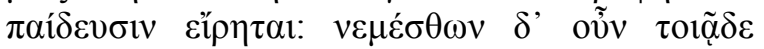

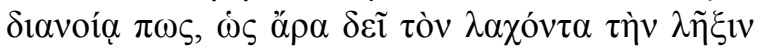

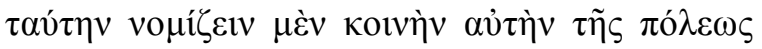
бu$\mu \pi \alpha ́ \sigma \eta \varsigma . .$.
Primeiramente, que parcelem o solo e as casas; mas que não cultivem em comum, pois isso seria impossível a pessoas com o nascimento, a educação e o treino que supomos. $E$ que $O$ parcelamento seja feito de acordo com essa intenção: que o homem que recebe sua porção encare-a como propriedade comum do estado como um todo.

Um sistema semelhante a esse - embora muito melhor documentado e descrito - era um dos pilares do direito fundiário galês. Segundo as antigas leis do país, todo cidadão nativo livre, membro da comunidade, tinha direito a um modus equivalente a cinco erws (uma medida-unidade, equivalente a uma «jeira legal») ${ }^{733}$ de terra. Para efetivar o título, realizava um pedido junto à autoridade (o senhor da terra) e, comprovando o direito como cidadão livre e membro da comunidade, era investido na posse de uma parcela física correspondente à medida ideal num terreno

anche delle primissime forme di diritto e sovranità. Questo insieme di circostanze implica condizioni piú progredite e programmate di vita agricola, maggiore consapevolezza delle distinzioni spaziali, almeno nelle piú raffinate colture dell'agro, quali l'arboricultura o la coltura promiscua, particolarmente adatte ai terreni collinari dei monti Albani, ed infine uma organizzazione comunitaria piú sviluppata, confermata dalla stessa presenza nel mito (quindi nel 'quadro concettuale' di quella società) dei re divini del Lazio e dalla lega di populi, che rimandano ad un 'quadro reale' sul genere del Chiefdom, che meglio potremmo definire di uma 'signoria preurbana', retta da patres collegati ad um rango privilegiato, riservato ai parenti piú vicini degli antenati comuni divinizzati».

${ }^{731}$ Outlines of Historical Jurisprudence I (reimpress. da ed. de 1920), New Jersey, Lawbook Exchange, 1999 , p. 327.

732 II diritto pubblico dgli Umbri cit., p. 87 : «All'origine della maggior parte degli Stati antichi divenuti Stati-città esiste un insediamento collettivo risalente a epoca più o meno remota. Tali insediamenti collettivi non avvenivano alla rinfusa, bensì secondo schemi geometrici ed aritmetici, che comportavano la distribuzione del territorio in un numero rituale di lotti, ciascuno dei quali era destinato ad um nucleo familiare. II sistema di fondazione delle colonie in epoca storica reproduceva quei primitivi insediamenti, le cui norme erano tremandate daí libri rituales».

${ }^{733} \mathrm{Um}$ erw no sul de Gales era equivalente a aproximadamente 6.561 pés quadrados. 
reservado para esse fim. A posse era garantida com a colocação de marcos de limitação. ${ }^{734}$

Como afirmava MeITZEN, entre os habitantes da mais antiga Roma ainda em formação (entenda-se: na área rural), cada pater familias pertencente a uma gens, além de ter para si o heredium (ou o que mais tarde receberá esse nome), cultivava parcelas de terra no proto-ager romanus (ager gentilicius). O fundus compreendia o heredium e o "direito» de usus sobre mais parcelas ao redor. $\mathrm{Na}$ prática, seu direito de participação concretizado no usus sobre porções do solo (fora do heredium) tinha de ser mais tarde reconhecido através de um processo conduzido sob os auspícios da autoridade da comunidade gentílica. Ele culminava na garantia (auctoritas, em nossa interpretação) sobre o usus das parcelas, caso estivesse dentro dos limites do modus agri a que tinha direito. Isso implicava o reconhecimento destas parcelas ocupadas («okkupatorisch bessessene ager romanus») de forma duradoura. $^{735}$

Nesse contexto não se pode falar, entretanto, em propriedade privada em sentido quiritário, mas apenas num usus assegurado por tempo indefinido.

Num tempo em que apenas um modus ou medida ideal de terra arável era atribuído às famílias, para adquir o direito ao uso continuado e temporariamente exclusivo de uma parcela concreta dentro do ager gentílico reservado ao uso «comum» (mas particularizado), era necessário possuí-la por tempo suficiente, demarcando-a de acordo com os costumes e a convenientia possessorum (ausente ainda a arte augural, e muito menos uma técnica formal-matemática de agrimensura). O mais importante, como dito, é que essa posse estivesse fundada no Genossenrecht, no direito de participação na comunidade agrária. ${ }^{736}$ Esses eram, segundo pensamos, os requisitos do processo de aquisição legítima do usus fundiário referido por MEITZEN.

\footnotetext{
${ }^{734}$ H. LeWIS, The Ancient Laws of Wales..., p. 120-123. Cf. também J. E. LLOYD, A History of Wales from the Earliest Times to the Edwardian Conquest I (reimpress. da ed. de 1911), Charleston, BiblioLife, 2009, p. 297.

${ }^{735}$ Siedlung und Agrarwesen..., p. 309.

${ }^{736}$ Enquano os dois iugera estavam garantidos pelas atribuições gentílicas, é bastante provável que obtivessem pelo usus em média cinco iugera a mais, a fim de garantir sua subsistência. É a hipótese de A. Meitzen, Siedlung und Agrarwesen..., p. 309.
} 
Em outras palavras, a posse continuada de um terreno mais ou menos demarcado chama-se usus no sentido de posse legítima ligada a um locus, em oposição ao direito abstrato (Anrecht) de participação.

Abandonado um local por tempo suficiente, o seu usus pode ser exercido por outro colono (daí o possível sentido original do imemorial adágio "adversus hostem aeterna auctoritas esto») munido de uma quota de participação dentro do sistema do Hufenverfassung, na terminologia de MEITZEN e WEBER.

Nesse contexto, o direito ou Anrecht correspondente a um modus, bem como o próprio exercício desse direito pelo usus, depende totalmente, como já dito, da soberania gentílica sobre o solo (Bodenhoheit, na exposição de O. BEHRENDS), ou seja, da auctoritas da gens ou do soberano que a representa. ${ }^{737} \mathrm{O}$ indivíduo, mesmo o pater familias, não possui auctoritas, embora goze de uma investidura agrária com fundamento nela.

Essa auctoritas - participação na soberania da gens - não atinge o heredium, a casa e a pequena extensão de solo (praedium parvulum) destinada à posse continuada e exclusiva de uma família (a mansão ancestral). ${ }^{738} \mathrm{O}$ heredium, conforme regra formalizada posteriormente, só volta à gens quando não há sucessores ou adgnati, como na regra posterior das XII tábuas ( $\mathrm{V}, 5)$ : «si adgnatus nec escit, gentiles familiam habento»).

Usus concerne, portanto, um locus, enquanto a auctoritas gentílica se refere primariamente a um modus; o usus auctoritas representaria, nesse modelo jurídico ainda em formação, a garantia ou proteção de um locus nos limites da medida ideal ou modus (Anteilsrecht); mas é apenas hipotético o uso concreto, pelos falantes do latim arcaico pré-decenviral, do assíndeto, uma vez que nos referimos a

737 Em termos arqueológicos, o que se demonstra é, num primeiro momento, uma certa homogeneidade entre as linhagens, em virtude da igualdade observada nos cemitérios (formados muitas vezes por funeral huts indistintos); e no séc. VIII a.C uma proliferação de distinções funerárias, que indica concentração da autoridade nas mãos de grupos familiares mais importantes (M. TORELLI, Archaic Rome between Latium and Etruria, in F. W. WALBANK, A. E. Astin (ed.), The Cambridge Ancient History VII - Part 2: The Rise of Rome to 220 B.C., Cambridge, Cambridge University, 2008, pp. 34-35).

${ }^{738}$ Primordia civitatis cit., p. 173; C. W. WESTRUP, Introduction to Early Roman Law II.., p. 60-61: «In contrast to the ager romanus, which - we may assume - was still the joint property of the gens and consequently not 'heritable' within the individual family, the heredium quod heredem sequeretur was the praedium parvulum set off as heritable family property». 
um período anterior ao das XII tábuas, pré-decenviral, e primariamente préfundacional. Trata-se de uma regra costumeira em formação, substrato da norma que, mais tarde, integrará o direito decenviral.

Esse modelo de aproveitamento do solo, já com incipientes elementos jurídicos formalizados pelo costume, encontra apoio não só na literatura históricojurídica, nas teorias de MEITZEN, WEBER e outros, bem como no imaginário romano posterior, mas principalmente na arqueologia. ${ }^{739}$

\subsection{2. ${ }^{\text {a }}$ Fase - Na era cívica: sistema de limitação augural}

No século VIII, segundo a tradição no ano de 753 a.C, temos um evento que, do ponto de vista estritamente histórico, corresponde comprovadamente à formação da civitas, com ou sem um ato de fundação rigidamente demarcado. As teses teoricamente opostas - a da fundação oficial de Roma e a da lenta constituição de uma cidade unificada a partir de antigos assentamentos (formações urbanas) convergem num ponto indiscutível, de seminal importância para a investigação da origem do ius civile e da propriedade fundiária: o término de uma fase proto-romana gentílica e o início gradual da civitas, por influência do domínio político e urbanístico

${ }^{739}$ Cf. em geral, o recente artigo de R. T. ScOTT, The Contribution of Archaeology to Early Roman History, in K. A. RAAFLAUB, Social Struggles in Archaic Rome: New Perspectives on the Conflict of the Orders, Oxford, Blackwell, 2005, pp. 98-105. Os dados arqueológicos mais seguros de que dispomos até o ano de 2008 permitem o seguinte quadro, em linhas gerais. Entre os séculos X e IX a.C no Lácio, as colinas de Alba ocupam uma posição de destaque, com comunidades ligadas por laços familiares em vilas e pequenos assentamentos (colônias) nos quais se pratica uma agricultura de subsistência (cereais de baixa qualidade e outros vegetais pouco valiosos) de modo estável, tendo se encerrado o período de instabilidade característico da Idade do Bronze. Essa estabilidade posterior se deve ao meio de propriedade por excelência do mundo antigo: a terra, possuída de modo coletivo. Paralelamente ao empobrecimento da região das colinas de Alba, observado a partir da diminuição do tamanho e da riqueza dos cemitérios, temos o florecimento de assentamentos nas planícies, como Roma, Lavinium, Ficana e Gabii. Em seguida, a partir do séc. IX, observa-se um movimento evidente de expansão colonial tanto na Etrúria quanto no Lácio - com assentamentos no padrão Villanova, cultura subseqüente à da Idade do Bronze, que introduziu o uso do ferro (sobre essa transição, v. S. SHERRATT, A. SHERRATT, The Growth of the Mediterranean Economy in the Early First Millenium B.C., in Word Archeology $24^{3}$ (1993), pp. 361-378) - simultâneo a um considerável crescimento da agricultura lucrativa, especialmente no Quirinal, na região da (proto-)Roma (v. principais resultados e literatura em T. J. CORNELL, Rome and Latium Vetus, 1974-1979, in Archaeological Reports 26 (19791980), pp. 71-89; idem, Rome and Latium Vetus, 1980-1985, in Archaeological Reports 32 (19851986), pp. 123-133). 
etrusco (embora com uma heróica conservação do elemento propriamente latino), parelelo à sobrevivência das gentes e seu sistema de uso do solo. ${ }^{740}$

Como vimos, a formação da civitas pressupõe a passagem da soberania que a gens mantinha sobre certas partes do solo (ager gentilicius/gentilicus) ${ }^{741}$ para o incipiente populus Romanus Quirites, de natureza moderadamente revolucionária. ${ }^{742}$ Ela coincide com a origem ou fortalecimento do sistema de limitação augural, exaustivamente discutido no capítulo anterior. Esse sistema tem como elemento primordial a centúria, tipicamente romana: um espaço no solo dividido em parcelas iguais segundo ritos religiosos, de início apenas grosseiramente demarcadas, dado o estágio ainda incipiente da agrimensura, dominada por augures e talvez sem qualquer auxílio técnico formal.

Outro dado importante é que havia, sem sombra de dúvidas, um direito costumeiro já desde o início, ${ }^{743}$ que por sua vez se apresenta como uma continuação

\footnotetext{
${ }^{740}$ Temos como arqueologicamente bem fundamentados dois modos de aproveitamento do solo: (i) a «propriedade» familiar, normalmente ligada ao heredium, segundo pensamos (depois estendida a maiores parecelas de acordo com o mesmo padrão), que se desdobrou na futura propriedade quiritária, de caráter inovador e revolucionário; e (ii) a de natureza tribal e estritamente coletiva, ligada à gens (cf. M. TORELLI, Archaic Rome between Latium and Etruria... cit., p. 38). Dado que inicialmente só tínhamos a gens, a influência do modo gentílico de aproveitamento do solo sobre o posterior modo individualista, quiritário, é uma conseqüência lógica.

${ }^{741}$ Não se pode minimizar o testemunho de Festo a respeito da origem do termo pater para designar os senadores: "patres Senatores ideo appellati sunt, quia agrorum partes adtribuerant tenuioribus ac si liberis propriis» (Fest. 289). Com base nisso, diz-se que cada gens tinha, no período pré-romano, como explicamos acima, a sua parcela de terra originariamente tomada por conquista; esse ager gentilicus (o nome é bastante discutido por C. R. NOYES, The Institution of Property - A Study of the Development, Substance and Arrangement of the System of Property in Modern Anglo-American Law, Clark, The Lawbook Exchange, 2007, p. 94, n. 247) era supostamente distribuído pelo pater gentis aos seus membros individuais, enquanto o restante continuaria em propriedade coletiva (S. T. ROSELAAR, Public Land in the Roman Republic - A Social and Economic History of Ager Publicus in Italy, 396-89 $B C$, New York, Oxford University, 2010, p. 20-21). Discutimos toda a literatura no item 3.1; cf. sobretudo L. CAPOGROSSI COLOGNESI, 'Ager publicus' e 'ager gentilicus' nella riflessione storiografica moderna cit., p. 71-106.

${ }^{742} \mathrm{O}$ que se observa desde meados do séc. VIII é o surgimento de uma classe aristocrática e do clientelismo; o crescimento de alguns assentamentos e núcleos urbanos e o desaparecimento de outros; conflitos entre grupos; conquista de território por parte dos agrupamentos maiores (os Quirites e o crescente fundamento bélico do direito de propriedade fazem parte dessa mudança); acúmulo de riquezas baseado em novas técnicas agrículas; o surgimento de estruturas arquitetônicas mais duradouras; tudo isso tendo como evidência maior o surgimento da cidade, a civitas no Lácio e na Etrúria (idem, p. 39-48, com dados bibliográficos e arqueológicos).

${ }^{743}$ «Daß in den Anfängen Roms die Rechtsbildung hauptsächtlich eine gewohnheitsrechtliche war, sagt nicht bloß die römische Tradition, die dabei die Kraft der gerichtlichen Sprüche besonders betont, sondern es wird auch bestätigt durch die allgemeine geschichtliche Erfahrung» (T. Kipp, Geschichte der Quellen des römischen Rechts, 4. ed., Leipzig, A. Deichert, 1919, p. 17.
} 
do direito das aglomerações tribais e gentílicas pré-romanas; como nos lembra

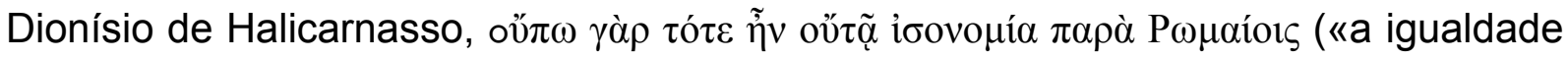

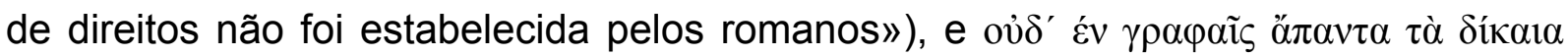
$\tau \varepsilon \tau \alpha \gamma \mu \varepsilon ́ v \alpha$ («e o direito não era escrito [conhecido]»). ${ }^{744}$ Pode-se dizer que o vocábulo ius, já nesse tempo, indicava ações permitidas pela comunidade quiritária em formação: um cidadão que se apropriasse de um objeto ou entrasse na posse de uma parcela de terra com a aprovação da comunidade e seus costumes (mores maiorum) dizia-se agir conforme o ius ou ex iure Quiritium. ${ }^{75}$

Se antes apenas a mansão ancestral estava exclusivamente nas mãos da família, agora as assignações do populus/rex concedem aos colonos o usus exclusivo e provavelmente perpétuo também sobre uma parcela na centúria; até porque está fora de dúvida que o heredium romuleu, de apenas dois iugera (5.072 $\left.\mathrm{m}^{2}\right)$, ${ }^{746}$ não era, como vimos, suficiente para uma família, embora pudesse ser de costume que ao menos esse espaço fosse transmitido aos filhos.

Em conformidade com o modelo colonial e semi-colonial romano, a centúria replica o esquema augural da fundação de Roma, ainda com fortes traços de comunitarismo agrário. Cada adsignatio corresponde a uma transferência de parte da soberania romana ao colono; mas em última análise ela repousa sobre o auctor ou klein-Rex (na terminologia algo hipotética de BEHRENDS), o magistrado conditor, que garante a limitatio como um todo e aquela incidente sobre cada parcela atribuída, em nome do populus, além de assegurar a observância das servidões de passagem (auctoritas omnium rerum!) e a coleta de água pluvial.

O modus atribuído passa a ser visto como imeditamente ligado a uma parcela concreta na centúria, dada a introdução, mesmo primitiva, da agrimensura; o heredium, nesse modelo, continua ligado ao fundus atribuído pela assignatio. Mas o modus mantém-se como padrão da propriedade (usus) atribuída: em caso de

\footnotetext{
${ }^{744}$ Dion. Hal. 10, 1.

745 G. MousourakIS, A Legal History of Rome, London/New York, Routledge, 2007, pp. 19-20. Provavelmente só mais tarde, na fase propriamente histórica do direito, no período decenviral, se podia falar no testemunho dos Quirites (testamentos, mancipationes) como força autoritativa a confirmar negócios e aquisições de propriedade exclusiva (auctoritas Quiritium).

${ }^{746}$ Cf. P. KIDSON, A metrological Investigation, in Journal of the Warburg and Courtauld Institutes 53 (1990), pp. 71-97, para alguns problemas matemáticos envolvendo o iugerum, o heredium, o actus e outras medidas.
} 
conflito, dentro da forma da centúria tem ele tem proteção de natureza pública; a qualquer momento os limites concretos do fundus podem ser revisados tendo em vista o modus original. Além disso, a parcela goza de uma proteção augural que prevalece sobre demarcações privadas.

Nesse sentido, o antecedente costumeiro da regra do usus auctoritas permite a aquisição de mais parcelas na colônia disponibilizadas à apropriação particular, e além disso, permite aos herdeiros, por ocasião da morte do pater, dar continuidade ao usus da parcela atribuída na pessoa do pater (a auctoritas aqui ratifica uma alteração de domínio, além da garantia pública ligada ao modus da adsignatio original, que se tranfere ao herdeiro).

O usus auctoritas incide primordialmente sobre a parcela ideal, e não sobre as demarcações atuais. A ordem de Numa no sentido da demarcação concreta das terras segue a parcela ideal.

\subsection{3. ${ }^{\mathrm{a}}$ Fase - As XII tábuas. Conclusão}

Alguns romanistas e historiadores, inclusive muito recentemente, ${ }^{747}$ têm recusado, sem exame, a idéia de uma usucapio aplicada ao domínio temporário ou não-exclusivo da terra em tempos pré-cívicos ou fundacionais. Argumentam que o ager nas mãos da gens, por exemplo, não podia ser objeto de usucapio pois isso significaria que a parcela passaria, com ele, à esfera do indivíduo - uma noção privatista da aquisição. Semelhantemente ao ocorrido com WEBER, como já discutido, esses autores deixaram provavelmente de notar que a usucapio, por não ter surgido ex nihilo com a legislação decenviral, admite uma forma anterior: o usus ex auctoritate da terra - seja a gens, seja o populus mais tarde -, ou seja, a posse de parcelas segundo um modus agri dependente fortemente de uma garantia comunitária, fruto de um contexto agrário coletivista e só gradualmente afim à idéia de propriedade privada.

$\overline{747}$ S. T. RoselaAR, Public Land in the Roman Republic... cit., p. 22. 
Esse uso diverso da terra é, pensamos, a explicação do emprego da enigmática expressão «usus auctoritas» ao invés de «usucapio» no direito decenviral; e é a razão do seu desaparecimento no direito clássico, vitorioso o vocábulo ususcapio > usucapio que, segundo o modelo exposto no início deste capítulo, expressa a aquisição da propriedade plena pelo usus, em oposição à vetusta aquisição do usus por meio de uma espécie de título (garantido pela autoridade do auctor/conditor, fundador da colônia, por sua vez um representante do rex/populus) ligado a uma adsignatio cada vez mais concreta no que diz respeito a um locus dentro do sistema de limitação augural.

Uma rigorosa percepção dessa distinção - aquisição da propriedade fundamentalmente pelo usus (clássica usucapio) versus aquisição do usus com base na auctoritas de uma instância soberana (arcaica regra usus auctoritas) - é o cerne deste trabalho.

Com isso em vista, consideremos agora o período propriamente histórico da regra do usus auctoritas, que se inicia com a sua positivação escrita na lei das XII tábuas. Seguindo a recomendação rigorosa de L. WITTGENSTEIN - «Ein Befehl ist nur dann vollständig, wenn er Sinn hat, was immer der Fall sein mag. Man könnte auch sagen: Dann ist er vollständig analysiert»,$-{ }^{748}$ procuramos, assentandos nos resultados anteriores, analisar lógica e filologicamente o comando (Befehl) em sentido amplo (veremos adiante a razão de não ser um comando em entido próprio) ínsito no fragmento decenviral.

Segundo nossa reconstrução, eis o aspecto gráfico aproximado da norma: OISSOS AUCTORITAS FVNDOI BIENNIOM ESTOD.

O verbo no final desafia a típica word order herdada pelo latim do protoindo-europeu (PIE) para o imperativo: com ela, ressalta-se o valor modal do verbo com o seu posicionamento no início. Contudo, a sintaxe do latim decenviral utiliza exclusivamente o verbo final para o imperativo, ${ }^{749}$ o que nos leva a concluir que o

748 Philosophische Bemerkungen - Aus dem Nachlaß herausgegeben von Rush Rhees, Oxford, Blackwell, 1964, p. 79.

${ }^{749}$ B. L. M. BAUER, Word Order, in P. BALdi, P. Cuzzolin (ed.), New Perspectives on Historical Latin Syntax 1 - Syntax of the Sentence, Berlin/New York, de Gruyter, 2009, pp. 269, 276. 
estilo legislativo decenviral tem-no como um padrão em proposições/sentenças deônticas, como nos exemplos abaixo: ${ }^{750}$

L. XII tab. I, 1:

Si in ius vocat, <ito>. Ni it, antestamino. lgitur em capito.

Se [alguém] for chamado em juízo, deve ir. Se não for, chame-se testemunha. Então [se e somente se for o caso] ele deve ser capturado.

L. XII tab. I, 2:

Si calvitur pedemve struit, manum endo iacito.

L. XII tab. I, 4:

Adsiduo vindex adsiduus esto. Proletario quis volet vindex esto.

L. XII tab. III, 2:

Post deinde manus iniectio esto.

L. XII tab. III, 7:

Adversus hostem aeterna auctoritas <esto>.
Se ele tentar se desviar ou fugir, seja capturado [tome-se-lhe com as mãos].

Para um proprietário de terras, seja preposto um proprietário de terras. Para o proletário, qualquer um que queira seja preposto.

Em seguida, seja [o réu] preso com as mãos.

Diante do estrangeiro, a auctoritas [dos Quirites] permanece para sempre.

Diante desses exemplos, analisamos a função do imperativo futuro ESTOD > ESTO sob duas perspectivas ou questões: (1) se se trata de uma norma prescritiva ou descritiva, de acordo com a distinção de G. VON WRIGHT, ou de outro caso; e (2) se a hipotética etimologia ESTOD > ES + *TOD pode nos ajudar a entender a introdução do prazo de um ou dois anos - certamente uma relativa inovação decenviral, ao menos como fixação de costumes.

D. MAKINSON chamou a atenção para a diferença entre $(\alpha)$ normas, que não podem ser ditas verdadeiras ou falsas, e $(\beta)$ proposições deônticas, que são

${ }^{750}$ Padrão que aparece muitas vezes em autores antigos; por exemplo em Cat. de agr. cult. 5, 6: aratra vomeresque facito; 5,1 : alieno manum abstineat. 
proposições verdadeiras ou falsas sobre o que é proibido/permitido. ${ }^{751} \mathrm{O}$ problema recua a I. HEDENIUS, que, ao sublinhar essa ambigüidade, ${ }^{752}$ preparou o terreno para G. VON WRIGHT.

Esse último afirma que expressões do mesmo tipo são usadas tanto para enunciar diretamente um comando quanto, em outras ocasiões, para expressar uma proposição que descreve (ou afirma a existência de) uma ação permitida ou proibida. Sua distinção é, portanto, mais precisa - entre "sentenças deônticas interpretadas de modo prescritivo" e "sentenças deônticas interpretadas de modo descritivo".

O comando decenviral descreveria uma norma ou se constituiria como um imperativo direto? Ora, a presença do verbo no imperativo ESTOD atestaria o fato de que se trata de uma "sentença deôntica interpretada de modo prescritivo"; tratarse-ia, mais simplesmente, de uma prescrição pura, como - abstraindo-se a autoridade ou pessoa que prescreve a norma - em «HERES ESTO» e «SACER ESTO».

Mas se a analisamos, pronto percebemos que ela propriamente não prescreve nenhuma ação.

O típico comando vétero-testamentário «não matarás» ${ }^{753}$ dirige ao povo judaico uma proibição expressa; o conteúdo dessa norma é $\sim(P \mu)$, em linguagem deôntica [não é permitido que $\mu$, dado $\mu=$ "matar"]. ${ }^{754}$ A norma "o uso do cinto de

751 Deontic Logic in Computer Science, Workshop $\triangle E O N^{\prime} 08$, Bolonha, 8 a 10 de janeiro de 2008; publicado em D. MAKInson, On a Fundamental Problem of Deontic Logic, In P. MCNAMARA, H. PRAKKEN (eds.), Norms, Logics and Information Systems - New Studies on Deontic Logic and Computer Science, Amsterdam, IOS, 1999, pp. 29-54.

${ }^{752}$ Mais exatamente entre äkta rättssatser (sentenças legais autênticas) e oäkta rättssatser (sentenças legais não-autênticas); cf. Om rätt och moral, Stockholm, Tidens, 1941, pp. 65-66.

${ }^{753}$ Ex. 20, 13: אל חצרת la ti-rəșoh. Repare-se que o verbo já significa «assassinar», matar ilegalmente ou contra o código moral. Omitimos os sinais de vocalização.

${ }^{754}$ As "coisas" que são permitidas, obrigatórias ou proibidas são atos - como propriedades gerais que qualificam atos (e. g., o roubo) ou como casos individuais (e. g., este caso de roubo), embora para efeitos teóricos só a primeira acepção (propriedades que qualificam de atos) seja usada. Esta observação, a terminologia e a concepção de lógica deôntica usadas aqui seguem o trabalho pioneiro de G. VON WRIGHT, Deontic Logic, in Mind 60 (jan. 1951), pp. 1-15; com correções em Deontic Logics, in American Philosophical Quarterly $4^{2}(1967)$, pp. 136-143. Por negação de um ato entende-se o ato que é praticado pelo agente se e somente se (sse) ele não pratica o dito ato; ou seja, se $\alpha$ denota um ato, $\sim \alpha$ denota a negação desse ato (Deontic Logic... cit., p. 2). Adiante, tomando-se o símbolo $P$ como categoria deôntica indefinida ou básica a expressar a idéia de permissão, temos: $P \alpha=$ é permitido que $\alpha ; \sim(P \alpha)=$ não é permitido que $\alpha ; \sim(P \sim \alpha)=$ não é permitido que não- $\alpha$, abreviado para Oa = é obrigatório que $\alpha$ (idem, p. 4). 
segurança é obrigatório» dirigido aos brasileiros que utilizam veículos automotores de quatro rodas de qualquer classe expressa uma obrigação determinada, a saber: $\sim(P \sim \mu)$ [não é permitido que não- $\mu$, sendo $\mu=$ usar cinto de segurança].

Analisemos uma norma decenviral de natureza semelhante, já mencionada acima: "SI IN IUS VOCAT, ITO». Trata-se de uma obrigação condicional: $\alpha$ $\rightarrow \sim(P \sim \beta)$ [se $\alpha$, então $\sim(P \sim \beta)$, sendo $\alpha=$ ser chamado a juízo, e $\beta=$ comparecer em juízo]. Em linguagem natural: ocorrendo que alguém seja chamado em juízo, então não é permitido não comparecer em juízo (a complexidade da formulação leva a ambigüidades que a formalização do preceito permite afastar).

Muito diverso é o caso do imperativo ESTOD>ESTO quando o endereço da norma não é uma pessoa, e nem o seu conteúdo uma ação. No adágio "ADVERSUS HOSTEM AETERNA AUCTORITAS ESTO», o destinatário do imperativo é a aeterna auctoritas, uma entidade puramente conceitual; e não há qualquer ação que se possa indicar (seria um contra-senso).

Por isso se pode afirmar seguramente que não se trata de um comando em sentido próprio, embora seja uma norma, com um destinatário indireto: a comunidade dos Quirites, que aplica a lei e testemunha a sua observância.

Essa é também a conclusão de $\mathrm{H}$. Spiegelberg. O caso que consideramos é de Festsetzung, de uma proposição estatutória. Com ela não se projeta propriamente um estado de coisas - uma conduta direcionada a um sujeito -, mas sim se atribui a um estado de coisas um modo de existência: o da validade (Geltung). ${ }^{755}$

O autor exemplifica esse modo de existência com o uso do imperativo esto na lei das XII tábuas. Nas proposições «UTI LINGUA NUNCUPASSIT, ITA IUS ESTO» $\mathrm{e}$ "HERES ESTO», por exemplo, não temos a instituição de um dever de conduta (Verhaltenspflicht), e por isso não estamos diante de um comando (Befehl). ${ }^{756}$ Temos normas cujo não-cumprimento é impossível: basta que a situação de fato exista para que tenham imediata validade.

\footnotetext{
755 Gesetz und Sittengesetz - Strukturanalytische und historische Vorstudien zu einer gesetzfreien Ethik, Zürich, M. Niehans, 1935, p. 74.

${ }^{756}$ Idem, p. 74, nt. 1.
} 
Por isso cremos que a principal finalidade da norma do usus auctoritas é a fixação da passagem do tempo suficiente para que se considere daí em diante válida a situação autorizadora, segundo instituto jurídico já existente no período prédecenviral. Por que a única situação de fato prevista pela norma é o tempo de usus fundado na pré-existente auctoritas quiritária: dois anos. Nisso a norma diverge radicalmente do preceito "ADVERSUS HOSTEM AETERNA AUCTORITAS ESTO»: aqui temos uma proibição da aquisição do usus pela auctoritas por quem não tem o assentimento dos Quirites (por ser estrangeiro), porque a condição temporal não se satisfaz nunca; o sentido é duplo, porque, por outro lado, o cidadão romano tem a proteção eterna dos Quirites, uma vez que a «propriedade» é vedada aos estrangeiros. O sentido é meramente obstativo. Não tendo auctoritas, o estrangeiro nunca obtém a permissão de possuir parcela de terra delimitada segundo o sistema augural (daí a conhecida origem da propriedade quiritária em imóveis parcelados conforme esse sistema).

A norma do usus auctoritas pode ser descrita assim:

$A_{1} \wedge A_{2} \wedge A_{3} \rightarrow \square U A$, sendo $A_{1}=$ def auctoritas fundi, $A_{2}=$ def cidadania romana, $A_{3}=$ def usus por dois anos; e $U A=_{\text {def }}$ usus-auctoritas fundi, conforme a interpretação $\hat{\mathcal{L}}$, que atribui a cada constante não-lógica do sistema $S:\left\{A_{1} \ldots A_{n}\right\}$ um sentido jurídico ou factual.

Introduzimos o operador $\square$ para indicar que, preenchidas as condições $A_{1} \wedge A_{2} \wedge A_{3}$ (o sinal "^" indica o conectivo lógico "e"), o status constitutivo UA tem lugar imediatamente, necessariamente (o sinal $\square$ é usado convencionalmente como operador modal de necessidade). Evitamos provas e demais definições e axiomas 
que aqui não têm cabida. A conseqüência importante é que, sendo verdadeira a proposição $A_{1} \wedge A_{2} \wedge A_{3}$, necessariamente temos $U A\left(A_{1} \wedge A_{2} \wedge A_{3} \rightarrow \square U A\right) .{ }^{757}$

Esse modelo torna a regra da aeterna auctoritas a rigor desnecessária: pois sem o elemento $A_{2}$ (que implica, no caso do estrangeiro, também a ausência do elemento $A_{1}$ ) a Festsetzung decenviral sobre UA não se aplica: a situação jurídica não se constitui. Pois isso pensamos que a regra da aeterna auctoritas é meramente reforçativa da proibição de usucapião por estrangeiros.

Reforça essa exegese a conjectura de A. SCHERER de que o imperativo do futuro em -tō se apóia na aparição (Hinzutreten) de um advérbio *tōd (ablativo da raiz demonstrativa *tō-) com o sentido de "daqui em diante, então" adicionado ao imperativo sem terminação. ${ }^{758}$ Pensando no exemplo de A. L. SIHLER para legetod, com o sentido de "daqui em diante, reúna", podemos conjecturar um significado ambíguo para o estod em questão: ${ }^{759}$ (1) "daqui em diante, o usus auctoritas se perfaz em dois anos"; (2) "o usus auctoritas passa a existir a partir dos dois anos completos". O critério da ambigüidade é: se o imperativo com o adjunto adverbial estod se refere ao tempo do futuro ou ao presente da edição da legislação. Favorecemos a primeira interpretação (1).

Por fim, resta fixar que a verdadeira inovação da lei decenviral foi, além da introdução do prazo de dois anos, em razão do que ficou dito acima, a peculiaridade da transformação do usus legítimo em suum ex iure Quiritium segundo o locus-Prinzip.

O usus significa nas XII tábuas o mero suum sobre uma parcela demarcada, e a auctoritas é o aspecto testemunhal do ius Quiritium que garante esse suum, agora incidente sobre um locus determinado, embora a demarcação do fundus

\footnotetext{
${ }^{757}$ Lembramos que a maioria dos autores crê - para nós isso só vale para a usucapio pós-decenviral - que a auctoritas só existe depois do prazo de dois anos (portanto segundo a fórmula normativa $A_{2} \wedge$

$A_{3} \rightarrow \square U A$. Em nosso modelo, a partir dos dados históricos de que dispomos, a ocupação de terra sem auctoritas - o que equivale a dizer: a ocupação de uma parcela não suscetível de apropriação quiritária - é contrária ao direito decenviral e pré-decenviral. A auctoritas dos Quirites é justamente o elemento que permite ao cidadão possuir legitimamente e concretizar o seu direito de atribuição quiritária sobre uma parcela ou fundus determinado.

${ }^{758}$ Handbuch der lateinischen Syntax, Heidelberg, C. Winter, 1975, p. 82 (nt. 53 para literatura).

${ }^{759}$ New Comparative Grammar of Greek and Latin, New York, Oxford University, 1995, p. 548.
} 
possa ainda ser revisada segundo o modus original (também segundo um elemento do meum esse ex iure Quiritium).

A autonomia do direito privado opera uma transferência da soberania sobre o solo no ager limitatus et adsignatus sobre os indivíduos, como ficou demonstrado no capítulo anterior. Só agora se pode falar num suum aplicado sobre os fundi - uma espécie de início da propriedade quiritária, com suas peculiaridades arcaicas.

Embora seja legítimo caracterizar a garantia pública sobre o suum como uma auctoritas ex iure Quiritium, pode-se dizer que o seu detentor é já o indivíduo (o auctor fundi); ao alienar o fundus, este responde pelo modus mencionado no nexum e pode ser responsabilizado pela actio de modo agri.

Uma vez que este auctor tem a soberania sobre o fundus, é-lhe permitido aliená-lo sem restrições através do nexum. Por isso quem se apresenta como auctor fundi ao vendê-lo e não o é, responde pela evicção. Mas é impossível dizer que esteja aí a raiz da teoria sobre a existência de uma actio auctoritatis.

Algumas definições podem ser esboçadas a modo de conclusão:

Auctoritas: Anrecht, garantia ou título envolvendo a adsignatio original e seu o modus dentro do sistema de limitação, bem como (do ponto de vista probatório) a cadeia de domínio (ab stirpe auctoritas).

Usus: efetivo domínio sobre solo limitado e demarcado pela terminatio.

Usus auctoritas: conjunção entre os confins do usus (corpóreo) e o Anrecht, aspecto abstrato do suum ex iure Quiritium válido dentro do sistema de limitação (incorpóreo, jurídico).

Auctor: magistrado responsável pela adsignatio que detém, em último termo, a auctoritas e, mais tarde, o próprio titular atual do fundus, que se reporta aos Quirites.

A auctoritas é portanto a garantia do direito individual ao modus; o usus o exercício desse direito nos limites da adsignatio. Como fruto de um alargamento jurisprudencial, esse direito podia se expandir pelo usus, ultrapassando os limites originais da adsignatio, atingindo por exemplo novas parcelas da centúria. Mas quem 
não fosse cidadão romano, desprovido de título, não podia exercer o usus legitimamente.

$\mathrm{Na}$ hipótese de conflito, a auctoritas é relativa à titularidade sobre o modus dentro do sistema de limitação, e o usus permite a confirmação dos confins concretos desse modus em ato.

A função precípua do adágio OISSOS AVCTORITAS FVNDOI BIENNIOM ESTOD no período decenviral é, por fim, transformar um direito de participação em usus legítimo sobre um fundus delimitado - o que se traduz numa integração ou continuação legítima do usus. 


\section{Índice de fontes ${ }^{760}$}

\section{ULPIANI REGULAE}

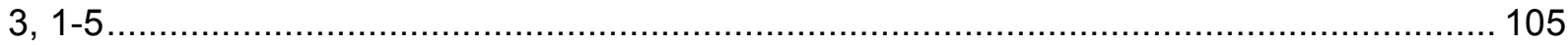

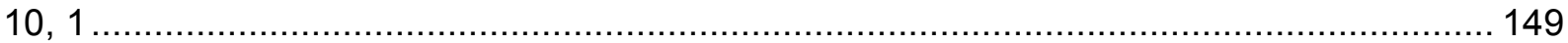

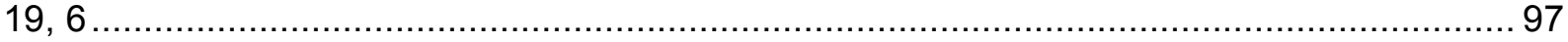

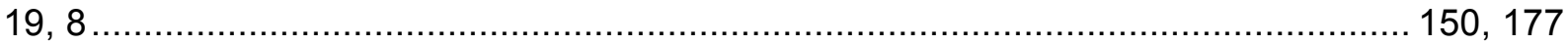

\section{FONTES LITERÁRIAS}

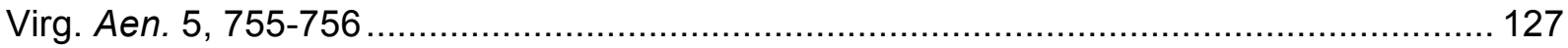

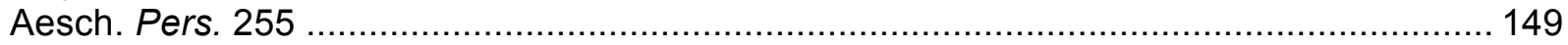

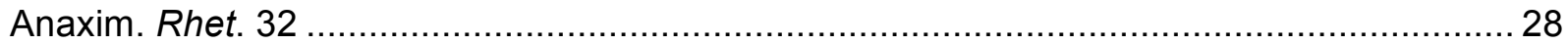

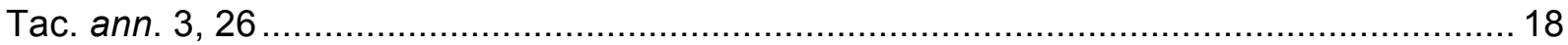

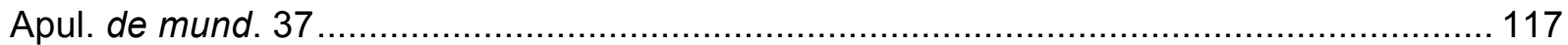

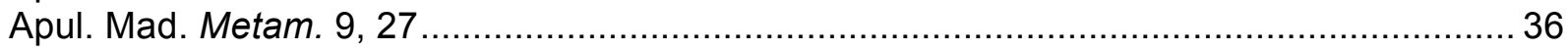

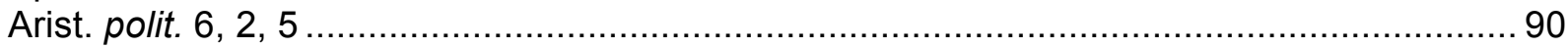

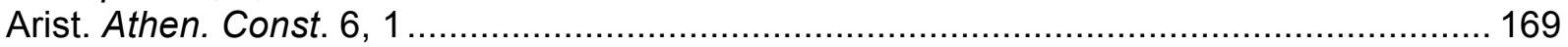

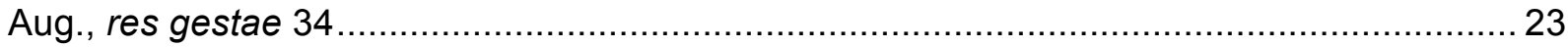

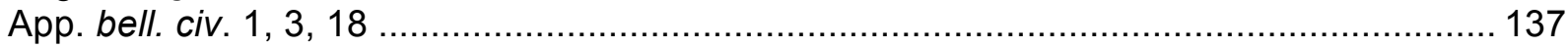

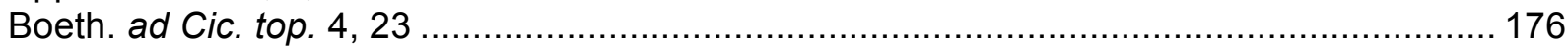

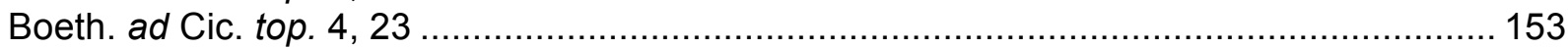

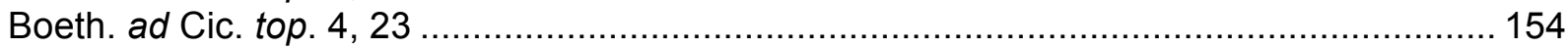

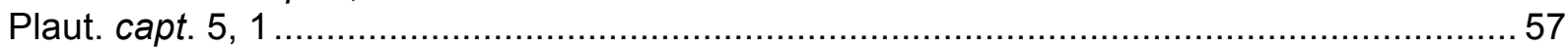

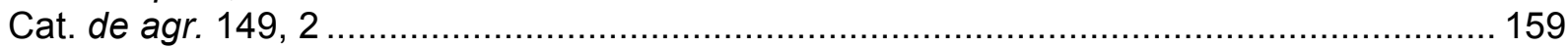

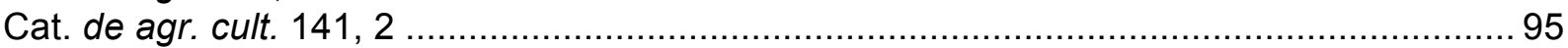

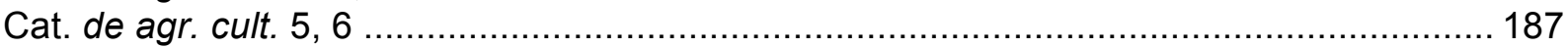

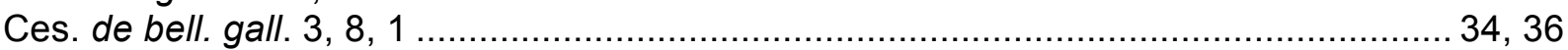

Ces. de bell. gall. 7, 30 ........................................................................................ 34

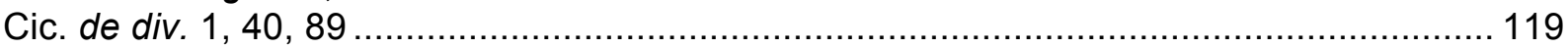

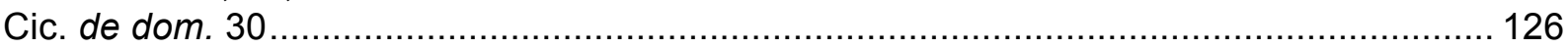

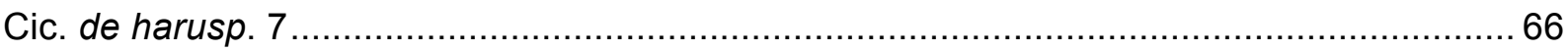

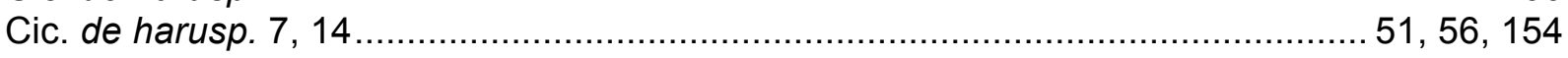

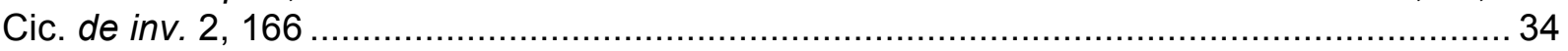

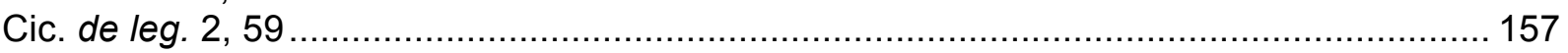

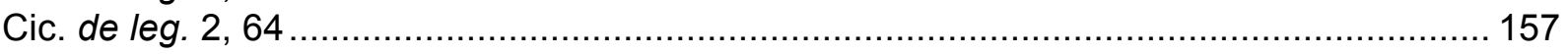

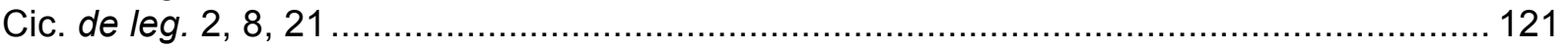

${ }^{760}$ Sobre abreviaturas. Seguimos as abreviaturas comuns no meio científico - em direito romano e estudos clássicos. Nesse meio, as obras mais importantes não costumam vir acompanhadas de uma lista correspondente de autores e obras abreviados. Omitimos uma lista de abreviaturas porque, com exceção das obras clássicas, não abreviamos termos ou títulos em nosso trabalho; só o fizemos com respeito aos nomes de revistas e obras de referência mais conhecidas. Recomenda-se o manual de M. KASER citado na bibliografia final, bem como a monografia de F. J. CASINOS MORA, La noción romana de auctoritas y la responsabilidad por auctoritas, Granada, Comares, 2000, que traz uma lista completa, na medida do possível, de correspondências para nomes e obras do corpus literário latino e grego. 
Cic. de leg. agr. 3, 7, 10-11

.91

Cic. de off. 1, 12, 37

$62,153,154$

Cic. de off. 3, 16, 65

52,154

Cic. de off., 1, 37, 11

46

Cic. de re publ. 2, 14, 26

88

Cic. de re publ. 2, 33

81,85

Cic. de re publ. 2, 36-37

156

Cic. epist. ad fam. 11, 27, 8

Cic. in Verr. 2, 2, 31

Cic. leg. 3, 10 .

Cic. Phil. 2, 40, 102

Cic. pro Balb. 38

Cic. pro Balb. 46

Cic. pro Balb. 8

Cic. pro Caec. 19, 54

Cic. pro Caec. 26, 74

$62,153,154,161$

Cic. pro Caec. 56

72,154

Cic. pro Caec. 74

Cic. pro Mur. 12, 26

118,152

passim

Cic. pro Mur. 2, 3

$53,54,154$

Cic. pro Sest. 42, 91

110

Cic. pro Sull. 33

170

Cic. top. 10, 45 .

$53,54,154$

Cic. top. 12

85

Cic. top. 4,23

46,62

Cic. top. 4, 3 ....

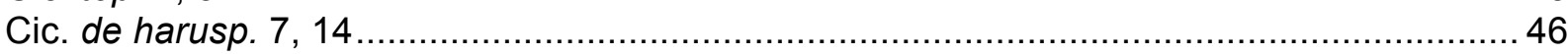

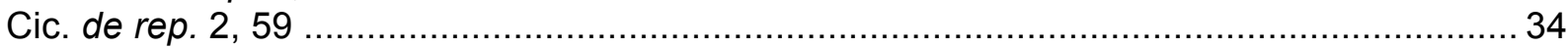

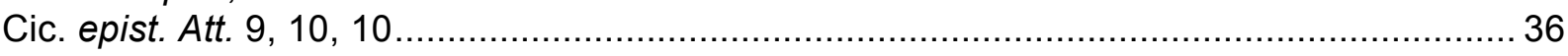

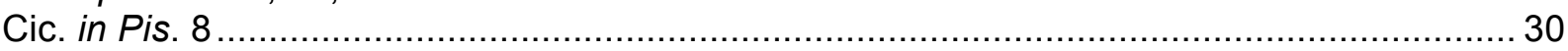

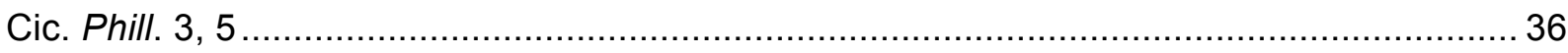

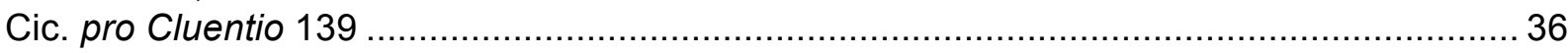

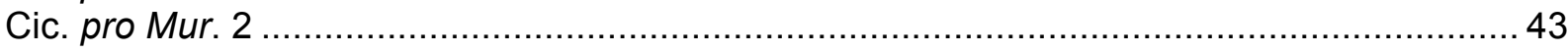

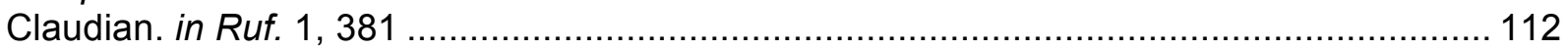

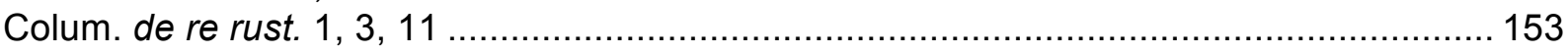

Plaut. Curc. 4, 2, 12 ....

Plaut. Curc. 4, 2, 490

63,154

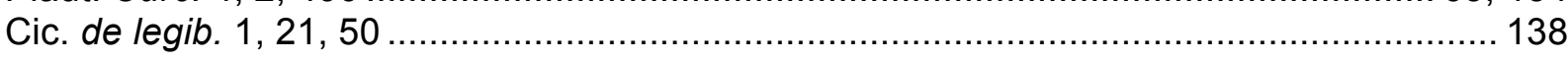

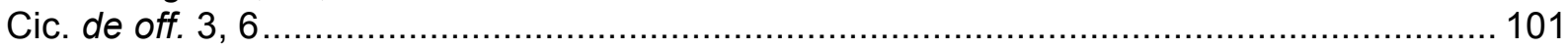

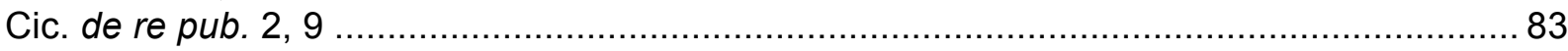

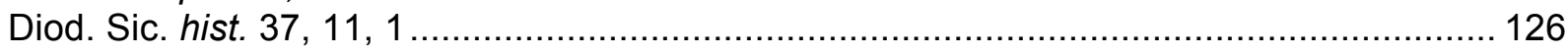

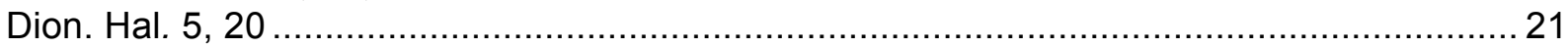

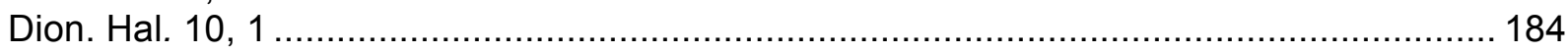

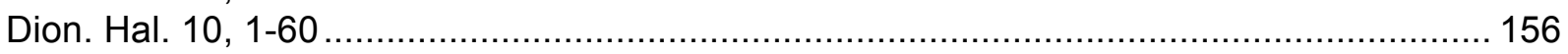

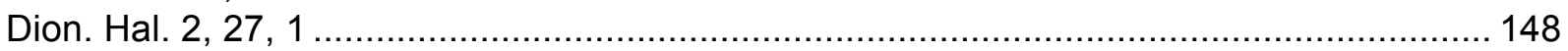

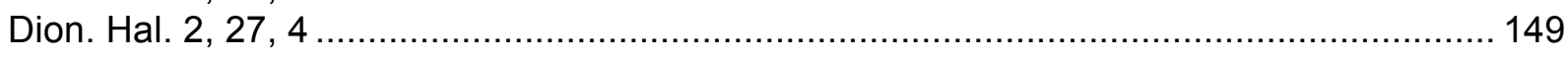

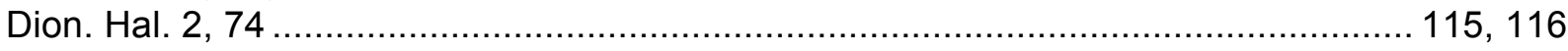

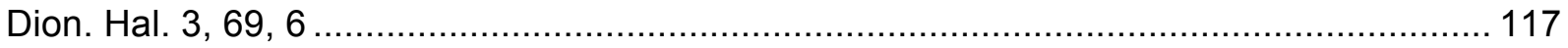

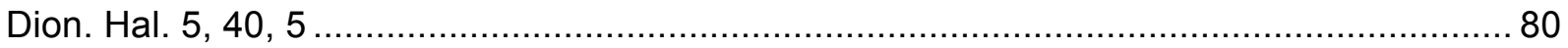

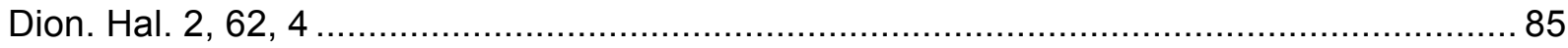




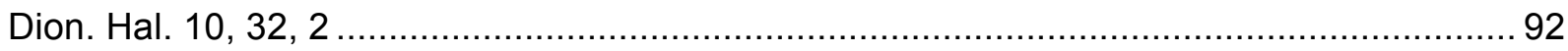

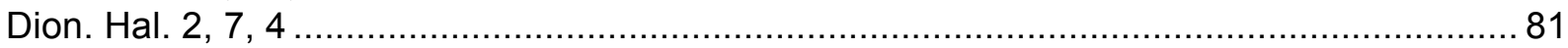

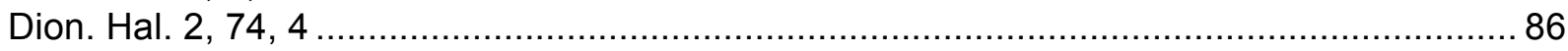

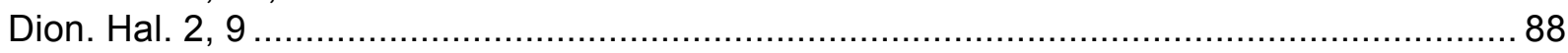

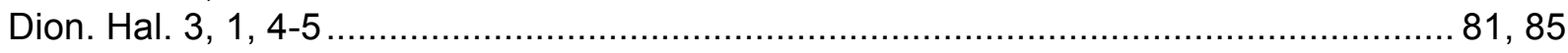

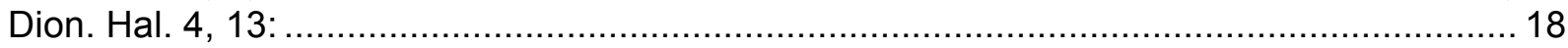

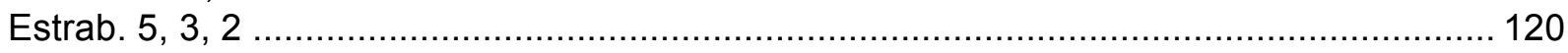

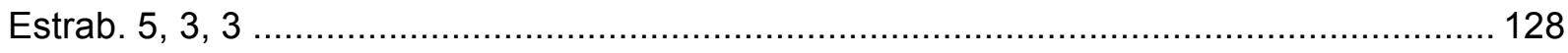

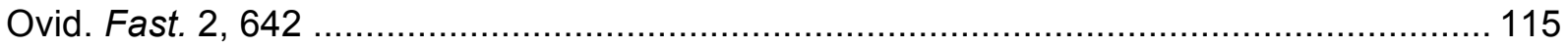

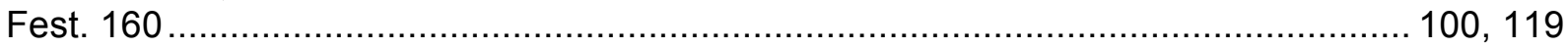

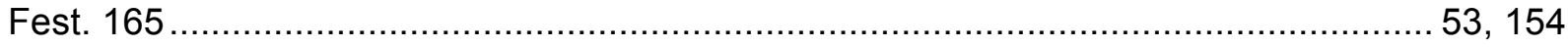

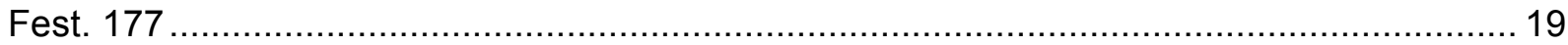

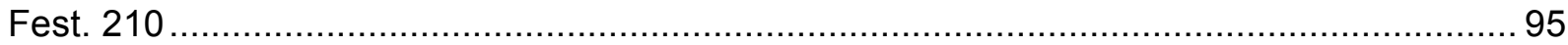

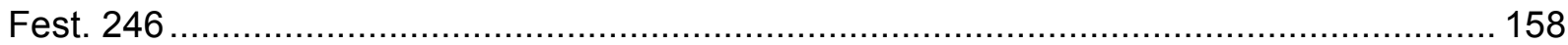

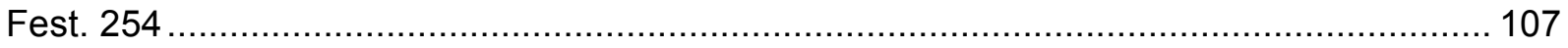

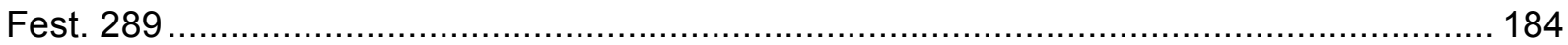

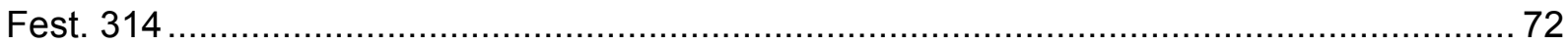

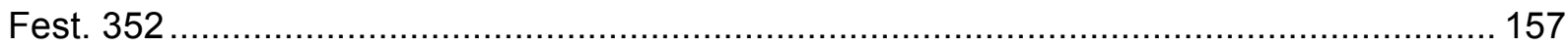

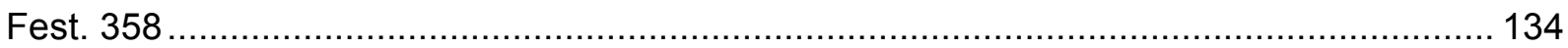

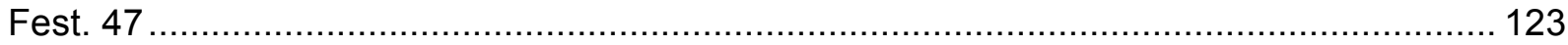

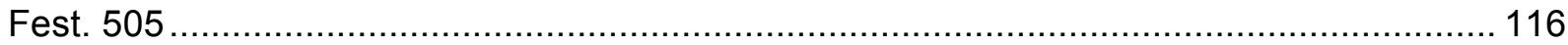

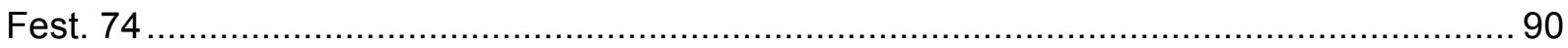

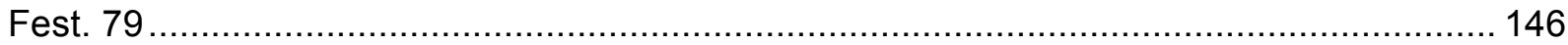

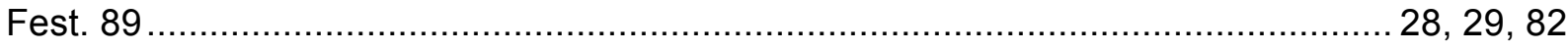

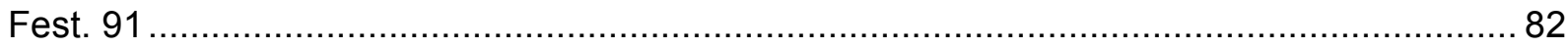

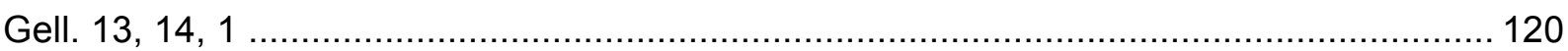

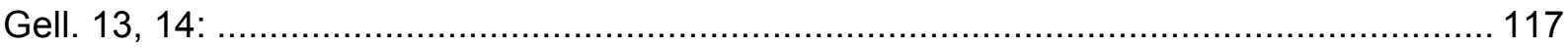

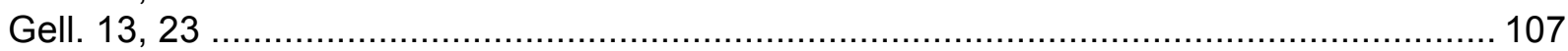

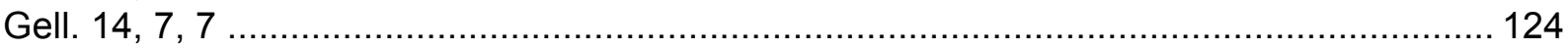

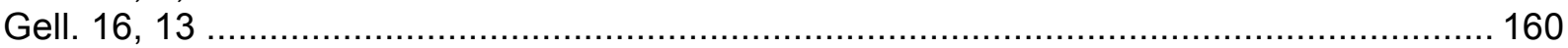

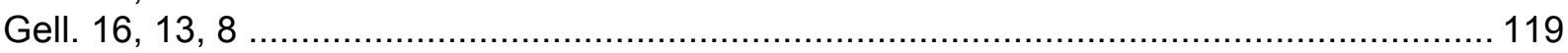

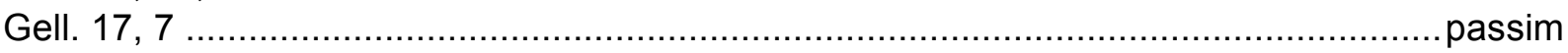

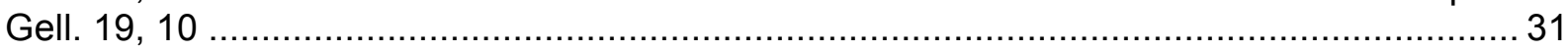

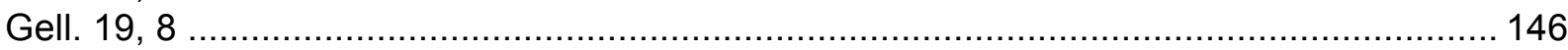

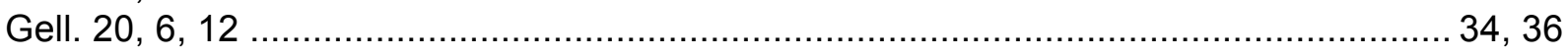

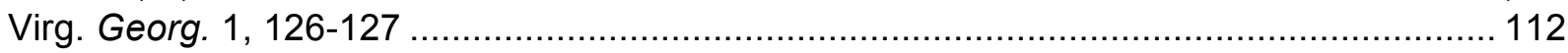

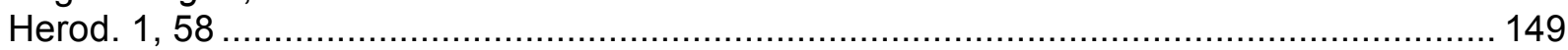

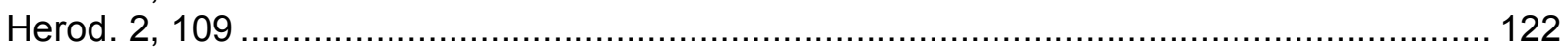

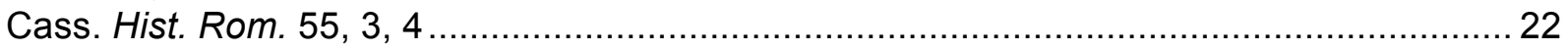

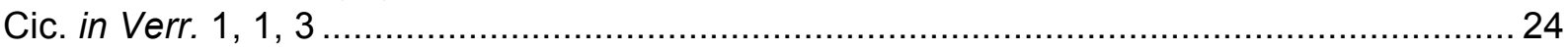

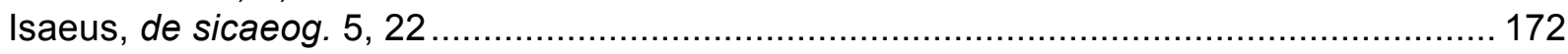

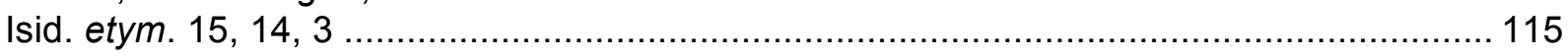

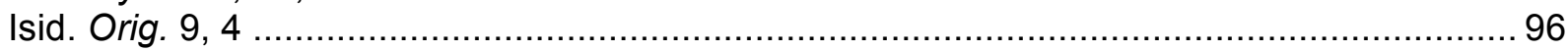

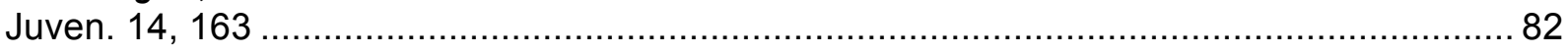

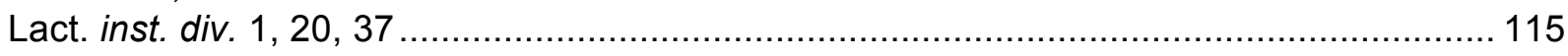

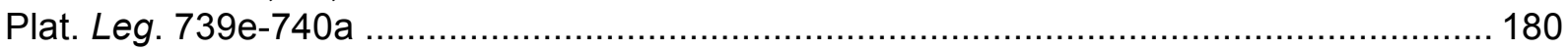

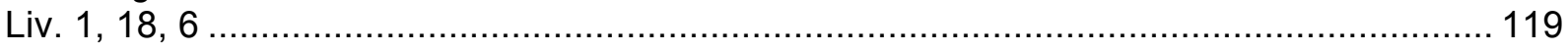

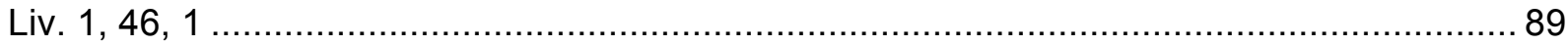

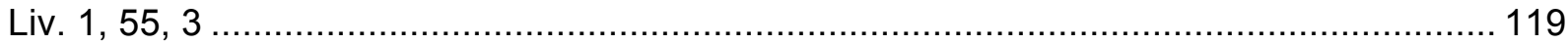

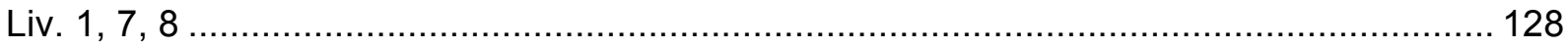




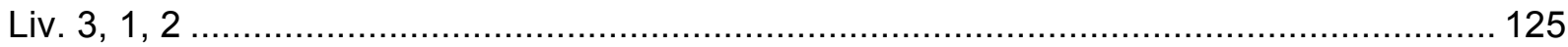

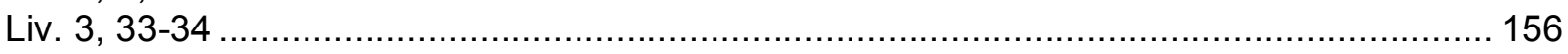

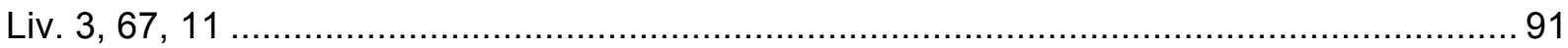

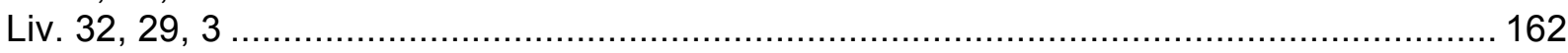

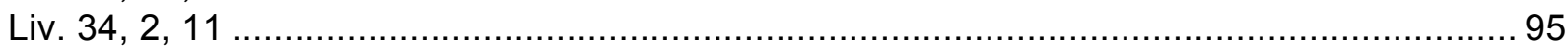

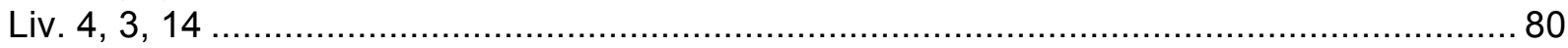

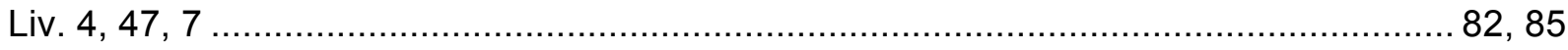

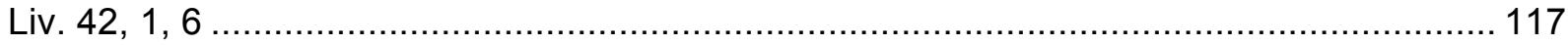

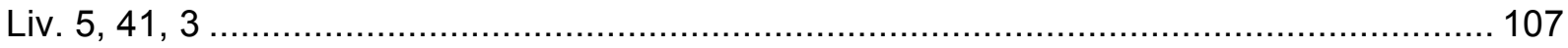

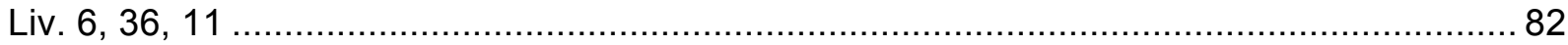

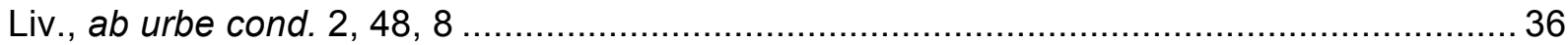

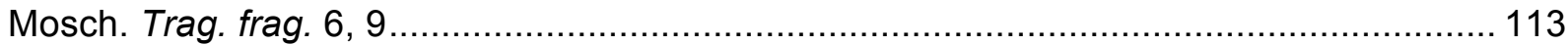

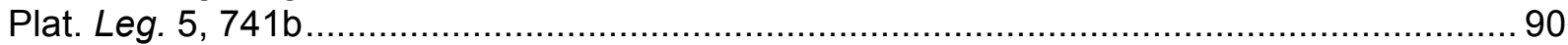

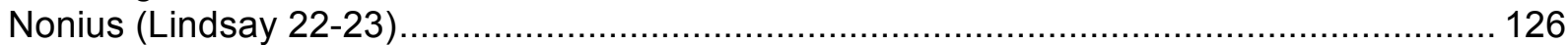

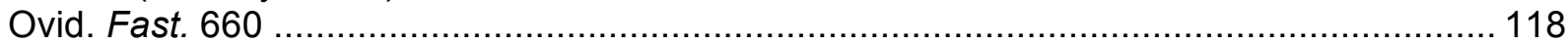

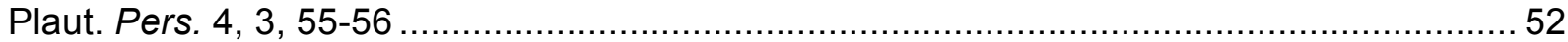

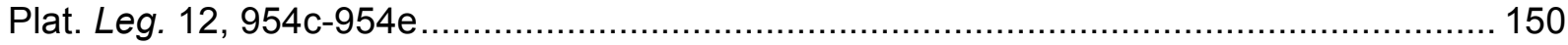

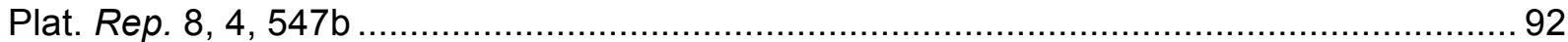

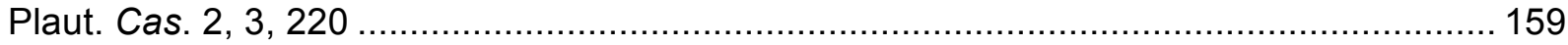

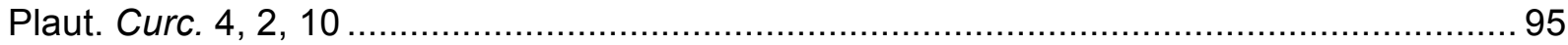

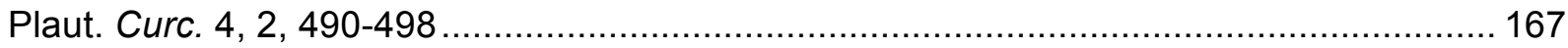

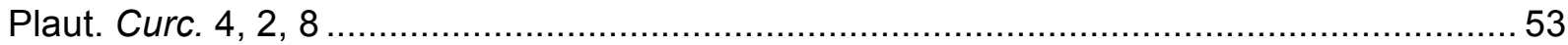

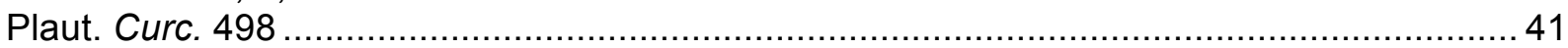

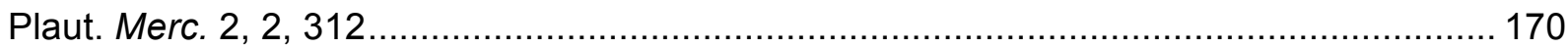

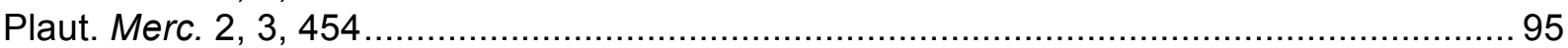

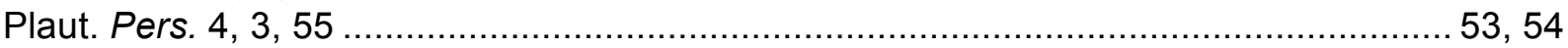

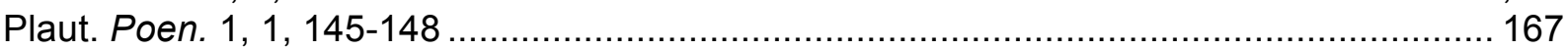

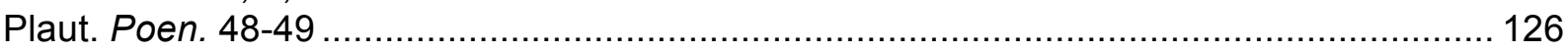

Plaut. Rud. 4, 3 .

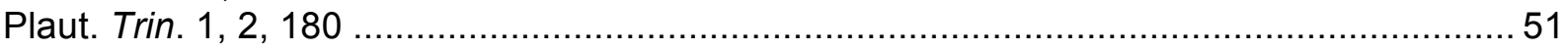

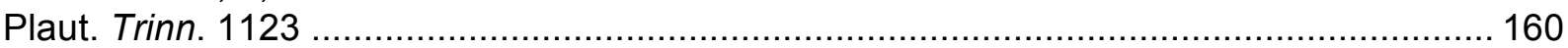

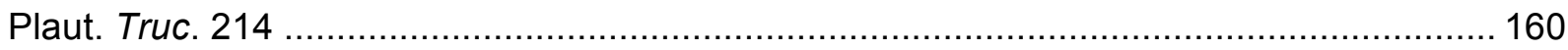

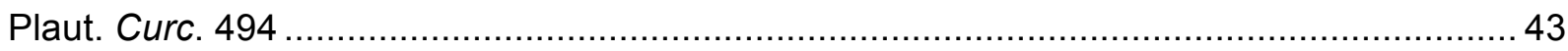

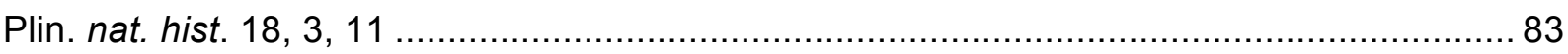

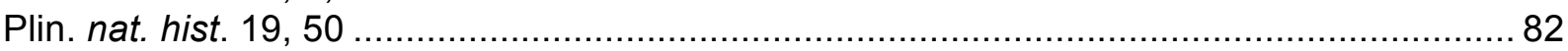

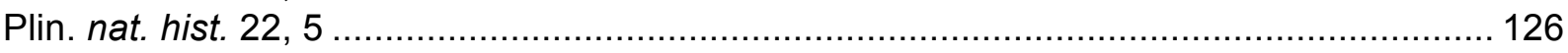

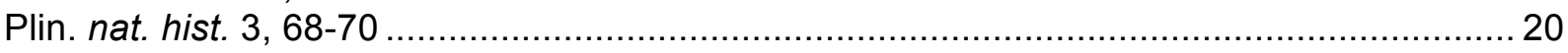

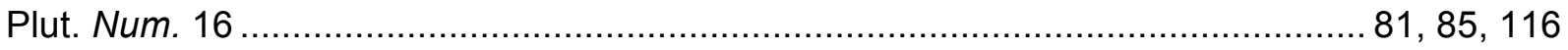

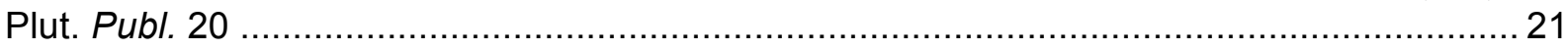

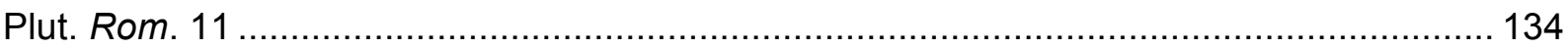

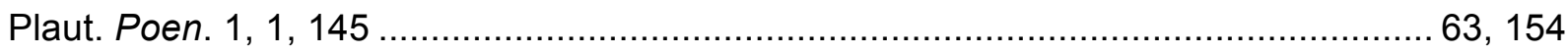

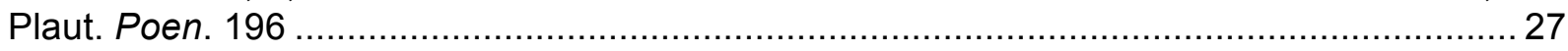

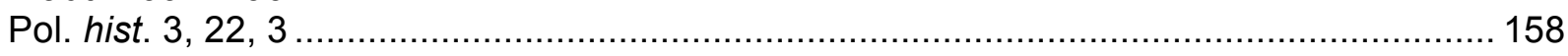

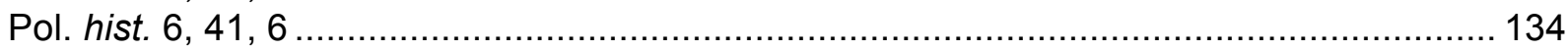

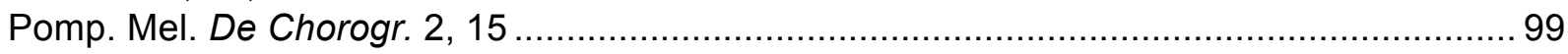

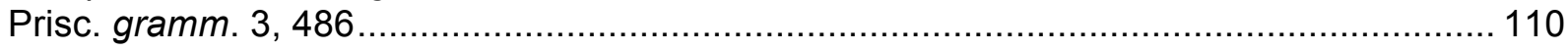

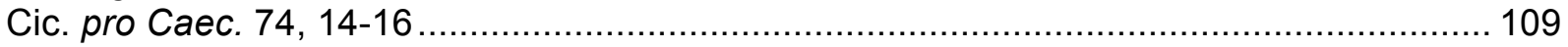

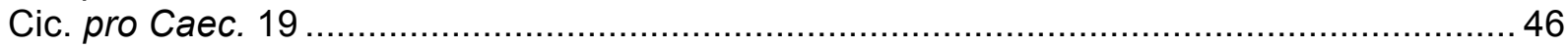

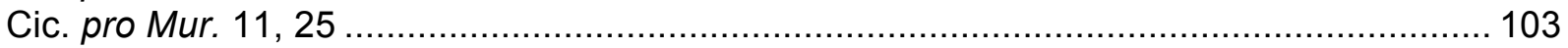

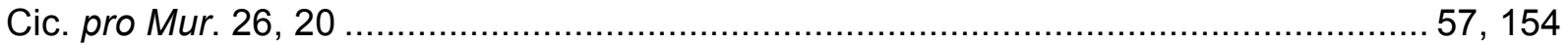




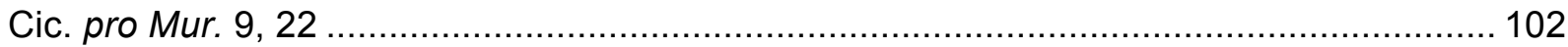

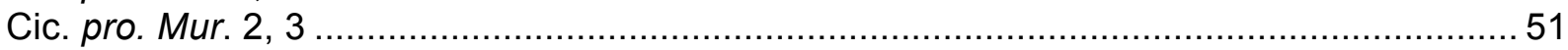

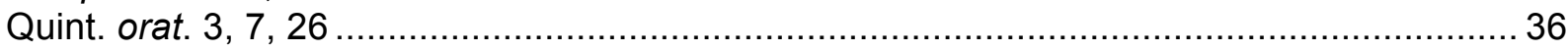

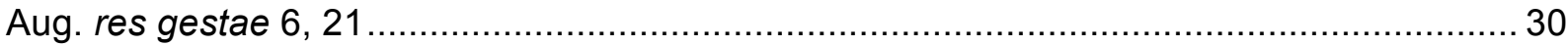

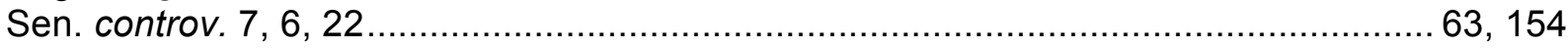

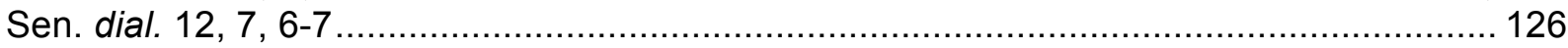

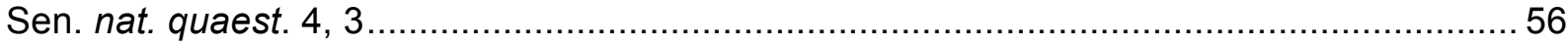

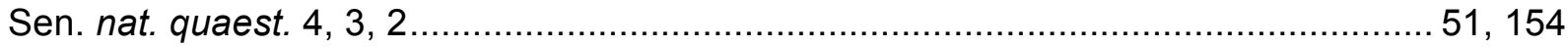

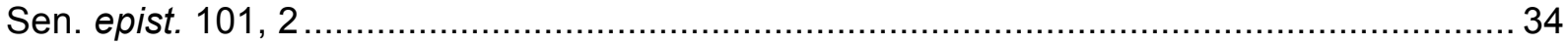

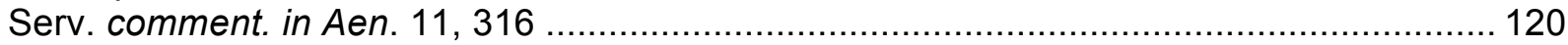

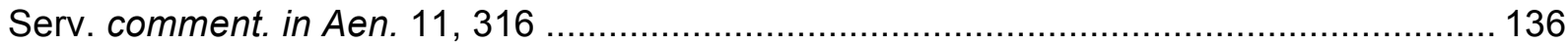

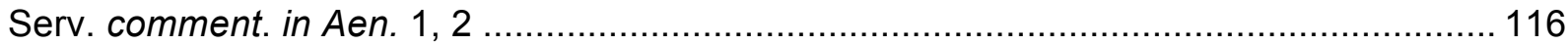

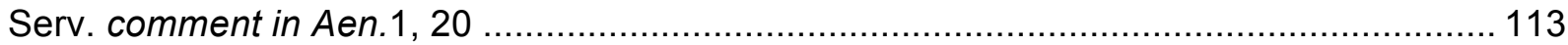

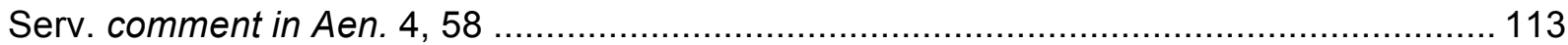

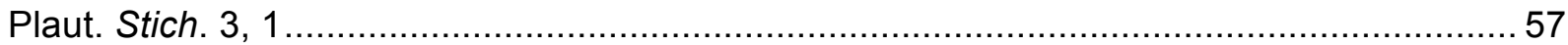

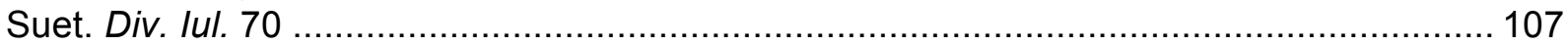

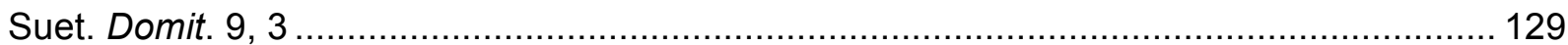

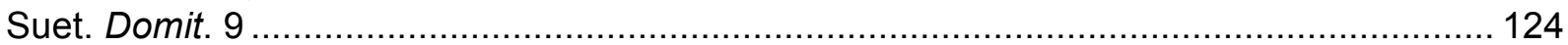

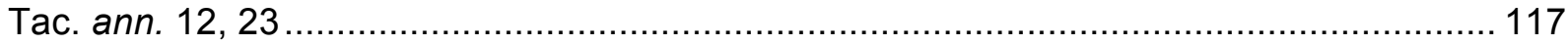

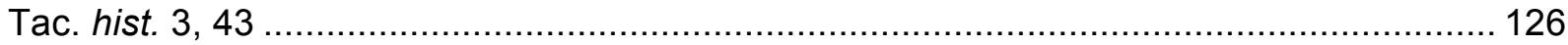

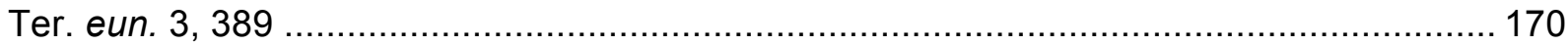

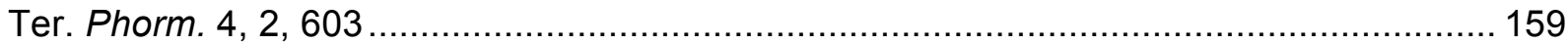

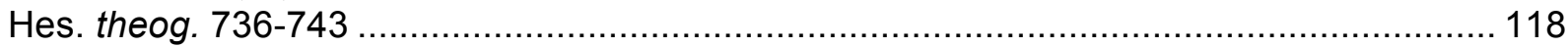

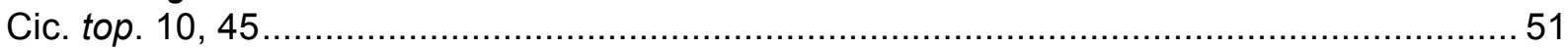

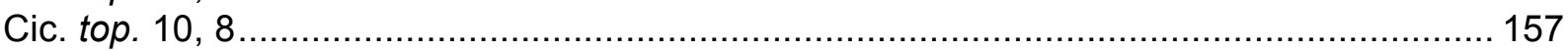

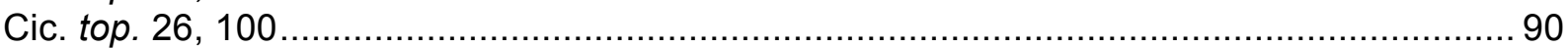

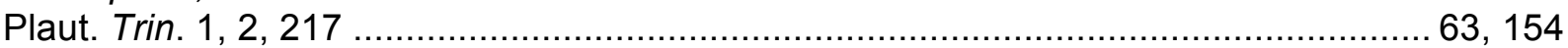

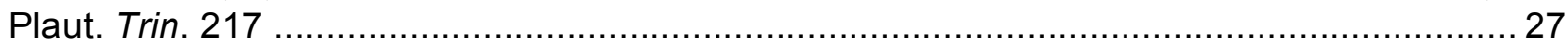

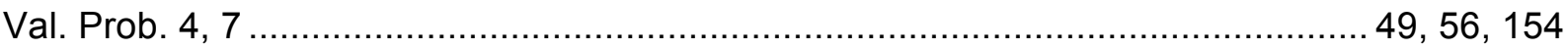

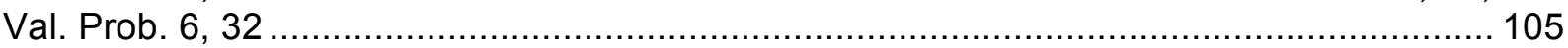

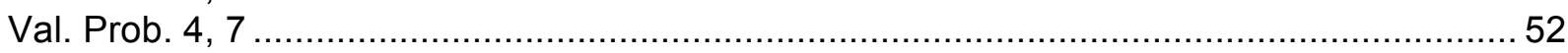

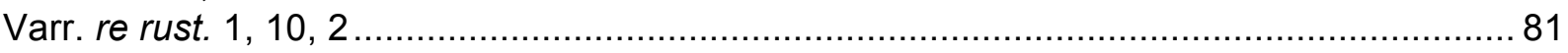

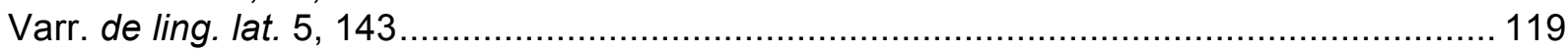

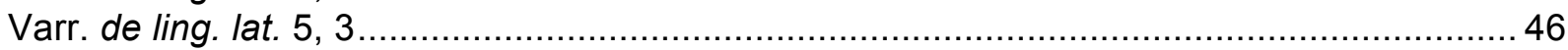

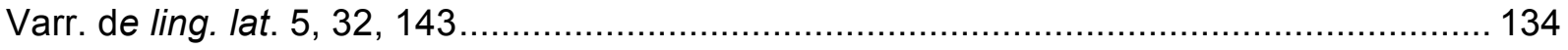

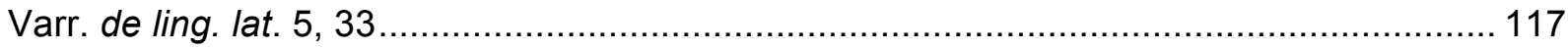

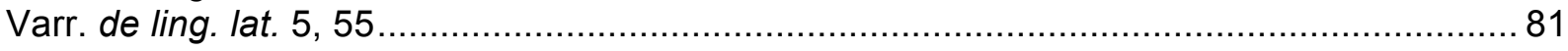

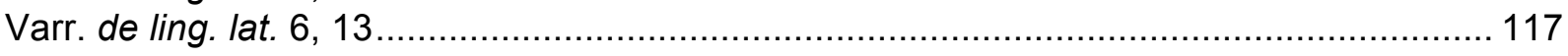

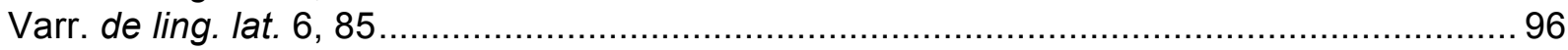

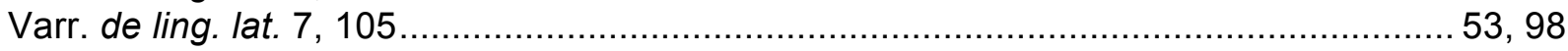

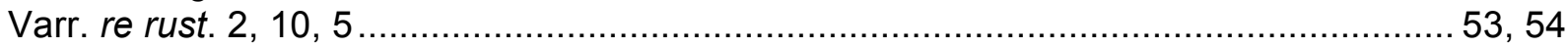

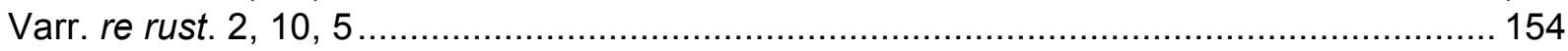

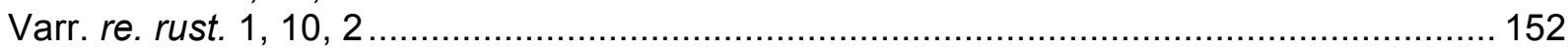

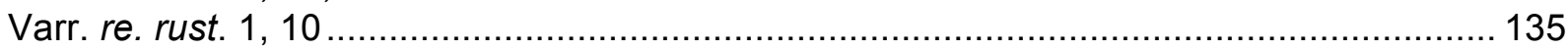

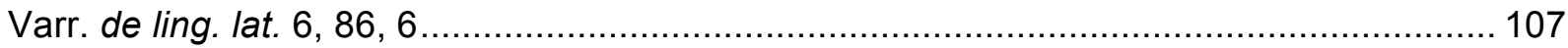

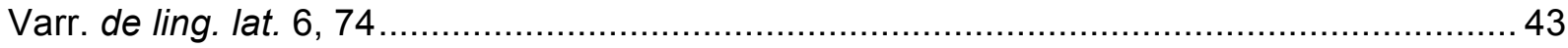

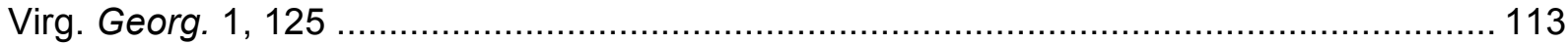

\section{CÓDIGO DE HAMMURABI}

$\S 9$ 


\section{CORPUS INSCRIPTIONUM LATINARUM}

I

\section{DIGESTO}

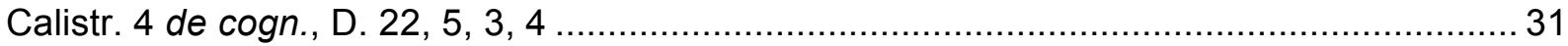

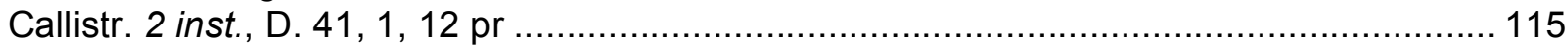

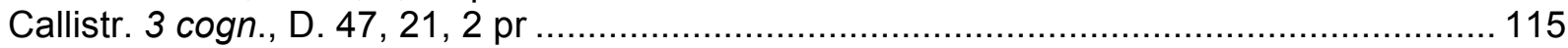

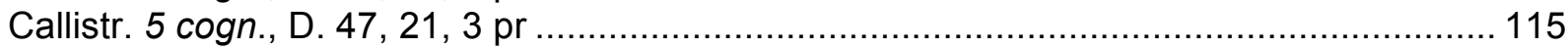

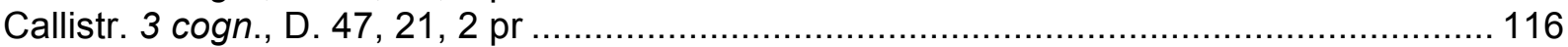

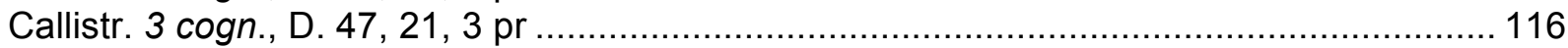

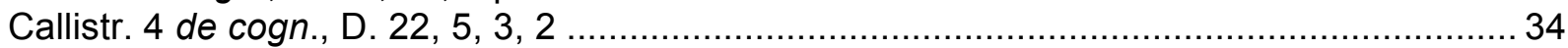

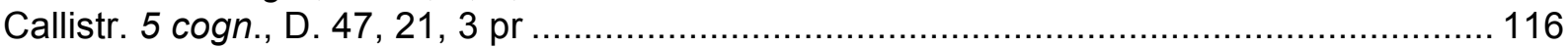

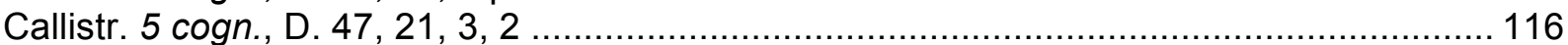

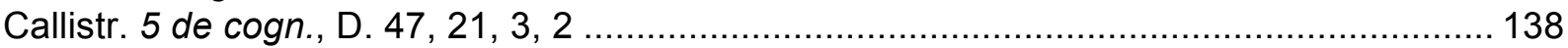

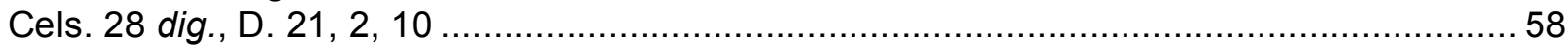

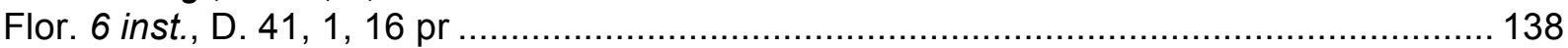

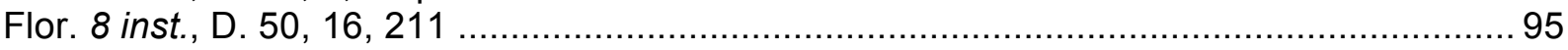

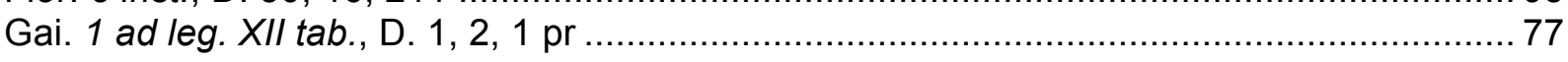

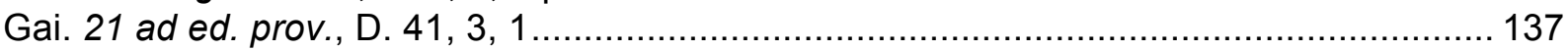

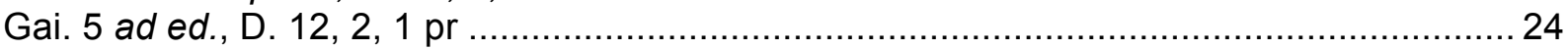

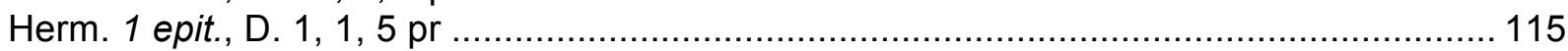

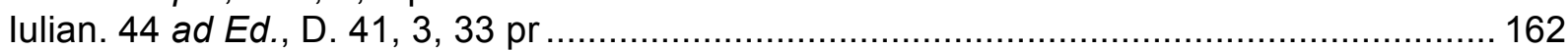

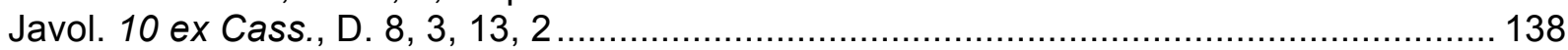

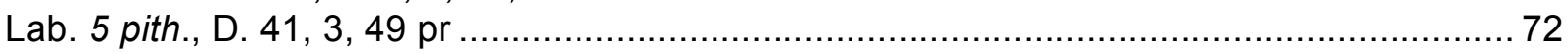

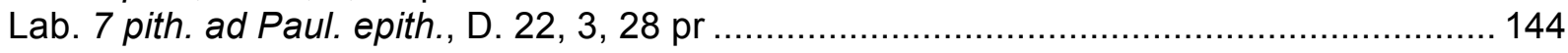

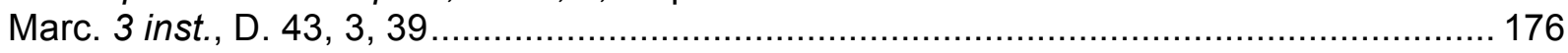

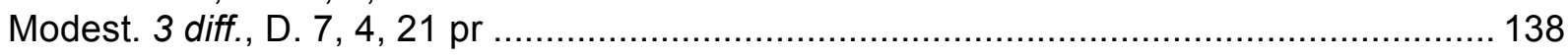

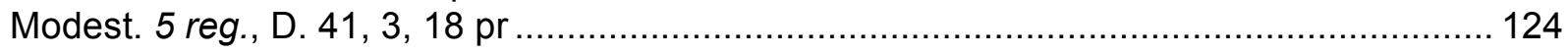


Modest. 8 reg., D. 47, 21, 1 pr

Modest. 11 pandect., D. 10, 1, 7

143,145

Modest. 5 pandect., D. 41, 3, 3

Modest. 5 resp., D. 19, 1, 39 pr

Modest. 8 reg., D. 47, 21, 1 pr....

Pap. 2 definit., D. 1, 1, 7 pr

Pap. 2 resp., D. 10, 1, 11 pr.

Paul. 11 ad PI., D. 50, 17, 175, 1

Paul. 23 ad Ed., D. 10, 1, 4, 5

Paul. 23 ad Ed., D. 10, 1, 4, 5, 1

Paul. 3 resp., D. 10, 1, 12 pr.

Paul. 38 ad ed., D. 26, 1, 1 pr

Paul. 49 ad Ed., D. 39, 3, 2 pr

Paul. 49 ad Ed., D. 39, 3, 2, 8

Paul. 5 ad Sab., D. 18, 6, 7, 1

Paul. 5 ad. Sab., D. 19, 1, 4, 1

Paul. 54 ad Ed., D. 41, 2, 1 pr

Paul. 54 ad Ed., D. 41, 2, 1, 3

Paul. 54 ad Ed., D. 41, 2, 3, 2.

Paul. 54 ad ed., D. 41, 3, 4, 6

Pomp. 26 ad. Sab., D. 45, 1, 5

Pomp. 5 Sab., D. 23, 2, 8

Pomp. ench., D. 1, 2, 2, 1

Pomp. ench., D. 50, 16, 239, 8

Pomp. ench., D. 1, 2, 2, 24

Pomp. ench., D. 1, 2, 2, 38

Scaev. 2 dig., D. 4, 8, 44 pr

Scaev. 5 dig., D. 13, 7, 43 pr.

Scaev. 7 dig., D. 19, 1, 52, 3

Scaev. 5 dig., D. 13, 7, 43 pr

Scaev. 5 dig., D. 13, 7, 43 pr

40,64

Ulp. 1 Inst., D. 1, 1, 4

95

Ulp. 1 Sab., D. 27, 10, 1 pr

Ulp. 14 ad. ed., D. 5, 3, 5, 2

Ulp. 2 ad ed., D. 1, 12, 3 pr.

Ulp. 29 ad. Sab., D. 21, 2, 17

Ulp. 30 ad ed., D. 21, 2, 4 pr

Ulp. 6 opin., D. 10, 1, 8 pr

Ulp. 60 ad ed., D. 43, 17, 3, 4

Ulp. 68 ad ed., D. 43, 12, 1, 22

Ulp. 68 ad ed., D. 43, 12, 1, 6-7

Ulp. 69 ad ed., D. 50, 16, 60 pr.

Ulp. 7 Sab., D. 29, 2, 8 pr

\section{INSTITUTAS DE GAIO (GAI.)}

1,121

$1,167,5$ 


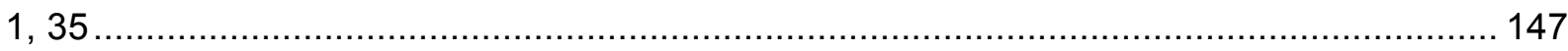

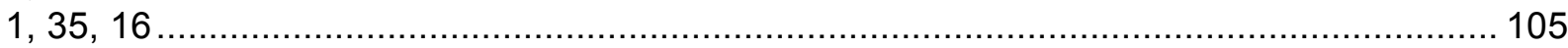

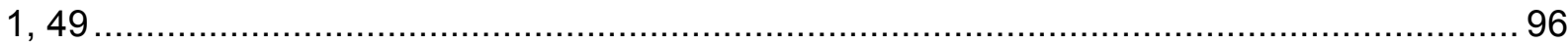

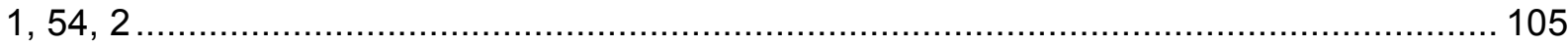

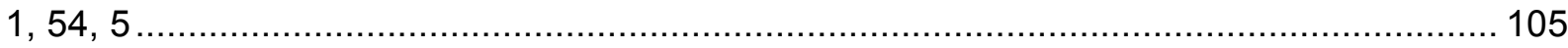

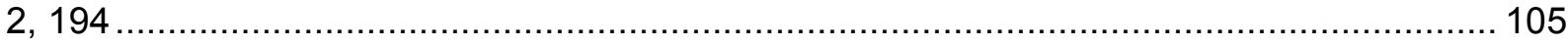

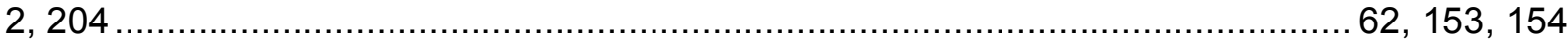

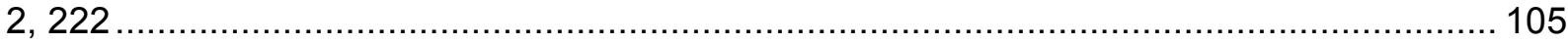

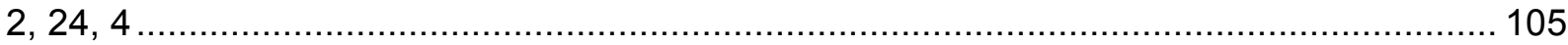

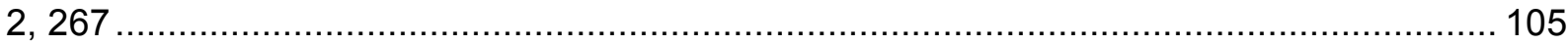

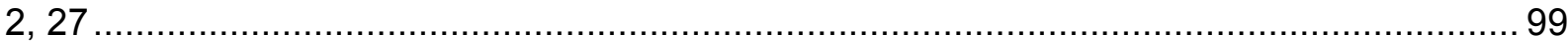

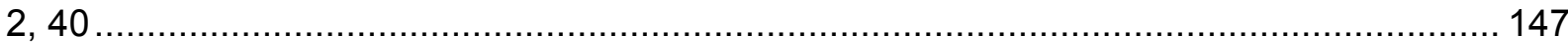

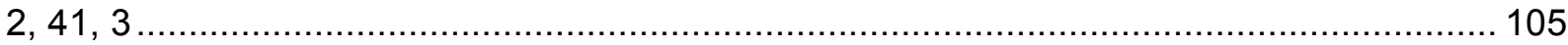

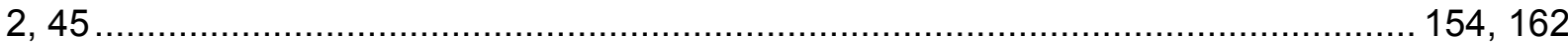

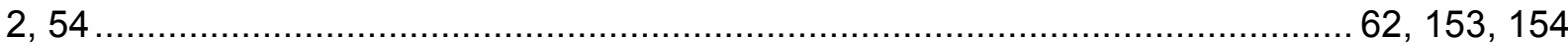

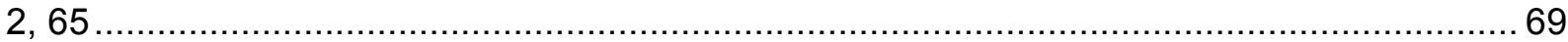

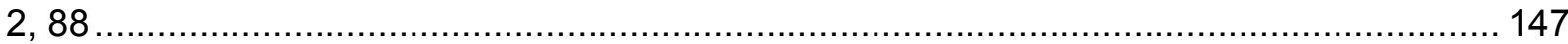

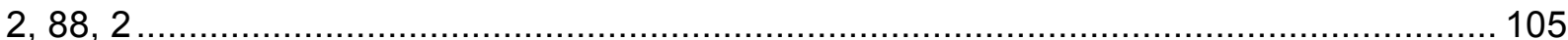

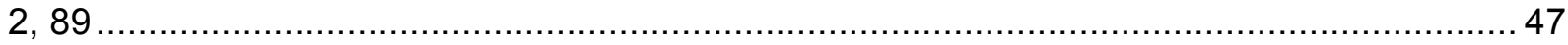

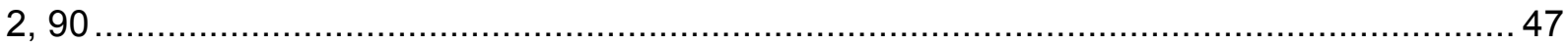

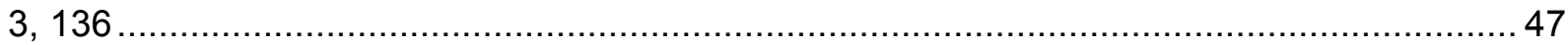

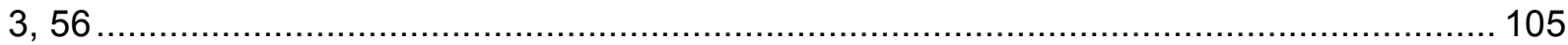

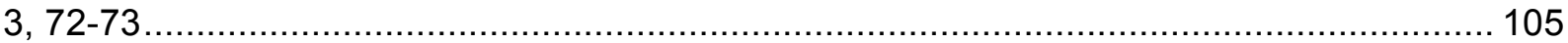

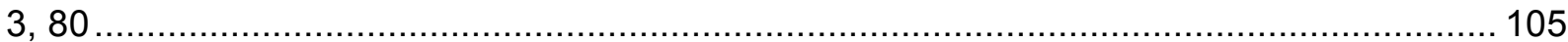

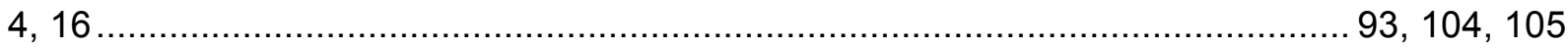

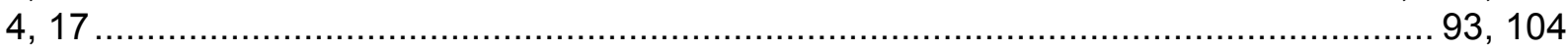

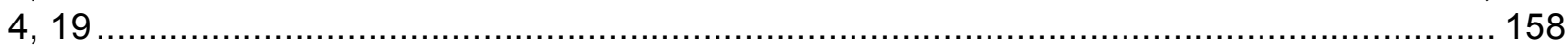

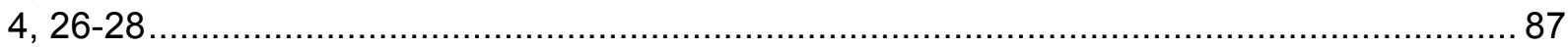

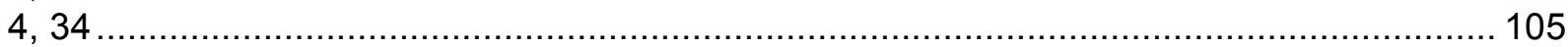

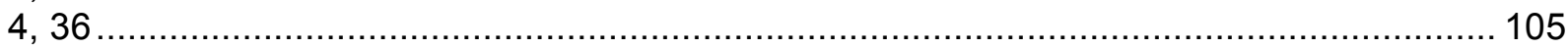

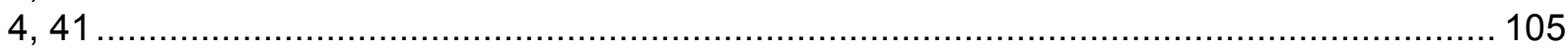

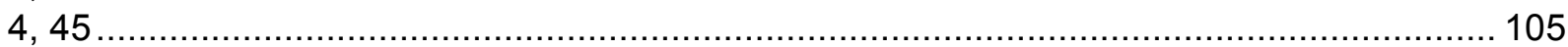

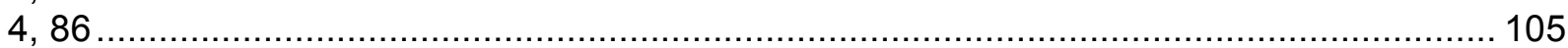

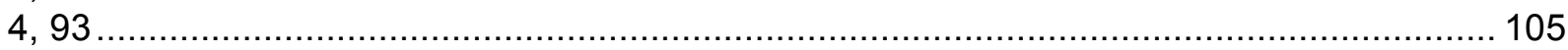

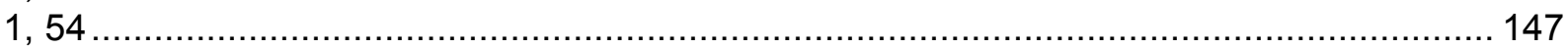

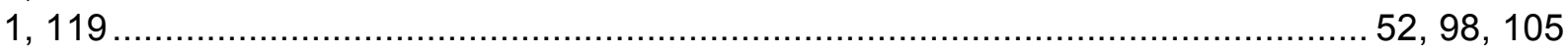

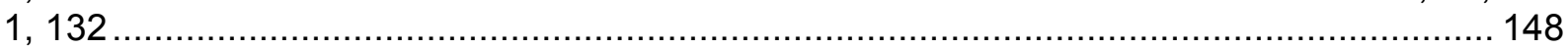

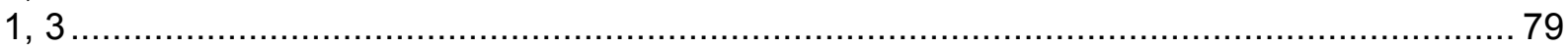

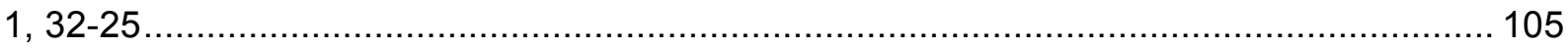

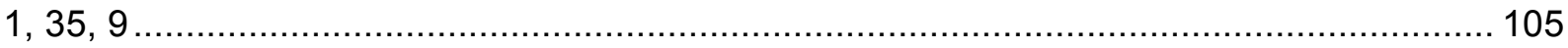

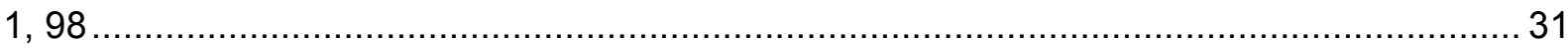

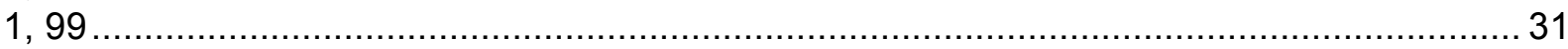

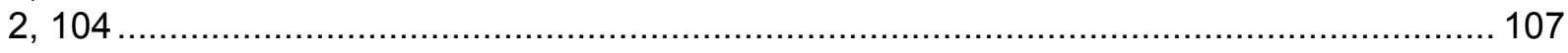

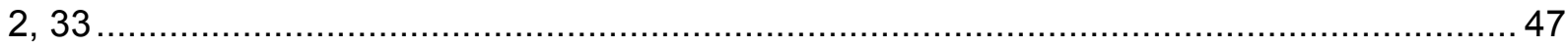

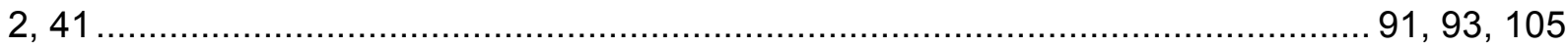

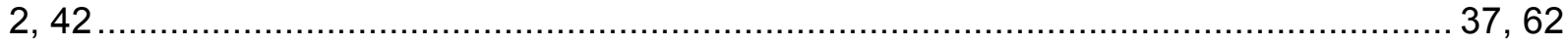

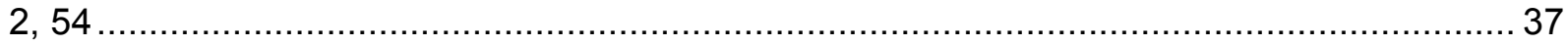

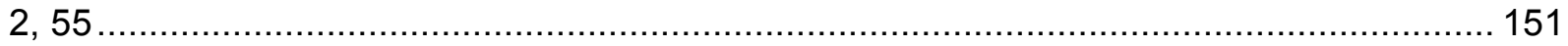

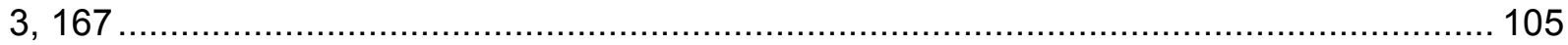

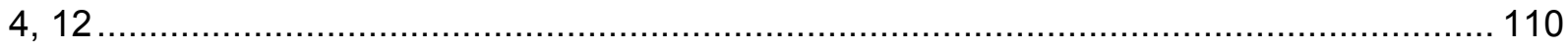




\section{LEX XII TABULARUM}

I, 1 (

I, 2 (n)

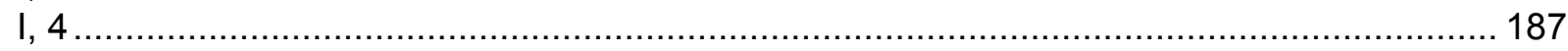

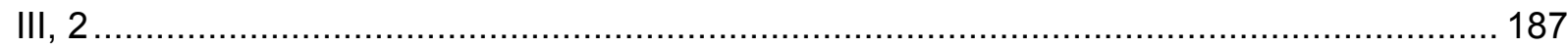

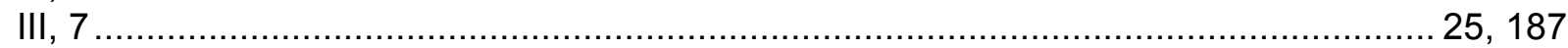

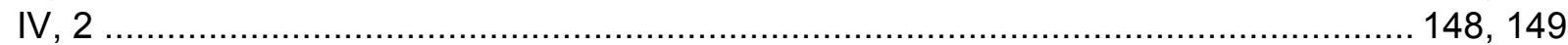

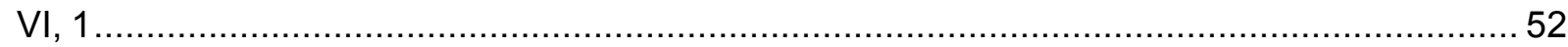

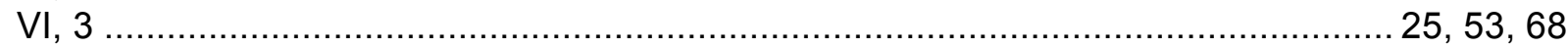

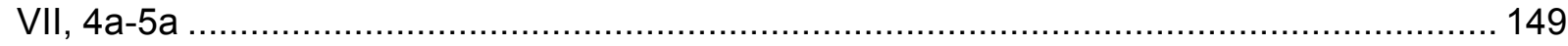

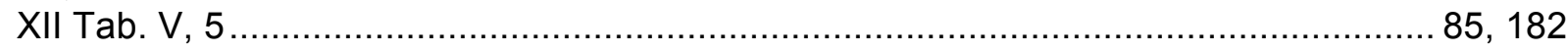

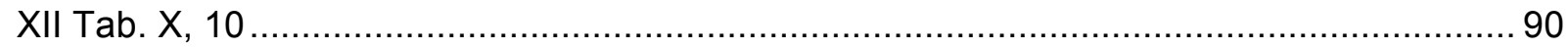

\section{TABULAE IGUVINAE}

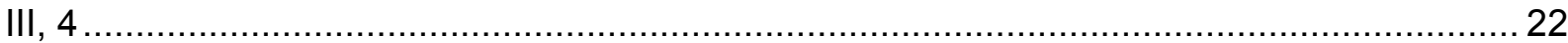

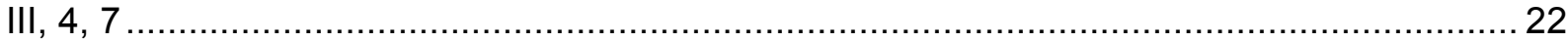

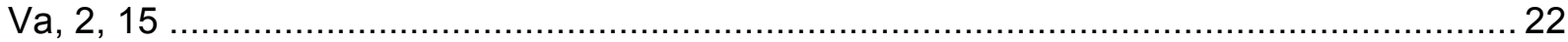

\section{FONTES SÂNSCRITAS}

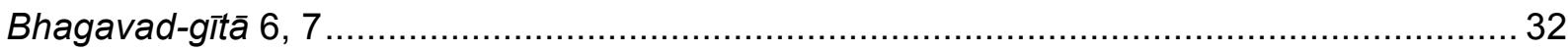

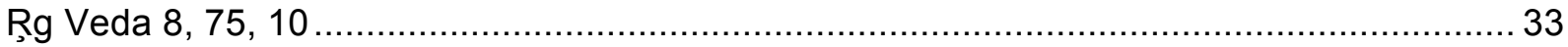

\section{INSTITUTAS DE JUSTINIANO (JUST.)}

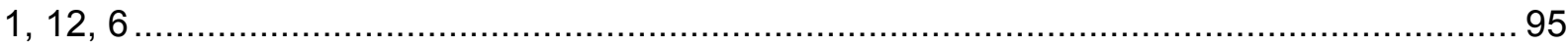

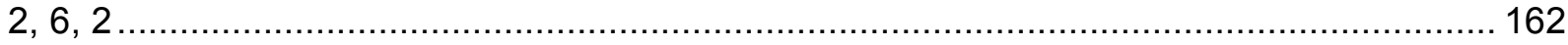

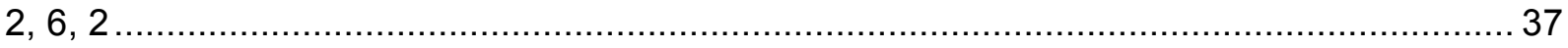

\section{INSTITUTAS DE TEÓFILO (THEOPH.)}

2,6

2,6

\section{FRAGMENTA VATICANA}

Pap. Vat. 10

\section{PAULI SENTENTIAE (PS)}

PS. $1,17,4$

PS. 2, 17, 1-3

PS. 5, 22, 2b

PS. 2, 17, 1

PS. 2, 17, 1 e 3

PS. $2,17,3$

PS. $5,4,6$

\section{LACHMANN (RÖMISCHE FELDMESSER)}

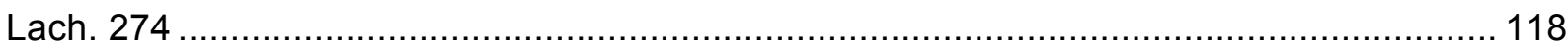




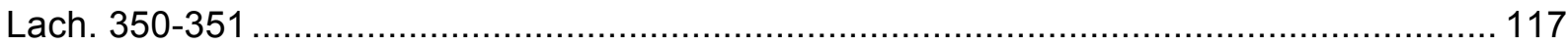

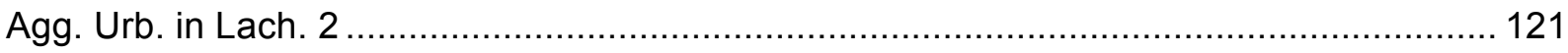

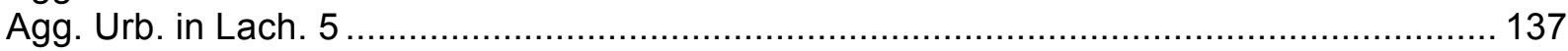

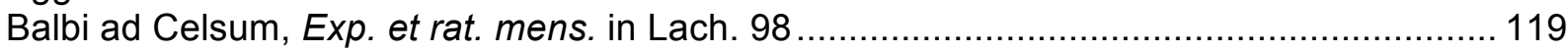

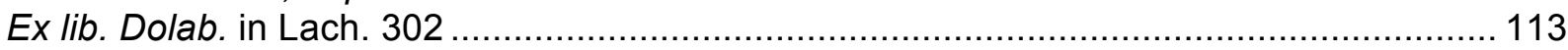

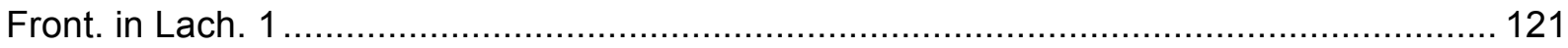

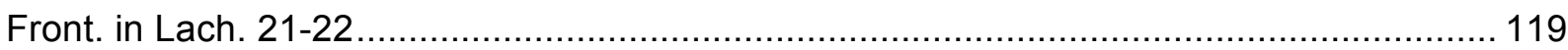

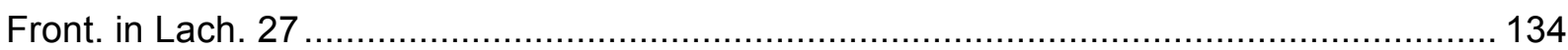

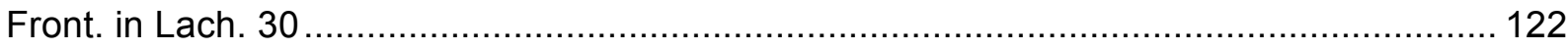

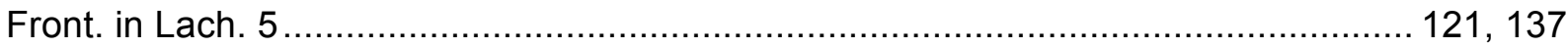

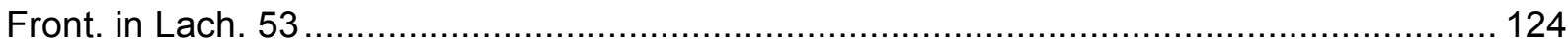

Front. in Lach. 8 ................................................................................. 124, 125, 127

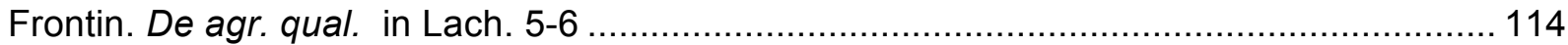

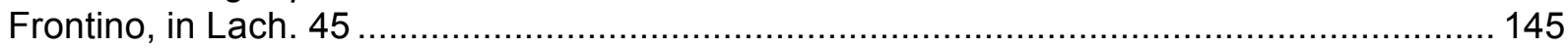

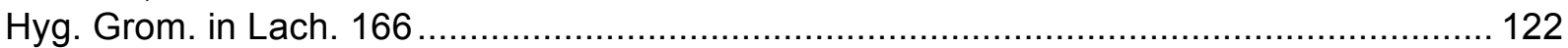

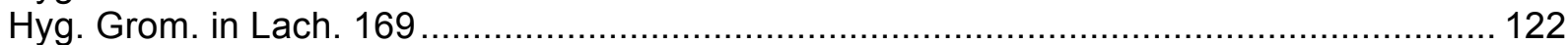

Hyg. Grom. in Lach. 170 ..................................................................... 120, 123, 126

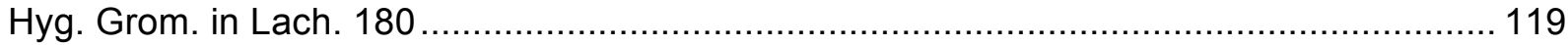

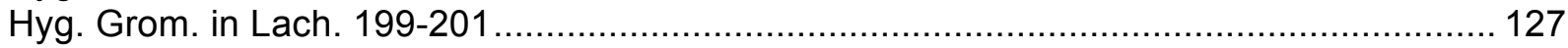

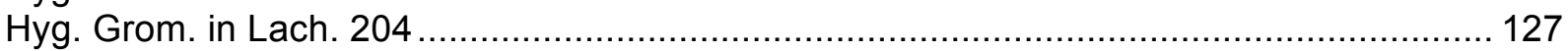

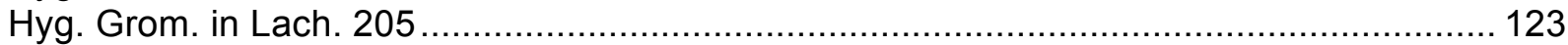

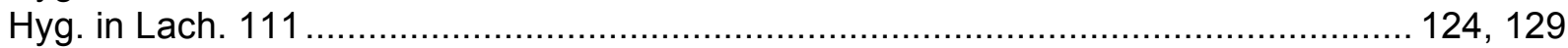

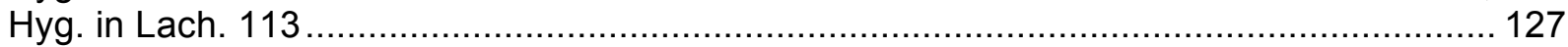

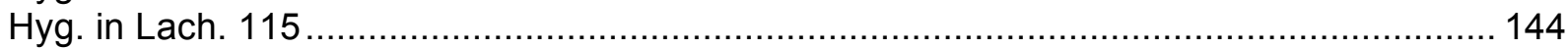

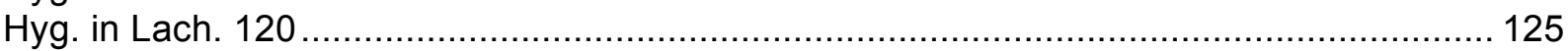

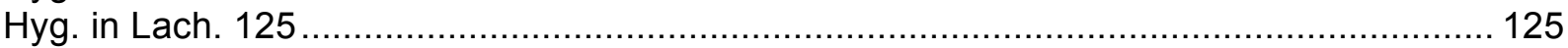

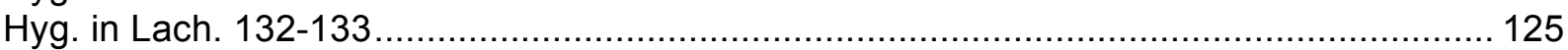

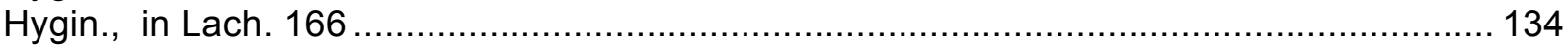

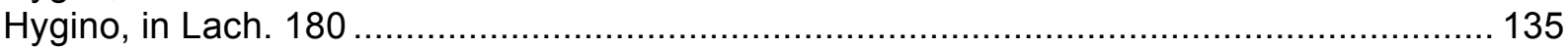

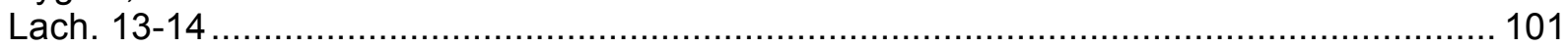

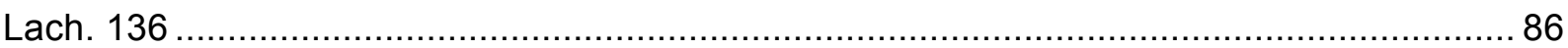

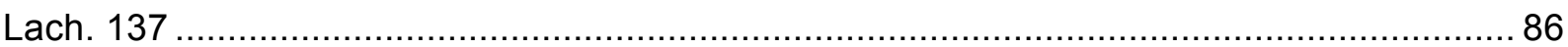

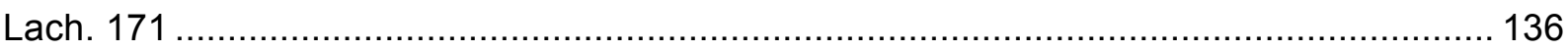

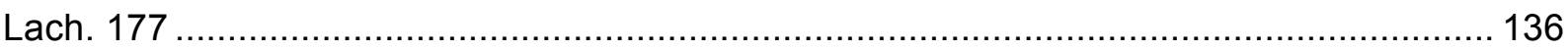

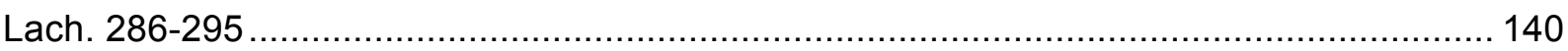

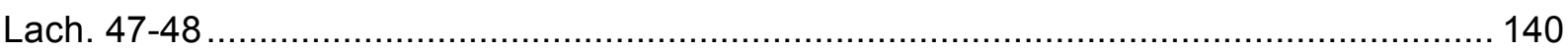

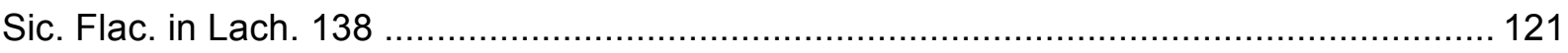

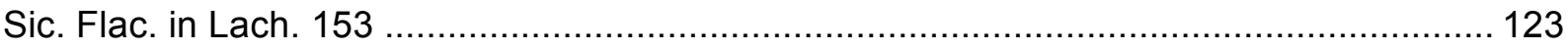

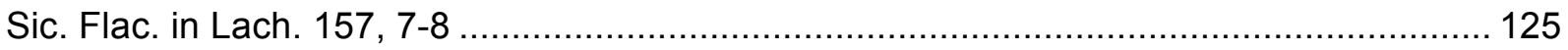

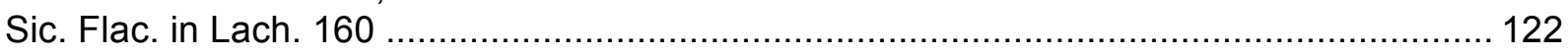

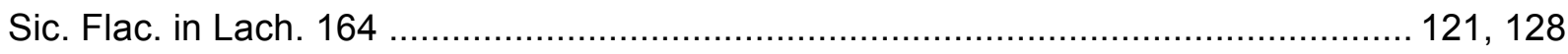

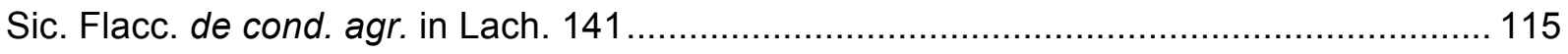

CÓDIGO CIVIL BRASILEIRO

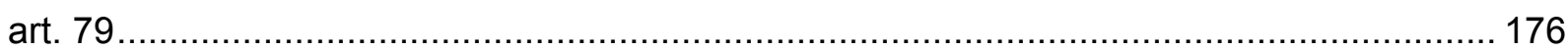




\section{Bibliografia}

AdAMIETZ, Joachim, Marcus Tullius Ciceros Pro Murena, Darmstadt, Wissenschaftlische Buchgesellschaft, 1989.

AIGNER-FORESTI, Luciana, Zeugnisse etruskischer Kultur im nordwesten Italiens und in südfrankreich - Zur Geschichte der Ausbreitung etruskischer Einfüsse und der etruskisch-griechischen Auseinandersetzung, Wien, Öst. Akademie der Wissenschaften, 1988.

AlbaneSE, Bernardo, Sacer esto, in BIDR 30 (1988), pp. 145-179.

, Usus auctoritas fundi in XII Tab. 6, 3 secondo le testimonianze di Cicerone, in Annali del Seminario Giuridico della Università di Palermo XLV.1 (=AUPA), 1998.

AlCIATUS, Andrea, De verborum significatione libri quatuor, Lugduni, S. Gryphius, 1530.

ALFöLDI, Andreas, Early Rome and the Latins, Michigan, Michigan University, s/d. , Römische Frühgeschichte - Kritik und Forschung seit 1964, Heidelberg, C. Winter, 1976.

---------, Zur Struktur des Römerstaates im 5. Jahrhundert v. Chr., in O. REVERDIN (publ.), Entretiens sur l'antiquité classique XIII - Les origines de la République romaine, Genève, Vandoevres, 1966.

Ammerman, Albert J., The Comitium in Rome from the Beginning, in American Journal of Archeology 100'1 (1996), pp. 121-136.

Ampolo, Carmine, Die endgültige Stadtwerdung Roms im 7. und 6. Jh. v. Chr. Wann entstand die civitas?, in PAPENFUSS, Dietrich; STROCKA, Volker M., (org.), Palast und Hütte - Beiträge zum Bauen und Wohnen im Altertum von Archäologen, Vor- und Frühgeschichtlern, Mainz am Rhein, P. von Zabern, 1982, pp. 319-324.

Antonsen-Resch, Andrea, Von Gnathon zu Saturio - Die Parasitenfigur und das Verhältnis der römischen Komödie zur griechischen, Berlin, W. de Gruyter, 2004.

Arangio-Ruiz, Vincenzo, Istituzioni di diritto romano, 14.a ed., Napoli, Jovene, 1960. , La compravendita in diritto romano II, Napoli, Jovene, 1954.

ARCHI, Gian Gualberto, Il concetto della proprietà nei diritti del mondo antico, in RIDA 6 (1959), pp. 229-249.

ARnott, W. Geoffrey, Alexis, Greek New Comedy and Plautus' Poenulus, in BAIER, Thomas (org.), Studien zu Plautus' Poenulus, Tübingen, G. Narr, 2004.

BarbINo, Giuseppina, L'auctoritas di Plauto in Nonio Marcello, in TAlFAcos, loannis (ed.), The Origins of European Scholarship, Stuttgart, Franz Steiner, 2005. 
BAUDY, Dorothea, Römische Umgangsriten - Eine ethologische Untersuchung der Funktion von Wiederholung für religiöses Verhalten, Berlin-New York, W. de Gruyter, 1998.

Bauer, Brigitte L. M., Word Order, in Baldi, Philip; Cuzzolin, Pierluigi (ed.), New Perspectives on Historical Latin Syntax 1 - Syntax of the Sentence, Berlin/New York, de Gruyter, 2009.

BAyeRISCHE AKADEMIE DER WISSEnschafTen, Thesaurus Lingua Latinae - editus auctoritate et concilio academiarum quinque germanicarum berolinensis gottingensis Lipiensis Monacensis Vindobonensis, vol. II, Lipsiae, B. G. Teubneri, 1900-1906.

BEAUDOUIN, Edouard, La limitation des fonds de terre dans ses rapports avec le droit de proprieté, in NRH 17 (1893), pp. 397-469.

BECKER, Wilhelm Adolf, Handbuch der römischen Alterthümer - nach dem Quellen bearbeitet 1, Leipzig, Weidmann, 1851.

BEHRENDS, Okko, Bodenheit und privates Bodeneigentum im Grenzwesen Roms, in BeHRENDS, Okko; CAPOgROSSI COlogNESI, Luigi (org.), Die römische Feldmeßkunst - Interdisziplinäre Beiträge zu ihrer Bedeutung für die Zivilisationsgeschichte Roms, Göttingen, Vandenhoeck \& Ruprecht, 1992.

, Das nexum im Mancipationsrecht oder die Ungeschichtlichkeit des Liberaldarlehens, in RIDA 21 (1973), pp. 137-184. gestigen Grundlagen des klassischen römischen Rechts mit einem vergleichenden Blick auf die Gewohnheitsrechtslehre der Historischen Rechtsschule und der Gegenwart, in WILLOWEIT, Dietmar (org.), Die Begründung des Rechts als historisches Problem, München, R. Oldenbourg, 2000.

, La mancipatio nelle XII tavole, in lura 33 (1982), pp. 46-103. jurisprudence classique, leurs points de contact et leur indépendence fondamentale: l'exemple de l'oeuvre de Frontin; structure, méthode, vocabulaire, in Conso, Danièle; GonZales, Antonio; Guillaumin, Jean-Yves (eds.), Les vocabulaires techniques des arpenteurs romains, Franche-Comté, 2005, pp. 201217.

BEKKER, Ernst Immanuel, Die römischen Komiker als Rechtszeugen, in SZ 13 (1892), pp. 53-118.

Geschichtliche Überschau, von der Zeit der Manusinjektion bis in die Gegenwart, in SZ 23 (1902), pp. 1-30.

Beloch, Julius, Campanien, Breslau, 1890.

BenedetTo, Maria Ada, Ricerche sugli ordinamenti dei domini del Delfinato nell'alta Valle di Susa, Torino, Giappichelli, 1953. 
BenvenISTE, Émile, Le vocabulaire des institutions indo-européenes II - Pouvoir, droit, religion, Paris, Minuit, 1969.

BESELER, Gerhard, Symbolaion, in SZ 50 (1930), p. 441.

BIONDI, Biondo, Leges populi romani, in Scritti giuridici 2, Milano, Giuffrè, 1965.

Bonfante, Pietro, Corso di diritto romano I, Roma, Attilio Sampaolesi, 1928. 1926.

-, Corso di diritto romano II - La proprietà 1, Roma, A. Sampaolesi,

Corso di diritto romano VI - Le successioni, parte generale, Milano, Giuffrè, 1974.

Borgeaud, Willy Alfred, Fasti Vmbrici - Études sur le vocabulaire et le rituel des Tables eugubines, Ottawa, Universitè d'Ottawa, 1982.

BozzA, Francesca, Il possesso I, Napoli, Jovene, 1935.

BREZZo, Camillo, La mancipatio, Roma, L'Erma di Bretschneider, 1972.

BRUGI, Biagio, Le dottrine giuridiche degli Agrimensori Agrimensori Romani comparate a quelle del Digesto (1897), reimpress., Roma, L'Erma di Bretschneider, 1968.

BRUGMANN, Karl, Kurze vergleichende Grammatik der indogermanischen Sprachen, Berlin, de Gruyter, 1969.

Buck, Carl Darling, A Grammar of Oscan and Umbrian: with a Colection of Inscriptions and a Glossary, Boston, Ginn \& Comp., 1904.

Carl Winter, 1905.

BuckLAND, William Warwick, A Text-Book of Roman Law: From Augustus to Justinian, Cambridge, 2007. Weimar, 1939, pp. 16-26.

BUCKLER, William Hepburn, The Origin and History of Contract in Roman Law down to the End of the Republican Period, London, C. J. Clay \& Sons, 1895.

BUDE, Guillaume, Annotationes in quatuor \& vinginti Pandectarum libros, ad loannem Deganaium Cancellarium Franciae, Paris, R. Stephanus, 1535.

BUJUKLIĆ, Zika, Leges regiae: pro et contra, in RIDA 45 (1998), pp. 89-142.

BUONAMICI, Francesco, Actio auctoritatis dell'antico diritto romano, in Archivio Giuridico Filippo Serafini 29 (1882), p. 73 e ss.

BURDESE, Alberto, resenha de G. FALCONE, Richerche sull'origine dell'interdetto uti possidetis, in SDHI 62 (1996), p. 589.

BüRge, Alfons, Die Juristenkomik in Ciceros Rede Pro Murena - Übersezung und Kommentar, Zürich, Juris Druck, 1974. 
CAMPANILE, Enrico; LeTtA, Cesare, Studi sulle magistrature indigene e municipali in area italica, Pisa, Giardini, 1979.

CAPOGRASSI, Giuseppe, Agricoltura, diritto, proprietà, in Rivista di diritto agrario 1 (1952), pp. 246-279.

CAPOGRossi Colognesi, Luigi, 'Ager publicus' e 'ager gentilicus' nella riflessione storiografica moderna, in Proprietà e signoria in Roma antica I, 2. ${ }^{a}$ ed., Roma, La Sapienza, 1994.

, La terra in Roma antica - Forme di proprietà e rapporti produttivi I, Roma, La Sapienza, 1981.

communautés rurales 2, 2, Paris, Dessain et Tolra, 1983, pp. 411-430.

-----------, Luigi, Le comunità rurali di Roma arcaica nella storiografia del tardo '800, in Studi in Memoria di Giuliana D’Amelio I, Milano, Giuffrè, 1978, pp. 174-179.

, Le servitù de passaggio e l'organizzazione del territorio romano in età republicana, in Misurare la terra: centuriazione e coloni nel mondo romano, Modena, Panini, 1985.

Laterza, 2000.

, Max Weber e le economie del mondo antico, Roma,

CARAndini, Andrea, La nascita di Roma - Dèi, Lari, eroi e uomini all'alba di uma civiltà, Torino, G. Einaudi, 1997.

CARETTONI, Gianfilippo, Excavations and Discoveries in the Forum Romanum and on the Palatine during the Last Fifty Years, in JRSt. 50 (1960), pp. 192-203

CAsInOs MORA, Francisco Javier, Auctoritas rerum decenviralis, in RIDA 50 (2003), pp. 47-96.

la noción romana de auctoritas y la responsabilidad por auctoritas, Granada, Comares, 2000.

CASSIRER, Ernst, Philosophie der symbolischen Formen II, Darmstadt, 1953.

CASTAGNoli, Ferdinando, Le richerche sui resti della centuriazione, Roma, Storia e Letteratura, 1958.

Catalano, Pierangelo, Aspetti spaziali del sistema giuridico-religioso romano, in Aufstieg und Niedergang der römischen Welt II - 16.1, Berlin-New York, W. de Gruyter, 1978.

Giappichelli, 1960.

Contributi allo studio del diritto augurale, Torino, G.

, Populus Romanus Quirites, Torino, G. Giappichelli, 1974.

Cataldo Janelli, A., Veterum oscurum inscriptiones, et tabullae eugubinae, latina interpretatione tentatae - tum specimina etymologica, Neapoli, ex Regia, 1841. 
Chesterton, Gilbert Keith, Varied Types, New York, Dodd, Mead and Company, 1908.

ClaRK, Edwin Charles, Early Roman Law: the Regal Period, London-Cambridge, Macmillan and Co., 1872.

CollaRT, Jean, A propos du mot auctoritas, in Helikon 1 (1961), pp. 211-216.

-----------, Varron: grammariere latin, Paris, Belles-Lettres, 1954.

ColbI, Ugo, Il diritto pubblico degli umbri e le tavole eugubine, Milano, Giuffrè, 1958,.

COLLINET, Paul, Les variations de l'usucapion 'pro herede' avant Hadrien, in Studi in onore di Salvatore Riccobono IV, Palermo, 1936.

Cornell, T. J., Rome and Latium Vetus, 1974-1979, in Archaeological Reports 26 (1979-1980), pp. 71-89.

--------, Rome and Latium Vetus, 1980-1985, in Archaeological Reports 32 (1985-1986), pp. 123-133.

CORREAA, Alexandre; SCIASCIA, Getano, Manual de Direito Romano, 6. ${ }^{a}$ ed., São Paulo, RT, 1988.

CORSSEN, Wilhelm Paul, Ueber steigerungs- und vergleichungsendungen im lateinischen und in den italischen dialekten, in Zeitschrift für vergleichende Sprachforschung auf dem Gebiete des deutschen, griechischen und lateinischen 3 (1854), pp. 272-305.

Costa, Emilio, Cicerone Giurisconsulto I, Bologna, N. Zanichelli, 1927.

Roma,1968.

Courtney, Edward, Archaic Latin Prose, London, Oxford University, 2000.

CUJAS, Jaccques, Paratitla in libris VIII Codicis Justiniani, lib. VIII, tit. XLIV, que citamos de Jacobi Cujacii Opera, ad parisiensem fabrotianam editionem, t. 8, Prati, Fratr. Giachetti, 1839.

CuQ, Edouard, Études sur le droit babylonien - les lois assyriennes et les lois hittites, Paris, P. Geuthner, 1929.

, Le droit élamite d'après les actes juridiques de Susa, in Revue d'assirologie et d'archeologie orientale 29 (1932), pp. 149-182.

-, Les institutions juridiques des romains 1, 2. ${ }^{\text {a }}$ ed., Paris, Plon, 1904.

D'IPPolito, Federico, Questioni decemvirali, Napoli, Ed. Scientifiche Italiane, 1993.

D'Ors, Alvaro, Elementos de derecho privado romano, Pamplona, Navarra, 1960.

DAUBE, David, Furtum proprium and furtum improprium, in Cambridge Law Journal 6 (1936-1938), pp. 217-234.

De Franciscl, Pietro, Arcana Imperii III, t. 1, Milano, Giuffrè, 1948. 
--------------, II trasferimento della proprietà - Storia e critica di uma dottrina, Padova, Universitaria, 1924. , Primordia civitatis, Romae, Apollinaris, 1959.

De Martino, Francesco, Storia della costituzione romana I, $2 .^{a}$ ed., Napoli, Jovene, 1972.

DE VISSCHER, Fernand, La jurisprudence romaine et la notion de l'«auctoritas», in Recueil d'études sur les sources du droit en honneur de F. Geny, t. 1, Liechtenstein, Topos, 1977, pp. 32-41.

pp. 603-645.

-, Le rôle de l'auctoritas dans la mancipatio, in RH 12 (1933), , Mancipium et res mancipi, in SDHI 2, pp. 263-324.

Devoto, G., Tabulae Iguvinae, Roma, Regia Officina, 1937.

DI MARZO, Salvatore, Istituzioni di diritto romano, Milano, Giuffrè, 1945.

DILKE, Oswald Ashton Wentworth, The Roman Land Surveyors - An Introduction to the Agrimensores, Newton Abbot, David \& Charles, 1971.

DINDORF, Wilhelm, Harpocrationis lexicon in decem oratores atticos II - Annotationes interpretum, Oxford, 1853.

DıósDI, György, Ownership in Ancient and Preclassical Roman Law, Budapest, Akadémiai Kaidó, 1970.

DIRKSEN, Heinrich Eduard, Uebersicht der bisherigen Versuche zur Kritik und Herstellung des Textes der Zwölf-Tafel-Fragmente, Leipzig, Hinrichs, 1824.

DomASZEWSKI, Alfred von, Abhandlungen zur römischen Religion, Leipzig-Berlin, Teubner, 1909.

DUMÉZIL, Georges, Archaic Roman Religion I, Chicago-London, University of Chicago, 1970.

, Augur, in Revue des Études Latines 35 (1957), pp. 126-151.

Gallimard, 1977.

Dyck, Andrew R., A Commentary on Cicero, De Legibus, Michigan, University of Michigan, 2004.

ERNST, W., Rechtsmängelhaftung, Tübingen, Mohr, 1995.

ERREN, Manfred, P. Vergilius Maro, Georgica II - Kommentar, Heidelberg, Universität, 2003.

Estienne, Robert, Dictionarium, seu latinae linguae thesaurus v. 1, Lutetia, R. Stephanus, 1531.

FEENSTRA, Robert, Romeinsrechtelijke grondslagen van het Nederlands privaatrecht: inleidende hoofdstukken, Amsterdan, Brill, 1990. 
FERRINI, Contardo, Storia delle fonti del diritto romano e della giurisprudenza romana, Milano, U. Hoepli, 1885.

FIORI, Roberto, Homo sacer - Dinamica politico-costituzionale di una sanzione giuridico-religiosa, Napoli, Jovene, 1996.

FLACH, Dieter, Römische Agrargeschichte, München, Beck, 1990.

FRAENKEL, Eduard, Plautinisches im Plautus, 2. a ed., Hildesheim, Weidmann, 2000.

FRAENKEL, Hermann, Dichtung und Philosophie des frühen Griechentums - Eine Geschichte der grieschichen Epik, Lyrik und Prosa bis zur Mitte des fünften Jahrhunderts, München, Beck, 1962.

FrancIOSI, Gennaro, 'Gentiles familiam habento', in FrancIOSI, Gennaro (org.), Richerche sulla organizatione gentilizia romana, Napoli, Jovene, 1995.

, La limitatio nell'ager campanus, in FRANCIOSI, Gennaro (org.), La romanizzazione della campania antica I, Napoli, Jovene, 2002.

, Per la storia dell'usucapione immobiliare in Roma antica, in SDHI 69 (2003), pp. 127-147.

FRANK, Tenney, Agriculture in early Latium, in The American Economic Review $9^{2}$ (1919), pp. 267-268.

Frank, Tenney, An Economic History of Rome, 2. ${ }^{\text {a }}$ ed., New York, Cosimo, 2005.

Some Economic Aspects of Rome's Early Law, in Proceedings of the American Philosophical Society 70² (1931), pp. 193-205.

Fredershausen, Otto, Weitere Studien über das Recht bei Plautus und Terenz, in Hermes 47 (1912), pp. 199-249.

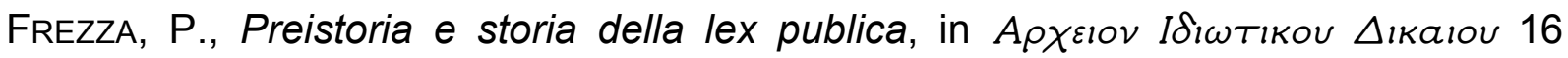
(1953), pp. 54-76.

FUENTESECA, Pablo, Trasferimento della proprietà e «auctoritas» nella vendita romana, in VACCA, Letizia (org.), Vendita e trasferimento della proprietà nella prospettiva storico-comparatistica - Atti del Congresso Internazionale PisaViareggio-Lucca, 17-21 aprile, 1990, t. 1, Milano, Giuffrè, 1991.

GABBA, Emilio, Per la tradizione dell'heredium romuleo, in Roma arcaica - Storia e storiografia, Roma, Edizioni di Storia e Letteratura, 2000.

Athenaeum 73 (1985), pp. 265-284.

Gagarin, Michel, Early Greek Law, in Gagarin, Michel, Cohen, David (eds.), The Cambridge Companion to Ancient Greek Law, Cambridge, Cambridge University, 2005.

GALLo, Filippo, Studi sulla distinzione fra res mancipi e res nec mancipi, Torino, G. Giappichelli, 1958. 
Gargola, Daniel J., Lands, Laws, \& Gods - Magistrates \& Ceremony in the Regulation of Public Lands in Republican Rome, Chapel Hill-London, University of North Carolina, 1995.

GIFFARD, André Edmond, Le sens du môt "auctoritas» dans les lois relatives à l'usucapion, in $R H 17,1938$, pp. 339-364.

GIOFFREDI, Carlo, Religione e diritto nella più antica esperienza romana - per la definizione del concetto di «ius», in SDHI 20 (1954), pp. 245-290.

GIRARD, Paul Frédéric, L'edit perpetuel, in NRH 28 (1904), pp. 117-164.

, L'histoire des XII tables, in NRH 26 (1902), pp. 381-436.

, La garantie d'éviction dans la vente consensuelle, in NRH 8 (1884), pp. 395-439.

, Les stipulations de garantie, in NRH 7 (1883), pp. 537-602.

GIRARD, Paul-Frédéric, L'action auctoritatis, in NRH 6 (1882), pp. 180-205.

GIRARD, Paul Fréderic; MAYR, Robert, Geschichte und System des römischen Rechtes 1, Berlin, F. Vahlen, 1908.

GIRAUD, Charles, Recherches sur le droit de propriété chez le romains - sous la République et sous l'Impire, t. 1, Aix, Aubin, 1838.

GJERSTAD, Einar, Early Rome IV - Historical Survey, Lund, Berlingska, 1973.

GlebA, Margarita, Archaeology in Etruria - 1995-2002, in Archaeological Reports 49 (2002), pp. 89-103.

GondA, Jan, Ancient-indian ojas, Latin augos and the Indo-European nouns in -es-/os, Utrecht, A. Oosthoek, 1952,6.

Gorgola, Daniel J., The Ritual of Centuriation, in KonRAD, Christoph F. (ed.), Augusto augurio - Rerum humanarum et divinarum commentationes in honorem Jerzy Linderski, Stuttgarg, F. Steiner, 2004, p. 123).

GREEN, William M., Greek and Roman Law in the Trinummus of Plautus, in Classical Philology 242 (1929), p. 183-192.

GReEnIDGe, A. H. J., The Authenticity of the Twelve Tables, in The English Historical Review vol. 20, n. ${ }^{\circ} 77$ (1905), p. 21.

GROSCH, Georg, Markgenossenschaft und Grossgrundherrschaft im früheren Mittelalter - Eine staats- und rechtsgeschichtliche Untersuchung (reimpress. da ed. de 1911), Lübeck, Matthies, 1965.

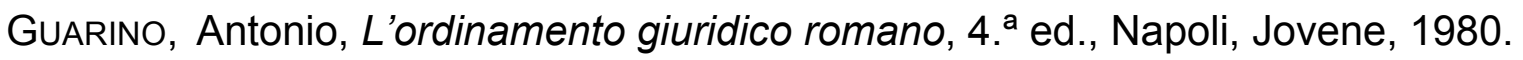
, Giusromanistica elementare, Napoli, Jovene, 1989.

1973. 
GuIRAUD, Paul, La propriété primitive à Rome, in Revue des études anciennes 4 (1909), pp. 221-255.

Hammond, Mason, Germana patria, in Harvard Studies in Classical Philology 60 (1951), pp. 147-174.

HARDY, Ernest George, Roman laws and charters, Oxford, Clarendon, 1912.

HEDENIUS, Ingemar, Om rätt och moral, Stockholm, Tidens, 1941.

HEINECKE, Johannes Gottlieb, Antiquitatum romanorum jurisprudentiam illustrantium syntagma, Francofurt ad Moenum, H. L. Broenneri, 1841.

HeINZE, Richard, Auctoritas, in Hermes 60 (1925), pp. 348-366.

HILPRECHT, Hermann Volrath, The Babylonian Expedition of the University of Pennsylvania - Series A: Cuneiform Texts, Philadelphia, University of Pennsylvania, 1909.

HINRICHS, Focke Tanen, Die Geschichte der gromatischen Institutionen Untersuchungen zu Landverteilung, Landvermessung, Bodenverwaltung und Bodenrecht im römischen Reich, Wiesbaden, F. Steiner, 1974.

Holland, Louise Adams, Qui Terminus Exarasset, in American Journal of Archeology $37^{4}$ (1933), pp. 549-553.

HONSELL, Heinrich, Der Gesetzesstil in der römischen Antike, in Scritti in onore di Antonio Guarino (=Sodalitas) 4, pp. 1659-1673.

HöRLE, Josef, Catos Hausbücher - Analyse seiner Schrift De Agricultura nebst Wiederherstellung seines Kelterhauses und Guthofes, Paderborn, F. Schöningh, 1929.

HUSCHKE, Phillip Eduard, Über das Recht des nexum und das alte römische Schuldrecht - eine rechtshistorische Untersuchung, Leipzig, Gebauer, 1846.

JANSEN, Henrdrik Hubertus, Historische grammatica van het Latijn, Utrecht, Spectrum, 1992.

JHERING, Rudolf von, Geist des römischen Rechts auf den verschiedenen Stufen seiner Entwicklung I, 8. ${ }^{a}$ ed., Leipzig, Breitkopf \& Härtel, 1924.

Johnson, David, Roman Law in Context, Cambridge, 1999.

JöRS, Paul; KUnKel, Wolfgang; Wenger, Leopold; Honsell, Heinrich; MAYer-Maly, Theo; SelB, Walter, Römisches Recht, 4. ${ }^{a}$ ed., Berlin-Heidelberg, Springer, 1987.

KAïLA, El, L'unité foncière en droit romain, Paris, B. de Boccard, 1927.

KaRLOWA, Otto, Römische Rechtsgeschichte 2, Leipzig, Veit \& Comp., 1901.

KASER, Max, Altrömisches Eigentum und usucapio, in SZ 105 (1988), pp. 122-164.

-----------, Das altrömische lus - Studien zur Rechtsvorstellung und Rechtsgeschichte der Römer, Göttingen, Vandenhoek \& Ruprecht, 1949. 
---------, Das römische Privatrecht I - Das altrömische, das vorklassische und klassische Recht, 2.a ed., München, Beck, 1971.

-------------, Eigentum und Besitz im älteren römischen Recht, Weimar, H. Böhlaus, 1943.

------, In bonis esse, in SZ 78 (1961), pp. 173-220.

-----------, Mores maiorum und Gewohnheitsrecht, in SZ 59 (1939), pp. 52-101.

--------, Natürliche Eigentumserwerbsarten im altrömischen Recht, in SZ 65 (1947), pp. 239 e ss.

190.

-, Neue Studien zum altrömischen Eigentum, in SZ 68 (1951), pp. 131-, Rechtswidrigkeit und Sittenwidrigkeit im klassichen römischen Recht, in SZ 60 (1940), pp. 95-150.

----------, Über 'relatives Eigentum' im altrömischen Recht, in SZ 102 (1985), pp. 1-39. , Zur 'legis sacramento in rem', in SZ 104, (1987), pp. 57.

-,Typen des römischen Bodenrechts in der späteren Republik, in SZ 62 (1942), pp. 1-81.

KAUFMANN, Horst, Die altrömische Miete - Ihre Zusammenhänge mit Gesellschaft, Wirtschaft und staatlicher Vermögensverwaltung, Köln-Graz, Böhlau, 1964.

KAYSER, C. L., M. Tulli Ciceronis - Opera rethorica ex optimis libris manuscriptis, vol. 1, Lipsiae, B. Tauchnitz, 1860.

KeIL, Heinrich; Hagen, Hermannus, Grammatici latini, Hildesheim, G. Olms, 1961.

KIDSON, Peter, A metrological Investigation, in Journal of the Warburg and Courtauld Institutes 53 (1990), pp. 71-97.

KIPP, Theodor, Geschichte der Quellen des römischen Rechts, 4. ed., Leipzig, A. Deichert, 1919.

KoROSEC, Viktor, Keilschriftrecht, Leiden, E. J. Brill, 1964.

KoschaKeR, Paul, Eheformen bei den Indogermanen, Berlin, W. de Gruyter, 1937.

-------------, Forschungen und Ergebnisse in den keilschriftlichen Rechtsquellen, in SZ 49 (1929), pp. 188-189.

, Göttliches und weltliches Recht nach den Urkunden aus Susa, in Orientalia 4 (1935), pp. 38-80.

----, Keilschriftrecht, in Zeitschrift der Deutschen Morgenländischen Gesellschaft 89 (1935), pp. 1-39.

KRETSCHMER, Paul, Das Nexum und sein Verhältnis zum Mancipium, in SZ 29 (1908), pp. 227-280. 
(1924), pp. 101-114

und die Abstrakta im Indogermanischen, in Glotta 13 Lat. quirites und quiritare, in Glotta 10 (1920), p. 148.

LABRUNA, Luigi, Quirites, in Labeo 8 (1962), p. 345.

LACHMANN, Carl, Die Schriften der römischen Feldmesser I, Berlin, G. Reimer, 1848.

LAMBERT, Edouard, La question de l'authenticité des XII tables et les 'Annales maximi', in NRH 26 (1902), pp. 143-200.

LAMBERT, Jacques N., Les origines de Rome à la lumière du droit comparè, in Studi De Francisci I, Milano, Giuffrè, 1956, p. 348.

LANGE, Ludwig, Römische Alterthümer 1, Berlin, Weidmann, 1856.

-, Römische Alterthümer 2, Berlin, Weidmann, 1862.

LATTE, Kurt, Religiöse Begriffe im frührömischen Recht, in SZ 67 (1950), pp. 47-61. , Römische Religionsgeschichte, München, Beck, 1960.

LAUTNER, Julius G., Zur Bedeutung des römischen Rechts für die europäische Rechtskultur und zu seiner Stellung im Rechtsunterricht, Zürich, Juris, 1976.

LEIFER, Franz, Mancipium und auctoritas, in SZ 66 (1936), pp. 136-235.

------------, Zum Problem der Foruminschrift unter dem Lapis Niger. Zwei neue Lösungsvorschläge, Aalen, Scientia, 1963.

LEIST, Burkard Wilhelm, Alt-arisches Jus Civile II, Jena, G. Fischer, 1896.

LEITNER, Phillip, Die plautinischen Komödien als Quellen des römischen Rechts, in CANTARElla, Eva; Gagliard, Lorenzo (org.), Diritto e teatro in Grecia e a Roma, Milano, Giuffrè, 2007, pp. 69-93.

Lenel, Otto, Das Edictum Perpetuum - ein Versuch zu seiner Widerherstellung (1907), 2. ${ }^{a}$ reimpr. da 3. ${ }^{\circ}$ ed., Aalen, Scientia Verlag, 1974.

---, Das Nexum, in SZ 23 (1902), pp. 84-101.

177-197.

LEONHARD, Rudolf, Institutionen des römischen Rechts - ein Lehrbuch, Leipzig, 1894.

LeVY, Mario Attilio, L'auctoritas d'Augusto, in RIDA 39 (1992), pp. 185-201.

LÉVY-BruHL, Henri, Praedia absentia solent mancipari, in Studi Paoli (s/d), pp. 477484.

LEWIS, George Cornewall, Untersuchungen über die Glaubwürdigkeit der altrömische Geschichte I, 2. ed., Hannover, C. Rümpler, 1863.

LEWIS, Hubert, The Ancient Laws of Wales - Viewed Especially in Regard to the Light they Throw upon the Origin of Some English Institutions, London, s/e, 1889. 
LIDDELL, Henry George; SCOTT, Robert; JONES, Henry Stuart; McKenZIE, Roderick, Greek-English Lexicon, London, Oxford University, 1996.

LINDSAY, Wallace Martin, The Latin Language: An Historical Account of Latin Sounds, Stems and Flexions, Oxford, Clarendon, 1894.

LLOYD, John Edward, A History of Wales from the Earliest Times to the Edwardian Conquest I (1911), reimpress., Charleston, BiblioLife, 2009.

LoNG, G., Miscelaneous, I. On the site of Susa, in Journal of the Royal Geographical Society of London 3 (1833), pp. 257-267.

LÜвтоW, Ulrich von, Das römische Volk - Sein Staat und sein Recht, Frankfurt, V. Klostermann, 1955.

Die Bedeutung des römischen Rechts für unsere Rechtskultur, Rheinfelden-Freiburg-Berlin, Schäuble, 1989.

, Die Entwicklungsgeschichtlichen Grundlagen des römischen Erbrechts, in Studi in onore di Pietro De Francisci I, 1956.

, Zum Nexumproblem, in SZ 67 (1950), pp. 112-161.

LuzzATto, Giuseppe Ignazio, Le organizzazioni preciviche e lo stato, Modena, Premiata, 1948.

MAgdelain, André, Auctoritas rerum, in RIDA 5 (=Mélanges F. de Visscher IV) (1950), pp. 127-153.

$25-45$.

, De l'auctoritas patrum à l'auctoritas senatus, in lura 33, 1982, pp. De la royauté et du droit de Romulus a Sabinus, Rome, L'Erma di Bretschneider, 1995.

161.

MAKINSON, David, Deontic Logic in Computer Science, Workshop $\triangle E O N ' 08$, Bolonha, 8 a 10 de janeiro de 2008, publicado em MAKINSON, David, On a Fundamental Problem of Deontic Logic, in P. McNamara, H. Prakken (eds.), Norms, Logics and Information Systems - New Studies on Deontic Logic and Computer Science, Amsterdam, IOS, 1999, pp. 29-54.

Mantovani, Dario, L'occupazione dell'ager publicus e le sue regole prima del 367 a.C, in Athenaeum 85 (1997), p. 575-598.

MAnzo, Annamaria, La lex Licinia Sextia de modo agrorum - Lotte e leggi agrarie tra il V e il IV secolo a.C, Napoli, Jovene, 2001.

MARQUARDT, Joachim, Römische Staatsverwaltung, 2 vols., 3. ${ }^{a}$ ed., Darmstadt, H. Gentner, 1957.

MAY, Gaston, Éléments de droit romain, 18. ${ }^{a}$ ed., Paris, R. Sirey, 1932. 
MAYER-Maly, Theo, Studien zur Elementarliteratur über die usucapio, in Studi in onore di Emilio Betti III, Milano, Giuffrè, 1962.

-, Römisches Recht, 2. ${ }^{\text {a }}$ ed., Wien-New York, Springer, 1999.

$16-40$.

, Studien zur Frühgeschichte der usucapio I, in SZ 77 (1960), pp.

221-276.

MAZZARINo, Santo, Sociologia del mondo etrusco e problemi della tarda etruscità, in Historia 6 (1957), pp. 98-122.

McDonelL, Arthur Anthony, A practical Sanskrit dictionary, London, Oxford University, 1924.

MeIRA, Sílvio, Instituições de Direito Romano, 2. ${ }^{a}$ ed., São Paulo, Max Limonad, s/d.

MeITZEN, August, Wanderungen, Anbau und Agrarrecht der Völker Europas nördlich der Alpen - Erste Abteilung: Siedelung und Agrarwesen der Westgermanen, Ostgermanen, der Kelten, Römer, Finnen und Slawen I, Berlin, Wilhelm Hertz, 1895.

MERCER, Samuel A. B., The Oath in Cuneiform Inscriptions - The Oath in Babylonian Inscriptions of the Time of the Hammurabi Dynasty, in The American Journal of Semitic Languages and Literatures 29² (1913), pp. 65-94.

MiCHEL, Jacques-Henri, L'usucapio des immeubles durait-elle deux ans?, in Hommage à René Dekkers, Bruxelles, Bruylant, 1982.

Millett, Paul, Sale, credit and exchange in Athenian law and society, in Nomos: Essays in Athenian Law, Politics, and Society, Cambridge, Cambridge University, 1990.

MItTEIS, Ludwig, Römisches Privatrecht - bis auf die Zeit Diokletians I Grundbegriffe und Lehre von den Juristischen Personen, Leipzig, Duncker \& Humblot, 1908.

Momigliano, Arnoldo, An Interim Report on the Origins of Rome, in JRSt 53 (1963), pp. 95-121.

, Roma arcaica, Firenze, Sansoni, 1989.

, Terzo contributo, in JRSt 53 (1963), p. 95 e ss.

Mommsen, Theodor, Das italische Bodentheilung und die Alimentartafeln, in Hermes 19 (1894), pp. 393-416.

-, De auctoritate commentatio (1907), in Gesammelte Schriften III, reimpress., Zürich-Hildesheim, Weidmann, 1994.

, Die unteritalischen Dialekte, Leipzig, G. Wigand, 1850.

, Nexum, in SZ 23 (1902), pp. 348-355.

-, Römische Geschichte I, 5. ${ }^{\mathrm{a}}$ ed., Berlin, Weidmann, 1868. 
---------, Römisches Staatsrecht III.1, Leipzig, von S. Hirzel, 1887.

MONIER-WILliAmS, Monier, A Sanskrit-English dictionary, etymologically and philologically arranged, 2. ${ }^{a}$ ed., Oxford, Clarendon, 1960.

MoreiRa Alves, José Carlos, Direito Romano II, 6. ${ }^{a}$ ed., Rio de Janeiro, Forense, 1998.

MousouRAKIS, George, A Legal History of Rome, London/New York, Routledge, 2007.

NAP, Jan M., Heredium en hortus in de twaalf tafelen, in TR 1 (1918-1919), pp. 390399.

NesselRath, Heinz-Günther, Die attische mittlere Komödie - ihre Stellung in der antiken Literaturkritik und Literaturgeschichte, Berlin, W. de Gruyter, 1990.

NiebuhR, Barthold Georg, Römische Geschichte I, Berlin, G. Reimer, 1853.

NoAilles, Pierre, L'auctoritas dans la loi des douze tables, in Fas et Jus - études de droit romain, Paris, Belles Lettres, 1948, pp. 223-276.

NoAilLes, Pierre, Nexum, in RH 19-20 (1940/41), pp. 205-274.

NöRR, Dieter, Die Entstehung der longi temporis praescriptio - Studien zum Enfluß der Zeit im Recht und zur Rechtspolitik in der Kaiserzeit, Köln-Opladen, Westdeutscher, 1969.

NOYES, C. Reinold, The Institution of Property - A Study of the Development, Substance and Arrangement of the System of Property in Modern AngloAmerican Law, Clark, The Lawbook Exchange, 2007.

OLgIVIE, Robert Maxwell, Early Rome and the Etruscans, Glasgow, Fontana/Collins, 1976.

ORESTANO, Ricardo, I fatti di normazione nell'esperienza romana arcaica, Torino, G. Giappichelli, 1967.

Dal ius al fas, in BIDR 46 (1939), pp. 194-273.

PAIS, Ettore, Storia di Roma I, Torino, Carlo Clausen, 1898.

Pallotino, Massimo, Le origini di Roma, in Archeologia Classica 12 (1963), pp. 1-36.

PALMER, Robert, The Archaic Community of the Romans, Cambridge, Cambridge University, 1970.

PANKIENWICZ, Ryszard, Quelques remarques sur l'économie prémonetaire dans la Rome archaïque, in Acta Classica 33 (1990), pp. 65-75. epoce archaicznej, in Rodzina $w$ społeczeństwach antycznych $i$ wczesnym chrześcijaństwie. Literatura, prawo, epigrafika, sztuka, Bydgoszcz, Wyższa Szkoła Pedagogiczna w Bydgoszczy, 1995.

PAULI, Ugo Enrico, Comici latini e diritto attico, Milano, Giuffrè, 1962. 
PERNICE, Alfred, Labeo - römisches Privatrecht im ersten Jahrhundert der Kaiserzeit 3 (1878), reimpress., Allen, Scientia, 1963.

PeruzzI, Emilio, Origini di Roma II - Le lettere, Bologna, Pàtron, 1973.

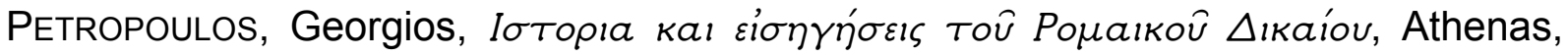
1944.

PFEIFER, Guido, Keilschriftrechte und historische Rechtsvergleichung metodengeschichtliche Bemerkungen am Beispiel der Eviktionsgarantie in Bürgschaftsform, in SCHMIDT-RECLA, Adrian; SCHUMANN, Eva; THEISEN, Frank (org.), Sachsel im Spiegel des Rechts - lus Commune Propriumque, KölnWeimar-Wien, Bohlau, 2001.

Pflüger, Heinrich Hackfeld, Nexum und mancipium, Leipzig, Duncker \& Humblot, 1908.

PhILLIMORE, John George, Private Law among the Romans, from the Pandects, London-Cambridge, Macmillan and Co., 1863.

Piccaluga, Giulia, Terminus: il segni di confine nella religione romana, Roma, Ateneo, 1974.

Poccetti, Paolo, Nuovi documenti italici, Pisa, Giardini, 1979.

Poebel, Arno, Babylonian Legal and Business Documents from the Time of the First Dinasty of Babylon chiefly from Nippur, Philadelphia, University of Pennsylvania, 1909.

PöHLmanN, Robert, Geschichte der antiken Kommunismus und Sozialismus II, München, Beck, 1901.

Pontes de Miranda, Francisco Cavalcanti, Comentários ao Código de Processo Civil II - Arts. 46-153, 2.a ed., Rio de Janeiro, Forense, 1974. obrigações: Negócios jurídicos bilaterais e negócios juridicos plurilaterais. Pressupostos. Vícios de direito. Evicção. Redibição. Espécies de negócios jurídicos bilaterais e de negócios jurídicos plurilaterais, 3. ${ }^{\mathrm{a}}$ ed., Rio de Janeiro, Borsoi, 1972. Aquisição da propriedade imobiliária, 2.a ed., Rio de Janeiro, Borsoi, 1954.

Poultney, J. W., The Bronze Tables of Iguvium, in Philosophical Monographs American Philological Association 18 (1959), pp. 1-333.

PUCHTA, Georg Friedrich, Adversus hostem aeterna auctoritas, in Kleine civilistische Schriften, Leipzig, Breitkopf und Härtel, 1851.

-, Cursus der Institutionen 1, Leipzig, Breitkopf-Härtel, 1881.

PugsLeY, David, Quod autem valet mancipatio..., in Americans are aliens - and other essays on Roman Law, Exeter, University of Exeter, 1989, pp. 32-40. 
--------------, The Roman Law of Property and Obligations, Cape Town, Juta \& Company, 1972.

RABEL, Ernst, Die Haftung des Verkäufers wegen Mangels im Rechte, Leipzig, Veit \& Comp., 1902. Comp., 1902.

RABINOWITZ, Jacob, The Susa tablets, the Bible and the Aramaic papyri, in Vetus Testamentum $11^{1}$ (1961), pp. 55-76.

Radin, Max, Greek Law in Roman Comedy, in Classical Philology 5 (1910), pp. 365367.

RASmUSSEN, Tom, Archaeology in Etruria - 1980-1985, in Archaeological Reports 32 (1985), pp. 102-122.

(1995), pp. 48-58.

Ravelli, Franco, Howarth, Paula J., Etruscan cunicoli: tunnels for the collection of pure water, in Transactions of the XII International Congress on Irrigation and Drainage, v. 2, Fort Collins, 1984.

REGOLI, E., Le prime forme de suddivisione del suolo in Italia, in (s/a) Misurare la terra: centuriazione e coloni nel mondo romano, Modena, Panini, 1985.

REIN, Wilhelm, Das Privatrecht und der Civilprocess der Römer, Leipzig, F. Fleischer, 1858.

RICHTER, Will, Gegenständliches Denken archaisches Ordnen - Untersuchungen zur Anlage von Cato de agri cultura, Heidelberg, C. Winter, 1978.

RIDGWAY, David; RIDGWAY, Francesca (ed.), Italy Before the Romans - The Iron Age, Orientalizing and Etruscan periods, London - New York - San Francisco, Academic, 1979.

RIETSTAP, Adrian Joannes Theodor, De venditore, an evictionis nomine cogatur emtorem defendere, ex jure romano, Haga, H. P. de Swart \& Fil., 1854.

RoBY, Henry John, The Twelve Tables of Gortyn, in Law Quartely Review 2 (1886), pp. 135-152.

RoselaAr, Saskia T., Public Land in the Roman Republic - A Social and Economic History of Ager Publicus in Italy, 396-89 BC, New York, Oxford University, 2010.

RosenBeRg, Arthur, Der Staat der alten Italiker - Untersuchungen über die ursprüngliche Verfassung der Latiner, Osker und Etrusker, Berlin, Weidmann, 1913.

RoussieR, Jules, lus auctoritatis, in RH 29, 1951, pp. 231-239. 
RUDORFF, Adolf, Grommatische Institutionen, in BLUME, Friedrich; LACHMANN, Carl; RUDORFF, Adolf (org.), Die Schriften der römischen Feldmesser II, Berlin, G. Reimer, 1852.

SABbATUCCI, Dario, Sacer, in Studi e Materiali di Storia delle Religioni 23 (1951/1952), p. $91-101$.

SAN-Nicolo, Mariano, Die Schlußklauseln der altbabylonischen Kauf und Tauschvertrage - ein Beitrag zur Geschichte des Barkaufes, München, Beck, 1922.

SARgentI, Manlio, Per una revisione della nozione dell'auctoritas come effetto della mancipatio, in Studi in onore di Emilio Betti IV, Milano, Giuffrè, 1962.

Sbordone, Francesco, Per la sintassi delle XII tavole, in Synteleia Vicenzo Arangio Ruiz, Napoli, Jovene, 1964, pp. 334-339.

ScHARFF, Gerhard, Die Lehre vom Gewährerlass (pactum de non praestanda evictione) nach römischen Recht, Greifswald, F. W. Kunike, 1888.

SCHEIDEL, Walter, The Demography of Roman State Formation in Italy, in M. JEHNE, Martin, PfEILSCHIFTER, Rene (eds.), Herrschaft ohne Integration? Rom und Italien in republikanischer Zeit, Frankfurt, Antike, 2006, pp. 207-226.

SCHEIL, Vicent, Actes juridiques susiens - Mémoires de la mission archéologique de Perse: Mission em Susiene, vols. XXIII-XXIV, Paris, E. Leroux, 1932-1933.

SCHERER, Anton, Handbuch der lateinischen Syntax, Heidelberg, C. Winter, 1975.

Schoemann, Georg Friedrich, De voce auctor, in Opuscula academica III, Berolini, Weidmanniana, 1858.

SchönBerger, Otto, Marcus Porcius Cato - Vom Landbau, Fragmente, Darmstadt, Wissenschaftliche Buchgesellschaft, 1980.

SCHORR, Moses, Urkunden des altbabylonischen Zivil- und Prozessrechts, Leipzig, J. C. Hinrich, 1913.

SCHRÖDER, Leopold, Bhagavadgita - Des Erhabenen Sang, Düsseldorf-Köln, Diederichs, 1952.

SCHUBERT, Charlotte, Land und Raum in der römischen Republik - Die Kunst des Teilens, Darmstadt, Wissenschaftliche Buchgesellschaft, 1996.

Schulz, Fritz, Prinzipien des römischen Rechts, München-Leipzig, Duncker \& Humblot, 1934.

SCHWARZE, Kurt, Beiträge zur Geschichte altrömischer Agrarprobleme, Halle, M. Niemeyer, 1912.

ScIALOJA, Vittorio, Teoria della proprietà nel diritto romano, Roma, A. Sampaolesi, 1928. 
ScotT, Russell T., The Contribution of Archaeology to Early Roman History, in RaAflaub, Kurt A., Social Struggles in Archaic Rome: New Perspectives on the Conflict of the Orders, Oxford, Blackwell, 2005.

Sealey, Raphael, The Justice of the Greeks, Ann Arbor, University of Michigan, 1994.

SERRAO, Feliciano, Diritto privato, economia e società nella storia di Roma I - Dalla società gentilizia alle origini dell'economia schiavistica, Napoli, Jovene, 2006. diritto nell'epoca decemvirale (Atti del convegno di diritto romano - Copanello 3-7 giugno 1984), Napoli, Ed. Scientifiche Italiane, 1988.

Lotte per la terra e per la casa a Roma, in SeRRAO, Feliciano, Legge e società nella repubblica romana 1, Napoli, Jovene, 1981.

SheRRATT, S.; SherRATt, A., The Growth of the Mediterranean Economy in the Early First Millenium B.C., in Word Archeology $24^{3}$ (1993), pp. 361-378.

SIHLER, Andrew L., New Comparative Grammar of Greek and Latin, New York, Oxford University, 1995.

SILVeIRA MARChI, Eduardo César, A Propriedade Horizontal no Direito Romano, 2. ed., São Paulo, Quartier Latin, 2003.

-----, Eduardo César, Guia de Metodologia Científica (Teses, Monografias e Artigos), Lecce, Edizioni del Grifo, 2002.

SiRKs, A. J. B., An Aspect of Archaic Roman Law: Auctoritas Tutoris, in Feldbrugge, Ferdinand Joseph Maria, The Law's Begginings, Leiden-Boston, Martinus Nijhoff, 2003, pp. 45-58.

SmITH, William, A Dictionary of Greek and Roman Antiquities, London, J. Murray, 1875.

SolazzI, Siro, Diritto ereditario romano I, Napoli, Jovene, 1932.

SOMmer, Ferdinand, Handbuch der Lateinischen Laut- und Formenlehre - Eine Einführung in das Sprachwissenschaftliche Studium des Lateins, Heidelberg, C. Winter, 1948.

SPIEGELBERG, Herbert, Gesetz und Sittengesetz - Strukturanalytische und historische Vorstudien zu einer gesetzfreien Ethik, Zürich, M. Niehans, 1935.

SPULER, Bertold (org.), Handbuch der Orientalistik, vol. $1^{3}$ - Orientalistisches Recht, Leiden/Köln, E. J. Brill, 1964.

StAedleR, Erich, Zum Rechtsbegriff der Augustischen auctoritas Mon. Ancyr. 34, in SZ 63 (1943), p. 384.

SteinKELLER, Piotr, Sale Documents of the Ur-III-Period, Stuttgart, F. Steiner, 1989.

SteINMETZER, Franz X., Über den Grundbesitz in Babylonien zur Kassitenzeit - Nach den sog. Grenzstein dargestellt, Leipzig, Heinrich, 1918. 
StuARt-Smith, Jane, Phonetics and Philology: Sound Change in Italic, London, Oxford University, 2004.

Sumner Maine, Henry, Études sur l'histoire du droit, Paris, E. Thorin, 1889.

SURINGAR, W. H. D., Historia critica scholiastarum latinorum I, Lugduni, Luchtmann, 1834.

TALAMANCA, Mario, Istituzioni di diritto romano, Milano, Giuffrè, 1990.

TAUBENSCHLAG, Rafael, Das römische Privatrecht zur Zeit Diokletians, in Opera minora I, Warsaw, Panstwowe Wydawnictwo Naukowe, 1959.

TÄUBLER, Eugen, Untersuchungen zur Geschichte des Decemvirats und der Zwölftafeln, Berlin, E. Ebering, 1921.

THORMANN, Karl Friedrich, Die doppelte ursprung der mancipatio - Ein Beitrag zur Erforschung des frührömischen Rechtes unter Mitberücksichtigung des nexum, München, Beck, 1943.

THULIN, Carl O, Die etruskische Disciplin III - Die Ritualbücher und zur Geschichte und Organisation der Haruspices, Darmstadt, Wissenschaftliche Buchgesellschaft, 1968.

TICHY, Eva, Gr. oíozıv, lat. uti und die Mittelzeile der Duenos-Inschrift, in Glotta 78 (2004), pp. 179-202.

TILL, Rudolf, Die Sprache Catos, Leipzig, Dieterich, 1935.

TORELLI, Mario, Archaic Rome between Latium and Etruria, in WALBANK, Frank William; Astin, A. E. (ed.), The Cambridge Ancient History VII - Part 2: The Rise of Rome to 220 B.C., Cambridge, Cambridge University, 2008.

Valeton, M. J., De templis Romanis, in Mnemosyne 25 (1897), pp. 93-144.

Vallat, François, The Most Ancient Scripts of Iran: The Current Situation, in World Archeology, $17^{3}$ (1986), pp. 335-347.

Vicco, Giambattista, Della costanza del giurisprudente, Napoli, Morano, 1861.

VINOGRAdOFF, Paul, Outlines of Historical Jurisprudence I (1920), reimpress., New Jersey, Lawbook Exchange, 1999.

Voegelin, Eric, Order and History II - The World of the Polis, Louisiana, Louisiana State University, 1957.

, The New Science of Politics, Chicago, University of Chicago, 1952.

VoIGT, Moritz, Das Civil- und Criminalrecht der XII Tafeln II, Leipzig, A. B. Liebeskind, 1883.

Von WrIGHT, Georg, Deontic Logic, in Mind 60 (jan. 1951), pp. 1-15.

pp. $136-143$. 
WACKERNAGEL, Jakob, Altindischen Grammatik II - Einleitung zur Wortlehre Nominalkomposition, Göttingen, Vanderhoek \& Ruprecht, 1905.

Wagenvoort, Hendrik, Princeps, in Philologus 91 (1936), pp. 206-322.

-, Profanus, profanare, in Mnemosyne $4^{2}$ (1949), p. 319-320.

-, Roman dynamism, Westport, Greenwood, 1976.

WALDE, Alois; HofmAnN, Johann Baptist, Lateinisches etymologisches Wörterbuch, $5^{\text {a }}$. ed., Heidelberg, C. Winter, 1982.

WALDE, Alois; PokoRnY, Julius, Vergleichendes Wörterbuch der indogermanischen Sprachen I, Berlin-Leipzig, Walter de Gruyter, 1930.

WALDSTEIN, Wolfgang; RAINER, Michael, Römische Rechtsgeschichte, 10. ${ }^{\text {a }}$ ed., München, Beck, 2005.

WaRD, Lorne H., Roman Population, Territory, Tribe, City, and Army Size from the Republic's Founding to the Veientane War, 509 B.C.-400 B.C, in The American Journal of Philology 111' (1990), pp. 5-39.

WARDE-FOWLER, W., The Original Meaning of the Word Sacer, in JRSt 1 (1957), pp. 57-63.

WARNKÖNIG, Léopold Auguste, Institutiones iuris Romani privati, in usum praelectionum academicarum vulgatae cum introd. in universam iurisprudentiam et in studium iuris romani, $4^{\mathrm{a}}$. ed., Bonna, A. Marcus, 1860.

Watson, Alan, Mancipatio and Transfer of Ownership, in Rome of the XII Tables Persons and Property, New Jersey, Princeton University, 1975. 100-105.

Clarendon, 1968.

WEBER, Max, Die römische Agrargeschichte in ihrer Bedeutung für das Staats- und Privatrecht (1891), reimpress., Tübingen, J. C. B. Mohr, 1986. , Wirtschaft und Gesellschaft, 5.a ed., Tübingen, Mohr Siebeck, 1980.

Wenger, Leopold, Die Quellen des römischen Rechts, Wien, A. Holzhausen, 1953. Miscellanea Fr. Ehrle II, Roma, 1924. (1949), pp. 88-90.

Westbrook, Raymond, Nature and Origins of the XII Tables, in SZ 105 (1988), pp. 74-121.

WeStRUP, Carl W., Introduction to Early Roman Law II - Joint Family and Family Property, Copenhagen-London, E. Munksgaard-Oxford University, 1934. 
Notes sur la sponsio et le nexum dans l'ancien droit romain - Le nouveau fragment des Institutes de Gaius, København, E. Munksgaard, 1947. , Propriété primitive, in RH 12 (1933), pp. 230-245.

WIEACKER, Franz, Entwicklungsstufen des römischen Eigentums, in WIEACKER, Franz, Vom römischen Recht - Zehn Versuche, 2. ${ }^{\text {a }}$ ed., Stuttgart, Koehler, 1961.

------------, lus e lex in Roma arcaica, in Scritti in onore di Antonio Guarino (=Sodalitas) 7 , pp. 3109-3110.

WINCKER, Hugo, Geschichte Babyloniens und Assyriens, Leipzig, E. Pfeiffer, 1882.

WissoWA, Georg, Religion und Kultus der Römer, 2. ${ }^{a}$ ed., München, Beck, 1912.

WitTgensteIn, Ludwig, Philosophische Bemerkungen - Aus dem Nachlaß herausgegeben von Rush Rhees, Oxford, Blackwell, 1964.

WolfF, Hans Julius, Verjährung von Ansprüchen nach attischem Recht, in ERANION PROS GEORGION S. MARIADAKHN (=Eranion in honorem Georgii S. Maridakis) I -

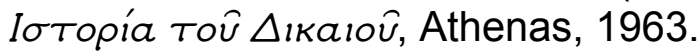

YARON, Reuven, Reflections on usucapio, in TR 192 (1967), pp. 191-229.

ZIMMERMAnN, Reinhard, The Law of Obligations: Roman Foundations of the Civilian Tradition, London, Clarendon, 1996.

ZLINSZKY, János, Legis actio sacramento in rem, in SZ 106 (1989), pp. 106-151.

Zocco-Rosa, A., Per Appius Claudius e per l'lus Flavianum, in SZ 33 (1912), pp. 491493. 


\section{Resumo}

A chamada regra do usus auctoritas, presente na Lei das XII tábuas, é apontada, desde Cujácio (séc. XVI), e daí em diante por muitos juristas, como sendo uma antiga norma sobre a garantia do vendedor - por meio de negócio formal, mancipatio - em caso de evicção; o próprio sentido do vocábulo auctoritas seria «garantia», ou mesmo «dever de prestar garantia», neste caso particular inseparável da mancipatio.

Mas o fragmento que traz essa regra - USUS AUCTORITAS FUNDI BIENNIUM EST[O] - nos foi transmitido por Cícero e (embora de forma já interpretada) Gaio; e estes a consideram uma espécie de antiga norma a respeito do usucapião (inicialmente apenas de imóveis). Outros juristas antigos e contemporâneos seguiram, em parte, essa interpretação original.

$\mathrm{O}$ trabalho pretende trazer novos argumentos em favor dessa exegese natural de Cícero e Gaio no sentido de que a dita regra versa sobre usucapião, mais especificamente sobre uma sua forma arcaica e bastante peculiar. Investiga-se o surgimento da propriedade imobiliária em Roma e suas peculiaridades: o sistema augural, quase religioso, de limitação do solo destinado, no início, a todo cidadão romano, conferido por meio de atos de adsignatio (concessão) pelo «estado» em formação, que detinha a auctoritas ou poder; a passagem da soberania das gentes pré-romanas aos Quirites; a gradual privatização - a atribuição dessa auctoritas coletiva e diretamente quiritária ao proprietário - dessas parcelas de terra e a fragmentação do solo pelo direito privado regulado pela Lei das XII tábuas, que confere autonomia (a auctoritas ou título) aos indíviduos e suas famílias.

Acrescenta-se uma breve análise lógica da regra e uma tentativa de a inserir no esquema geral do usucapião moderno. 


\section{Abstract}

The usus auctoritas rule from the Twelve Tables was conceived by Jacques Cujas (16th century AD), and many authors thereafter, as an ancient norm that established a warranty against eviction granted by the seller when transferring the ownership of the thing to the buyer through the performance of mancipatio. According to this view, the very word auctoritas is taken to mean "warranty", or else to imply an "obligation to give warranty", and is intrinsically associated with mancipatio.

But the fragment of the sources that state this rule - USUS AUCTORITAS FUNDI BIENNIUM EST[O] - were brough to us by Cicero and Gaius (the latter in the form of an interpretation of the norm), and both consider it to be an ancient Roman disposition that originally dealt with usucaption of immovable property only. To a certain extent, various ancient and modern jurists accept the latter interpretation.

The object of this thesis is to provide new arguments to support the more natural interpretation adopted by Cicero and Gaius, i.e., that the rule in question deals specifically with an archaic and peculiar form of usucapio. The present work analyzes the emergence of private ownership of immovable property in Rome and its peculiarities: the quasi-religious augural system of land apportionment adopted by the fledging Roman state to assign a lot of land to every Roman citizen through the performance of acts of adsignatio (allotment); the sovereignty transferred by the pre-Roman gentes to the Quirites; the process by which land plots were gradually privatized and landowners acquired this once collective and "quiritarian" auctoritas, and the resulting land apportionment caused by the application of rules of private law based on the Twelve Tables conferring autonomy (auctoritas or title) to individuals and their families.

In the final lines, an attempt is made to provide a logical analysis of the rule and to place it within the general conceptual framework of modern usucaption. 


\section{Résumé}

La règle de l'usus auctoritas, présente dans la Loi des XII Tables, est considerée, depuis Cujas (siècle XVI) et désormais par plusieurs juristes, comme une ancienne norme sur la garantie du vendeur - par l'affaire formelle, mancipatio - dans le cas d'éviction; le sens du mot auctoritas serait "garantie", ou même "devoir de garantie", dans ce cas particulier inséparable de la mancipatio. Mais le fragmente qui possède cette règle - USUS AUCTORITAS FUNDI BIENNIUM EST(O) - nous a été trasmis par Ciceron et (bien que de façon

déja intrepretée) Gaius, e tous le deux la considèrent comme une sorte de anciènne norme sur l'usucapion (iniciallement seule pour des biens imòbles). D'autres juristes anciens e contemporains suivent, en partie, cette interprétation originelle.

Ce travail veut apporter des nouveaux arguments pour cette intreprétation naturelle du text de Ciceron et de Gaius dans le sens de que cette règle s'agit sur l'usucaption, em particulier sur une forme archaïque et très specièle. On recherche l'émergence de la proprieté imobilière à Rome et ses particularités: le sistème augural, presque religieux, de limitation de terre destinée, au début, à chaque citoyen romain, achevé par des actes de adsignatio (concession) par l'"état" dans sa formation, qui avait l'autoritas ou pouvoir, le passage de la soberanie des gentes pré-romaines aux Quirites; la graduelle privatization l'attribuition de cette auctoritas colective e directement quiritaire au proprietaire - des ces parcelles de terre et la fragmentation du sol par le droit privé regulé par la Loi des XII Tables qui donne autonomie (l'auctoritas ou tître) aux individus et ses familles.

On ajoute une brève analyse logique de la règle et un essai de l'insérer dans le plan général du usucapion moderne. 